\title{
Superblock Integrated Safety Management System Description
}

\author{
J.M. Mintz, A.B. Copeland, J.D. Mapes, J.A. Sefcik
}

\section{October 1, 1999}

U.S. Department of Energy

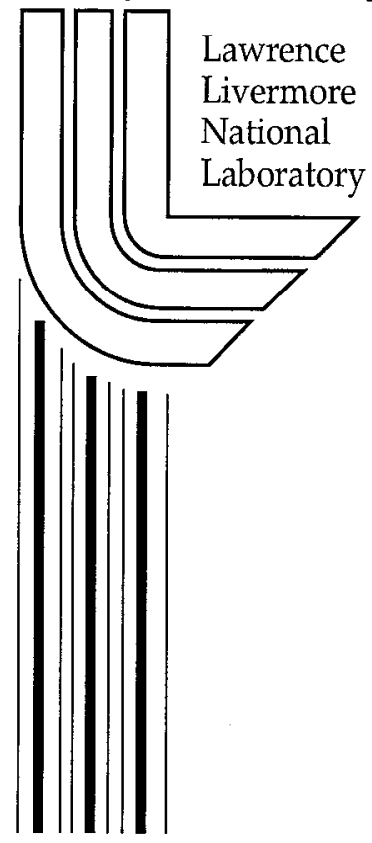




\section{DISCLAIMER}

This document was prepared as an account of work sponsored by an agency of the United States Government. Neither the United States Government nor the University of California nor any of their employees, makes any warranty, express or implied, or assumes any legal liability or responsibility for the accuracy, completeness, or usefulness of any information, apparatus, product, or process disclosed, or represents that its use would not infringe privately owned rights. Reference herein to any specific commercial product, process, or service by trade name, trademark, manufacturer, or otherwise, does not necessarily constitute or imply its endorsement, recommendation, or favoring by the United States Government or the University of California. The views and opinions of authors expressed herein do not necessarily state or reflect those of the United States Government or the University of California, and shall not be used for advertising or product endorsement purposes.

Work performed under the auspices of the U. S. Department of Energy by the University of California Lawrence Livermore National Laboratory under Contract W-7405-Eng-48. 
UCRL-AR-131934

Rev. 2

Defense \& Nuclear Technologies Directorate

\title{
Superblock Integrated Safety Management System Description
}

\author{
October 1999
}

Rev. 2

Reviewed by:
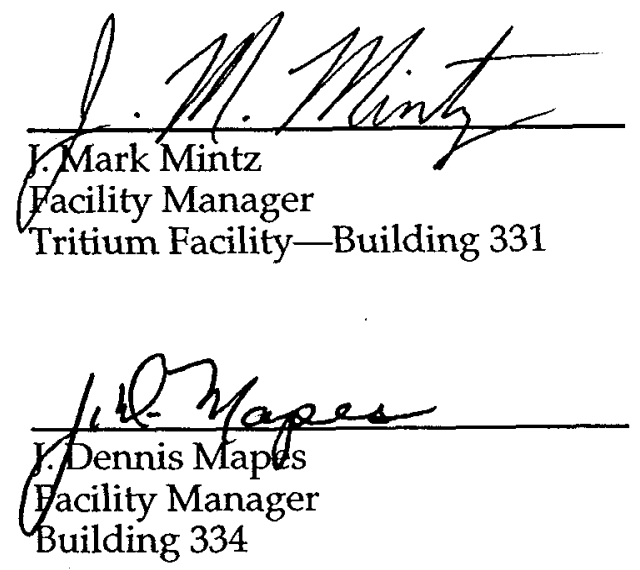

Approved by:

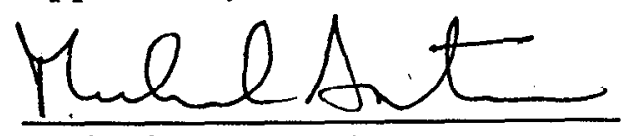

Michael R. Anastasio

Associate Director

Defense \& Nuclear Technologies
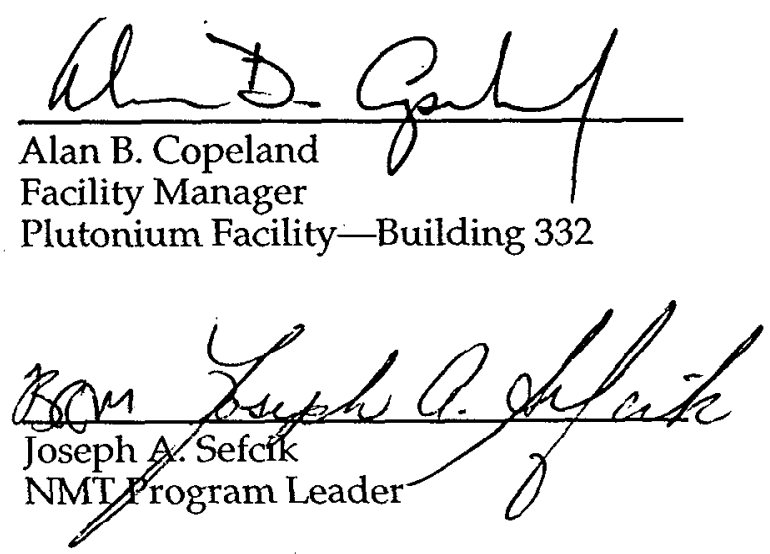

Approved by:

James M. Turner

Manager

Oakland Operations Office ?

Department of Energy 


\section{Table of Contents}

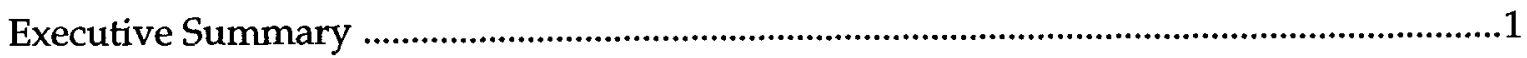

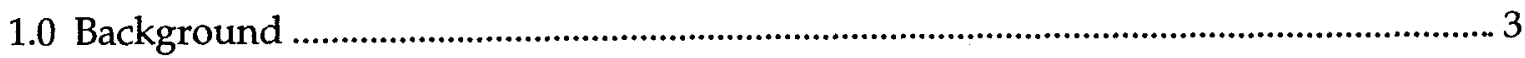

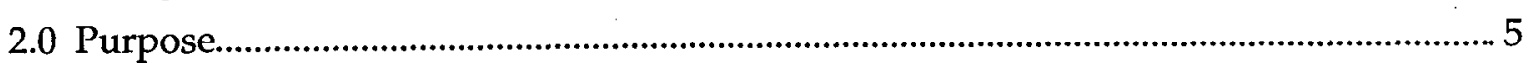

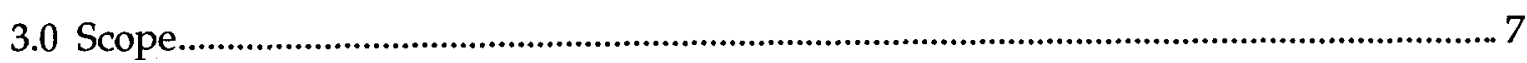

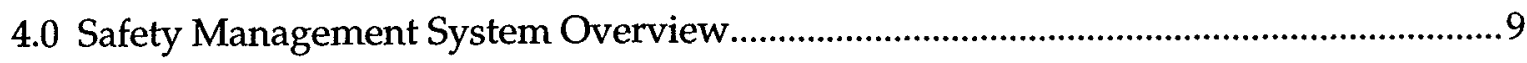

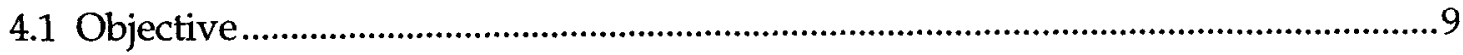

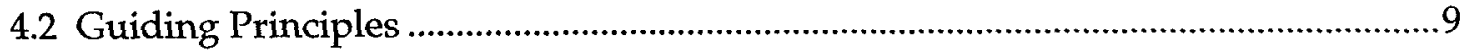

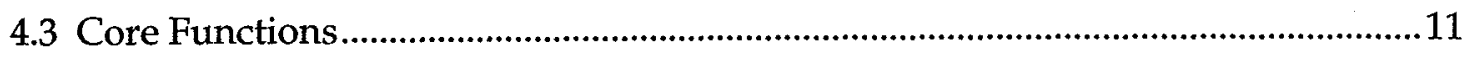

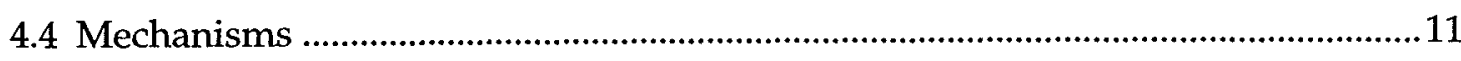

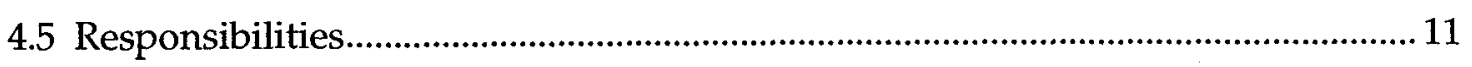

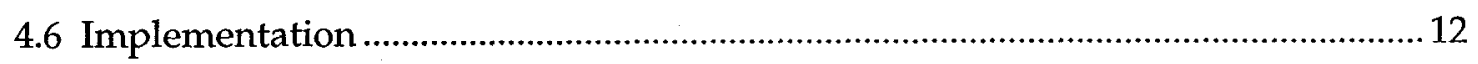

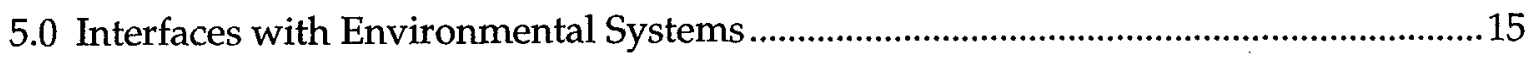

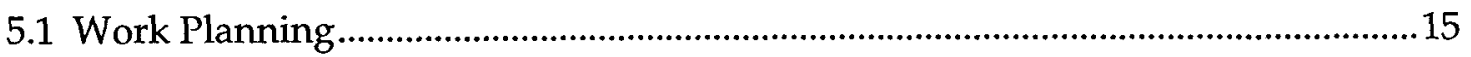

5.2 Spill and Release Reporting................................................................................. 16

5.3 Waste Minimization and Pollution Prevention ................................................... 16

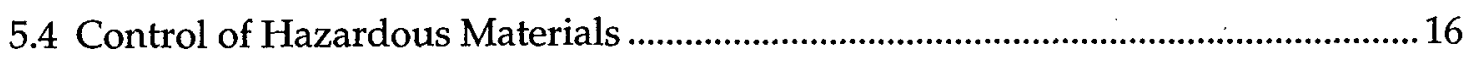

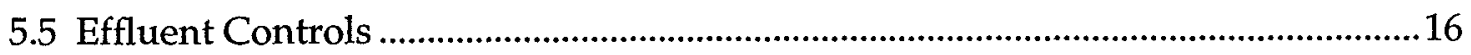

5.6 Management of Hazardous, Radioactive, and Mixed Waste .................................. 17

5.7 Interfaces with the Environmental Protection Department ...................................18

6.0 Safety Management System Mechanisms .......................................................................... 21

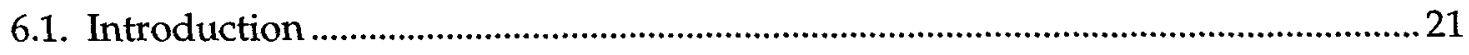

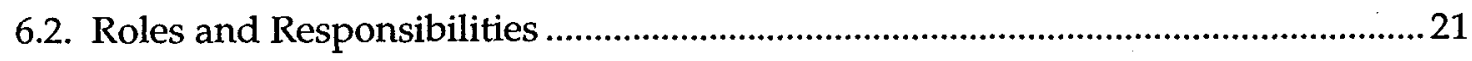

6.2.1 Line Management Responsibilities for Safety ............................................21

6.2.2 Clear Roles and Responsibilities ..................................................................22

6.2.3 Competence Commensurate with Responsibilities..................................... 24

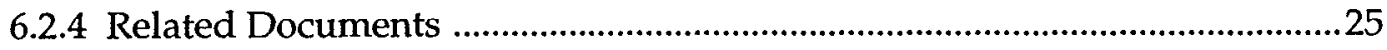

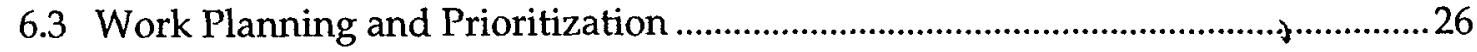

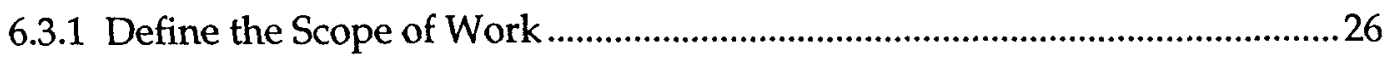

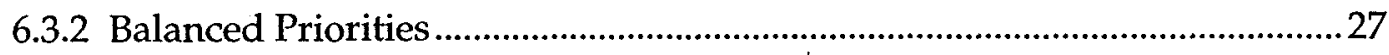

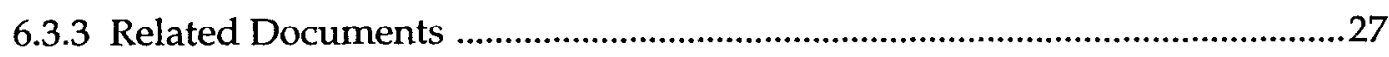

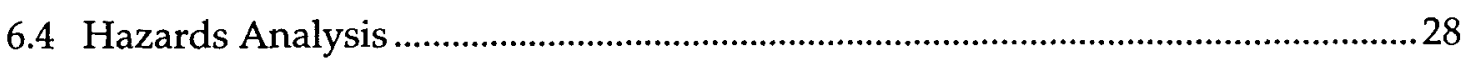

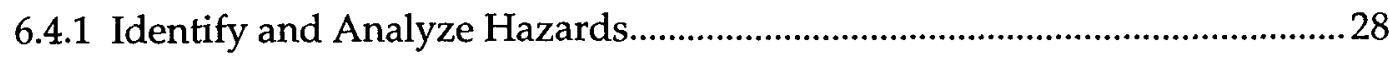

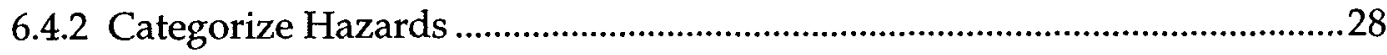




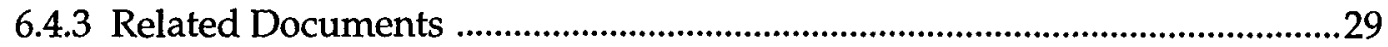

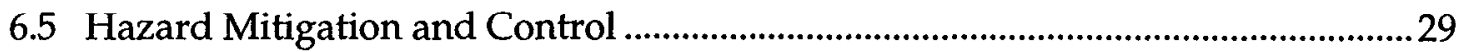

6.5.1 Develop and Implement Hazard Controls.....................................................29

6.5.2 Identification of Safety Standards and Requirements....................................30

6.5.3 Hazard Controls Tailored to Work Being Performed ...................................30

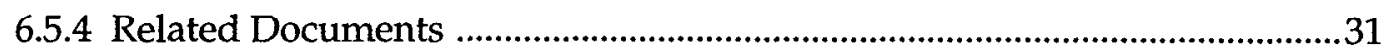

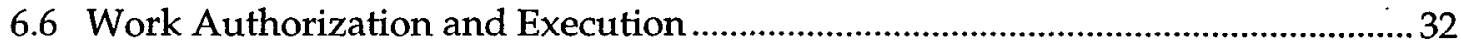

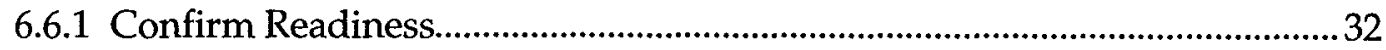

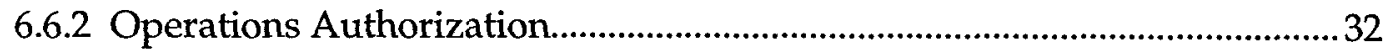

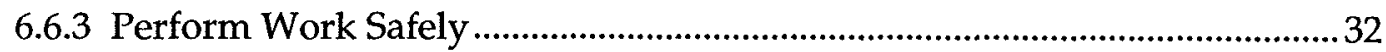

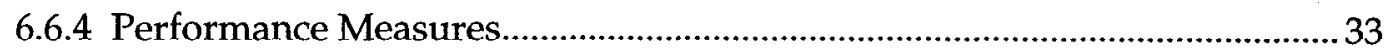

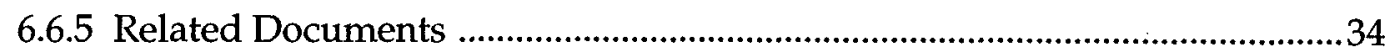

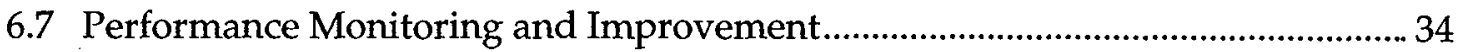

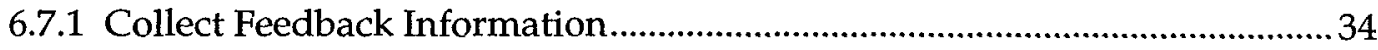

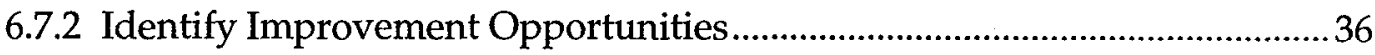

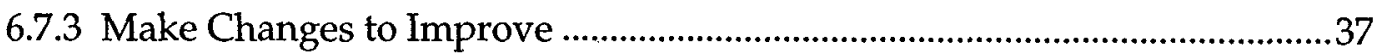

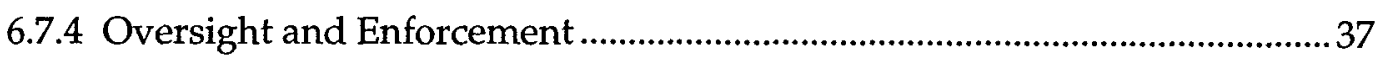

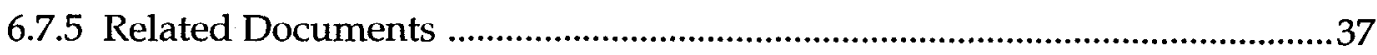

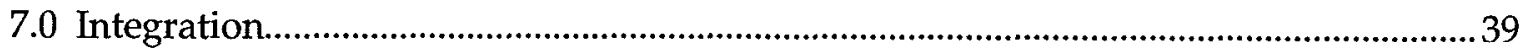

7.1 Integration of Core Functions and Guiding Principles .........................................39

7.2 Integration of Core Functions Throughout Organizational Levels ....................... 41

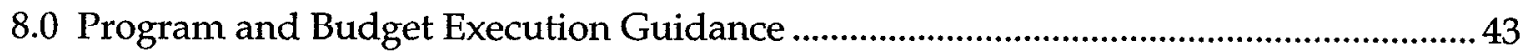

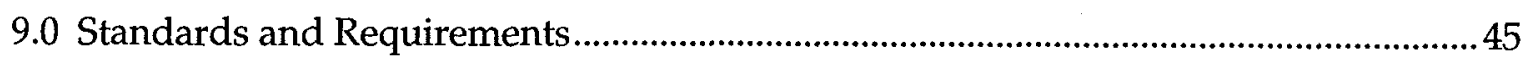

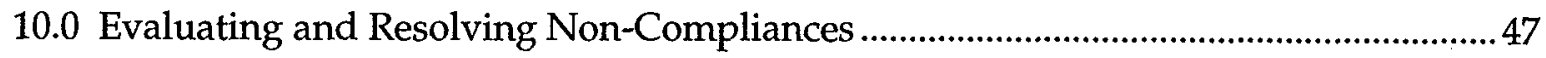

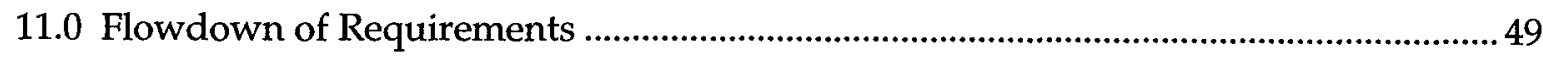

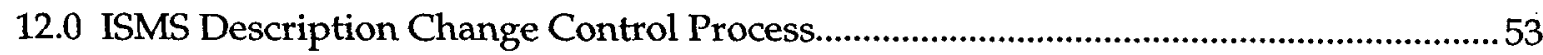

13.0 Reconciliation of Superblock ISMS with Site-wide ISMS............................................. 55

14.0 Implementation Tasks, Schedule, and Milestones .....................................................57

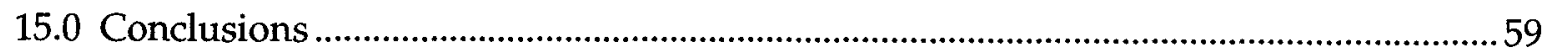

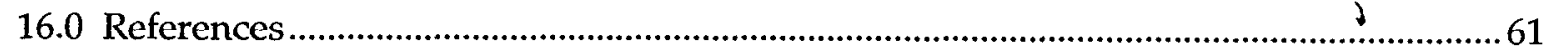

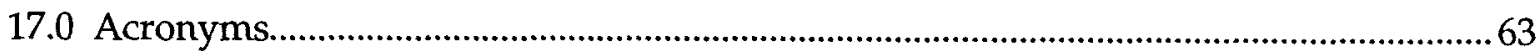

Appendix A. Integrated Safety Management System (ISMS) for Building 332 ................A-1

Appendix B. Integrated Safety Management System (ISMS) for Building 331 ............... B-1

Appendix C. Integrated Safety Management System (ISMS) for Building 334............... C-1 


\section{Executive Summary}

This document presents the Integrated Safety Management System (ISMS) Description for the Superblock non-reactor nuclear facilities-Tritium Facility (Building 331), Plutonium Facility (Building 332), and Building 334-at the Lawrence Livermore National Laboratory. Building 332 is a Nuclear Hazard Category 2 facility, while Buildings 331 and 334 are Category 3 facilities in accordance with DOE STD-1027, DOE STD-3009, and DOE Order 5480.23. In implementing the Superblock ISMS Description, a graded approach is used-the Category 2 nuclear facility description provides more detail than those for the Category 3 nuclear facilities.

The Superblock ISMS Description, prepared in accordance with the DOE/OAK Guidance Letter of August 18, 1998, on preparation, content, review, and approval of the LLNL Descriptions, is to satisfy the conditions of DEAR clauses 48 CFR 970.5204-2 and 48 CFR 970.5204-78 in Contract No. W-7405-ENG-48. Also, this document fulfills the intent of DOE Policy P450.4 and is consistent with guidance provided by DOE G 450.4-1.

Elements of the Superblock ISMS include the five core functions and seven guiding principles, as defined in DOE Policy P450.4 and described further in Section 4 of the LLNL ISM System Description (Version 2.0, dated 10/1/99).

This Superblock ISMS Description consists of the following topics:

- Background-Presents information on how the ISMS has been developed.

- Purpose-Describes the reasons for the development of this document.

- Scope-Defines the boundaries and areas covered by this document and to which it applies.

- System Overview-Provides an overview of the Superblock ISMS.

- Environmental Systems-Addresses interfaces between safety requirements and environmental systems.

- Safety Management System Mechanisms-Discusses how the seven guiding principles and the five core functions are implemented and performed in the Superblock.

- Integration-Explains how the Superblock ISMS is systematically integrated into management and work practices at all organizational levels, including,individual activity.

- Program and Budget Execution Guidance--Describes how line managers make informed decisions on scope, schedule, and budget issues in accordance with agreed-upon safety performance objectives, measures, and commitments.

- Standards and Requirements-Describes how and what standards are selected and the process of incorporating selected standards into safety documents required for the performance of work at the Superblock. 
- Evaluating and Resolving Non-Compliances-Discusses the process of evaluating and resolving non-compliance issues.

- Flowdown of Requirements-Presents a flowdown relationship of requirements from the institution to Superblock level, to facility level, to the individual activity level.

- ISMS Change Control Process Description-Details the steps required to change the Superblock ISMS Description, including its appendices.

- Process for Reconciliation of Superblock Nuclear Facilities ISMS with Site-wide ISMS -Describes a process for reconciling discrepancies between the Superblock ISMS and the site-wide ISMS.

- Implementation Tasks, Schedule, and Milestones-Identifies implementation tasks and their schedule and milestones with respect to non-compliance issues and any discrepancies between the Superblock ISMS and the site-wide ISMS.

- Conclusions-Summarizes the implementation status of the Superblock ISMS Description.

- References.

- Appendix A-Presents the B332 ISMS Description, addressing document Sections $6.0,7.0,8.0,9.0,10.0,11.0$, and 14.0 in detail.

- Appendix B-Presents the B331 ISMS Description, addressing document Sections $6.0,7.0,9.0,10.0,11.0$, and 14.0 in detail.

- Appendix C-Presents the B334 ISMS Description, addressing document Sections $6.0,7.0,9.0,10.0,11.0$, and 14.0 in detail. 


\subsection{Background}

Further to the LLNL ISM System Description (Version 2.0, dated October 1, 1999) and the DNT ISMS Implementation Plan, this Superblock Integrated Safety Management System Description serves as a road map, describing the information and processes to systematically integrate safety into management and work practices at all levels of the LLNL Superblock (i.e., Superblock, facility, activity) so that missions are safely accomplished while protecting the public, the workers, and the environment.

The Superblock ISMS Description, prepared in accordance with the DOE/OAK Guidance Letter of August 18, 1998, on preparation, content, review, and approval of the LLNL Descriptions, is to satisfy the conditions of DEAR clauses 48 CFR 970.5204-2 and 48 CFR 970.5204-78 in Contract No. W-7405-ENG-48. Also, this document fulfills the intent of DOE Policy P450.4 and is consistent with guidance provided by DOE G 450.4-1. DOE/OAK comments of February 24, 1999 (for the Superblock and Appendix A portions), March 8, 1999 (for Appendices B and C), and August 24, 1999, have been addressed in this revision. Likewise, comments from the September 1999 ISMS Phase I and II Verification have been incorporated herein. 
This page intentionally left blank. 


\subsection{Purpose}

The purpose of this Superblock ISMS Description is to document a formal, organized system whereby workers at the Superblock plan, perform, assess, and improve the safe conduct of work, as promulgated by DOE Policy P 450.4, "Safety Management System Policy." Essentially, the description is a road map that provides an integrated statement of how the various organizations, procedures, and processes come together as an ISMS.

Also, this Description satisfies the documentation requirements consistent with the LLNL ISM System Description and with Clause 6.7 - DEAR 970.5204-2, "Integration of Environment, Safety, and Health into Planning and Execution" of Contract No. W-7405ENG-48 between the Regents of the University of California and the U.S. Department of Energy. 
This page intentionally left blank. 


\subsection{Scope}

The Superblock ISMS described herein applies to work performed at the Superblock by resident facility workers, program users, personnel from supporting organizations, and subcontractors in the three non-reactor nuclear facilities under separate Authorization Agreements with DOE/OAK. The main body of this Description provides information on safety practices throughout the Superblock. Appendices to this document provide specific practices of the three nuclear facilities within this area. Appendix A pertains to Building 332; Appendices B and C pertain to Buildings 331 and 334, respectively. Significant coordination occurs among facility management and Safeguards and Security (S\&S) personnel to assure their activities are accomplished within the authorization bases. For non-routine exercises, performance testing, etc., that may affect, or be affected by, facility and yard activities, S\&S personnel follow Superblock safety procedures. See Section 6.0, Superblock Safety Management System Mechanisms, for more discussion.

The Superblock is a special-access area with around-the-clock protection for Special Nuclear Material (SNM) by the Laboratory's Protective Service Force, which is included within S\&S activities. The Superblock is isolated from the adjacent LLNL "Limited Access Area" and "Controlled Areas" by chain-link fences with secure access points. Figure 1 is a diagram of the Superblock.

The Superblock consists of three non-reactor nuclear facilities-Building 331, Building 332, and Building 334. Building 332, the Plutonium Facility, is designated as a Nuclear Hazard Category 2 facility. Building 331, the Tritium Facility, is designated as a Category 3 nuclear facility, as is Building 334. Each of the three facilities has an assigned Facility Manager (FM). Building 335 is a support facility for equipment and records storage, as well as office space. All references to Building 332 include Building 335 . Buildings 336, 337, and 338 are security-related buildings.

The Plutonium Facility's mission includes the handling and storage of plutonium needed for national security research and development. The Tritium Facility offers state-of-art, low-level tritium research and development capability, with a mission focused on tritium system design, tritium recovery and decontamination projects, and maintaining and nurturing tritium expertise at LLNL. The Building 334 mission includes support of a variety of engineering tests and performance of intrinsic radiation measurements. 


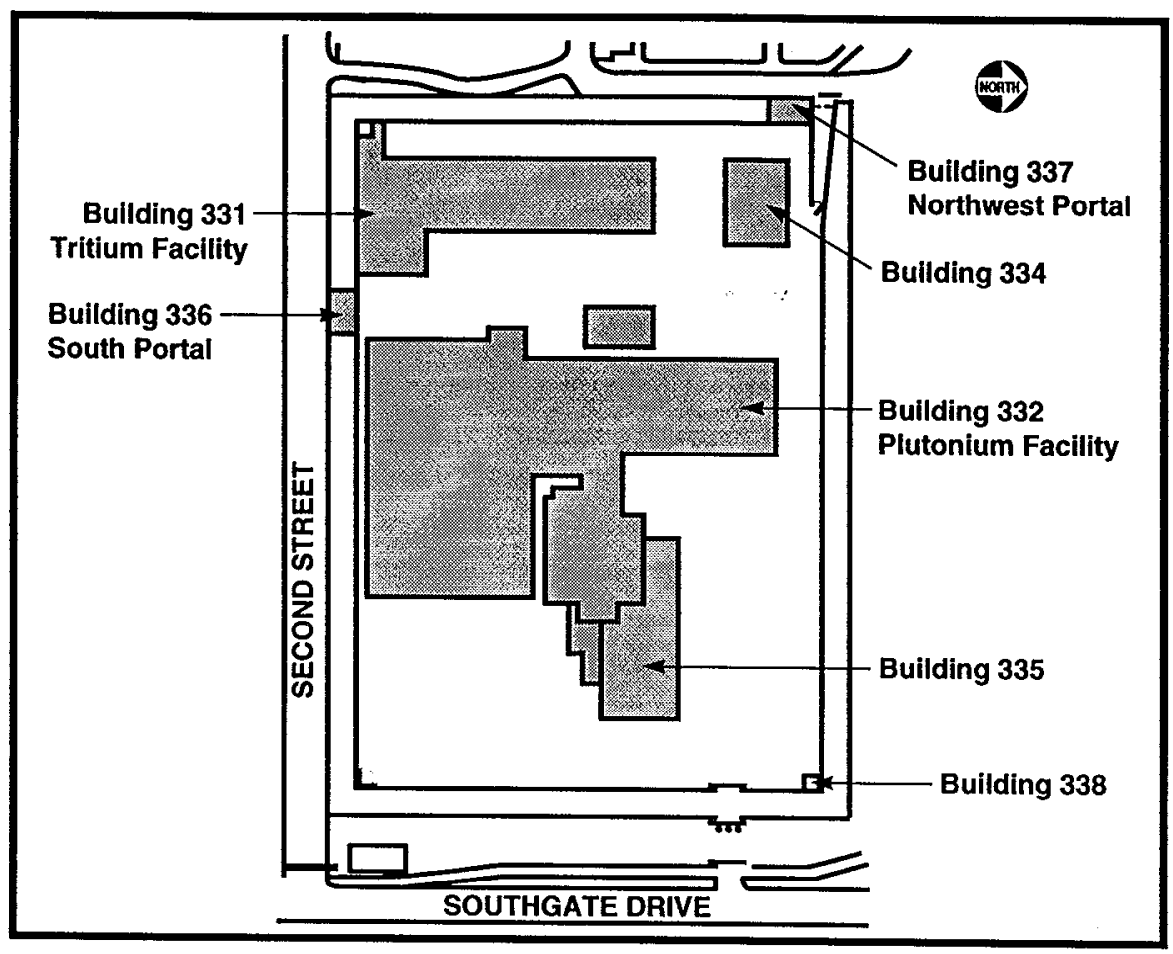

Figure 1. Superblock facilities. 


\subsection{Safety Management System Overview}

The safety management system described in DOE Policy P 450.4, "Safety Management System Policy," consists of six primary components: (1) objective, (2) guiding principles, (3) core functions, (4) mechanisms, (5) responsibilities, and (6) implementation. The objective, principles, and functions components are consistently implemented throughout the DOE complex. The mechanisms, responsibilities, and implementation components are established for all work at the Superblock and vary based on the nature and hazard of work being performed. A brief description of the components is presented in this section, and detailed discussions are presented in Sections 6.0 and 7.0.

\subsection{Objective}

The objective of the Superblock ISMS is to systematically integrate safety into Superblock management and work practices at three levels (i.e., Superblock, facility, and activity) so that missions are accomplished while protecting the public, the workers, and the environment. Note that the activity level includes both programmatic work and facility-related maintenance activities.

\subsection{Guiding Principles}

The seven guiding principles are the fundamental policies that guide Superblock actions from development of safety directives to performance of work. The Lawrence Livermore National Laboratory Director is responsible for the conduct of activities at LLNL. The Director assigns the responsibility to operate facilities to the Associate Directors (AD). The Director has assigned the Superblock facilities to the AD for Defense and Nuclear Technologies (DNT). The AD for DNT holds the Nuclear Materials Technology (NMT) Program Leader responsible for the conduct of activities in the Superblock facilities. The NMT Program Leader, through the NMT Deputy for Facility Operations, assigns to FMs the responsibility for facility-related activities, particularly facility support, such as surveillance and maintenance of building safety systems. The NMT Program Leader has been assigned the responsibility to integrate safety management into the facility and programmatic activities conducted in the Superblock. The NMT Program Leader holds the NMT Deputy for Program Operations responsible for integrating safety management into programmatic activities. Specific boundaries between facility and programmatic areas are defined, and workers are trained to recognize them.

1. Line Management Responsibilities for Safety. Line management is directly responsible for the protection of the public, the worker, and the environment as described in the LLNL System Description, Section 6.2.3. In the Superblock specifically, NMTP management is responsible for integrating ES\&H into work and for ensuring active communication up and down the management line and with the workforce. The Nuclear Materials Technology Program Management Plan (UCRL-AR-135456) identifies relevant program and facility personnel and assigns responsibilities. 
2. Clear Roles and Responsibilities. Clear and unambiguous lines of authority and responsibility for ensuring safety are established and maintained at all organizational levels. At the Superblock, this principle is manifested in various safety documents, at a minimum in the Facility Safety Plans (FSPs) for all operations within the facility. Operational Safety Plans (OSPs) list the individuals responsible for safe operation of the activity covered in the OSP. The NMTP Management Plan at the Program level defines the Superblock responsibilities and augments the safety standards and requirements at the site level as well as facility and activity levels. It requires a current listing of line management responsibilities, from the worker to the Associate Director, by workstation and operations functions as detailed in Integrated Safety Management System Line Responsibilities (UCRL-AR-135803).

3. Competence Commensurate with Responsibilities. Personnel possess the experience, knowledge, skills, and abilities that are necessary to discharge their responsibilitics. In the Superblock specifically, NMT management and the involved Laboratory payroll managers ensure that the appropriate depth and breadth of technical talent in ES\&H is available and that the Laboratory has in place the means for periodically evaluating competencies, which include experience, training, and fitness for duty. Initial qualifications required of candidates are established by the responsible supervisor in job posting descriptions. These qualifications are reviewed and approved by the FM prior to release to the LLNL recruiting authority. Special training is required of workers with unescorted access into the Radioactive Materials Area (RMA), as defined by the NMTP Training Manager in the Training Plans for Buildings 331 and 332, and in the Training Implementation Matrix (TIM) for Building 334. Training to Radiation Zone Worker criteria is required for unescorted RMA access in Building 332. Personnel performing support functions, and subcontractors brought into the facilities for specific work, will be trained depending on the hazards of their tasks. All admittance into the RMA includes at least a safety and security awareness video prior to entry. See also Section 6.2.3, herein.

4. Balanced Priorities. Resources for the Superblock are effectively allocated to address safety, programmatic, and operational considerations. Protecting the public, the workers, and the environment is a prerequisite whenever activities are planned and performed.

5. Identification of Safety Standards and Requirements. Before the work is performed, the associated hazards are identified and evaluated against an agreed-upon set of safety standards and requirements, established in Appendix G of the DOE/UC Contract 48 , that provides adequate assurance that the public, the workers, and the environment are protected from adverse consequences. These safety standards and requirements are implemented through the LLNL Environmental, Safety and Health Manual (ES\&HM) and facility and programmatic implementing plans and procedures such as FSPs and OSPs.

6. Hazard Controls Tailored to Work Being Performed. Administrative and engineering controls to prevent and mitigate hazards are tailored specifically to the work being performed and associated hazards. The Superblock management, facility staff, program users, workers, and supporting organizations recognize that 
tailoring requires judgment to be exercised at the Superblock, facility, and activity levels.

7. Operations Authorization. The conditions and requirements to be satisfied for operations to be initiated and conducted are clearly established and agreedupon. Each Superblock facility has an Authorization Agreement with DOE/OAK. At the facility level, the new work authorization process is defined in the facility Work Control Manual. At the activity level, work authorization may include Work Permits, OSPs, and daily scheduling.

\subsection{Core Functions}

The five core safety management functions provide the necessary structure (as essential to planning and performing hazardous work safely) for any Superblock work activity that could potentially affect the public, the worker, and the environment. The functions are listed in the following and illustrated in Figure 2.

1. Define the Scope of Work.

2. Analyze the Hazards.

3. Develop and Implement Hazard Controls.

4. Perform Work within Controls.

5. Provide Feedback and Continuous Improvements.

\subsection{Mechanisms}

Mechanisms are the means by which the safety management functions are implemented. Policies, manuals, plans, procedures, and reports are all mechanisms used at the Superblock for implementing the ISMS. Specific mechanisms used by the Superblock to perform work safely are outlined in Section 6.0, Superblock Safety Management System Mechanisms. Also, the mechanisms as described in the Appendices vary from facility to facility and from activity to activity based on the hazards and the work being performed.

\subsection{Responsibilities}

Clear lines of responsibility within the Superblock are paramount to effective safety management. The responsibilities of the NMT Program Leader and other line management are detailed in Section 6.2.1. The responsibilities of individual Superblock FMs and facility workers are documented in the Appendices. The NMTP Management Plan provides additional information on responsibilities of Superblock management and staff. 


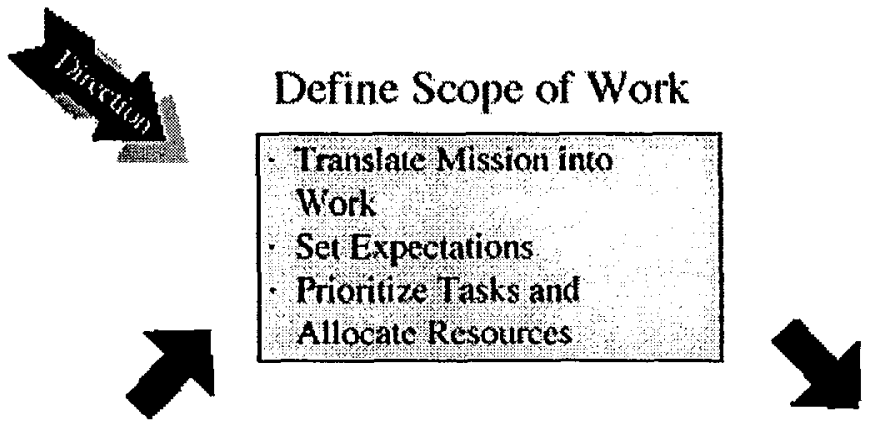

Feedback/Improvement
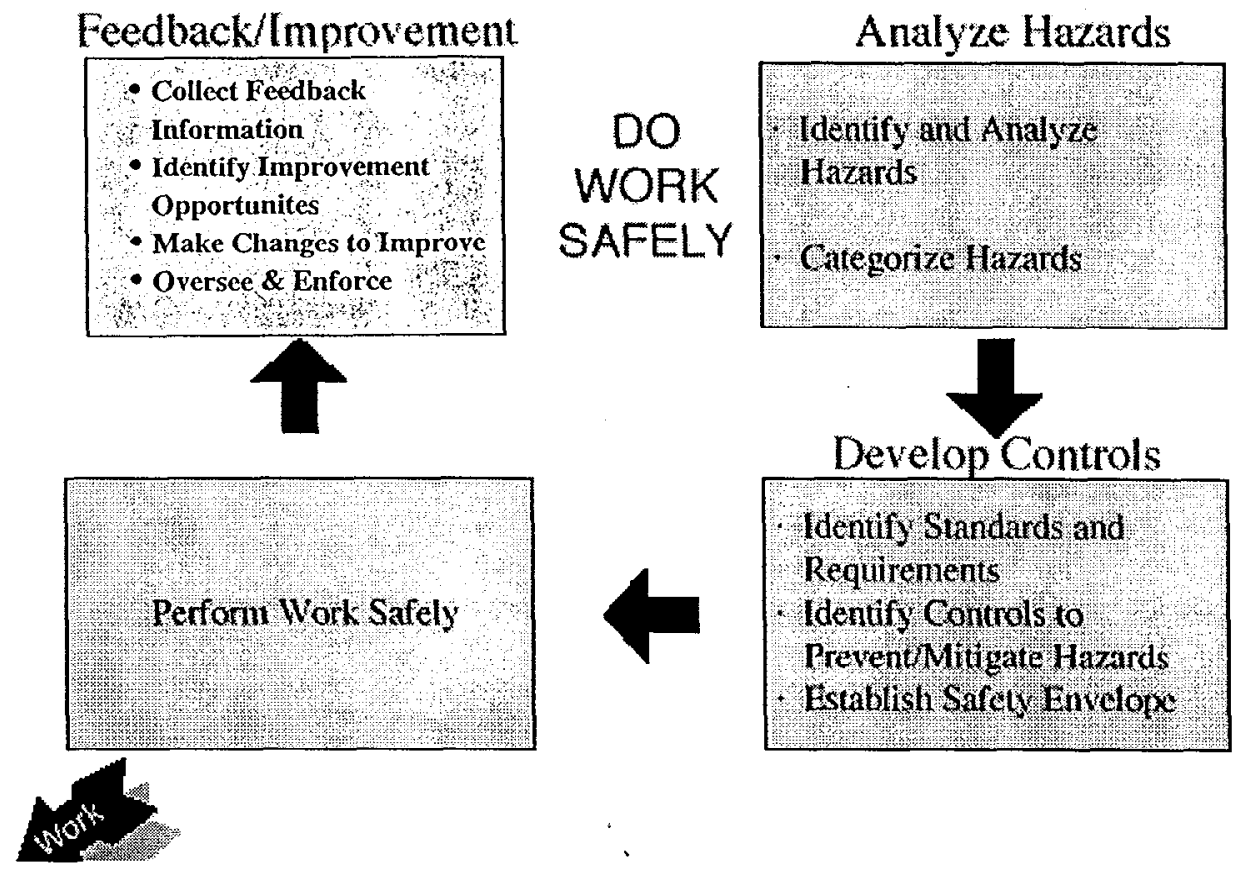

,

Figure 2. The five core safety management functions.

\subsection{Implementation}

The strategy for implementing ISMS at the Superblock is to comply with or adapt policies, programs, and procedures from the institutional level, the directorate level, and the facility level, as appropriate. This implementation includes specific instances of work definition and planning, hazards identifications and analysis, definition and implementation of hazard control, performance of work, developing and implementing operating plans, and assessing performance for improvements. These steps apply to all activities, facility-related as well as programmatic and S\&S, and implementation includes all participants, from the worker to the manager and up through the chain of responsibility, eventually to the sign-off by the responsible $A D$. For issues relating to the Authorization Basis, DOE/OAK may be required to sign off. For example, strict compliance to the Unreviewed Safety Question (USQ) process (see Sections 6.3.1 and 6.4.1 and the appendices for more information) is mandatory. A positive USQ would require DOE/OAK approval to accept risk for a particular activity. 
Authority levels for the adaptation of policies, programs, and procedures follows from the ES\&HM, Volume 1, Part 2, LLNL Exemption Process, which provides for written authority to deviate from a requirement or standard. See also the discussion on roles and responsibilities in Section 6.0. As stated there, the AD responsible for operating and maintaining the facility has final review and approval authority for all policies, programs, and procedures in his/her directorate. By way of the NMT Program Leader and his deputies, the AD assigns the FMs' responsibilities for ES\&H compliance within their facilities. 
This page intentionally left blank. 


\subsection{Interfaces with Environmental Systems}

The primary environmental concerns in the Superblock are:

- Waste minimization and pollution prevention (WMPP).

- Hazardous material controls as they relate to waste generation, chemical inventory management, and release of hazardous materials to the environment.

- Management of hazardous, radioactive, and mixed wastes.

- Compliance with environmental regulations.

\subsection{Work Planning}

Environmental concerns must be identified before starting new operations in the Superblock to ensure compliance with environmental regulations, identify disposal options for wastes generated, and avoid possible harm to the environment and/or costly disruption in programmatic activities that result from regulatory noncompliance. The 1992 Final Environmental Impact Statements and Environmental Impact Report for Continued Operation of Lawrence Livermore National Laboratory and Sandia National Laboratories, Livermore (1992 Site-wide EIS/EIR) and the Environmental Impact Report Addendum for the Continued Operation of Lawrence Livermore National Laboratory (1999 EIR Addendum) have assessed and documented actual or potential environmental consequences deriving from the Laboratory, including the Superblock facilities, in accordance with the National Environmental Policy and California Environmental Quality Acts. Planning is essential because several months are required to prepare, review, and obtain agency approval for environmental permits before initiating a new operation. Also, this planning will ensure that facility workers who will be packaging, handling, and disposing of the waste will be able to do so safely with foreknowledge of the materials.

Additionally, planning and review by Environmental Protection representatives of new operations generating hazardous, radioactive, and mixed waste are essential to ensure that there are appropriate disposal options for the wastes generated. In the case of radioactive and mixed wastes, completion of a Process Knowledge Evaluation (PKE) form ensures that these wastes will be accepted at established radioactive waste disposal sites and that no uncharacterized waste will accumulate in the Superblock facilities or the LLNL Hazardous Waste Management facilities. Preconstruction Site Evaluations are essential for the planning of construction projects within the Superblock where soil, asphalt, and/or concrete will be excavated, redistributing potentially contaminated materials in the environment and for the safe management of excess soil and asphalt and concrete rubble. The Preconstruction Site Evaluations also protect worker health and safety by determining if there is a known or suspected hazardous or radioactive contamination in the area to be excavated. 


\subsection{Spill and Release Reporting}

Any spill or accidental release of radioactive or hazardous materials in the Superblock, either in a laboratory or to the environment, shall be reported to the respective FM, who will follow the Defense \& Nuclear Technologies Occurrence Reporting Protocol (January 1996 or latest version) and inform the ES\&H Team for the determination of any reporting requirements to any outside regulatory agencies. ES\&H Team members have action plans in place and are trained to safely respond with protective and containment equipment to any but the most serious accidents. Additionally, LLNL's considerable Emergency Services capabilities for major accidents and treatment are available if needed. All workers are empowered to stop unsafe activities and are trained in response and communication in case of accidents.

\subsection{Waste Minimization and Pollution Prevention}

Waste minimization and pollution prevention (WMPP) is a vital facility and program responsibility. Each Superblock FM is responsible for ensuring that WMPP measures have been implemented to the maximum extent economically and technically practicable. Each Superblock FM is also responsible for adhering to Defense \& Nuclear Technologies' (DNT) Waste Minimization and Pollution Prevention Plan, DNT-WMPP.2, dated October 1997. At a minimum, the FM and program managers shall:

- Assess materials used in the work area and characterize all waste streams for hazardous, transuranic (TRU), mixed, and low-level waste (LLW) constituents.

- Ensure that waste stream information is included in each operational safety plan (OSP) and PKE form.

\subsection{Control of Hazardous Materials}

The following environmental controls for hazardous materials are required:

- A facility Health and Safety (H\&S) Technician and the Hazardous Waste Management Field Technician (HWMFT) must be contacted by the responsible individual for assistance before transferring hazardous chemicals or radioactive materials outside the facility for reuse by others or for disposal as hazardous or radioactive waste. Proper characterization paperwork is to be provided prior to removal of the waste from the facility. All persons who might conceivably generate waste are required to be trained in the documentation requirements and handling procedures.

- Personnel vacating space in each Superblock facility are responsible for properly disposing of hazardous chemicals and/or radioactive materials in their work area in accordance with the ES\&HM, the LLNL ChemTrack program, and the Laboratory's Waste Certification Program plans and implementing procedures.

\subsection{Effluent Controls}

For Building 332, air and inert gases used in glovebox operations and room air from the RMA are vented to the atmosphere by separate glovebox and room exhaust ventilation 
systems. Each system incorporates dual-stage high-efficiency particulate air (HEPA) filters to minimize the emission of radioactive particulates to the atmosphere. Passive air samplers (PASs) and continuous air monitors (CAMs) are installed in the exhaust ducts downstream of the HEPA filters. The B334 exhaust ventilation system is equipped with HEPA filters. However, because of the nature of the work in B334, no radioactive emissions monitoring is required downstream of the IIEPA filters.

Because HEPA filters do not capture radioactive gases, operations in B331 that use or generate radioactive gases or vapors require radioactive emissions monitoring and review and approval by the FM to ensure compliance with the National Emission Standards for Hazardous Air Pollutants (NESHAPS).

Air emission sources for operations must be identified and evaluated to determine applicable Bay Area Air Quality Management District (BAAQMD) requirements. Emission sources, including boilers and emergency power generators, in B331 are exempt from BAAQMD permitting requirements. Boilers and glovebox workstations in B332 are exempt from BAAQMD permitting requirements. However, machining operations in $\mathrm{B} 332$ that use solvents have been issued "Permits to Operate" from the BAAQMD, as have emergency power generators in B332 (three units) and B331 (one unit). There are no exempted or permitted air emission sources in B334.

Building 332 of the Superblock has a wastewater retention system that consists of two 1100-gal carbon steel tanks located in a covered concrete vault on the west side of Building 332. This system is designed and managed to routinely accept nonhazardous waste water from sinks in the RMA chemistry and photography laboratories and from the decontamination shower in Room 1322C. The sinks and the shower are labeled to show that they drain to the retention tanks. The wastewater retention tanks are connected via locked valves to the sanitary sewer system. The wastewater retention tank contents are released to the sanitary sewer after sampling and completion of a Wastewater Discharge Approval Record to ensure that retention tank releases to the sanitary sewer meet the LLNL internal discharge limits. There are no wastewater retention tank systems serving B331 or B334. Liquid experimental wastes generated in B331 are collected in containers and managed appropriately as hazardous, radioactive, or mixed wastes. No experimental wastes are generated in B334.

FMs have the responsibility for identifying the need for air permits and exemptions. Such needs would be recognized during the planning process for new or revised facility and programmatic activities, after the work scope has been defined and the hazards and controls are being considered. An LLNL Environmental Analyst is involved during this process and is able to provide guidance on formal permitting.

\subsection{Management of Hazardous, Radioactive, and Mixed Waste}

Each Superblock FM is responsible for managing low-level (LLW), transuranic (TRU), hazardous, and mixed waste materials in accordance with the Laboratory's Waste Certification Program, the Waste Isolation Pilot Plant (WIPP), the Nevada Waste Disposal Site, and all State and Federal regulations. LLNL publishes a Waste Acceptance Criteria (UCRL-MA-115877) to provide detailed guidance on identifying and 
categorizing various forms of waste that might be generated in its operations and activities. The information below is summarized from that document.

Waste is handled as hazardous if it contains hazardous constituents or characteristics identified in federal or state regulations. Hazardous wastes shall be managed according to the policies and procedures identified in the ES\&HM, Volume III, and presented in the course "Hazardous Waste Generation and Certification" (EP0006). Waste generators and their supervisors are required to attend the initial EP0006 course and the "Hazardous Waste Generation and Certification Refresher" (EP0006R) annually thereafter.

TRU waste is, without regard to source or form, radioactive waste that is contaminated with alpha-emitting transuranium radionuclides with half-lives $>20 \mathrm{yr}$ and concentrations $>100 \mathrm{nCi} / \mathrm{g}$. All TRU waste generators are required to be trained in LLNL's formal EP0021 course, "TRU Waste Generation and Certification," and the preparation, packaging, and labeling of TRU waste must comply with the requirements in the LLNL TRU Waste Certification Program and Quality Assurance Plan (M-078-121).

LLW or non-TRU waste is, without regard to source or form, waste that contains only radioactivity (no hazardous chemicals) and is not classified as high-level or TRU waste. Preparation, packaging, and labeling of LLW must comply with the requirements in the LLNL LLW Certification Program and Quality Assurance Plan (M-078-95).

Mixed waste is defined as waste that contains both federally regulated (RCRA) hazardous and Department of Energy (DOE)-managed radioactive constituents under the Atomic Energy Act. These wastes can be LLW or TRU mixed. Mixed wastes are subject to the same regulations as federally defined hazardous waste in addition to radioactive waste management requirements prescribed by DOE Order 5820.2A. Classified LLW or TRU mixed waste is appropriately declassified prior to disposal as mixed radioactive waste because no facilities exist for it.

Workplace accumulation of hazardous and mixed waste is conducted in accordance with procedures identified in the ES\&HM, Volume III, and presented in EP0006. These procedures describe volume and time restrictions for accumulating these wastes. Waste Accumulation Areas (WAAs) for each Superblock facility have been identified. WAAs are operated in accordance with the requirements and procedures identified in the ES\&HM, Volume III, and presented in the course "Waste Accumulation Area (WAA) Personnel Training" (EP0053). All workers involved in the generation and handling of waste are required to be appropriately trained in all safety aspects of the workplace hazards prior to working. Individual responsibility for safe operations, as well as stop-work empowerment, is stressed in all the courses. LLNL provides training courses through the Hazards Control and Environmental Protection Departments.

\subsection{Interfaces with the Environmental Protection Department}

The LLNL Environmental Protecton Department (EPD) is the lead environmental support organization to provide the Superblock facilities with guidance, expertise, and assistance in complying with applicable environmental requirements. Superblock facilities interface with the EPD through the Environmental Analyst of the ES\&H Team 1 and a resident hazardous and radioactive waste technician matrixed from the Hazardous Waste 
Management (HWM) Division of the EPD. They are on-call to provide their expertise when the ES\&H Team 1 Leader or the chair of the FEDRC requests their presence. On request, either the Environmental Analyst or waste coordinator, or both, sit in on workplanning meetings and provide comments on environmental and waste issues that may be part of a new or expanded activity or operation. 
This page intentionally left blank. 


\subsection{Superblock Safety Management System Mechanisms}

This section shows how the five core functions and the seven guiding principles are developed, evaluated, and implemented at the Superblock level, consistent with the objectives, core functions, and guiding principles presented in the DOE SMS Policy. Details for the facility and activity levels are given in Appendices A, B, and C for Buildings 332,331 , and 334 , respectively.

\subsection{Introduction}

The relationship between the five core functions and the seven guiding principles as described in Chapter 2 of the DOE Safety Management System Guide is shown in Table 1.

Table 1. Matrix showing how and where core functions and guiding principles are related and addressed for the Superblock.

\begin{tabular}{|c|l|c|}
\hline \multicolumn{1}{|c|}{ Core Functions } & \multicolumn{1}{|c|}{ Guiding Principles } & $\begin{array}{c}\text { Section } \\
\text { Number }\end{array}$ \\
\hline- & 1. Line Management Responsibilities & 6.2 \\
\hline- & 2. Clear Roles and Responsibilities & 6.2 \\
\hline- & 3. Competence per Responsibilities & 6.2 \\
\hline 1. Define Scope of Work & 4. Balanced Priorities & 6.3 \\
\hline 2. Analyze Hazards & \multicolumn{1}{|c|}{-} & 6.4 \\
\hline 3. Develop and Implement Controls & $\begin{array}{l}\text { 5. Identification of Safety Standards } \\
\text { 6. Tailor Hazard Controls to Work }\end{array}$ & 6.5 \\
\hline 4. Perform Work & 7. Operations Authorization & 6.6 \\
\hline $\begin{array}{l}\text { 5. Provide Fcedback and Continuous } \\
\text { Improvements }\end{array}$ & - & 6.7 \\
\hline
\end{tabular}

\subsection{Roles and Responsibilities}

The three guiding principles listed below are related to roles and responsibilities, which are applicable to all five core functions. Sections 6.2.1,6.2.2, and 6.2.3 provide details.

- Guiding Principle 1 - Line Management Responsibilities for Safety. ।

- Guiding Principle 2 - Clear Roles and Responsibilities.

- Guiding Principle 3 - Competence Commensurate with Responsibilities.

\subsubsection{Line Management Responsibilities for Safety}

As described in Section 4.6 of the LLNL ISM System Description and the ES\&HM, Volume I, Part 2, the Laboratory Director has assigned to ADs direct responsibility for 
conducting the Laboratory's programmatic work and primary responsibility for implementing the Laboratory's ES\&H policies in the performance of that work. In carrying out these responsibilities, ADs can simultaneously function in one or more of the following roles:

- Program AD - Responsible for carrying out program operations.

- Facility AD - Responsible for operating and maintaining the assigned facilities (buildings or areas).

- Payroll AD - Responsible for assigning employees on his/her payroll accounts to program operations or facility operations and maintenance.

Figure 3 depicts the management structure related to the Superblock operation. The Associate Director for Defense \& Nuclear Technologies (AD/DNT) is the Facility AD for Superblock facilities. The responsibility for safe facility operations flows directly from him to the Nuclear Materials Technology (NMT) Program Leader, through the Deputy for Facility Operations, to the FM for each building. Several Programs (e.g., DNT, Lasers, the Nonproliferation, Arms Control, and International Security Program) conduct program operations in the Superblock via the NMT Program Leader and the Deputy for Programs. Also, Superblock workers are assigned by a number of Payroll ADs (e.g., Engineering, Chemistry, and DNT) to program operations, facility operations and maintenance, or S\&S.

Consistent with the concept described above for various ADs, Figure 4.2 in the LLNL ISM System Description shows the relationships within the Laboratory organizational structure.

\subsubsection{Clear Roles and Responsibilities}

The overall responsibility of the NMT Program I eader is to ensure that ES\&H controls are in place for operations and that those operations in the Superblock facilities are conducted by facility workers (including program users and S\&S) and personnel from supporting organizations such that the public, the environment, and the workers are protected. Specifically, the NMT Program Leader is responsible for:

- Understanding and implementing the applicable security and ES\&H laws, regulations, and Laboratory policy requirements in the Superblock.

- Managing the Superblock in a manner consistent with the Superblock ISMS Description that maintains worker safety, prevents radioactive releases from the Superblock facilities, minimizes any environmental impact, and maintains the safeguards and security aspects inherent to working with classified and SNM. This implies balancing priorities by eliminating worker contamination, minimizing worker exposure to radiation, minimizing waste, ensuring that building safety systems are operational and maintained, and protecting classified and SNM, while ensuring that the mission is accomplished.

- Providing quality support to the programs' activities within the Superblock while keeping the cost of this support within the allocated budget. 


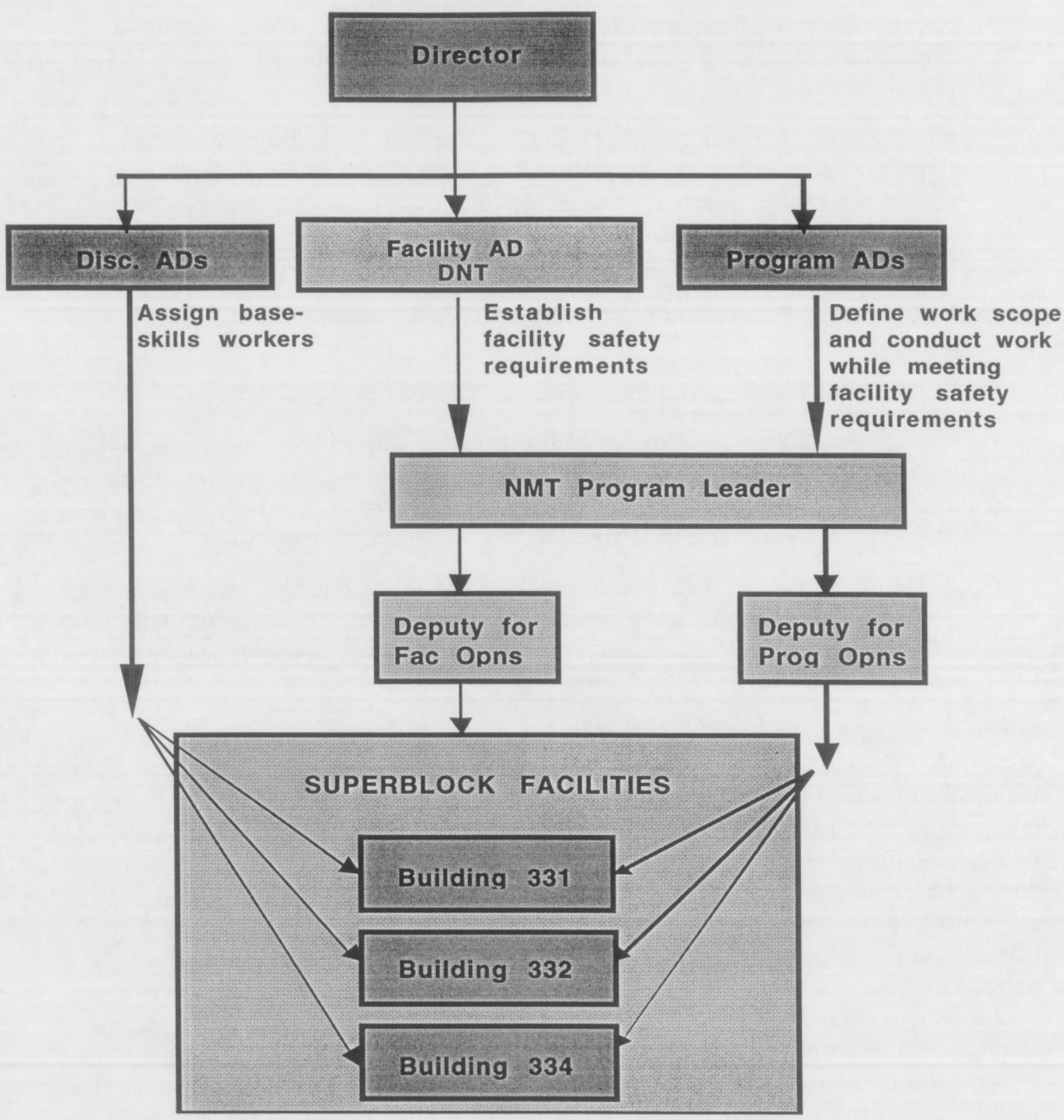

Figure 3. Management structure related to the Superblock operation. 
- Representing the Defense \& Nuclear Technologies Directorate and the Superblock in dealing with the Laboratory, the Department of Energy, and other organizations.

- Guiding and reviewing facility safety documents, including Safety Analysis Reports, Technical Safety Requirements, Facility Safety Plans, and Level A operational safety plans.

- Providing operational management and coordination of the groups that support the Superblock: the Materials Management Section, the Plutonium/Tritium Engineering Section, Plant Engineering, ES\&H Team 1, and Safeguards and Security.

- Providing leadership and mentoring to FMs within the Superblock.

- Providing a diverse workforce environment to Superblock employees while implementing the applicable LLNL and DNT policies and regulations in the areas of security, classification, ES\&H, business, financial, human resources, property management, procurement, and resource management.

- Adhering to standards of sound business management and people management practices, i.e., two-way communications, performance management, employee development, effective conflict resolution, workforce diversity, and attention to required training.

Assigned through the NMT Program Deputy for Facility Operations, the comprehensive set of ES\&H responsibilities flows to the individual Superblock FMs. The general ES\&H responsibilities for FMs and workers are documented in the ES\&HM; Volume I, Part 2. In general, FMs' ES\&H responsibilities ensure compliance with applicable orders and regulations, proper conduct of operations, safety plans, training, maintaining the efficacy of the authorization basis, and communicating all these requirements to facility and support personnel. The FMs establish the controls within which the facility residents, support personnel, and users must operate. In addition, they establish systems to ensure continuous feedback and improvement based on lessons learned. The lessons learned may be through local performance in operations and processes or experience at other LLNL and DOE facilities. More specific facility-related responsibilities are detailed in the Appendices A, B and C of this document. Consistent with their stop-work empowerment, the facility workers' responsibility is to perform their work within the controls.

Responsibilities for complying with ES\&H plans, procedures, and controls are assigned through the NMT Program Leader and Deputy for Programmatic Operations and the Associate Program Leaders for Tritium Programs, Defense Technologies, Plutonium Processing Technology, and Plutonium Ceramification to the workers performing those programmatic activities occurring under FSPs and OSPs in each facility.

\subsubsection{Competence Commensurate with Responsibilities}

As stated in the LLNL Training Program Manual, "Employees at the Laboratory are expected to be capable of carrying out their work effectively and safely. In many cases, they must have specific skills, knowledge, and abilities in order to be given an assignment in a particular job in a particular facility. To assure that such skills, 
knowledge, and abilities are in place, specific training may be required." Job skills and job-related training fall into three categories: base skills, assignment-specific training, and facility-specific training. The Livermore Training and Requirements Information Network (LTRAIN) contains all completed training course records, the course catalog, and the requirements tracking system. Responsibilities for training are given in the LLNL Training Program Manual and summarized as follows:

- Program ADs identify training requirements beyond the base skills for employees working in activities under their responsibilities, including projectspecific requirements; document the basis for the requirements they have established; and communicate those requirements to the payroll managers, supervisors, employees, and the affected FMs.

- Payroll ADs ensure that their employees have the base skills needed for their work categories and maintain their employees' job components information.

- Facility ADs establish facility-specific training requirements for those working in their facilities and document the basis for the requirements they have established. Each FM requires that personnel conform to the facility's TIM through constant assessment by the NMTP Training Manager to determine that the required training is current. The required training depends on the individual's work, but specifically includes facility-specific safety topics. FMs have the authority to deny access to any personnel found to be out of compliance with the required training.

Personnel, before being selected to work regularly in the Superblock, are required to go through the LLNL employment process for both internal transfers or external recruiting. The process starts with a written job posting that contains the nature and scope of the job, essential duties, essential and desired skills, knowledge, and abilities, and academic credentials. Once a person is selected for working in the Superblock facilities, he or she is required to complete facility-related training requirements as described in the Appendices (see Section 6.2, Roles and Responsibilities, for each facility). Annual performance reviews for all Superblock personnel are conducted through appropriate payroll organizations with inputs from immediate day-to-day supervisors. The review results, including identification of areas for improvement, are documented in the annual performance appraisals to ensure that the point of "competence commensurate with responsibilities" is addressed for each of the Superblock personnel.

\subsubsection{Related Documents}

This section lists supporting documents related to the areas of roles and responsibilities for the Superblock.

Roles and Responsibilities (Guiding Principles 1, 2, and 3)

- Superblock ISMS Description document

- LLNL Environmental, Safety \& Health Manual (ESEHM):

-Volume I, Part 2, "Management Requirements"

-Volume I, Part 4, "Written Plans and Procedures"

-Volume I, Part 5, "Feedback and Improvement"

-Volume II, Part 3, "Construction, Maintenance, Mechanical Equipment, Working Surfaces"

-Volume II, Part 12, "General Controls-Procedures"

-Volume V, Part 1, "Personnel" (continued next page) 


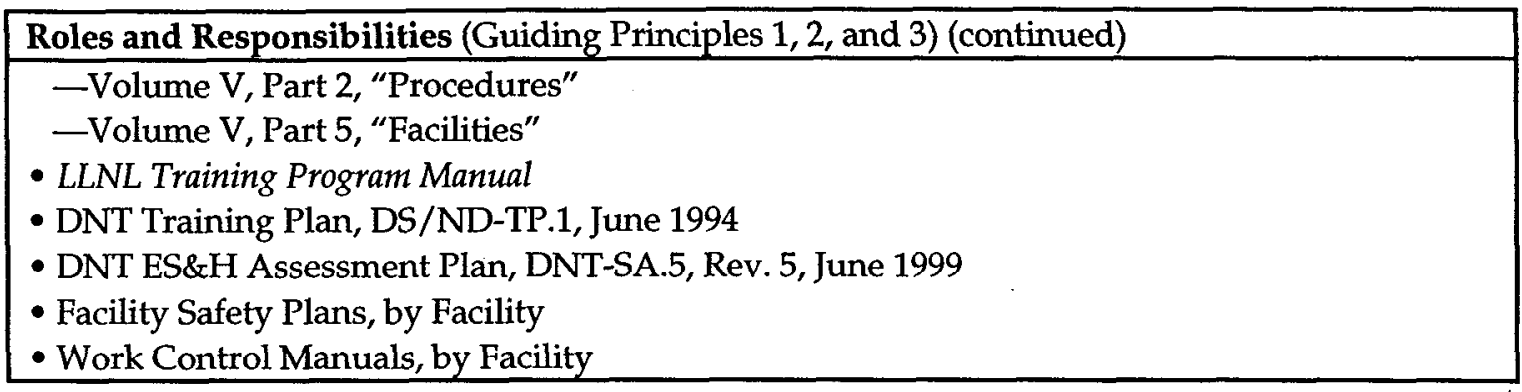

\subsection{Work Planning and Prioritization (Core Function 1 - Define the Scope of Work; Guiding Principle 4 - Balanced Priorities)}

\subsubsection{Define the Scope of Work}

At the Superblock level, the Laboratory mission concerning national security-ensuring the safety, security, and reliability of the U.S. nuclear stockpile and preventing the proliferation of weapons of mass destruction-is translated into work activities. Performance objectives and expectations, including safety, are established through Authorization Agreements (between the AD/DNT and the DOE/OAK Manager) for each Superblock facility. Budget allocations must match the performance objectives, including ES\&H and maintenance requirements, prior to acceptance of the agreements. Consistent with the ES\&HM, Volumes I, II, and V (see table in Section 6.2.4), safety documentation for each Superblock facility is prepared to establish clear lines of authority in defining the scope of the work for programmatic work and facility-related operations, including approval of subsequent changes.

In addition, each Superblock facility is required to establish its work planning and controls process so that the defined work can proceed accordingly. The defined work includes both programmatic work and facility-related maintenance activities. The definition is provided to satisfy the requirements of each facility's Work Control/Design Change Control Process Manual (Work Control Manual or WCM), which leads to the hazards identification, analysis, mitigation, control, etc. The Work Permit process described in the WCM usually results in a Work Permit document which, when properly filled out and authorized, is the facility's primary controlling document for ensuring the safe, coordinated conduct of the work. See Section 6.3.1 in each Appendix herein for facility-specific information on the WCMs.

An Authorization Agreement between the AD/DNT and DOE/OAK establishes and defines authorized operations within the facilities. Specific operations encompassed by the Safety Analysis Reports are further described by the FSP and, where applicable, OSPs. The FSP and OSPs define the controls applicable for operations based ùpon the hazards analyses.

FMs recognize two separate and distinct systems for management of work. One system addresses the facility and the confinement controls maintaincd in accordance with its Technical Safety Requirements (TSR). The second concerns the (programmatic) mission work controlled by the FSP and OSPs. The two systems are complementary and together comprise all the requirements to maintain the safety controls to mitigate hazards within the bounds of the SAR. The USQ processes are designed to maintain the 
integrity of the systems and processes within the safety envelope. For programmatic activities, the FM has the responsibility for establishing the controls, and the programmatic Responsible Individual has the responsibility for ensuring, on a day-today basis, that the personnel performing the work are doing so within the controls. The FM has responsibility for both establishment and compliance for facility operations activities. See ES\&HM, Volume V, Part 2, "Procedures," for LLNL requirements on USQs. See also the Appendices herein, particularly Sections 6.3.1, for additional information on facility-specific USQ processes.

\subsubsection{Balanced Priorities}

In dealing with priorities, each Superblock facility has a process to reconcile any internal and external conflicts (e.g., over schedule, resources allocation, etc.), as described in the Appendices. Resources are effectively allocated to address safety, programmatic, and operational considerations. The goal is to define work and allocate resources so that work is done safely and contributes to accomplishment of the Laboratory mission.

Before each fiscal year, the Superblock FMs, along with the ES\&H Team 1 Leader and responsible managers from Safeguards and Security, Materials Management, and Criticality Safety, present to the NMT Program Leader their work plans listing priorities, including ES\&H-related activities and maintenance work for safety-related systems and equipment. The prioritized lists include the resource requirements for associated ES\&H and maintenance activities. This ensures that budgeting for these requirements is always considered in balancing priorities between mission-related activities and ES\&H. Section 8.0 of this document contains further information on program and budget execution. The process is repeated approximately quarterly, allowing the resetting of priorities as work continues and funding and spending levels change.

\subsubsection{Related Documents}

This section lists supporting documents related to the areas of work planning and prioritization for the Superblock.

\begin{tabular}{|l|}
\hline Work Planning \& Prioritization (Core Function 1 and Guiding Principle 4) \\
\hline - Superblock ISMS Description document \\
- LLNL Environmental, Safety \& Health Manual (ESEHM): \\
-Volume I, Part 2, "Management Requirements" \\
-Volume I, Part 4, "Written Plans and Procedures" \\
-Volume II, Part 3, "Construction, Maintenance, Mechanical Equipment, Working Surfaces" \\
-Volume II, Part 12, "General Controls-Procedures" \\
-Volume V, Part 2, "Procedures" \\
- Work Control Manuals, by Facility
\end{tabular}




\subsection{Hazards Analysis (Core Function 2 - Analyze Hazards)}

\subsubsection{Identify and Analyze Hazards}

Hazard identification and analyses (i.e., 1992 Site-wide EIS/EIR and 1999 EIR Addendum) are performed at the Superblock facility level from the work defined in the site-wide mission (contained in Appendix E of DOE/UC Contract 48) to the processes at the individual facility (i.e., Safety Analysis Report [SAR]) to the individual operational or maintenance item, which is contemplated within each facility (e.g., FSP, OSPs, Work Permits).

All types of hazards such as nuclear, chemical, industrial, fire, natural phenomena, and construction are identified in the individual facility SARs, which are prepared by the facility staff with support from facility workers (including program users) and supporting organizations. Also the SARs address and quantify the potential seriousness and likelihood of hazards for all the stages of work to be performed, ranging from normal operations, surveillance, maintenance, facility and equipment modification, to decontamination and decommissioning. These quantified hazards, combined with the USQ process, establish the safety boundaries outside of which no new operation or activity can be allowed to exist without explicit approval from DOE/OAK. The USQ process also includes situations such as as-found discrepant conditions, operational events, and receipts of new information under DOE Order 5480.21, as implemented by LLNL. The SAR preparation in the Superblock follows the ES\&HM, Volume V, Part 2. This Part refers detailed guidance to DOE Standard 3009, Preparation Guide for U.S. Department of Energy Nonreactor Nuclear Facility Safety Reports, in concert with DOE Order 5480.23, "Nuclear Safety Analysis Reports." Submittal of annual updates of the SARs to DOE/OAK for approval is required.

Each Superblock facility with a DOE-approved SAR is required to maintain the accuracy of the SAR through the USQ process described in the ES\&HM, Volume V, Part 2, or through a facility-specific USQ procedure.

Also at the facility level and the activity level, FSPs and OSPs contain identified hazards consistent with the respective SARs. More detail on the preparation and use of these, including worker involvement from the beginning of the process, is in Appendices A, B, and $C$ of this document. S\&S activities are subjected to the same OSP standards as programmatic and facility operational activities.

Facilities within the Superblock use WCMs to establish guidelines and provide procedures for analyzing hazards as a part of both the programmatic and facility maintenance work processes. See Appendices A, B, and C of this document for more detail on the hazards identification and analysis, and other procedures to control potentially hazardous situations, required by the WCMs.

\subsubsection{Categorize Hazards}

Categorizing hazards of nuclear facilities initially is conducted by following DOE Standard 1027, Hazard Categorization and Accident Analysis Techniques for Compliance with DOE Order 5480.23, Nuclear Safety Analysis Reports, and documented in the SAR. Hazards 
for specific operations and activities are categorized in accordance with the requirements of the ES\&HM. WCMs for each facility identify categories of increasingly complex and/or potentially hazardous work activities with commensurate hazard analysis and associated controls. See Appendices A, B, and C.

\subsubsection{Related Documents}

This section lists supporting documents related to the areas of hazard analysis for the Superblock.

Hazard Analysis (Core Function 2)

- Superblock ISMS Description document

- LLNL Environmental, Safety \& Health Manual (ES\&HM):

-Volume I, Part 2, "Management Requirements"

-Volume I, Part 4, "Written Plans and Procedures"

-Volume II, Part 3, "Construction, Maintenance, Mechanical Equipment, Working Surfaces"

-Volume II, Part 12, "General Controls -- Procedures"

-Volume V, Part 2, "Procedures"

-Volume V, Part 5, "Facilities"

- Facility Safety Plans, by Facility

- Work Control Manuals, by Facility

\subsection{Hazard Mitigation and Control (Core Function 3 - Develop and Implement Hazard Controls; Guiding Principle 5 - Identification of Safety Standards and Requirements; Guiding Principle 6 - Hazard Controls Tailored to Work Being Performed)}

\subsubsection{Develop and Implement Hazard Controls}

The results of hazard and accident analyses documented (working with facility workers, program users, and personnel from supporting organizations) in the facility SARs provide each of the Superblock facilities with vital information for developing controls to mitigate hazards. For the Superblock facilities, there are three types of controls: (1) engineered controls, (2) administrative controls, and (3) personal protection equipment (PPE).

Engineered controls (e.g., containment, shielding, interlocks, fences, barricades, and guards) developed for structures, mechanical systems, and electrical equipment are the first choice in defining controls to protect workers and the public. Administrative controls are used to maintain the integrity of the engineered systems (i.e., configuration management, including change control process) and provide the administrative structure (e.g., work control process) for operations, maintenance, ES\&H programs, and S\&S activities. To ensure that the engineered controls are reliable, administrative controls are needed to maintain system configuration and operability. Reliability of the engineered systems is dependent on adequate operating and maintenance procedures, configuration management, and safety documentation. The implementation of the TSRs ensures that engineered barriers and operating parameters are maintained within the facility's safety authorization basis. Personal protection equipment is utilized when 
engineered barriers and administrative controls are either unavailable or insufficient to mitigate the hazards.

Specific controls for the Superblock facilities are contained in the Appendices.

\subsubsection{Identification of Safety Standards and Requirements}

The results of hazard and accident analyses documented in the facility SARs and other job hazard analyses are used to identify an applicable set of safety standards and requirements (i.e., Rules, DOE Orders and the associated Technical Standards, guides, manuals, national consensus standards, and the Work Smart Standards [WSS] set that is being implemented by LLNL). The identified standards define the basis for the controls that must be put in place to keep the facility within the safety envelope. Whereas many of the safety standards and requirements in the SAR may tend to protect primarily the public and environment, the WSS also function to maintain safe working conditions for the workers in the facilities. See Section 9.0 for additional discussion on WSS. See also Section 6.5.1 of each Appendix for particulars at the facility level, as a graded approach is used for the three buildings that depends on the hazards present.

For proposed new work, the scope is studied and analyzed by subject-matter experts who apply the appropriate standards, as identified above. If analysis of the proposed new work identifies new hazards not covered under the approved standards and requirements, the USQ process is used. When the Superblock adopts the LLNL WSS, then, in addition to using the USQ process, all work and hazards list modifications will be submitted through the established site-wide WSS process.

\subsubsection{Hazard Controls Tailored to Work Being Performed}

Each Superblock facility established a management process for identifying administrative controls, safety controls, safety programs, and other conditions on the work (e.g., TSRs). The identified controls that constitute the safety envelope are tailored to the work and the associate hazards. In other words, the controls address all activities such as programmatic operations, surveillance, maintenance, facility and equipment modification, and S\&S activities. Also, the controls cover all aspects of work from initiation, to review and authorization, to execution.

To implement necessary controls, each Superblock facility, along with facility workers (including program users) and personnel from supporting organizations, has developed a set of procedures and documentation (i.e., the work control process) to be used by workers at all levels. The hierarchy of safety controls is based on the hazards identified in the SAR used for establishing the safety envelope for the facilities. These accident scenarios are mitigated at the highest level through TSRs, and are enforced through monitoring, surveillance, and operational controls defined in various facility-specific procedures and plans. FSPs, OSPs, and Work Permits implement the controls for programmatic operations. FSPs describe the safety and environmental controls as facility-standard practices and for long-term activities. FSPs are required to be reviewed, updated, and reissued every three years. Changes to FSPs are approved and issued as required during the three-year period. OSPs describe controls for individual, 
limited-term activities and are reviewed and approved annually. Work Permits also describe controls for individual, limited-term activities and are generally valid for seven days, but can be extended. Controls include specific safety requirements (e.g., lockout and tag requirements described in the ES\&HM, Volume II, Part13).

\subsubsection{Related Documents}

This section lists supporting documents related to the areas of hazard mitigation and controls for the Superblock.

Hazard Mitigation \& Control (Core Function 3, and Guiding Principles 5 and 6)

- Superblock ISMS Description document

- LLNL Environmental, Safety \& Health Manual (ES\&HM):

-Volume I, Part 2, "Management Requirements"

-Volume I, Part 4, "Written Plans and Procedures"

-Volume II, Part 1, "Biological"

-Volume II, Part 2, "Chemical"

-Volume II, Part 3, "Construction, Maintenance, Mechanical Equipment, Working Surfaces"

-Volume II, Part 4, "Electrical"

-Volume II, Part 5, "Explosives, Firearms"

-Volume II, Part 6, "Pressure, Noise, Hazardous Atmospheres"

-Volume II, Part 7, "Worker Capability, Physical or Repetitive Motion"

-Volume II, Part 8, “Ionizing, Non-Ionizing Radiation"

-Volume II, Part 9, "Transportation"

-Volume II, Part 10, "Emergencies, Earthquakes, Fire"

-Volume II, Part 12, "General Controls -- Procedures"

-Volume II, Part 13, "General Controls - Safety Equipment"

-Volume III, "Environment - Hazards and Controls," (replaced LLNL Environmental Compliance Manual)

-Volume IV, Part 1, “Occupational Health"

-Volume IV, Part 5, "Suspect and Counterfeit Materials"

-Volume V, Part 1, "Nuclear Facility Personnel"

- LLNL Maintenance Implementation Plan for Nonreactor Nuclear Facilities

- LLNL Training Program Manual

- LLNL Quality Assurance Program

- LLNL Onsite Hazardous Materials Packaging and Transportation Safety Manual

- LLNL Mechanical Engineering Design Safety Standards

- LLNL Electrical Engineering Standards Manual

- DNT Operational Safety Plan Protocol, January 1997

- DNT Calibration Program for Measuring and Test Equipment, July 1997

- DNT Waste Minimization and Pollution Prevention Plan, DNT-WMPP.2, October 1997

- DNT Quality Assurance Plan, DNT-QA.0, February 1995 


\subsection{Work Authorization and Execution (Core Function 4 - Perform Work; Guiding Principle 7 - Operations Authorization)}

\subsubsection{Confirm Readiness}

Consistent with DOE Order 5480.31, "Startup and Restart of Nuclear Facilities," the ES\&HM, Volume V, Part 5, provides readiness guidance for nuclear facilities. Each Superblock facility establishes a process, as described in the Appendices, to confirm adequate preparation prior to authorizing the performance of work at the facility, project, or activity level. The DOE may also require additional reviews of operations and safety in accordance with the AA and the ES\&HM. As a minimum, the process is required to ensure that:

- Personnel are qualified and trained to work in accordance with the controls established.

- Controls are adequate to ensure safe work performance and to prevent accidents, uncontrolled releases, or unacceptable exposures to hazardous materials.

- Necessary safety functions and required interfaces have been established.

- Operability of the necessary facility or process system required for safe operation has been (or will be) verified in accordance with appropriate Authorization Agreements.

The formality and rigor of the review process and the extent of documentation and level of authority for agreement are based on the hazards and the complexity of the work being performed within an acceptable level of risk.

\subsubsection{Operations Authorization}

Each Superblock facility's operation authorization is documented in an appropriate Authorization Agreement signed and agreed upon by the AD/DNT and DOE/OAK Manager. The Authorization Agreement ${ }^{1}$ incorporates the results of DOE's review of the facility's proposed authorization basis for a defined scope of work. The Authorization Agreement contains key terms and conditions (controls and commitments) under which the facility is authorized to perform the work. Any changes to these terms and conditions requires DOE approval. For day-to-day operations, each Superblock facility establishes its work control process that includes work authorization.

\subsubsection{Perform Work Safely}

Each Superblock facility establishes a process to ensure that safety requirements are integrated from work planning into work performance. Procedures and safety programs are adequate to ensure that the work is performed within the controls developed. The controls include facility commitments such as conduct of operations

0

${ }^{1}$ The authorization agreement concept for DOE nuclear facilities was introduced by the Defense Nuclear Safety Board (DNFSB) in its technical report, DNFSB/TECH-5, Fundamental for Understanding Standard-based Safety Management of Department of Energy Defense Nuclear Facilities, dated May 1995. 
and maintenance programs, personnel training and qualification program, worker safety programs, or specific building safety systems.

The ES\&HM, Volume I, Part 2, provides guidance on how to implement DOE Order 5480.19, "Conduct of Operations Requirements for DOE Facilities." The graded approach is used based on the hazard classification of each facility and the impact an operation could have on health, safety, or the environment or on the programmatic mission. Each Superblock facility follows the Part and documents its compliance status.

For maintenance activities, the LLNL Maintenance Implementation Plan for Nonreactor Nuclear Facilities provides directions to ensure availability and operability of Superblock structures, systems, and components important to safe and reliable facility operation.

As can be seen in the Appendices A, B, and C of this document, before starting work in any of the Superblock facilities, responsible personnel confirm that workers are competent and properly trained people with a clear set of expectations from management. As stated in Section 6.2, workers understand under LLNL and Facility procedures that they have the right and responsibility to stop potentially unsafe work and report unsafe situations.

\subsubsection{Performance Measures}

Appendix F of DOE/UC Contract 48 contains the performance objectives, criteria, and measures (POCMs) that are the components of the performance-based management system utilized by UC and DOE for Laboratory oversight as described in Clause 2.6, Performance-Based Management. Success in achieving the objectives defined by the Appendix F performance measures depends upon meeting the expectations established at the activity, facility, and the institutional levels.

The Superblock, as part of the Laboratory, will contribute to the institutional POCMs. Two of the specific areas of the Appendix F performance measures that have been identified for the Superblock level are:

- Environment, Safety \& Health (Section B, Part II-2).

- Facility Management (Section B, Part II-3).

The Superblock measures the effectiveness of its performance through a variety of established mechanisms, including:

- Contract performance measures.

- Annual budget reviews.

- Completion of programmatic deliverables.

- Operating status for the Superblock facilities in relationship to the authorization basis.

- Appraisals, audits, self-assessments, and other feedback and improvement measures. 
- Closure of safety-related corrective actions, including DefTrack items.

- Number of Occurrence Reports and the nature of the occurrences.

- Accidents and injuries statistics.

Details of performance measures for each facility and its associated activity level are covered in the Appendices.

\subsubsection{Related Documents}

This section lists supporting documents related to the areas of work authorization and extension for the Superblock.

Hazard Analysis (Core Function 2)

- Superblock ISMS Description document

- LLNL Environmental, Safety \& Health Manual (ES\&HM):

-Volume I, Part 2, "Management Requirements"

-Volume V, Part 5, "Facilities"

- Facility Safety Plans, by Facility

- Work Control Manuals, by Facility

\subsection{Performance Monitoring and Improvement (Core Function 5 - Provide Feedback and Continuous Improvements)}

\subsubsection{Collect Feedback Information}

The ES\&HM, Volume I, Part 4, provides requirements and guidance for preparing directorate Self-Assessment Plans. The DNT ES\&H Self-Assessment Plan is developed accordingly. The objective of the Plan is to develop and promote a proactive approach to ES\&H and QM as an integrated component of total directorate management. The self-assessment process consists of four elements: planning, conducting, analyzing, and documenting. The Plan, including the scope of self-assessment and the associated schedules, is assembled by the DNT Assurance Manager and is revised every two years with input from the DNT Program Leaders, including the NMT Program Leader. The NMT Program Leader receives input from the FMs through the Deputy for Facility Operations and, for programmatic activities, from the program Group Leaders through the Deputy for Program Operations.

Supplementing the DNT ES\&H Self-Assessment Plan, the NMTP Feedback and Improvement Program (FIP) provides more detailed information on areas of assessment and opportunities for all facility personnel to contribute to a safer Superblock. The FIP is designed to satisfy the requirements of 10 CFR 830.120, "Nuclear Safety Management," Quality Assurance Requirements, and the Authorization Bases.

Under the DNT Self-Assessment Plan's terms, each Superblock facility collects feedback information on ES\&H deficiencies from internal Laboratory audits (e.g., Assurance Review Office), the LLNL Lessons Learned Program, occurrence reporting, incident analysis reports, external audits (DOE and other agencies), DNFSB trip reports, DOE Operating Experience Weekly Summary, and any other sources, through the DNI 
Assurance Manager. The NMTP FIP includes those elements and self-assessments, inspections, walk-throughs, lessons learned, analysis of deficiencies and corrective actions, and performance measures. The self-assessment results provide feedback information to the respective line management; the inspections and walk-throughs identify issues for correction and improvement; the analyses provide forewarning of possible problem areas; the Lessons Learned program provides opportunities for improvement; the Corrective Action Request (CAR) program provides an opportunity for anyone who notes a shortcoming to bring it to management's attention (see also Section 6.7.1 in Appendices A, B, and C); and the Objective Performance Measures Reports, collected from appropriate site and facility sources, give managers information on the progress of key indicators toward specific targets to improve the quality of work in the facilities.

The FIP is designed to assist management in confirming that programmatic activities and facility operations are operating within the facilities' Authorization Bases broadly and deeply. Management looks over a broad area for systemic, process, and management issues, referred to as "breadth"investigations. Thus, they locate and fix known problem areas, locate areas of concern before they become problems, and use the lessons learned to improve future activities and operations. They also look for smaller issues, deeply, over many sample areas, referred to as "depth"investigations. The following matrix illustrates the comprehensive means by which the LLNL, DNT, and NMTP FIP cover the breadth and depth of processes as described above:

\begin{tabular}{|c|c|c|c|}
\hline $\begin{array}{c}\text { Assessment/Inspection/ } \\
\text { Analysis }\end{array}$ & $\begin{array}{l}\text { Compliance } \\
\text { Issues }\end{array}$ & $\begin{array}{l}\text { Performance } \\
\text { Issues }\end{array}$ & $\begin{array}{l}\text { Breadth/Depth } \\
\text { Coverage }\end{array}$ \\
\hline ARO Assessments & $x$ & & Breadth \\
\hline DNT Assessments & $x$ & & Breadth \\
\hline Formal Self-Assessments & $x$ & & Depth \\
\hline $\begin{array}{l}\text { ES\&H Team } 1 \\
\text { Inspections }\end{array}$ & $x$ & & Depth \\
\hline $\begin{array}{l}\text { Facility Safety Committee } \\
\text { Inspections }\end{array}$ & $x$ & $x$ & Depth \\
\hline $\begin{array}{l}\text { Facility Safety Office } \\
\text { Walk-Throughs }\end{array}$ & $x$ & $x$ & Breadth \& Depth \\
\hline $\begin{array}{l}\text { Facility Walk-Around } \\
\text { Program }\end{array}$ & & $\mathrm{X}$ & Breadth \\
\hline $\begin{array}{l}\text { Lessons Learned } \\
\text { Program }\end{array}$ & $x$ & $x$ & Breadth \& Depth \\
\hline $\begin{array}{l}\text { Monthly Facility Action } \\
\text { Status Report/Analysis } \\
\text { of Master Action } \\
\text { Database (MAD) Items }\end{array}$ & $x$ & $X$ & Breadth \& Depth \\
\hline $\begin{array}{l}\text { Corrective Action } \\
\text { Requests (CAR) }\end{array}$ & $x$ & & Depth \\
\hline $\begin{array}{l}\text { Objective Performance } \\
\text { Measures Report }\end{array}$ & $x$ & & Breadth \\
\hline
\end{tabular}




\subsubsection{Identify Improvement Opportunities}

The LLNL Deficiency Tracking (DefTrack) system has been developed as a tool for management to track the status and closures of ES\&H deficiencies identified through surveys, audits, and inspections. Formal surveys, audits, and inspections that are defined in the DNT Self-Assessment Plan are required to be entered in the DefTrack system, and priorities (i.e., 1A, 1B, 2, 3, and 4, depending on seriousness of the findings) will be assigned to each deficiency. DNT has established as policy that ES\&H-related deficiencies identified as judgments-of-need from incident analyses, corrective actions in occurrence reports, and potential PAAA findings are entered into DefTrack. To determine the most appropriate corrective action and implementation plans, all incident analyses, and any reportable occurrences wherein the root cause is not readily apparent, are subjected to a formal root cause analysis by a group of individuals trained in the process. Likewise, complicated results of trend analyses or other findings will be subjected to the process when deemed appropriate by NMTP management or DOE/Oak representatives. At the very least, corrective actions will be subject to approval by a trained individual, even if not determined by the group process. Corrective actions and implementation plans resulting from the root cause analyses are tracked to closure in the Master Action Database (MAD) or DefTrack.

For deficiencies and issues determined not to warrant entry into the DefTrack system, NMTP has established its own system to document the findings and track for closure. Therefore, improvement opportunities exist either through the formal Laboratory tracking system or the NMTP's management system. As described in the FIP, the Assurance Manager tracks all deficiencies and commitments, adding to it all DefTrack items, in the MAD. Included for each item is information on compliance and ISMS relevance. This information is the basis for identifying areas of possible concern to management. For example, too many items in a specific area, or an unexplained growth, may signal that that area deserves some attention. Likewise, too few items may indicate an area of interest for assessment. Improving the productivity of the facility is the aim of the Objective Performance Measures Report. If targets are not met, an analysis will explain the reasons so that corrective actions can be initiated.

The LLNL Lessons Learned Program (described in Section 6.7.1.6 of the LLNL ISM System Description) is another mechanism providing improvement opportunities for the Superblock activities. As part of this program, the Hazards Control Department regularly reviews internal and external incidents and provides feedback to LLNL Assurance Managers and program leaders verbally or through a published newsletter called "Lessons Learned." Also, the Operating Experience Weekly Summary, published by the DOE's Office of Nuclear and Facility Safety, provides improvement opportunities because the publication contains real data for operating experiences in the DOE complex.

Again, workers are expected and encouraged to identify areas for improvement for safe and improved operations as part of each individual's ES\&H responsibilities defined in the ES\&HM, Volume I, Part 2. In addition to the CAR system, workers provide input for improvement at pre-job meetings, annual OSP revision meetings, and scheduling meetings. 


\subsubsection{Make Changes to Improve}

As mentioned in Section 6.7.2, deficiencies are tracked and documented for closure when corrective actions are completed. Information on types of possible problem areas is gleaned from the database, and the Assurance Manager works with the FMs to identify additional areas for improvement. Objective Performance Measures give progress data on targets established by management, and they provide advanced warning signals if operations or activities require attention. At the FM's discretion, an opportunity to improve is treated as a corrective action and added to the MAD. These processes ensure that improvements will be made from assessments, lessons learned, and other sources, and followed through to completion of the fixes.

\subsubsection{Oversight and Enforcement}

The NMT Program Leader, along with involved program and payroll management, takes appropriate oversight and enforcement responsibilities for work performed in the Superblock as well as for personnel working in the Superblock. The responsibilities of Laboratory management in performing oversight roles are clearly described in the ES\&HM, Volumes I and II. The Assurance Review Office and the DNT Assurance Office perform oversight of Superblock facilities for the Laboratory Director's Office and the AD/DNT, respectively. Interactions with external oversight organizations such as DOE (e.g., Facility Representatives, DP, EH) and the DNFSB are part of facility activities in the Superblock. The NMT Program Leader is the Superblock's PAAA-responsible official. $\mathrm{He}$ acts as the primary contact for dealings with LLNL's PAAA Project Office and ensures open lines of communication among the PAAA Project Office and the Superblock facilities management and programmatic users.

\subsubsection{Related Documents}

This section lists supporting documents related to the areas of performance monitoring and improvement for the Superblock.

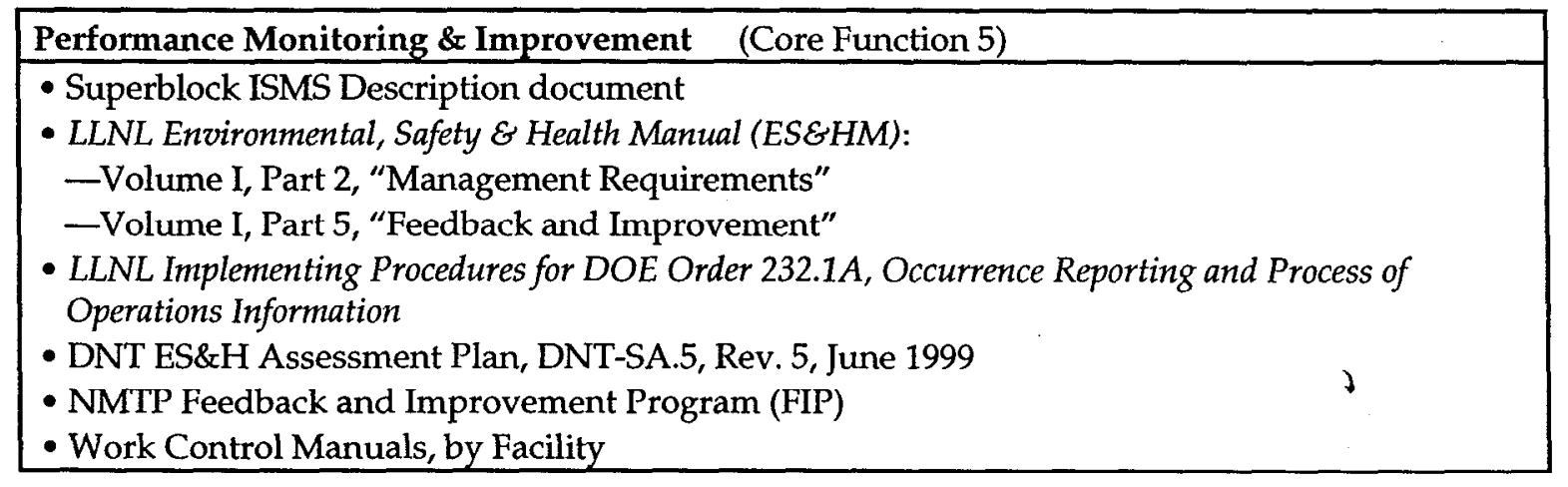


This page intentionally left blank. 


\subsection{Integration}

The following section addresses two specific aspects of the integration of the Superblock ISMS. These are (1) integration of the core functions and guiding principles (Section 7.1) and (2) integration of the core functions throughout all levels (i.e., Superblock, facility, and individual activity) of the organization (Section 7.2).

\subsection{Integration of Core Functions and Guiding Principles}

References to the Superblock-level documents that prescribe each of the mechanisms have been included in Section 6.0. A crosswalk of the documents that reflect the correlation of the core functions and the guiding principles is presented below in Tables 2 through 6 .

The following abbreviations are used in Tables 2 through 6:

AA - Authorization Agreement

EIS/EIR - Environmental Impact Statement/Environmental Impact Report

ES\&HM - LLNL ES\&H Manual

FIP - NMTP Feedback and Improvement Program

MIP - LLNL Maintenance Implementation Plan for Nonreactor Nuclear Facilities

N/A - Not Applicable

QAP - LLNL Quality Assurance Program

SAP - DNT Self-Assessment Plan

SAR - Safety Analysis Report

TSR - Technical Safety Requirements

TPM - LLNL Training Program Manual

Table 2. Define Scope of Work Crosswalk.

\begin{tabular}{|c|c|c|c|c|c|c|}
\hline $\begin{array}{c}\text { Line } \\
\text { Management } \\
\text { Responsibilities } \\
\text { for Safety }\end{array}$ & $\begin{array}{c}\text { Clear Roles } \\
\text { and } \\
\text { Responsibilities }\end{array}$ & $\begin{array}{c}\text { Competence } \\
\text { Commensurate } \\
\text { with } \\
\text { Responsibilities }\end{array}$ & $\begin{array}{l}\text { Balanced } \\
\text { Priorities }\end{array}$ & $\begin{array}{l}\text { Identification } \\
\text { of Safety } \\
\text { Standards } \\
\text { and } \\
\text { Requirements }\end{array}$ & $\begin{array}{c}\text { Hazard } \\
\text { Controls } \\
\text { Tailored to } \\
\text { Work } \\
\text { Being } \\
\text { Performed }\end{array}$ & $\begin{array}{l}\text { Operations } \\
\text { Authorization }\end{array}$ \\
\hline $\begin{array}{l}\text { - ES\&HM } \\
\text { Vol. I, Part } 2\end{array}$ & $\begin{array}{l}\text { - ES\&HM } \\
\text { Vol. I, Part } 2\end{array}$ & $\begin{array}{l}\text { - ES\&HM } \\
\text { Vol. I, Part 2; } \\
\text { Vol. IV, } \\
\text { Part 2; and } \\
\text { Vol. V, Part 1 } \\
\text { - TPM }\end{array}$ & $\begin{array}{l}\text { - ES\&HM } \\
\text { Vol. I, } \\
\text { Part } 2\end{array}$ & $\mathrm{~N} / \mathrm{A}$ & $\begin{array}{l}\mathrm{N} / \mathrm{A} \\
\end{array}$ & $\mathrm{N} / \mathrm{A}$ \\
\hline
\end{tabular}


Table 3. Analyze Hazard Crosswalk.

\begin{tabular}{|l|l|l|l|l|l|l|}
\hline $\begin{array}{c}\text { Line } \\
\text { Responsement } \\
\text { for Safety }\end{array}$ & \multicolumn{1}{c|}{$\begin{array}{c}\text { Clear Roles } \\
\text { and } \\
\text { Responsibilities }\end{array}$} & $\begin{array}{c}\text { Competence } \\
\text { Commensurate } \\
\text { with } \\
\text { Responsibilities }\end{array}$ & $\begin{array}{l}\text { Balanced } \\
\text { Priorities }\end{array}$ & $\begin{array}{c}\text { Identification } \\
\text { of Safety } \\
\text { Standards } \\
\text { and } \\
\text { Requirements }\end{array}$ & $\begin{array}{c}\text { Hazard } \\
\text { Controls } \\
\text { Tailored to } \\
\text { Work } \\
\text { Being } \\
\text { Performed }\end{array}$ & $\begin{array}{c}\text { Operations } \\
\text { Authorization }\end{array}$ \\
\hline $\begin{array}{l}\text { - AA } \\
\text { ES\&HM } \\
\text { Vol. I, Part 2 }\end{array}$ & $\begin{array}{l}\text { - ES\&HM } \\
\text { Vol. I, Part 2 }\end{array}$ & $\begin{array}{l}\text { - AA } \\
\text { ES\&HM } \\
\text { Vol. I, Part 2, } \\
\text { and Vol. IV, } \\
\text { Part 2 } \\
\text { TPM }\end{array}$ & N/A & N/A & N/A & N/A \\
\hline
\end{tabular}

Table 4. Develop/Implement Controls Crosswalk.

\begin{tabular}{|c|c|c|c|c|c|c|}
\hline $\begin{array}{c}\text { Line } \\
\text { Management } \\
\text { Responsibilities } \\
\text { for Safety }\end{array}$ & $\begin{array}{c}\text { Clear Roles } \\
\text { and } \\
\text { Responsibilities }\end{array}$ & $\begin{array}{c}\text { Competence } \\
\text { Commensurate } \\
\text { with } \\
\text { Responsibilities }\end{array}$ & $\begin{array}{l}\text { Balanced } \\
\text { Priorities }\end{array}$ & $\begin{array}{l}\text { Identification } \\
\text { of Safety } \\
\text { Standards } \\
\text { and } \\
\text { Requirements }\end{array}$ & $\begin{array}{c}\text { Hazard } \\
\text { Controls } \\
\text { Tailored to } \\
\text { Work } \\
\text { Being } \\
\text { Performed }\end{array}$ & $\begin{array}{l}\text { Operations } \\
\text { Authorization }\end{array}$ \\
\hline $\begin{array}{l}\text { - AA } \\
\text { - FS\&HM } \\
\text { Vol. I, Part } 2\end{array}$ & $\begin{array}{l}\text { - AA } \\
\text { - ES\&HM } \\
\text { Vol. I, Part } 2\end{array}$ & $\begin{array}{l}\text { - ES\&HM } \\
\text { Vol. I, Part 2, } \\
\text { and Vol. IV, } \\
\text { Part2 } \\
\text { - TPM }\end{array}$ & $\mathrm{N} / \mathrm{A} \bullet$ & $\begin{array}{l}\text { - AA } \\
\text { - ES\&HM } \\
\text { Vol. I, } \\
\text { Part 2 } \\
\text { - ES\&HM } \\
\text { Vol. III }\end{array}$ & $\begin{array}{l}\text { - ES\&HM } \\
\text { Vol. I, } \\
\text { Part } 2 \\
\text { - ES\&HM } \\
\text { Vol. III } \\
\text { - MIP }\end{array}$ & $\mathrm{N} / \mathrm{A}$ \\
\hline
\end{tabular}

Table 5. Perform Work Crosswalk.

\begin{tabular}{|c|c|c|c|c|c|c|}
\hline $\begin{array}{c}\text { Line } \\
\text { Management } \\
\text { Responsibilities } \\
\text { for Safety }\end{array}$ & $\begin{array}{c}\text { Clear Roles } \\
\text { and } \\
\text { Responsibilities }\end{array}$ & $\begin{array}{l}\text { Competence } \\
\text { Commensurate } \\
\text { with } \\
\text { Responsibilities } \\
\text { - }\end{array}$ & $\begin{array}{l}\text { Balanced } \\
\text { Priorities }\end{array}$ & $\begin{array}{l}\text { Identification } \\
\text { of Safety } \\
\text { Standards and } \\
\text { Requirements }\end{array}$ & $\begin{array}{c}\text { Hazard } \\
\text { Controls } \\
\text { Tailored to } \\
\text { Work } \\
\text { Being } \\
\text { Performed }\end{array}$ & $\begin{array}{l}\text { Operations } \\
\text { Authorization }\end{array}$ \\
\hline $\begin{array}{l}\text { - AA } \\
\text { - ES\&HM } \\
\text { Vol. I, Part } 2\end{array}$ & $\begin{array}{l}\text { - AA } \\
\text { - ES\&HM } \\
\text { Vol. I, Part } 2\end{array}$ & $\begin{array}{l}\text { - ES\&HM } \\
\text { Vol. I, Part 2, } \\
\text { and Vol. IV, } \\
\text { Part } 2\end{array}$ & $\mathrm{~N} / \mathrm{A}$ & $\mathrm{N} / \mathrm{A}$ & $\mathrm{N} / \mathrm{A}$ & $\begin{array}{l}\text { - AA } \\
\text { - ES\&HM } \\
\text { Vol. I, Part } 2\end{array}$ \\
\hline
\end{tabular}

Table 6. Feedback/Improvement Crosswalk

\begin{tabular}{|c|c|c|c|c|c|c|}
\hline $\begin{array}{c}\text { Line } \\
\text { Management } \\
\text { Responsibilities } \\
\text { for Safety }\end{array}$ & $\begin{array}{c}\text { Clear Roles } \\
\text { and } \\
\text { Responsibilities }\end{array}$ & $\begin{array}{c}\text { Competence } \\
\text { Commensurate } \\
\text { with } \\
\text { Responsibilities }\end{array}$ & $\begin{array}{l}\text { Balanced } \\
\text { Priorities }\end{array}$ & $\begin{array}{l}\text { Identification } \\
\text { of Safety } \\
\text { Standards and } \\
\text { Requirements }\end{array}$ & $\begin{array}{c}\text { Hazard } \\
\text { Controls } \\
\text { Tailored to } \\
\text { Work Being } \\
\text { Performed }\end{array}$ & $\begin{array}{l}\text { Operations } \\
\text { Authorization }\end{array}$ \\
\hline $\begin{array}{l}\text { - AA } \\
\text { - ES\&HM } \\
\text { Vol. I, Part } 2 \\
\text { - SAP } \\
\text { - QA P } \\
\text { - FIP }\end{array}$ & $\begin{array}{l}\text { - AA } \\
\text { - ES\&HM } \\
\text { Vol. I, Part } 2 \\
\text { - SAP } \\
\text { - QAP } \\
\text { - FIP }\end{array}$ & $\begin{array}{l}\text { ES\&HM } \\
\text { Vol. I, Part 2, } \\
\text { and Vol. IV, } \\
\text { Part } 2 \\
\text { - SAP }\end{array}$ & $\mathrm{N} / \mathrm{A}$ & $\mathrm{N} / \mathrm{A}$ & $N / A$ & $\mathrm{~N} / \mathrm{A}$ \\
\hline
\end{tabular}




\subsection{Integration of Core Functions Throughout Organizational Levels}

The core functions are integrated vertically throughout all levels from the Superblock level, to the facility level, to the activity level, as shown in Figure 4 . The boxes in the figure contain key information, processes, or requirements associated with each core function at a given organizational level. Detailed information for the facility and the activity levels is given in the appendices for the respective facilities.

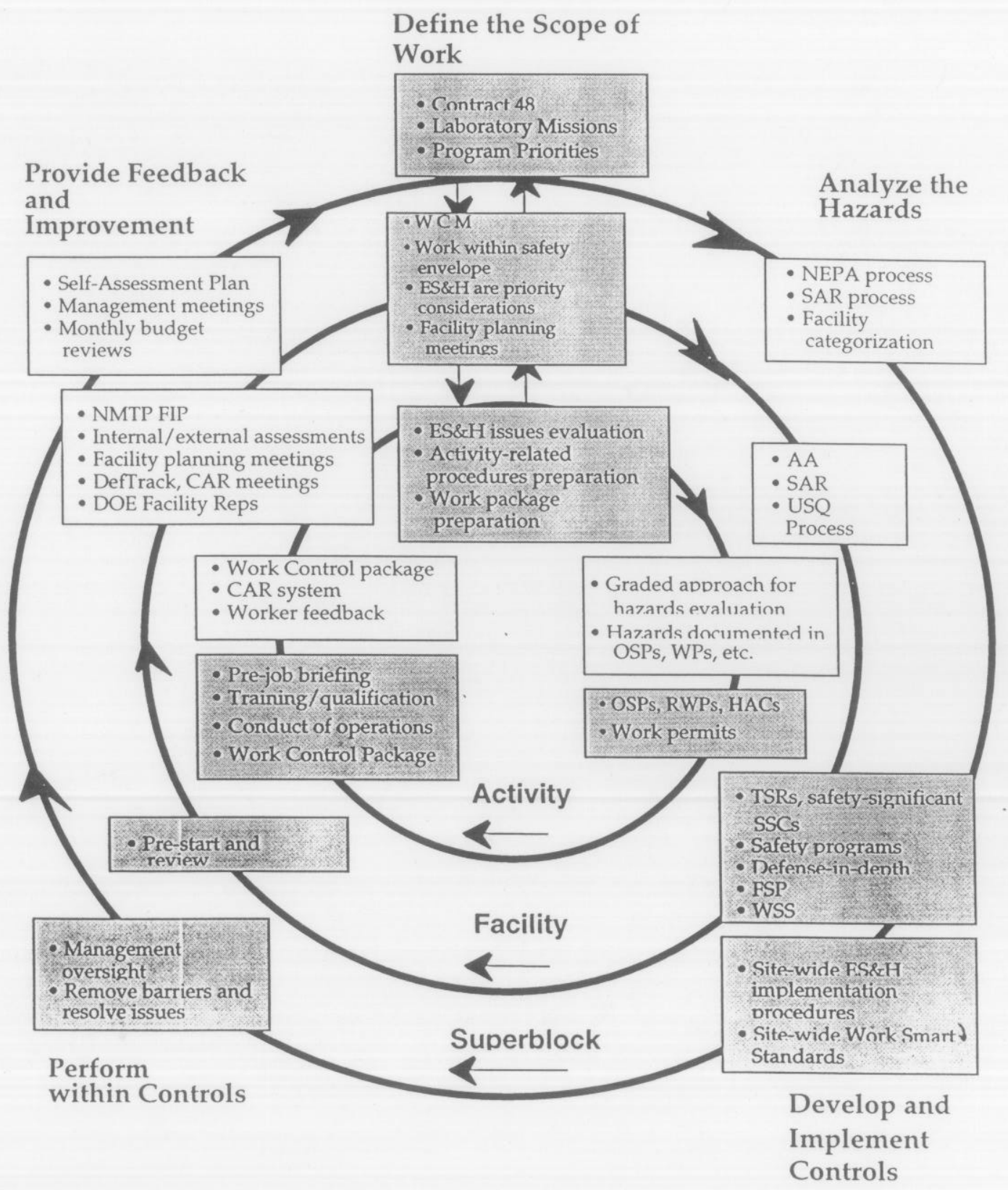

Figure 4. Interactions between all levels (i.e., Superblock, facility, and activity) for the five core functions. 
This page intentionally left blank. 


\subsection{Program and Budget Execution Guidance}

The Superblock is supported by three types of funding: (1) DNT programmatic funding, (2) general and administrative (G\&A) funding, and (3) facility users' fees. Programmatic funding is allocated from the DNT budget. The G\&A funding is allocated by the institution through the review of the Laboratory G\&A Funding Review Committee. The users' fees are usually determined through negotiations between the NMT Program. Leader and program users at the beginning of each fiscal year. A specific responsibility of the NMT Program Leader, through his deputies, is to ensure that all programmatic work in the Superblock conforms to DOE program guidance and ES\&H requirements.

Programmatic funding and users' fees generally cover costs associated with maintenance and surveillance for facility-related equipment. It also pays for the services provided by the ES\&H Team 1 and Criticality Safety Engineers. In addition, programmatic funding also supports activities related to security and safeguards (i.e., materials management and the guard force) required for the Superblock. The G\&A funding and users' fees provide supplemental funding for baseline operations for the Superblock facilities and the Materials Management Section including manpower charges from key facility staff and administrative personnel.

In recent years, both $\mathrm{B} 331$ and $\mathrm{B} 332$ have received all three types of funding, while B334 has been supported only by the DNT programmatic funding because of the relatively small size of its operations.

The NMT Program Leader conducts annual budget reviews for Superblock activities. Discussions of priority regarding ES\&H requirements are included in the review. With the input from the Superblock organizations, the NMT Program Leader prepares and submits a detailed annual budget plan (including baseline operations, ES\&H requirements) to the $\mathrm{AD} / \mathrm{DNT}$ Office for review. A formal presentation to the AD/DNT is required before the DNT programmatic funding is approved.

In addition to the funding described above, the Superblock also requests funding through the AD/DNT Office for the General Plant Projects (GPP) and Construction Line Item Funding. These funds, when approved, are generally used to upgrade safety structures, systems, and components (SSSCs) for the facilities. 
This page intentionally left blank. 


\subsection{Standards and Requirements}

In 1997, the Laboratory and DOE/OAK inaugurated a "Work Smart Standards" process, as opposed to the Standards/Requirements Identification process, whereby safety professionals from both organizations work with Livermore researchers to identify hazards and establish standards of operation appropriate for the particular work environment. The Work Smart Standards (WSS) process identified and selected a set of ES\&H standards directly applicable to the Laboratory's work. The WSS set was approved August 5, 1999, and is incorporated into Appendix G of Contract 48. The Superblock is in the process of evaluating and reconciling the interim WSS of the Authorization Agreement (AA) with the WSS approved site-wde. The final outcome, as described in Section 13.0, will be a revised AA for each Superblock facility that includes the site-wide WSS.

The WSS process teams, composed of members from DOE, UC, and LLNL, define the work, identify the associated hazards, and select the appropriate standards set. When the three parties approve the set of standards, the set is incorporated into the contract. The Laboratory then integrates the standards with the lessons learned through years of operation into its ES\&H manuals and other ES\&H documents. These documents are used as the basis for implementing ISMS at LLNL.

For the Superblock facilities, it is acknowledged in the Authorization Agreements that requirements cited in the SAR and the TSR documents for each Superblock facility as approved by DOE/OAK, and any conditions specified in the DOE Safety Evaluation Report, constitute the interim WSS. Each Appendix of this document includes an Attachment A listing the present orders and standards that are both interim WSS for the facility and in Appendix G of Contract 48 . The interim WSS will be reconciled as the WSS are implemented by the institution. When DOE, LLNL, and UC reach agreement on a set of standards, it is incorporated into the contract. Detailed process, milestones, and schedule for this reconciliation are addressed in Sections 13.0 and 14.0. Section 11.0 below contains a table citing what the requirements are and the LLNL institutional documents and others followed at the Superblock level to satisfy the cited requirements. The detailed set of standards and requirements at the facility and activity levels are contained in the individual facility Appendices. 
This page intentionally left blank. 


\subsection{Evaluating and Resolving Non-Compliances}

Under the provisions of Appendix F, Contract 48, the Laboratory conducts an annual self-assessment to evaluate its management performance in several administrative and operational areas, including ES\&H. The ES\&HM, Volume I, Part 4, provides the guidance for establishing ES\&H self-assessment programs at the Directorate level. Also, the ES\&HM, Volume I, Part 5, describes the process for tracking ES\&H-related deficiencies. Where necessary, corrective action plans are developed to address any significant ES\&H management deficiencies that the self-assessment may disclose. The status and closure of these corrective actions are tracked on a computer-based system called the LLNL Deficiency Tracking (DefTrack) system. The Laboratory's deficiency tracking system was established to track the status of ES\&H deficiencies from the time they are identified until they are resolved.

Based on the above guidelines, Superblock management provides the input every two years to the DNT ES\&H Self-Assessment Plan, which is being followed and executed by the Superblock. The plan consists of three assessment elements:

- Surveys are scheduled, including topical or general, facility, and system/activity reviews. Specific topics may include industrial safety, fire protection, radiation safety, lockout and tag program, training, equipment calibration, etc.

- Inspections are scheduled, including DNT facility evaluations, and provide formal comprehensive evaluation of compliance to codes, standards, and regulations. These inspections may be conducted by outside organizations or internal inspection teams.

- Audits-i.e., formal reviews of projects', programs', facilities' ES\&H and/or QA activities-are performed. These are planned and documented evaluations to determine the adequacy of compliance with established procedures, and are performed using investigation, examination, or evaluation of objective evidence. Audits may also be conducted by a committee selected by the DNT Assurance Manager.

Formal surveys, inspections, and audits are required to be documented and to be entered into DefTrack. DNT management requires that Occurrence Report corrective actions, judgments of need (if Incident Analysis reports), and PAAA non-compliance issues be entered into DefTrack. Informal facility walkthroughs and self-assessments may be tracked by an internal tracking system for closure or entered into DefTrack when directed by facility management.

The deficiency priority scale identified in the DefTrack system is defined as follows:

- Priority 1A-Imminent danger, severe impact, or catastrophic loss.

- Priority 1B-Substantial danger, impact, or major loss.

- Priority 2-Significant hazard, impact, or loss.

- Priority 3-Minor hazard, impact, or loss. 
- Priority 4-Minimum or no consequence.

In accordance with the DNT ES\&H Self-Assessment Plan (dated January 1998), the DNT Assurance Office is required to roll up deficiencies at the end of month to the Assurance Review Office for inclusion in the Laboratory-wide DefTrack database for all deficiencies identified by external appraisals and formal assessments. The NMT Program Leader is responsible for validating the current deficiency status in the DNT DefTrack database on a quarterly basis and providing an update to the DNT Assurance Office.

The deficiencies identified in operations and facilities during self-assessments and during audits, reviews, and appraisals by Laboratory and external oversight entities are reviewed by the Superblock FMs to determine appropriate corrective actions. The objective of this process is to improve safety in the workplace and compliance with ES\&H requirements. Line management assigns responsibility for implementing actions to correct self-assessment deficiencies and uses the deficiency-tracking system to monitor the status until the actions are completed and verified. Findings and recommendations from appraisals, audits, and reviews of operations are documented in reports and put into the deficiency-tracking system where appropriate. In response to the findings and recommendations, management develops action plans to correct the identified operational and management problems. The plans include schedules for completing the corrective actions and provide for regular reporting to the agency or office that conducted the appraisal until all deficiencies are closed out.

The ES\&HM, Volume I, Part 5, contains a description of the Laboratory's incident analysis process and follow-up requirements. Corrective action plans may also be developed as a result of the analysis of immediate, contributing, and root causes of DOE-reportable occurrences. The primary objective in formally reviewing incidents, accidents, and other occurrences is to prevent the recurrence of the event and to reduce risk in a specific operation or facility. 


\subsection{Flowdown of Requirements}

In performing work under DOE/UC Contract 48 (CLAUSE 5.5 - DEAR 970.5204-78), the Laboratory is contractually bound to comply with applicable federal, state, and local laws, regulations, and the requirements of those DOE Directives, ${ }^{2}$ or parts (identified in Appendix G, DOE Directives of the Contract). Table 7 presents the flowdown of requirements to which the Superblock is committed to reconcile as part of the WSS process. In the first column, those relevant requirements (those contained in Appendix G of DOE/UC Contract 48 and some nuclear safety rules) to the Superblock are listed. The second column lists LLNL documents and others that are developed to be in compliance with these requirements that the Superblock follows. At the Superblock facility level, when required, each facility will develop additional plans, procedures, or policies to deal with these requirements directly or indirectly, as necessary. Their details are contained in the Appendices of this document. Flowdown of work control requirements to personnel supporting Superblock facilities, or personnel under memoranda of agreement, or subcontractors doing work within the facilities, is accomplished by requiring that they satisfy the same work control requirements as facility workers. See the WCMs, Section 1.0. The WCMs explicitly include all work within the facilities.

Table 7. Flowdown of requirements for the Superblock level.

\begin{tabular}{|c|c|}
\hline Requirements & $\begin{array}{l}\text { Relevant LLNL documents or requirements } \\
\text { that the Superblock follows }\end{array}$ \\
\hline $\begin{array}{l}\text { DOE Order 232.1A, } \\
\text { Occurrence Reporting and } \\
\text { Processing of Operations } \\
\text { Information }\end{array}$ & $\begin{array}{l}\text { - LLNL Implementing Procedures for DOE Order 232.11, } \\
\text { Occurrence Reporting and Processing of Operations } \\
\text { Information } \\
\text { - Defense and Nuclear Technologies Occurrence Reporting } \\
\text { Protocol }\end{array}$ \\
\hline $\begin{array}{l}\text { DOE Order } 420.1 \text {, Facility } \\
\text { Safety }\end{array}$ & $\begin{array}{l}\text { - LLNL ESEHM: } \\
\text {-Volume II, Part 8, "Ionizing, Non-Ionizing Radiation" } \\
\text { - Volume II, Part 10, "Emergencies, Earthquakes, Fire" } \\
\text { - LLNL Fire Protection Program, UCRL-MA } 116646 \\
\text { - I.LNI. Fire Protection Engineering Standards }\end{array}$ \\
\hline $\begin{array}{l}\text { DOE Order } 440.1 \mathrm{~A}, \text { Worker } \\
\text { Protection Management for } \\
\text { DOE Federal and } \\
\text { Contractor Employees }\end{array}$ & $\begin{array}{l}\text { - LLNL ESEHM: } \\
\text {-Volume II, Part 2, "Chemical" } \\
\text {-Volume II, Part 12, "General Controls - Procedures" } \\
\text {-Volume IV, Part 1, "Occupational Health" } \\
\text {-Volume IV, Part 2, "Training" }\end{array}$ \\
\hline $\begin{array}{l}\text { DOE Order } 4330.4 \mathrm{~B} \text {. } \\
\text { Maintenance Management } \\
\text { Program }\end{array}$ & $\begin{array}{l}\text { - LLNL Maintenance Implementation Plan for Nonreactor } \\
\text { Nuclear Facilities }\end{array}$ \\
\hline $\begin{array}{l}\text { DOE Order } 5400.1, \text { General } \\
\text { Environmental Protection } \\
\text { Program }\end{array}$ & - LLNL ESEHM, Volume III \\
\hline $\begin{array}{l}\text { DOE Order 5480.1B (Ch. 5), } \\
\text { Environmental, Safety and } \\
\text { Health Program }\end{array}$ & - LLNL ESEHM \\
\hline
\end{tabular}

0

2 "DOE Directive" means those DOE Orders, Notices, Manuals, Guides, Standards, and other Contracting Officer directions that are referred to in Appendix G, List of Applicable Directives. 
Table 7. Flowdown of requirements for the Superblock level. (continued)

\begin{tabular}{|c|c|}
\hline Requirements & $\begin{array}{c}\text { Relevant LLNL documents or requirements } \\
\text { that the Superblock follows }\end{array}$ \\
\hline $\begin{array}{l}\text { DOE Order } 5480.3, \text { Safety } \\
\text { Requirements for the } \\
\text { Packaging and } \\
\text { Transportation of } \\
\text { Hazardous Materials }\end{array}$ & $\begin{array}{l}\text { - LLNL Onsite Hazardous Materials Packaging and } \\
\text { Transporlalion Safely Manual } \\
\text { - LLNL HMPTS Quality Assurance Plan }\end{array}$ \\
\hline $\begin{array}{l}\text { DOE Order } 5480.4 \text { (Ch. } 4) \text {, } \\
\text { Environmental Protection, } \\
\text { Safety and Health } \\
\text { Protection Standards }\end{array}$ & - LLNL ESEHM \\
\hline $\begin{array}{l}\text { DOE Order } 5480.19(\mathrm{Ch} .1), \\
\text { Conduct of Operations } \\
\text { Requirements for DOE } \\
\text { Facilities }\end{array}$ & $\begin{array}{l}\text { - LLNL ESEHM, Volume 1, Part 2, "ES\&H Management } \\
\text { Requirements" }\end{array}$ \\
\hline $\begin{array}{l}\text { DOE Order 5480.20A, } \\
\text { Personnel Selection, } \\
\text { Qualification, and Training } \\
\text { Requirements for DOE } \\
\text { Nuclear Facilities }\end{array}$ & $\begin{array}{l}\text { - LLNL ESEHM: } \\
\text {-Volume 1, Part 2, "ES\&H Management Requirements" } \\
\text {-Volume V, Part 1, "Personnel" } \\
\text { - LLNL Defense Systems/Nuclear Design Directorate Training } \\
\text { Plan }\end{array}$ \\
\hline $\begin{array}{l}\text { DOE Order } 5480.21 \\
\text { Unreviewed Safety } \\
\text { Questions }\end{array}$ & $\begin{array}{l}\text { - LLNL ESEHM: } \\
\text {-Volume 1, Part 2, "ES\&H Management Requirements" } \\
\text {-Volume V, Part 2, "Procedures" }\end{array}$ \\
\hline $\begin{array}{l}\text { DOE Order } 5480.22 \text { (Ch. 1), } \\
\text { Technical Safety } \\
\text { Requirements }\end{array}$ & $\begin{array}{l}\text { - LLNL ESEHM: } \\
\text {-Volume 1, Part 2, "ES\&H Management Requirements" } \\
\text {-Volume V, Part 2, "Procedures" }\end{array}$ \\
\hline $\begin{array}{l}\text { DOE Order } 5480.23(\mathrm{Ch} .1) \\
\text { Nuclear Safety Analysis } \\
\text { Report }\end{array}$ & $\begin{array}{l}\text { - LLNL ESEHM: } \\
\text {-Volume 1, Part 2, "ES\&H Management Requirements" } \\
\text { - -Volume V, Part 2, "Procedures" } \\
\text { - DOE-STD-3009, Preparation Guide for U.S. DOE Nonreactor } \\
\text { Nuclear Facility Safety Analysis Reports } \\
\text { - DOE-STD-1027, Guidance on Preliminary Hazard } \\
\text { Classification and Accident Analysis Techniques for Compliance } \\
\text { with DOE 5430.23 Nuclear Safety Analysis Report } \\
\text { - DOE-STD-1104, Guidance on Preliminary Hazard } \\
\text { Classification and Accident Review and Approval of Nonreactor } \\
\text { Nuclear Facility Safety Analysis Report }\end{array}$ \\
\hline $\begin{array}{l}\text { DOE Order } 5480.31, \text { Startup } \\
\text { and Restart of Nuclear } \\
\text { Facilities }\end{array}$ & $\begin{array}{l}\text { - LLNL ESEHM: } \\
\text {-Volume 1, Part 2, "ES\&H Management Requirements" } \\
\text {-Volume V, Part 5, "Facilities" }\end{array}$ \\
\hline $\begin{array}{l}\text { DOE Order 5482.1B, } \\
\text { Environment, Safety, and } \\
\text { Health Appraisal Program }\end{array}$ & $\begin{array}{l}\text { - LLNL ESEHM: } \\
\text {-Volume 1, Part 2, "ES\&H Management Requirements" } \\
\text {-Volume I, Part 5, "Feedback and Improvement" } \\
\text {-Volume II, Part 12, "General Controls - Procedures" } \\
\text { - DNT Environmental, Safety and Health Self-Assessment Plan } \\
\text { (continued next page) }\end{array}$ \\
\hline
\end{tabular}


Table 7. Flowdown of requirements for the Superblock level. (continued)

\begin{tabular}{|c|c|}
\hline Requirements & $\begin{array}{l}\text { Relevant LLNL documents or requirements } \\
\text { that the Superblock follows }\end{array}$ \\
\hline $\begin{array}{l}\text { DOE Order 5484.1, } \\
\text { Environmental Protection, } \\
\text { Safety, and Health } \\
\text { Information Reporting } \\
\text { Requirements }\end{array}$ & $\begin{array}{l}\text { - LLNL ESEHM: } \\
\text {-Volume I, Part 5, "Feedback and Improvement" } \\
\text {-Volume II, Part 10, "Emergencies, Earthquakes, Fire" }\end{array}$ \\
\hline $\begin{array}{l}\text { DOF Order 5633.3B, } \\
\text { Control and Accountability } \\
\text { of Nuclear Materials }\end{array}$ & $\begin{array}{l}\text { - LLNL Nuclear Materials Controls and Accountability Control } \\
\text { Manual }\end{array}$ \\
\hline $\begin{array}{l}\text { DOE Order } 5820.2 \mathrm{~A} \\
\text { Radioactive Waste } \\
\text { Management }\end{array}$ & $\begin{array}{l}\text { - LLNL Waste Acceptance Criteria } \\
\text { - LLNL TRU Waste Program Certification and Quality } \\
\text { Assurance Plan } \\
\text { - LLNL Low-Level Waste Program Certification and Quality } \\
\text { Assurance Plan } \\
\text { - LLNL Guidelines for Waste Accumulation Area } \\
\text { - Defense \& Nuclear Technologies Directorate Waste } \\
\text { Minimization and Pollution Prevention Plan } \\
\end{array}$ \\
\hline $\begin{array}{l}\text { 10 CFR } 830.120, \text { Quality } \\
\text { Assurance } \\
\text { DOE Order 5700.6C, } \\
\text { Quality Assurance }\end{array}$ & $\begin{array}{l}\text { - LLNL Quality Assurance Program } \\
\text { - Defense and Nuclear Technologies Directorate Quality } \\
\text { Assurance Plan } \\
\text { - Defense and Nuclear Technologies Directorate Calibration } \\
\text { Program for Measuring and Test Equipment }\end{array}$ \\
\hline $\begin{array}{l}\text { 10 CFR 835: Occupational } \\
\text { Radiation Protection } \\
\text { DOE Order } 5400.5 \text { (Ch. 2), } \\
\text { Radiation Protection of the } \\
\text { Public and the } \\
\text { Environment }\end{array}$ & $\begin{array}{l}\text { - LLNL ESEHM: } \\
\text {-Volume II, Part 8, "Ionizing, Non-Ionizing Radiation" } \\
\text { - Volume II, Part 10, "Emergencies, Earthquakes, Fire" }\end{array}$ \\
\hline
\end{tabular}


This page intentionally left blank. 


\subsection{ISMS Description Change Control Process}

The Superblock is committed to performing work in conformance with the ISMS as described in this document. This document is written to satisfy the DOE/OAK Contracting Officer's directive issued in accordance with the Department of Energy Acquisition Regulation (DEAR) clause as incorporated into DOE/UC Contract 48. After DOE/OAK has approved this document, any changes that would affect the objective, principles, or functions must be approved by DOE/OAK. The Superblock may make editorial changes, and other minor changes that do not affect the intent of the approved ISMS Description, without DOE/OAK approval. Upon reconciliation with the LLNL ISMS Description, the Superblock ISMS Description will be subsumed into the DNT ISMS Implementation Plan and changes will be controlled as for all other DNT facilities.

As Contract requirements and external requirements change, it is recognized that the Superblock, upon LLNL's acceptance or recognition of the change, will annually have the ISMS Description document reviewed against the results of any operation-related assessments and the associated corrective actions, and will take one of the following actions:

- Submit a total revision of the ISMS Description for DOE/OAK approval.

- Submit page revisions of the ISMS Description for DOE/OAK approval.

- Submit page revisions of the ISMS Description for DOE/OAK information.

- Submit a letter to DOE/OAK indicating no change to the ISMS Description. 
This page intentionally left blank. 


\subsection{Reconciliation of Superblock ISMS with Site-wide ISMS}

This section addresses issues associated with reconciliation of the Superblock ISMS Description with the Site-wide ISMS Description, as required in the DOE/OAK Guidance Letter of August 18, 1998, on preparation, content, review, and approval of the LLNL Descriptions.

The Superblock consists of one Nuclear Hazard Category 2 facility (Building 332) and two Category 3 nuclear facilities (Buildings 331 and 334). In 1996, the Superblock ${ }^{3}$ was identified as one of ten priority facilities in the DOE complex in the DOE's Implementation Plan in response to the DNFSB's Recommendation 95-2. Thus, the Superblock started implementing the ISMS concept earlier than the rest of the Laboratory.

Therefore, as delineated in the DOE/OAK ISMS Guidance Letter of August 18, 1998, the approach to ISMS at LLNL was to separate the ISMS development and implementation for the Superblock from the site-wide process with the intention that the two would be reconciled into one system at a later date. Inconsistencies between the Superblock and LLNL primarily relate to the WSS. AAs for Superblock facilities refer to interim WSS identified in the facilities' SARs and TSRs that differ somewhat from the LLNL WSS. Differences between them and the LLNL WSS have been identified. Section 14.0, below, shows the Superblock's planned date for reconciling the interim WSS with the LLNL WSS. Where orders and standards in the facility SARs have been updated, cancelled, or otherwise superceded, each facility will perform USQ evaluations to confirm the integrity of its authorization basis.

\footnotetext{
${ }^{3}$ The reference is to the Plutonium Facility-Building 332.
} 
This page intentionally left blank. 


\subsection{Implementation Tasks, Schedule, and Milestones}

Per the DOE/OAK Guidance Letter of August 18, 1998, on preparation, content, review, and approval of the LLNL Descriptions, the following schedule and milestones relevant to the Superblock ISMS Description are given:

- Incorporate DOE/OAK comments and fill gaps in the Superblock ISMS Description. (October 29, 1999)

- Reconciliation of Site-wide ISMS and Superblock Nuclear Facilities' ISMS. (Superblock Management will provide reconciliation plan within three months after Site-wide Phase II Verification.)

- Reconciliation of LLNL WSS and Superblock Nuclear Facilities' interim WSS. (June 2000) 
This page intentionally left blank. 


\subsection{Conclusions}

This section summarizes the approach taken in the compilation and verification of the Superblock ISMS Description and addresses the issue of reconciliation of the Superblock ISMS Description with the Site-wide ISMS Description.

As delineated in the DOE/OAK Guidance Letter of August 18, 1998, on preparation, content, review, and approval of the LLNL Descriptions, the approach to ISMS at LLNL is to separate the ISMS development and implementation for the Superblock from the Site-wide process with the intention that the two will subsequently be reconciled into one system by the middle of CY 2000.

The Superblock ISMS Description is composed of four parts: the overall Superblock ISMS Description and three appendices, one for each of the three nuclear facilities (Buildings 331, 332, and 334) included in the Superblock. 
This page intentionally left blank. 


\subsection{References}

Development of the Superblock ISMS Description is based on the following references:

- Letter from R. Promani (DOE/OAK) to D. Fisher (LLNL), “Contract No. W-7405ENG-48, Clause 6.7, Contracting Officer Guidance on Integrated Safety Management System (ISM)S) Description Document Development and Implementation," dated August 18, 1998.

- Letter from P. Hill (DOE/OAK) to J. Sefcik (NMTP/DNT/LLNL), "OAK Comments on Superblock ISMS Description and Appendix A," dated February 24, 1999.

- Letter from P. Hill (DOE/OAK) to J. Sefcik (NMTP/DNT/LLNL), "DOE/OAK Comments on Superblock Description, Appendices B and C," dated March 8, 1999.

- Letter from M. Hooper (DOE/OAK) to M. Anastasio (AD, DNT, LLNL), "DOE/OAK Comments on Superblock ISMS Description, Rev. 1, May 1999," dated August 24, 1999.

- Letter from J. Winter, (DP-45), Team Leader, to J. Turner and M. Hooper (DOE/OAK), "ISMS Verification for LLNL at Superblock, Phase I and II," dated September 30, 1999.

- DOE G 450.4-1, “Integrated Safety Management System Guide for Use with DOE P 450.4, Safety Management System Policy; and DEAR Safety Management System Contract Clauses," dated November 26, 1997.

- Contract Clause 6.7, DEAR 970.5204-2, "Integration of Environment, Safety, and Health into Work Planning and Execution," June 1997.

- Contract Clause 5.5, DEAR 970.5204-78, “Laws, Regulations, and DOE Directives," dated June 1997.

- DOE-HDBK-XXX-97, "Integrated Safety Management Systems Verification (ISMSV) Process Team Leader's Handbook," September 1997.

- ISMS Phase I/II Verification at the Superblock, Volumes I and II, September 1999.

- DOE P 450.4, "Safety Management System Policy," dated October 15, 1996.

- DNFSB/TECH-16, "Integrated Safety Management," June 1997. J

- DNFSB/TECH-19, "Authorization Agreements for Defense Nuclear Facilities and Activities," April 1998.

- UCRL-AR-132791, LLNL Integrated Safety Management System Description, Version 2.0, October 1999. 
This page intentionally left blank. 


\subsection{Acronyms}

\begin{tabular}{|c|c|}
\hline AA & Authorization Agreement \\
\hline ACGIH & American Conference of Governmental Industrial Hygienists \\
\hline $\mathrm{ACP}$ & Administrative Control Procedure \\
\hline $\mathrm{AD}$ & Associate Director \\
\hline ALARA & As Low As Reasonable Achievable \\
\hline ANS & American Nuclear Society \\
\hline ANSI & American National Standards Institute \\
\hline $\mathrm{ARO}$ & Assurance Review Office \\
\hline ASHRAE & $\begin{array}{l}\text { American Society of Heating, Refrigeration, and } \\
\text { Air-Conditioning Engineers }\end{array}$ \\
\hline ASME & American Society of Mechanical Engineers \\
\hline BAAQMD & Bay Area Air Quality Management District \\
\hline BSS & Building Safety System \\
\hline CAM & Continuous Air Monitor \\
\hline CAR & Corrective Action Request \\
\hline CAS & Criticality Alarm System \\
\hline CSE & Criticality Safety Engineer \\
\hline DAP & Discipline Action Plan \\
\hline DAS & Daily Activity Scheduling \\
\hline DCP & Design Change Package \\
\hline DNT & Defense \& Nuclear Technologies (Directorate) \\
\hline DOE & Department of Energy \\
\hline DefTrack & LLNL Deficiency-Tracking Database \\
\hline DOE & U.S. Department of Energy \\
\hline EIS/EIR & Environmental Impact Statement/Environmental Impact Report \\
\hline EPA & Environmental Protection Agency \\
\hline EPD & Environmental Protection Department $\ldots .$. \\
\hline ERDA & Energy Research and Development Administration \\
\hline ES\&H & Environmental Safety and Health \\
\hline ES\&HM & LLNL Environmental, Safety and Health Manual \\
\hline ETB & Engineering Test Box \\
\hline FEDR & Facility Engineering Design Review \\
\hline FEDRC & Facility Engineering Design Review Committee \\
\hline FIP & NMTP Feedback and Improvement Program \\
\hline FM & Facility Manager \\
\hline FMH & Fissile Material Handler \\
\hline FOMM & Facility Operations and Maintenance Manager \\
\hline FOP & Facility Operating Plan \\
\hline FORR & Facility Operational Readiness Review \\
\hline FSO & Facility Safety Officer \\
\hline FSP & Facility Safety Plan \\
\hline FTM & Facility Training Manager \\
\hline G\&A & General and Administrative \\
\hline GOCO & Government-owned Contractor-operated \\
\hline
\end{tabular}




\begin{tabular}{|c|c|}
\hline GPP & General Plant Projects \\
\hline $\mathrm{HC}$ & Hazards Control \\
\hline $\mathrm{HCD}$ & Hazards Control Department \\
\hline HEPA & High-Efficiency Particulate Air \\
\hline HW & Hazardous Waste \\
\hline HWMFT & Hazardous Waste Management Field Technician \\
\hline IEEE & Institute of Electronic and Electrical Engineers \\
\hline IH & Industrial Hygiene \\
\hline ISMS & Integrated Safety Management System \\
\hline $\mathrm{LCO}$ & Limiting Conditions for Operation \\
\hline LLNL & Lawrence Livermore National Laboratory \\
\hline LLW & Low-Level Waste \\
\hline LTRAIN & Livermore Training Requirements and Information Network \\
\hline MC\&A & Materials Control and Accountability \\
\hline MAD & Master Action Database \\
\hline MIP & Maintenance Implementation Plan \\
\hline MOU & Memorandum of Understanding \\
\hline NESHAPS & National Emission Standards for Hazardous Air Pollutants \\
\hline NFPA & National Fire Protection Association \\
\hline NMTP & Nuclear Materials Technology Program \\
\hline NRC & Nuclear Regulatory Commission \\
\hline $\mathrm{OP}$ & Operating Procedure \\
\hline OSP & Operational Safety Plan \\
\hline PAAA & Price-Anderson Amendment Act \\
\hline PAS & Passive Air Sampler \\
\hline PKE & Process Knowledge Evaluation \\
\hline POCM & Performance Objectives, Criteria, and Measures \\
\hline PPE & Personal Protection Equipment \\
\hline QA & Quality Assurance \\
\hline QAC & Quality Assurance Coordinator \\
\hline QAE & Quality Assurance Engineer \\
\hline QAP & Quality Assurance Plan \\
\hline QIP & Quality Implementation Plan \\
\hline $\mathrm{QM}$ & Quality Management \\
\hline QOP & Quality Operating Procedure \\
\hline QSB & Quarterly Safety Briefing \\
\hline $\mathrm{RI}$ & Responsible Individual \\
\hline RMA & Radioactive Materials Area \\
\hline S\&S & Safeguards and Security \\
\hline SAP & DNT Self-Assessment Plan \\
\hline SAR & Safety Analysis Report \\
\hline SCSSC & Safety-Class Structures, Systems, and Components \\
\hline SER & Safety Evaluation Report \\
\hline SNM & Special Nuclear Material \\
\hline SR & Surveillance Requirement \\
\hline SRP & Surveillance Requirement Procedure \\
\hline SSC & Structures, Systems, and Components \\
\hline SSSSC & Safety-Significant Structures, Systems, and Components \\
\hline TAC & Training Advisory Committee \\
\hline
\end{tabular}


TIM

TRU

TSR

UC

USQ

WAA

WCM

WIPP

WMPP

WP

WSS
Training Implementation Matrix

Transuranic

Technical Safety Requirement

University of California

Unreviewed Safety Question

Waste Accumulation Area

Work Control Manual or Work Control/Design Change Control Process

Manual

Waste Isolation Pilot Plant

Waste Minimization and Pollution Prevention

Work Permit

Work Smart Standards 
This page intentionally left blank. 


\section{APPENDIX A}

\section{Integrated Safety Management System (ISMS) \\ for \\ Building 332}

October 1999

Rev. 2 


\section{About This Appendix}

Sections 1.0 through 5.0,12.0, and 13.0 of the Superblock Integrated Safety Management System Description, of which this appendix forms a part, covers the topics of those sections sufficiently for B332 as to make their further inclusion in this appendix redundant. This appendix, therefore, is composed of Sections 6.0,7.0, 8.0, 9.0, 10.0, 11.0, and 14.0, corresponding to those sections of the main document but providing details specific to B332. It also includes Attachment A, Plutonium Facility Work Smart Standards Reconciliation, which provides a comparison to the LLNL Work Smart Standards per the UC/DOE Contract Appendix G.

This document is to be used concurrently with the LLNL ISM System Description (Version 2.0, dated October 1, 1999), and the Work Smart Standards (from Contract 48 Appendix G). The Facility's Orders and Standards per the current Authorization Agreement and Work Smart Standards set as stated herein will match the institutional set with the issuance of the institution's associated implementing manuals and guidance after the reconciliation process. 


\section{TABLE OF CONTENTS}

6.0 Safety Management System Mechanisms ................................................................

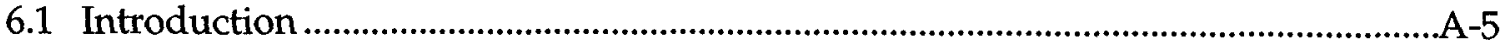

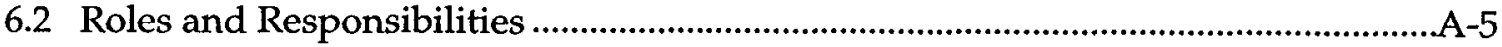

6.2.1 Line Management Responsibility for Safety …..............................................

6.2.2 Clear Roles and Responsibilities ................................................................

6.2.3 Competence Commensurate with Responsibilities ....................................A-7

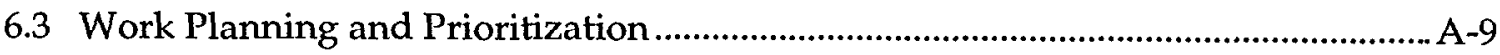

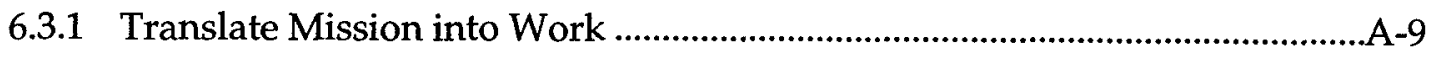

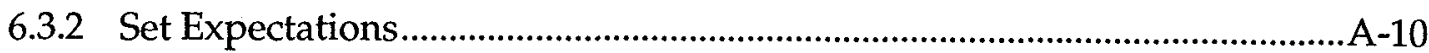

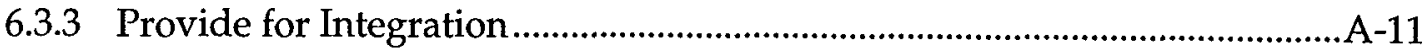

6.3.4 Prioritize Tasks and Allocate Resources ........................................................ A-13

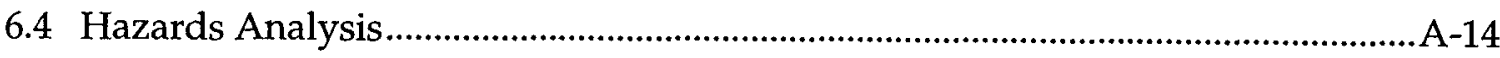

6.4.1 Identify and Analyze Hazards ............................................................... A-14

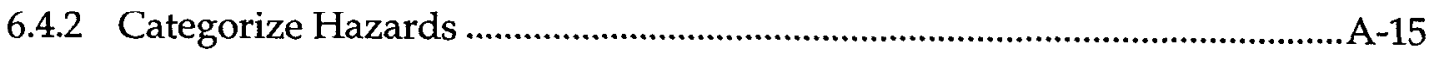

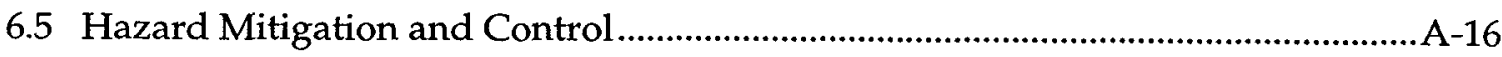

6.5.1 Identify Standards and Requirements ........................................................

6.5.2 Identify Controls to Prevent/Mitigate Hazards .........................................16

6.5.3 Establish and Implement Safety Controls ..................................................18

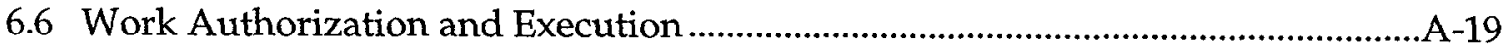

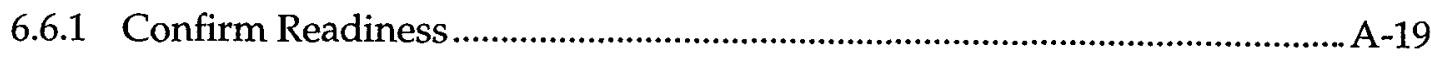

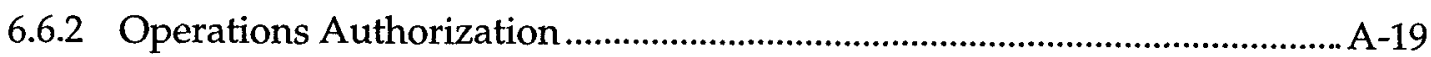

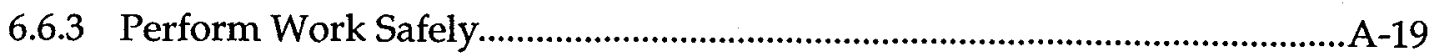

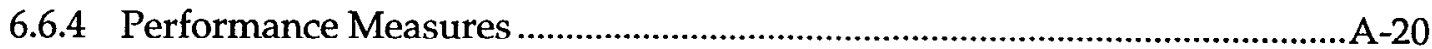

6.7 Performance Monitoring and Improvement.........................................................20

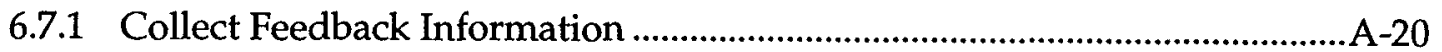

6.7.2 Identify Improvement Opportunities and Make Changes to Improve......A-21

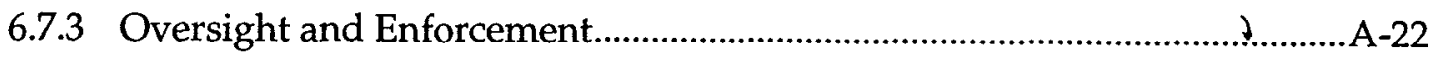

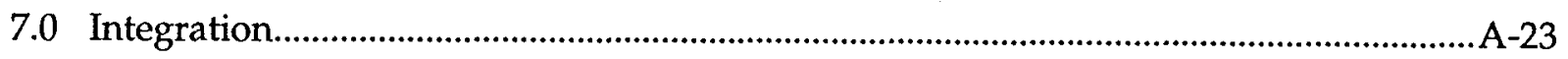

8.0 Program and Budget Execution Guidance ...................................................................27

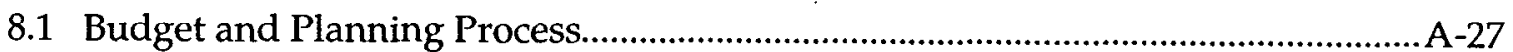

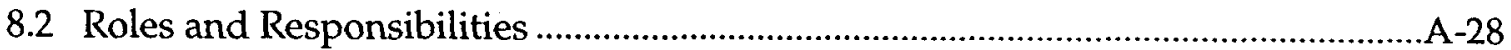

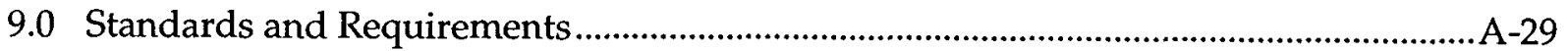

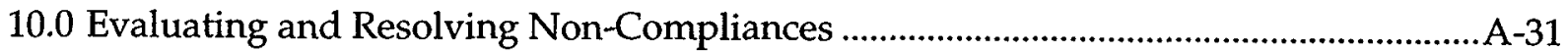


14.0 Implementation Tasks, Schedule, and Milestones .......................................................A-37

Attachment A Plutonium Facility Work Smart Standards Reconciliation ..........................A-39 


\subsection{SAFETY MANAGEMENT SYSTEM MECHANISMS}

\subsection{Introduction}

This appendix to the Superblock ISMS Description has been prepared in a format per DOE/OAK in Ronna Promani's letter of August 18, 1998, to Dr. Dennis K. Fisher, LLNL's Associate Deputy Director for Operations.

This document describes the mechanisms in place to implement an Integrated Safety Management System (ISMS) in the Plutonium Facility, Building 332 (B332), within LLNL's Superblock. A matrix portraying a crosswalk of the programs, systems, and procedures in place to meet ISMS functions and principles in B332 is provided in Section 7.0, Integration. B332 operates under the authority of an Authorization Agreement (AA) between LLNL's Associate Director for Defense \& Nuclear Technologies (AD/DNT) and the Manager of the Oakland Operations Office, revised and signed January 28, 1999.

\subsection{Roles and Responsibilities}

Line Management Responsibility for Safety (Guiding Principle 1)

Clear Roles and Responsibilities (Guiding Principle 2)

Competence Commensurate with Responsibility (Guiding Principle 3)

\subsubsection{Line Management Responsibility for Safety}

B332 is managed by a Facility Manager (FM) with the support of a Facility Staff. The AD/DNT, through the Nuclear Materials Technology (NMT) Program Leader and his deputies for Programs and Facility Operations, has delegated to the B332 FM the authority for, and holds the FM responsible for, operating the Facility and ensuring that the Facility meets Laboratory Environmental, Safety and Health (ES\&H) requirements.

LLNL ES\&H responsibilities are clearly delineated in the Environmental, Safety and Health Manual (ES\&HM). Volume I, Part 2 specifically discusses the responsibilities of the Facility Manager with respect to safety controls and hazard mitigation. The specific ES\&H responsibilities for the B332 FM are detailed in Section 2 of the FSP, the Nuclear Materials Technology Program Management Plan, and in Chapter 17 of the SAR. These resportsibilities are briefly summarized as follows:

- Ensure the implementation of an ES\&H program that complies with applicable ES\&H regulations.

- Jointly approve the ES\&H Discipline Actions Plans for Building 332 with the ES\&H Team Leader. 
- Ensure that everyone working in the facility follows the safety and environmental controls and other ES\&H requirements stated in the:

- LLNL ESEH Manual.

- Nuclear Material Control and Accountability Program Manual (NMC\&APM).

- Building 332 QA Plan.

- Plutonium Facility policies and procedures.

- B332 SAR, TSR, and FSP.

- Applicable OSPs.

- Take all necessary actions to minimize the following to as low as reasonably achievable (ALARA):

- Internal and external ionizing radiation dose to personnel.

- Radioactive and toxic materials releases from normal operations to the environment.

- Consequences from accidents, incidents, and abnormal occurrences.

- Generation of hazardous, radioactive, and mixed wastes.

- Submit all Level A OSPs, including those for operations that involve more than $45 \%$ of the minimum critical mass of a given form of fissionable material (e.g., $>220 \mathrm{~g}$ of dispersible plutonium or $>2600 \mathrm{~g}$ of a solid piece of plutonium) to the Associate Director (AD) for DNT or designated alternate and to other ADs for concurrence and/or approval, as appropriate.

- Notify and report to the NMT Program Leader and Laboratory management incidents and occurrences that have ES\&H significance, investigate such incidents and occurrences, and assign corrective actions.

- Act as initial Incident Commander during abnormal conditions and minor emergencies.

- Assist Materials Management Section (MMS) in resolving materials control and accountability (MC\&A) related concerns and occurrences.

- Ensure that a facility-specific training program is developed and implemented for personnel with work assignments in the Facility.

- Ensure that nonconformances with transuranic (TRU) waste and low-level waste (LLW) acceptance and certification requirements are corrected.

- Ensure that an overall facility plan for effective decontamination and decommissioning (D\&D) of obsolete workstations and equipment is in place.

- Ensure that facility-related Safeguards and Security (S\&S) issues are addressed with appropriate regard for ES\&H.

- In conjunction with applicable programs or personnel, ensure that gloveboxes in which program work has been terminated are left in a safe and secure condition.

- Ensure that the Plutonium Facility-Building 332 Safety Analysis Report (SAR) is reviewed annually to verify that the safety analysis is still applicable for current operations and activities, and submit revisions of the SAR to Department of Energy (DOE). 
- Concur with the ESEH Team Action Plan for Building 332.

- Approve Unresolved Safety Question (USQ) Determinations.

- Charter the Facility Engineering Design Review (FEDR) process.

- Chair the Daily Activity Scheduling Meeting.

- Establish systems to ensure continuous feedback and improvement based on lessons learned.

- Require that personnel conform to the facility's TIM through constant assessment by the NMTP Training Manager that the required training is current.

\subsubsection{Clear Roles and Responsibilities}

The program, payroll, Facility, and support (service) responsibilities are characterized as a "management chain" in the LLNL ISMS description, Section 6.2.3. Responsibilities for the B332 organization are discussed in greater detail in Chapter 17 of the Plutonium Facility-Building 332 Safety Analysis Report (SAR) and in Section 3 of the Plutonium Facility-Building 332 Facility Safety Plan (FSP). Figures B-1 and B-2 in Appendix B of the FSP provide LLNL and B332 organization charts for Facility, programmatic and support organizations. B332 is managed by a Facility Manager (IM) with the support of a Facility Staff. The AD/DNT, through the Nuclear Materials Technology (NMT) Program Leader, has assigned to the FM the authority for, and holds him responsible for, operating the Facility and ensuring that the Facility meets Laboratory environmental, safety and health (ES\&H) requirements. The ES\&HM establishes ES\&H requirements, and the FSP establishes the basic ES\&H controls for the Facility. The FSP is the primary document that addresses implementation of the requirements. All personnel doing work in the Facility, including residents, support from other LLNL organizations, and subcontractors, must pass an examination on their safety responsibilities prior to unescorted access into the Radioactive Materials Area (RMA). Fissile Material Handlers (FMHs) also must pass a comprehensive examination on the Facility's safety basis documents, including the FSP, prior to access into the RMA. Cleared personnel not approved for unescorted access, such as support personnel and subcontractors, must view a safety video prior to entering the RMA and must be accompanied by a safety escort.

\subsubsection{Competence Commensurate with Responsibilities}

Programs to establish and maintain competency for B332 personnel are prescribed in the LLNL Plutonium Facility Personnel Selection, Qualification, and Training Plan (hereafter referred to as the B332 Training Plan) and are complementary to the requirements of the B332 SAR, particularly in Subsection 12.4. Facility-specific training, qualification, and certification of B332 personnel are as specified in the B332 Training Implementation Matrix (TIM) approved by DOE and as required by the B332 Technical Safety Requirements (TSR) and by the B332 Training Plan. Course requirements for RMA workers can be found on the Superblock Server (available to all B332 residents and many regular users), and are updated as requirements change. Training requirements are established by payroll, program, and facility organizations. LLNL's Livermore Training Requirements and Information Network (LTRAIN) program is a software tool that aids payroll supervisors in establishing required employee training and tracks the training required for and accomplished by employees. Payroll organizations establish general requirements, such as basic competency and general safety courses and are responsible for their 
employees completing institutional training requirements. The Facility establishes facilityspecific training requirements, such as safely handling fissile materials, on-the-job training, and training on Facility-specific safety documents such as its SAR, FSP, etc. Programs using matrixed employees may specify to the payroll organization additional training required to conduct their programmatic mission. The Facility assists users in developing and implementing Operational Safety Plans (OSP) training. Programmatic users of the Facility are responsible for ensuring that training for personnel working under their OSPs is up to date. The FM has assigned to the Facility Operations and Maintenance Manager (FOMM) the responsibility for assuring that training for the Facility Operations personnel is up to date.

Worker participation in safety planning and implementation is ensured through a number of mechanisms, including OSP preparation, reviews, and training, quarterly safety briefings, prejob briefings, etc., which invite input from workers at all levels, starting with the initiation of the activity's scope of work and identification of hazards. Primary tasks on behalf of programs are accomplished within the Facility by teams of workers, under the supervision of a Senior Certified FMH, whose title signifies the completion of extensive handling and safety training to meet the B332 TIM in compliance with DOE Order 5480.20A. For programmatic activities, they may be the OSP Responsible Individuals (RIs) and/or RMA Supervisors appointed by the FM. Each worker in the RMA is classified in one of the following classifications, from highest to lowest: (1) Senior Certified FMH; (2) Certified FMH; (3) FMH Associate; (4) Radiation Zone Worker II; or (5) Radiation Zone Worker I. Senior Certified FMIIs are the only personnel allowed the full range of handling of special nuclear material (SNM), for example, within safety and security controls for specific workstations. Their teams generally are a close-working group of three to six people, all of whom will have been trained and qualified at least to the Radiation Zone Worker I level, but generally to the FMH level. Senior Certified FMHs are involved from the beginning of the design of new processes or operations to ensure that procedures can be completed as written and are as understandable and worker-friendly as possible while meeting ES\&H requirements. Senior Certified and Certified FMHs are involved in the preparation of work control documents and training for the OSPs. Per OP-B332-002, "Daily Activity Scheduling," they are responsible for providing Daily Activity Scheduling (DAS) input and attending the meetings to coordinate their activities with those of others in the RMA. A Senior Certified or Certified FMH is decertified by the FM if training lapses, proficiency is not maintained, or for a safety violation deemed by management to be significant, that is, a willful violation seriously threatening to health or the environment. See also Sections 6.7.1 and 6.7.2 for programmatic, facility operation, and subcontractor inputs into procedures and work planning.

Also involved in the DAS process and subject to all work control requirements are the Facility Operations personnel. These persons are responsible for maintaining the Facility safety-class and safety-significant systems, structures, and components (SSCs), which are required to be functional for the programmatic operations.

With regard to reporting potentially unsafe or noncompliant situations, all Facility workers are directed, under QIP3, "Corrective Action Record (CAR)," as follows:

"Anyone detecting a situation, procedure, or issue that deviates from requirements or specifications, and believes the situation jeopardizes health or safety or is not in compliance with applicable requirements, shall complete the 'Description of Problem' section of the CAR form...." 
In addition, under the ES\&HM, Volume I, Part 2, "all employees are responsible for...requesting that work be stopped if they observe others performing an operation (or are in a situation) that is perceived to be imminently dangerous to health, safety, or the environment...."

\subsection{Work Planning and Prioritization}

Define the Work Activity (Core Function 1)

Balanced Priorities (Guiding Principle 4)

\subsubsection{Translate Mission into Work}

As stated in the Authorization Agreement (AA), B332 currently supports the DOE mission in the following activities:

A. DOE Defense Programs Stockpile Stewardship and Management Plan

- Stockpile Stewardship

-Dual revalidation

-Sample preparation for subcritical experiments

-Flight-test preparation

- Enhanced surveillance

- Pit Rebuild Program

- RFP Pit Dismantlement

-Bisection of pits

-Conversion of pit materials into oxide

B. Plutonium Stabilization

C. Supporting Services

- Metallography

- Plutonium Recovery

- Analytical Chemistry

- Welding

- Fissile Material Machining

- Material Management

D. Fissile Material Disposition Program

- Immobilization of plutonium in ceramic

- Pit disassembly and conversion

E. Trilateral Activities 


\section{F. Site Repository of Special Nuclear Materials \\ G. Other DOE-related Activities}

The AA between the AD/DNT and DOE/OAK establishes and defines authorized operations. Specific operations encompassed by the SAR are further described by the FSP and the OSPs. The FSP and the OSPs define the controls applicable for operations based upon the hazards analyses.

The Facility recognizes two separate and distinct systems for management of work in B332. One system addresses the Facility and the confinement controls maintained in accordance with the TSR. The second concerns the (programmatic) mission work controlled by the FSP and OSPs. The two systems are complementary and together comprise all the requirements to maintain the safety controls to mitigate hazards within the bounds of the SAR. The Unreviewed Safety Question (USQ) process is designed to maintain the integrity of the systems and processes within that safety envelope. For programmatic activities, the FM has the responsibility for establishing the controls, and the programmatic RI has the responsibility for ensuring, on a day-to-day basis, that the personnel performing the work are doing so within the controls. The FM has responsibility for both establishment and compliance for Facility operations activities.

As described in the ES\&HM, Volume I, Part 2, and LLNL's Maintenance Implementation Plan (MIP) of March 1995, B332 implements the MIP through its Plutonium Facility-Building 332 Maintenance and Operations Manual (MOM) and executes a maintenance planning cycle for all Facility equipment. This includes equipment that directly supports tenant/programmatic work. The five identifiable phases in the planning cycle are conception, design/plan, production/procurement, operation, and termination/disposal. For Facility Operations equipment, these processes are inherent within the building, but programmatic equipment may involve extensive interface with other program equipment and personnel. See Section 8.0, Budget and Planning Process, for information on how the execution of the MOM relates to the budget process for maintenance and upgrades of Facility equipment.

Activity work scopes are defined by programmatic managers and sponsors. Programmatic representatives first contact the FM or a designee to obtain Facility requirements for work controls per the Plutonium Facility-Building 332 Work Control/Design Change Control Process Manual (Work Control Manual or WCM). The Facility User's Operations Manager is the initial primary source of assistance in coordinating new activities in accordance with the Work Control Process (see Section 6.6, below). The process for preparation of scope statements and the hazards analyses that follows is described in the WCM. Building 332-specific USQ requirements are defined in ACP-B332-011.

\subsubsection{Set Expectations}

The LLNL Director, in the ES\&HM, Volume I, Part 2, and in the LLNL ISM System Description, issued guidance for the implementation of sound safety, environmental, and health practices. Further, the ES\&HM, Volume I, Part 2, assigns the responsibility to each AD to make ES\&H a part of each employee's annual performance appraisal. 
Methods for establishing expectations for building safety systems and equipment satisfactorily complying with safety standards are contained in "General Building Policies and Controls," Section 4 of the FSP. This section discusses Limiting Conditions of Operations (LCOs), Surveillance Requirement Procedures (SRPs), Facility Operating Procedures (FOPs), and Administrative Control Procedures (ACPs). Examples of established expectations can be found throughout the SRP Task Codes wherein personnel performing the surveillances are instructed that if a particular reading is outside a specific range, they are to stop and notify Facility Operations personnel at once. In addition, SRP-B332-000 (Control and Execution of B332 Surveillance Requirements) stipulates that all SRPs and accompanying task codes are to be rigorously followed in accordance with specific policies contained in paragraph 5.0 therein.

The Facility's expectations of support personnel from matrix organizations such as Plant Engineering and Hazards Control are provided in Memoranda of Understanding (MOU), available for ready reference by all B332 residents on the Superblock server. MOU criteria include the matrix organization's responsibilities for providing qualified personnel, and references to the TIM requirements, the FSP, and the Safety Program for Plutonium Workers. The FM has MOUs with the following LLNL support organizations:

- Emergency Management Division.

- Material Management Section.

- Safeguards and Security Department.

- Plant Engineering Department.

- Environmental Protection Department.

- Hazardous Waste Management.

- Hazards Control Department.

\subsubsection{Provide for Integration}

B332 integrates ES\&H management processes into all work planning activities by using the process described in the WCM. See Figure 1 on the next page.

The first step is for the RI to describe the proposed activity. The second step initiates the integration process wherein the RI planning an activity critically evaluates ES\&H issues in consultation with Senior Certified FMHs and others involved in the task planning, as appropriate, and contacts the Facility User Operations Manager. In furthering this process, the RI may use the services of the assigned ES\&H specialists available in LLNL's ES\&II Team 1 and the B332 Facility Safety Office in completing the Facility's hazards analyses patterned after the ES\&H Integration Worksheet in the ES\&HM and required by the WCM. These specialists are in the areas of health physics, industrial safety, industrial hygiene, fire safety, and environmental analysis. Criticality safety support is provided by the LLNL Hazards Control Department. Hazards analyses are required for programmatic and facility activities and for equipment installation and operation. The resulting ES\&H evaluation is submitted to the FM for approval. The FM may concur with the activity if it conforms to existing Facility work control documents (e.g., FSP, OSPs, Work Permits, Facility Operating Procedures) and falls within the existing safety authorization basis. 


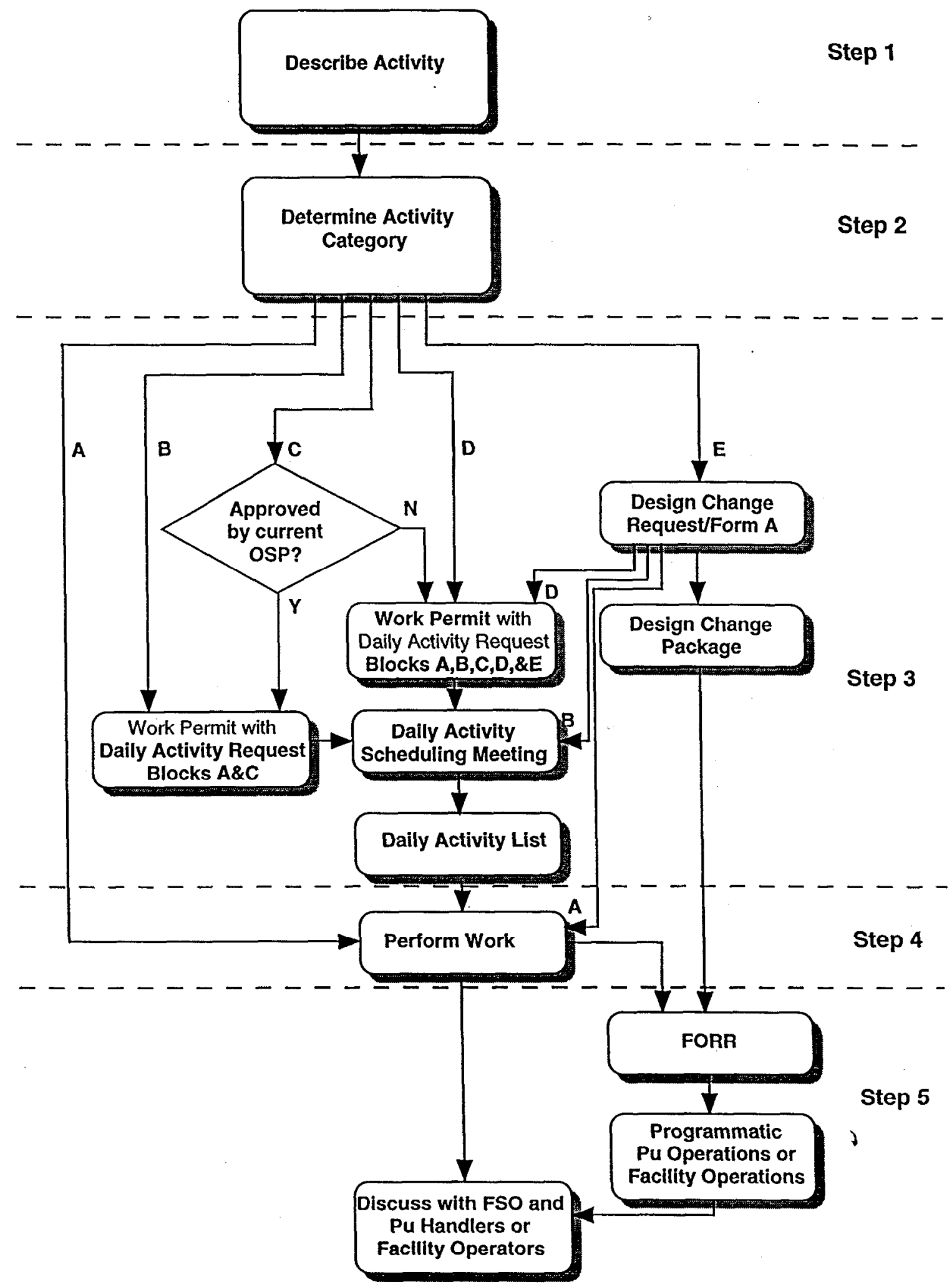

Figure 1. Overview of work control/design change control process. 
After the activity category has been determined, one of five paths will be followed, depending on the hazards, mitigations, and controls. As described in the WCM (see Section 6.4.1, herein), the FM has the authority to direct the preparation of additional safety analyses and changes to the FSP, OSPs, Work Permits, operating procedures, or other documentation, including USQ documentation. Section 7.2.1.5 of the WCM provides for a review by Facility Staff specifically for Category E work. By consensus, they recommend to the FM whether the complexity of the work justifies additional review by the Facility Engineering Design Review Committee (FEDRC). If in agreement, or by his own decision, the FM may require the activity requestor to present the activity to the FEDRC for further analysis per Subsection 3.7.3 of the FSP and the B332 Quality Assurance Plan (see Section 6.5.3, herein). The flow of work authorization and controls using a graded approach are included with the Work Permit requirements detailed in the WCM, and reproduced schematically at Figure 1. Section 6.4 .2 below briefly describes all the Activity Categories.

\subsubsection{Prioritize Tasks and Allocate Resources}

B332 complies with the LLNL policy to perform work in a manner that protects the health and safety of employees and the public, preserves the quality of the environment, and prevents property damage. ES\&H are priority considerations in the planning and execution of all work. Methods safe to workers, the public, and property will be established for the work to be accomplished according to the needs of tenants or programs and within the budget established, or the FM will not authorize the activity to commence.

Situations where programs compete for identical resources occur infrequently. Such conflicts are resolved by the FM based on input from sponsors. Every effort is made to meet programmatic needs. The Facility's Daily Activity Schedule (DAS), formalized in OP-B332-98002 and open to attendance to all RIs and workers, is the primary forum for task prioritization, coordinating resources, and resolving interferences if and when they occur.

Funding for operations and maintenance in B332 has two primary sources: DNT programmatic funding and "user fees" from other programmatic projects. Secondarily, some institutional funding is provided for specific material management activities from the institutional General and Administrative (G\&A) funding, and some personnel may charge directly to other programmatic or support accounts. The DNT programmatic funding is determined by the AD/DNT based upon annual budget plans provided by the NMT Program Leader. The user fees are negotiated between programs and the NMT Program Leader, generally at $10 \%$ of a project's funds.

Budgeting and spending generally are directly programmatic or Facility-based. Programmatic personnel charge their time directly to programmatic accounts. They usually are not B332 residents, although technicians and machinists may be both resident and dedicated to a program. Facility personnel may also include most managers and support (c.g., hazards control or material management). Additional information on funding, responsibilities, and prioritization is provided in this document in Section 8.0 and in the LLNL ISMS description, Sections 6.3 and 9.1 .

Before each fiscal year, the FM submits a work plan to the NMT Program Leader listing prioritized improvements above the minimum estimate to maintain B332 and provide support 
and services to users. The priorities are agreed upon and approved depending on the amount of additional funding actually realized through the year. Any incremental increases required for ES\&H training, Facility operations, and building safety systems must always be included in the approved work.

\subsection{Hazards Analysis}

Analyze Hazards (Core Function 2)

\subsubsection{Identify and Analyze Hazards}

All activities conducted in B332 require a critical evaluation of the hazards to workers, the public, and the environment prior to conducting work. The determination of the analysis techniques to be used and the rigor to be applied is based on the hazards associated with performing the work. The Plutonium Facility-Building 332 Safety Analysis Report (SAR) (UCRLAR-119434) addresses the hazard analyses used for the Facility. The SAR addresses the nuclear hazards as well as the hazards associated with hazardous materials used within the Facility. The SAR and its identified processes are the hazard analysis techniques that utilize the most rigor, are the most completely documented, and evaluate the hazards and risks to the Facility workers, the public, and the environment. SAR hazards analyses are performed by Subject Matter Experts (SMEs) in concert with Facility personnel and workers acquainted with operations and activities, using "failure mode and effects analysis" in accordance with DOE STD 3009 and DOE O 5480.23.

A wide variety of hazardous operations is performed in B332. Hazards may be to workers, the public, or the environment. This variety of operations requires a flexible, or graded, approach to evaluating hazards based on the risks involved. RIs, working in concert with workers, Facility Management, and ES\&H Team 1, determine at what levels a documented evaluation shall be performed. New proposed activities and equipment installations, major changes to existing activities, equipment modifications, and maintenance and other work activities are evaluated against the authorization basis, screened, analyzed, and authorized through meeting the requirements in the WCM. This manual provides guidance and requirements for hazards identification and assessment; establishment of appropriate controls and implementation of those controls; and the methods and requirements to authorize the work to be accomplished. Controls identified by this process that are not already covered in the FSP are delineated in Work Permits (for Facility Operations work), or OSPs or Work Permits (for programmatic and facility maintenance work).

\subsubsection{Categorize Hazards}

J

Hazards categorization is a major element of the WCM process. The WCM identifies five categories (A-E) of increasingly complex and/or potentially hazardous work activities with commensurate hazard analysis and associated controls.

The definitions of the Activity Categories A through $\mathrm{E}$ are as follows: 
- Activity Category A

Category $\mathrm{A}$ activities are routine, low-hazard activities and have a low probability for impacting facility operations. These activities have been thoroughly studied and have sufficient guidance documentation and controls in place to assure their safety.

- Activity Category B

Category B activities include preventive maintenance and transfer, shipping, and receiving of nuclear materials. The hazards associated with these activities are addressed by the controls identified in the B332 Facility Safety Procedure (FSP), including equipment or system operating procedures and Surveillance Requirement Procedures (SRPs).

- Activity Category C

Category $\mathrm{C}$ activities include handling any quantity of ${ }^{238} \mathrm{Pu}$, operations of analytical $\mathrm{x}$ ray machines, and laser operations with Class 4 lasers. These activities are controlled by Operational Safety Procedures (OSPs).

- Activity Category D

Category D activities include performing corrective maintenance of BSSs and other building systems and programmatic equipment within the current design configuration, opening and repackaging previously sealed waste containers, and using Class IV standards and/or sealed radioactive sources. Category $D$ activitics are reviewed by ES\&H Team 1 to identify potential hazards and mitigating controls.

- Activity Category E

Category E activities represent changes to facility and programmatic SSCs, including new construction or modification to Facility and/or programmatic equipment; installation, modification, or removal of a workstation; introduction of a new process; or any activity designated by the Facility Manager.

Category $\mathrm{E}$ activities require a hazards analysis as part of the design change package (DCP). Once a Category E activity has been approved, the installation of the new or modified SSC becomes a Category D activity.

Documentation requirements vary by category, as shown in the following matrix:

\begin{tabular}{|c|c|c|c|c|}
\cline { 2 - 5 } \multicolumn{1}{c|}{} & \multicolumn{4}{|c|}{ Documentation Requirements } \\
\hline $\begin{array}{c}\text { Activity } \\
\text { Category }\end{array}$ & $\begin{array}{c}\text { Daily Activity } \\
\text { Request Form }\end{array}$ & $\begin{array}{c}\text { Operational Safety } \\
\text { Procedure } \\
\text { (OSP) }\end{array}$ & $\begin{array}{c}\text { Work Permit } \\
\text { and Work } \\
\text { Package }\end{array}$ & $\begin{array}{c}\text { Work Request/ } \\
\text { Form A } \\
\text { and Design } \\
\text { Change Pkg. }\end{array}$ \\
\hline A & - & - & - & - \\
\hline B & $X$ & - & - & - \\
\hline C & $X$ & $X$ & - & - \\
\hline D & - & - & - & X \\
\hline E & - & - & - & - \\
\hline
\end{tabular}




\title{
6.5 Hazard Mitigation and Control
}

\author{
Develop/Implement Hazard Controls (Core Function 3) \\ Identification of Safety Standards and Requirements (Guiding Principle 5) \\ Hazard Controls Tailored to Work Being Performed (Guiding Principle 6)
}

\subsubsection{Identify Standards and Requirements}

B332 operations conform to all applicable laws, statutes, Federal rules, and DOE directives. Parallel with the LLNL ISMS implementation plans and Work Smart Standards (WSS), B332 uses Laboratory manuals of practice, the ES\&H Manuals, and Directorate-specific documentation to address its special operations, activities, and hazards. The standards and requirements currently in the SAR, and eventually to be reconciled with the site-wide WSS, incorporate appropriate national consensus standards and DOE Guides and technical standards, and provide for DOE/OAK review and concurrence. During each stage of work review, RIs are required to provide information on procedures, equipment, and facilities to protect the public, employees, and property. As stated in the LLNL ISMS description (Section 3):

The reconciliation of the initial Superblock ISMS Description with the Institutional ISMS Description required a number of aspects to be addressed. These have been and continue to be done consistent with the completion of the impacting actions and documentation. The Superblock Description was completed and submitted to DOE in October 1998. The initial version of this Institutional ISMS Description was completed on December 29, 1998, and was different in a number of important ways. It contained new definitions and operational methodologies that have resulted from the Laboratorywide efforts to align with the DOE Integrated Safety Management Policy and the accompanying Guidance and other related documentation.... The particular hazards involved require a high level of formality and specificity that are not required for most of the other operations at LLNL. This Institutional Description encompasses and provides for the Superblock activities through the establishment of the Institutional requirements and major implementation considerations using increasing formality, analysis, and documentation commensurate with the hazards....The Superblock Description is appropriately subordinate to this Institutional Description. Upon full Description reconciliation, incorporation of the WSS set, and completion of the Verification process, further documentation hierarchy changes may be constructive and useful and incorporated accordingly.

Attachment A to this Appendix is a current reconciliation between the Authorization Basis standards and orders and the WSS. It identifies those areas where changes in the Authorization Basis will be required.

\subsubsection{Identify Controls to Prevent/Mitigate Hazards}

The SAR identifies hazards and accident scenarios, the potential occurrences of which are controlled at the highest level by practices described in the general building policies established in the TSR. In support of these controls, the Facility has a formally established set of TSRs and operating practices. The B332 FSP specifies operating practices, access controls and 
requirements, and general building rules. SAR Chapters 6 through 17 describe the various B332 safety programs. The matrix below gives a list of the Facility's programs and the RI for each.

\begin{tabular}{|c|c|c|}
\hline SAR Chapter & Safety Program & Facility Responsibility \\
\hline 6 & Prevention of Inadvertent Criticality & Criticality Safety Group Leader \\
\hline 7 & Radiation Protection & ES\&H Team 1, Health Physicist \\
\hline 8 & Hazardous Material Protection & ES\&H Team 1, Industrial Hygienist \\
\hline 9 & $\begin{array}{l}\text { Radioactive and Hazardous Waste } \\
\text { Management }\end{array}$ & $\begin{array}{l}\text { Waste Manager (for HW and } \\
\text { unaccountable SNM quantities) } \\
\text { Materials Management (for } \\
\text { accountable SNM quantities) }\end{array}$ \\
\hline 10 & $\begin{array}{l}\text { Initial Testing, In-Service Surveillance, and } \\
\text { Maintenance }\end{array}$ & $\begin{array}{l}\text { Facility Operations \& Maintenance } \\
\text { Manager }\end{array}$ \\
\hline 11 & Operational Safety & $\begin{array}{l}\text { Facility Operations \& Maintenance } \\
\text { Manager }\end{array}$ \\
\hline 12 & Procedures and Training & $\begin{array}{l}\text { Procedures - Safety Manager } \\
\text { Training -- Training Officer }\end{array}$ \\
\hline 13 & Human Factors & Safety Manager \\
\hline 14 & Quality Assurance & Quality Assurance Engineer \\
\hline 15 & Emergency Preparedness Program & Safety Officer \\
\hline 16 & $\begin{array}{l}\text { Provisions for Decontaminating and } \\
\text { Decommissioning }\end{array}$ & Facility User Operations Manager \\
\hline 17 & $\begin{array}{l}\text { Management, Organization, and Institutional } \\
\text { Safety Provisions }\end{array}$ & Facility Manager \\
\hline
\end{tabular}

Activities in B332 are assessed routinely during the planning phases of an activity as prescribed in the WCM. As the planning of the activity progresses, the following steps are prescribed:

(1) Identify the safety and health hazards and the environmental concerns of the activity (conducted by all participants, including workers).

(2) Evaluate whether the activity falls within the Facility's authorization basis per the Facility's Unreviewed Safety Questions (USQ) process, which is required per the WCM and defined in ACP-B332-011.

(3) Identify the controls necessary to conduct the operations safely and in compliance with accepted standards and regulations.

(4) Identify and prepare documents necessary to conduct the operation and implement the controls. These documents may include OSPs, operating procedures, permits, or other documentation such as decontamination and disposition plans, and Quality Assurance plans.

A comprehensive system to tailor the controls as an enhancement to the ES\&HM requirements is in development, called the "CHOOSE" (Controls/Hazards Operations-Oriented Safety Envelope) database. It describes a technique to use a graded approach for achieving an 
acceptable level of risk. The graded approach identifies the level of effort that would be cost effective or commensurate with the risk involved. To further protect the public, employees, and environment, B332 has a formalized Emergency Preparedness Program, described in Chapter 15 of the SAR and proceduralized in Appendix G of the FSP.

\subsubsection{Establish and Implement Safety Controls}

A hierarchy of safety controls has been established in B332. As discussed above, the SAR has identified hazards and established the safety envelope for the building. These hazards and accident scenarios are mitigated at the highest level through the TSR and are enforced through monitoring, surveillance, and operational controls as defined in the ACPs, SRPs, LCOs, and FOPs. Controlled copies of these documents are provided to Facility staff and certain others as the documents are updated; other interested personnel may obtain uncontrolled copies directly from the Superblock server.

The Facility uses its FSP, OSPs, and Work Permits to implement controls for programmatic operations. The FSP describes the safety and environmental controls as Facility-standard practices and for long-term activities. The FSP is required to be reviewed, updated, and reissued every three years. During the three-year interval, FSP changes may be approved as needed. OSPs describe controls for individual, limited-term activities and are reviewed annually. Changes to OSPs required during the annual cycle are approved and issued as OSP Supplements. Work Permits also describe controls for individual, limited-term activities and are generally valid for seven days, but can be extended. Controls include specific safety requirements (e.g., lockout and tag requirements described in the ES\&HM, Volume II, Part 13).

In addition to LLNL work permits that are routinely required for welding, burning, or other hazardous operations (see the ES\&HM, Volume II, Part 10), B332 Work Permits as described in the WCM are required for specific Facility and programmatic maintenance and operations to ensure that potential hazards are identified and necessary precautions are in place before beginning work in the Facility.

To provide procedures for guaranteeing high standards of quality, in accordance with LLNL's Quality Management Program Plan M-078, the Facility has prepared a Quality Assurance Plan (QAP) (M-078-20) to implement the requirements of 10 CFR 830.120. The QAP ensures:

- Facility Management provides the planning, organization, direction, control, and support required to achieve the program's missions.

- Facility user and support organizations achieve quality that is documented.

- Overall performance of the Facility is reviewed and evaluated using an assessment process.

Quality guides and standards are contained in Quality Assurance Implementing Procedures (QIPs) and Quality Operating Procedures (QOPs).

B332 work and design change control is described in the WCM in accordance with the process described in Section 6.3.3, above. The Facility's document change control is described in the QIP 6 document and QA Record Control. 


\title{
6.6 Work Authorization and Execution
}

\author{
Perform Work (Core Function 4)
}

Operations Authorization (Guiding Principle 7)

\subsubsection{Confirm Readiness}

The AD/DNT commissioned a B332 Activity Resumption Assessment, conducted with $\mathrm{DOE} / \mathrm{OAK}$ participation, in which both the AD/DNT and DOE/OAK Site Manager concluded in April 1999 that B332 could be operated within the controls specified in the approved B332 Authorization Agreement.

B332 complies with the requirements of the ES\&HM, Volume I, Part 2, for conducting prestart and readiness reviews, and Volume V, Part 5, for startup and restart of facility and programmatic activities. Prior to commencing an activity, the FM conducts a series of operational and safety reviews. In addition to OSP reviews, these include Facility Engineering Design Reviews (FEDRs) and Facility Operational Readiness Reviews (FORRs). The DOE may also require additional reviews of operations and safety in accordance with the AA and DOE Order 5480.31. These reviews of the operations ensure that:

(1) Hardware and tools are available, the facility is operable, and the equipment is tested.

(2) The required safety systems are correctly installed and tested and the appropriate personnel are trained in the use of these systems.

(3) The activities and/or experiments are ready, procedures are complete, maintenance of safety systems is scheduled, ES\&H documentation is complete, and permits are issued as required.

(4) Personnel know their responsibilities and are trained or certified as required for the operations.

\subsubsection{Operations Authorization}

B332 operations are in accordance with the AA. Activities will be reviewed, approved, and authorized per the WCM. The final check for compliance will be in the DAS. Each DAS (see also Section 6.3, above) is approved by the Facility Manager to indicate authorized work and activities.

\subsubsection{Perform Work Safely}

Safety requirements are incorporated into the FSP, OSPs, WCM, ACPs, SRPs, FOPs, operating procedures, Work Permits, and other work control documents as required. B332 has implemented the requirements of the ES\&HM, Volume I, Part 2, "ES\&H Management Requirements." Facility maintenance is conducted in accordance with an approved LLNL MIP and the Facility's MOM. These provide requirements for the use of procedures, detailed checklists, outlines of tasks, and skill of the craft that requires no written procedure. 
Work Permits ensure that personal protective equipment and contamination and operational safety controls are adequate for the proposed work. Facility workers are competent and properly trained people with a clear understanding of management expectations. As stated in Section 6.2, workers understand under LLNL and Facility procedures that they have the right and responsibility to stop potentially unsafe work and report unsafe situations.

\subsubsection{Performance Measures}

Consistent with Section 6.7.1.3 of the LLNL ISMS Description and Section 6.6.4 of the Superblock ISMS Description, Building 332 will contribute to the institutional performance objectives, criteria, and measures (POCMs). A system wherein targets can be established and performance can be objectively measured and tracked is under development. The first six areas below have been identified as relating to the Contract 48 Appendix F performance measures. The remaining areas also are being considered.

- Implementing the five core functions of Integrated Safety Management based on this ISMS Description (App. F, Part II-2, Criteria 1.4).

- Maintaining zero toxic material and physical agent exposure (App. F, Part I-2, Criteria 1.4.d).

- Maintaining zero incidence of environmental regulatory violations and releases (App.F, Part II-2, Criteria 1.4.h).

- Setting and maintaining ALARA goals for the facility workers (App. F, Part II-2, Criteria 1.4.a).

- Reducing standard occupational safety and health injury rates to a level that is at or below the mean rate for the DOE complex. We propose to accomplish this by raising worker consciousness through improved communication of accident- and injuryprevention strategies (App. F, Part II-2, Criteria 1.4.e).

- Reducing the generation of transuranic, low-level, mixed, and hazardous wastes to meet DOE's pollution-prevention goals for the year 2000 (App. F, Part II-2, Criteria 1.4.g).

- Reducing safety-related occurrences, also through raising worker consciousness, similarly to the occupational injury and illness item above.

The annual institutional performance assessment by the Laboratory, University of California, and DOE/OAK will reflect the contributions of Building 332 to the Laboratory's overall performance in accordance with Contract 48.

\subsection{Performance Monitoring and Improvement}

Feedback and Improvement (Core Function 5)

\subsubsection{Collect Feedback Information}

LLNL has a documented hierarchy of assessments that provide data and information for the feedback process. As for all facilities within DNT and the Superblock, B332 uses the Deficiency Tracking System (DefTrack) to track the status of ES\&H deficiencies. These deficiencies may 
result from assessments conducted in accordance with the DNT Self-Assessment Plan (DNTSA.4), occurrence report corrective actions, incident analysis judgments-of-need, potential PriceAnderson Amendments Act (PAAA) non-compliance issues, and all external assessments conducted by organizations outside of DNT. As discussed in the main body of the Description, the Facility uses the Master Action Database (MAD) to track and evaluate the success and consistency of the Facility's implementation of applicable rules and regulations regarding safety, health, environmental protection, and quality management as defined in the SAR/TSR and implemented through the FSP. Each action item in the MAD is assigned a code based on the LLNL Compliance Code system and an ISMS code based on the Guiding Principles and Core Functions. These codes allow sorting, which will help Facility Management identify possibly undesirable trends in shortcomings. Other sorting data allow additional trends on age of the item, responsible persons, priorities, etc., which are reported monthly to the FM and staff. The Facility also evaluates its implementation of Conduct of Operations through internal and external inspections. The MAD database includes concerns, deliverables, and other issues not required to be entered into DefTrack.

In addition to facility management discussions of work conditions and practices gleaned from various formal and informal inspections and walk-arounds, worker feedback of any deficiencies is accomplished through the Facility's Corrective Action Request (CAR) system, per QIP3. These items are assigned to an individual who is responsible for closeout, and are monitored and tracked to closure in the Facility's database.

\subsubsection{Identify Improvement Opportunities and Make Changes to Improve}

The NMTP Feedback and Improvement Program (FIP) is instrumental in identifying deficiencies and providing lessons learned. These lessons are provided to the Facility Training Manager to disseminate as appropriate. The program is reviewed every two years to ensure that the assessments defined in it are tailored to current conditions. As indicated above, a trending capability, based on assigning LLNL Compliance Codes to each action item, provides for sorting the data to identify problem areas, allowing a concentration of resources for improvement and later input as lessons learned. Lessons learned from the database, the Occurrence Reporting program, and as distributed by other sites are discussed in Quarterly Safety Briefings (QSB; see FSP, Subsection 7.2.2) or provided to the Facility Training Manager for enhancements to Facility personnel training. An example regards a finger poke incident (OR 1997-0006) that resulted in QSB training as well as revisions to applicable lesson plans and training manuals. Root cause analyses are performed on reportable occurrences, forming the bases for corrective actions. Corrective actions are tracked to closurc per the FIP. NMTP policy requires lesser concerns and commitments to be tracked in the MAD, which includes sorting capabilities to assist in identifying areas of concern on a macro basis (such as compliance effectiveness and ISMS implementation) as well as the micro basis typical of a database. Employee recommendations for repairs and maintenance, primarily through the CAR process, are evaluated by Facility Management and become formalized action items if appropriate. Prejob briefings and walkthroughs, surveillance training, and repair and maintenance work planning sessions are opportunities for operations, programmatic, plant engineering, and subcontractor personnel to provide feedback, in the form of critiques, comments and suggestions for improvement, to work scopes and planned activities.

Improvement tools at the Facility level begin with the self-assessments performed per the FIP and the CAR system, which require personnel to report shortcomings or concerns per QIP 3. 
The improvements are ensured by the monitoring and tracking-to-closure of all findings, concerns, corrective actions, etc., per the FIP.

A Facility Walk-Around Program was instituted in late 1998 to ensure greater involvement by Facility Management in identifying and correcting potential areas of concern. The Program requires monthly interviews or observations of personnel and activities at all levels by Facility staff using prescribed guidance cards covering a broad range of subjects. Added dividends include the improvement of operational oversight and an increase in management's visibility in the RMA. Initially, Facility staff participating are the FM and a pilot group of top-level managers who report directly to the FM. Once they are trained and have had sufficient practice, remaining supervisory personnel will begin the walk-arounds. A longer-range plan is to increase the scope of the program by adding personnel from programmatic and support organizations to the B332 list of trained observers. The possibility of eventually including all Facility personnel on the list also is being evaluated.

\subsubsection{Oversight and Enforcement}

Section 3 of the FSP defines the responsibility and authority of Facility Management with regard to oversight and enforcement. In general terms, for programmatic work, Facility Management provides oversight, and program line managers have enforcement responsibility. The Facility Manager has the responsibility for assessing the adequacy of operations, equipment, and procedures, while the line manager has the responsibility for making corrections to the FM's satisfaction. For the Facility operating systems, the Facility Manager has the responsibility for both oversight and enforcement of adequate operations, equipment, and procedures. Additional oversight is provided at the next higher level by the NMT Program Leader, and by DOE/OAK through the continuous presence in the Facility of resident Facility Representatives. 


\subsection{INTEGRATION}

The integration of the functions and principles of ISMS in B332 are summarized in a matrix shown in Tables 1 through 5 . The documents listed establish and implement the Facility standards pertaining to the Core Functions and Guiding Principles for SSC operations and programmatic activities.

The following abbreviations are used in Tables 1 through 5:
AA - Authorization Agreement
DAP - Hazards Control Team 1 Discipline Action Plan
DAS - Daily Activity Schedule
DNT Policy - ES\&H Policy for the DNT Directorate, AD letter dated 2/2/96
ES\&HM - LLNL Environmental, Safety and Health Manual
FEDRC - Facility Engineering Design Review Committee
FIP - NMTP Feedback and Improvement Program
FOPs - Facility Operations Procedures
FSP - Facility Safety Plan
N/A - Not Applicable
OP - Operating Procedure
OSP - Operational Safety Plan
QAP - B332 Quality Assurance Plan
SAP - DNT Self-Assessment Plan (DNT-SA.4)
SAR - Safety Analysis Report
SER - Safety Evaluation Report
TAC - Training Advisory Committee
TIM - Training Implementation Matrix
TSR - Technical Safety Requirement
WCM - Work Control Manual (Work Control/Design Change Control Process Manual)
WP - Work Permit

Table 1. Define Scope of Work (Core Function 1) Crosswalk.

\begin{tabular}{|c|c|c|c|c|c|c|}
\hline $\begin{array}{c}\text { Line } \\
\text { Management } \\
\text { Responsibility } \\
\text { for Safety }\end{array}$ & $\begin{array}{c}\text { Clear Roles } \\
\text { and } \\
\text { Responsibilities }\end{array}$ & $\begin{array}{l}\text { Competence } \\
\text { Commensurate } \\
\text { with } \\
\text { Responsibilities }\end{array}$ & $\begin{array}{l}\text { Balanced } \\
\text { Priorities }\end{array}$ & $\begin{array}{l}\text { Identification } \\
\text { of Safety } \\
\text { Standards } \\
\text { and } \\
\text { Requirements }\end{array}$ & $\begin{array}{l}\text { Hazard } \\
\text { Controls } \\
\text { Tailored } \\
\text { to Work } \\
\text { Being } \\
\text { Performed }\end{array}$ & $\begin{array}{l}\text { Operations } \\
\text { Authorization }\end{array}$ \\
\hline $\begin{array}{l}\text { - ES\&HM } \\
\text { Vol. I, Part } 2 \\
\text { - FSP, Sect. } 3 \\
\text { - SAR, } \\
\text { Sect. } 2.3 .2 \\
\text { - DNT Policy } \\
\text { - WCM } \\
\text { - DAP }\end{array}$ & $\begin{array}{l}\text { - ES\&HM } \\
\text { Vol. I, Part } 2 \\
\text { - FSP, Sects. 2, } \\
\text { 3, and } 4 \\
\text { - SAR, } \\
\text { Sect. } 2.3 .2 \\
\text { - DNT Policy } \\
\text { - FOPs } \\
\text { - WCM } \\
\text { - DAP }\end{array}$ & $\begin{array}{l}\text { ES\&HM } \\
\text { Vol. I, Part 2, } \\
\text { and Vol. IV, } \\
\text { Part } 2 \\
\text { - TIM } \\
\text { - Training } \\
\text { Plan }\end{array}$ & $\begin{array}{l}\text { - ES\&HM } \\
\text { Vol. I, } \\
\text { Part } 2 \\
\text { - DNT } \\
\text { Policy } \\
\text { - OP-002 } \\
\text { - WCM }\end{array}$ & $\mathrm{N} / \mathrm{A}$ & $\mathrm{N} / \mathrm{A}$ & $\mathrm{N} / \mathrm{A}$ \\
\hline
\end{tabular}


Table 2. Analyze Hazards (Core Function 2) Crosswalk.

\begin{tabular}{|c|c|c|c|c|c|c|}
\hline $\begin{array}{c}\text { Line } \\
\text { Management } \\
\text { Responsibility } \\
\text { for Safety }\end{array}$ & $\begin{array}{c}\text { Clear Roles } \\
\text { and } \\
\text { Responsibilities }\end{array}$ & $\begin{array}{c}\text { Competence } \\
\text { Commensurate } \\
\text { with } \\
\text { Responsibilities }\end{array}$ & $\begin{array}{l}\text { Balanced } \\
\text { Priorities }\end{array}$ & $\begin{array}{c}\text { Identification } \\
\text { of Safety } \\
\text { Standards } \\
\text { and } \\
\text { Requirements }\end{array}$ & $\begin{array}{c}\text { Hazard } \\
\text { Controls } \\
\text { Tailored } \\
\text { to Work } \\
\text { Being } \\
\text { Performed }\end{array}$ & $\begin{array}{l}\text { Operations } \\
\text { Authorization }\end{array}$ \\
\hline $\begin{array}{l}\text { - AA } \\
\text { - ES\&HM } \\
\text { Vol. I, Part } 2 \\
\text { - FSP, Sect. } 3 \\
\text { - OSPs } \\
\text { - Facility Safety } \\
\text { Committee } \\
\text { Charter, WPs } \\
\text { - DNT Policy } \\
\text { - WCM } \\
\text { - DAP }\end{array}$ & $\begin{array}{l}\text { - AA } \\
\text { - ES\&HM } \\
\text { Vol., I, Part 2, } \\
\text { and Vol. I, } \\
\text { Part } 4 \\
\text { - FSP, Sects. } 3 \\
\text { \& } 5 \\
\text { - OSPs } \\
\text { - DNT Policy } \\
\text { - OP-002 } \\
\text { - WCM } \\
\text { - DAP }\end{array}$ & $\begin{array}{l}\text { - AA } \\
\text { - ES\&HM } \\
\text { Vol. I, Part 2, } \\
\text { and Vol. IV, } \\
\text { Part } 2 \\
\text { - TSR } \\
\text { - TIM }\end{array}$ & $\mathrm{N} / \mathrm{A}$ & $\mathrm{N} / \mathrm{A}$ & $\mathrm{N} / \mathrm{A}$ & $\mathrm{N} / \mathrm{A}$ \\
\hline
\end{tabular}

Table 3. Develop and Implement Hazard Controls (Core Function 3) Crosswalk.

\begin{tabular}{|c|c|c|c|c|c|c|}
\hline $\begin{array}{c}\text { Line } \\
\text { Management } \\
\text { Responsibility } \\
\text { for Safety }\end{array}$ & $\begin{array}{c}\text { Clear Roles } \\
\text { and } \\
\text { Responsibilities }\end{array}$ & $\begin{array}{c}\text { Competence } \\
\text { Commensurate } \\
\text { with } \\
\text { Responsibilities }\end{array}$ & $\begin{array}{l}\text { Balanced } \\
\text { Priorities }\end{array}$ & $\begin{array}{l}\text { Identification } \\
\text { of Safety } \\
\text { Standards } \\
\text { and } \\
\text { Requirements }\end{array}$ & $\begin{array}{l}\text { Hazard } \\
\text { Controls } \\
\text { Tailored } \\
\text { to Work } \\
\text { Being } \\
\text { Performed }\end{array}$ & $\begin{array}{l}\text { Operations } \\
\text { Authorization }\end{array}$ \\
\hline $\begin{array}{l}\text { - AA. } \\
\text { - ES\&HM } \\
\text { Vol. I, Part } 2 \\
\text { - FSP, Sect. } 3 \\
\text { - Facility Safety } \\
\text { Committee } \\
\text { Charter } \\
\text { - FEDRC } \\
\text { - DNT Policy } \\
\text { - WCM } \\
\text { - DAP }\end{array}$ & $\begin{array}{l}\text { - AA } \\
\text { - ES\&HM } \\
\text { Vol. I, Part 2, } \\
\text { and Vol. I, } \\
\text { Part } 4 \\
\text { - FSP, Sects. } 3 \\
\text { \&5 } \\
\text { - OSPs } \\
\text { - DNT Policy } \\
\text { - OP-002 } \\
\text { - WCM } \\
\text { - DAP }\end{array}$ & $\begin{array}{l}\text { - ES\&HM } \\
\text { Vol. I, Part 2, } \\
\text { and Vol. I, } \\
\text { Part 4, and } \\
\text { Vol. V, Part } 1 \\
\text { - TIM } \\
\text { - Training } \\
\text { Plan }\end{array}$ & $\mathrm{N} / \mathrm{A}$ & $\begin{array}{l}\text { - } \text { AA } \\
\text { - ES\&HM } \\
\text { Vol. I, } \\
\text { Part } 2 \\
\text { - SAR } \\
\text { - TSR } \\
\text { - FSP } \\
\text { - OSPs } \\
\text { - WP } \\
\text { - } \text { QAP } \\
\text { - WCM } \\
\text { - DAP }\end{array}$ & $\begin{array}{l}\text { - ES\&HM } \\
\text { Vol. I, } \\
\text { Part } 2 \\
\text { - SAR } \\
\text { - TSR } \\
\text { - FSP } \\
\text { - OSPs } \\
\text { - WP } \\
\text { - WCM } \\
\text { - DAP }\end{array}$ & $\mathrm{N} / \mathrm{A}$ \\
\hline
\end{tabular}

Table 4. Perform Work within Controls (Core Function 4) Crosswalk.

\begin{tabular}{|c|c|c|c|c|c|c|}
\hline $\begin{array}{c}\text { Line } \\
\text { Management } \\
\text { Responsibility } \\
\text { for Safety }\end{array}$ & $\begin{array}{l}\text { Clear Roles and } \\
\text { Responsibilities }\end{array}$ & $\begin{array}{c}\text { Competence } \\
\text { Commensurate } \\
\text { with } \\
\text { Responsibilities }\end{array}$ & $\begin{array}{l}\text { Balanced } \\
\text { Priorities }\end{array}$ & $\begin{array}{l}\text { Identification } \\
\text { of Safety } \\
\text { Standards } \\
\text { and } \\
\text { Requirements }\end{array}$ & $\begin{array}{c}\text { Hazard } \\
\text { Controls } \\
\text { Tailored } \\
\text { to Work } \\
\text { Being } \\
\text { Performed }\end{array}$ & $\begin{array}{l}\text { Operations } \\
\text { Authorization }\end{array}$ \\
\hline $\begin{array}{l}\text { - AA } \\
\text { - ES\&HM } \\
\text { Vol. I, Part } 2 \\
\text { - DNT Policy } \\
\text { - WCM } \\
\text { - DAP }\end{array}$ & $\begin{array}{l}\text { - AA } \\
\text { - ES\&HM } \\
\text { Vol. I, Part } 2 \\
\text { - FSP, Sect. } 3 \\
\text { - OSPs } \\
\text { - DNT Policy } \\
\text { - FOPs } \\
\text { - WCM } \\
\text { - DAP }\end{array}$ & $\begin{array}{l}\text { - ES\&HM } \\
\text { Vol. I, Part 2, } \\
\text { and Vol. IV, } \\
\text { Part } 2 \\
\text { - TIM } \\
\text { - Training } \\
\text { Plan }\end{array}$ & $\mathrm{N} / \mathrm{A}$ & $\mathrm{N} / \mathrm{A}$ & $\mathrm{N} / \mathrm{A}$ & $\begin{array}{l}\text { - AA } \\
\text { - ES\&HM } \\
\text { Vol. I, Part 2, } \\
\text { and Vol. V, } \\
\text { Part } 5 \\
\text { - FSP, Sect. } 2 \\
\text { - WP } \\
\text { - DAS } \\
\text { - WCM } \\
\text { - DAP } \\
\end{array}$ \\
\hline
\end{tabular}


Table 5. Feedback and Improvement (Core Function 5) Crosswalk.

\begin{tabular}{|c|c|c|c|c|c|c|}
\hline $\begin{array}{c}\text { Line } \\
\text { Management } \\
\text { Responsibility } \\
\text { for Safety }\end{array}$ & $\begin{array}{l}\text { Clear Roles and } \\
\text { Responsibilities }\end{array}$ & $\begin{array}{c}\text { Competence } \\
\text { Commensurate } \\
\text { with } \\
\text { Responsibilities }\end{array}$ & $\begin{array}{l}\text { Balanced } \\
\text { Priorities }\end{array}$ & $\begin{array}{l}\text { Identification } \\
\text { of Safety } \\
\text { Standards } \\
\text { and } \\
\text { Requirements }\end{array}$ & $\begin{array}{c}\text { Hazard } \\
\text { Controls } \\
\text { Tailored } \\
\text { to Work } \\
\text { Being } \\
\text { Performed } \\
\end{array}$ & $\begin{array}{l}\text { Operations } \\
\text { Authorization }\end{array}$ \\
\hline $\begin{array}{l}\text { - AA } \\
\text { - ES\&HM } \\
\text { Vol. I, Part 2, } \\
\text { and Vol. I, } \\
\text { Part } 5 \\
\text { - FIP } \\
\text { - SAP } \\
\text { - DNT Policy }\end{array}$ & $\begin{array}{l}\text { - AA } \\
\text { - ES\&HM } \\
\text { Vol. I, Part 2, } \\
\text { and Vol. I, } \\
\text { Part } 5 \\
\text { - FIP } \\
\text { - SAP } \\
\text { - DNT Policy } \\
\text { - WCM }\end{array}$ & $\begin{array}{l}\text { - ES\&HM } \\
\text { Vol. I, Part 2, } \\
\text { and Vol. I, } \\
\text { Part 5, and } \\
\text { Vol. IV, } \\
\text { Part 2 } \\
\text { - TAC } \\
\text { - }\end{array}$ & $\mathrm{N} / \mathrm{A}$ & N/A & $\mathrm{N} / \mathrm{A}$ & $\mathrm{N} / \mathrm{A}$ \\
\hline
\end{tabular}


This page intentionalliy left blank. 


\subsection{PROGRAM AND BUDGET EXECUTION GUIDANCE}

B332, within the Superblock operations area, is supported by four types of funding: (1) DNT programmatic funding, (2) general and administrative (G\&A) funding, (3) facility users' fees, and (4) direct charges. Programmatic funding is allocated from the DNT budget. The G\&A funding are allocated by the institution through the review of the Laboratory G\&A Funding Review Committee. The facility users' fees are negotiated between the NMT Program Leader and program users at the beginning of each fiscal year. Other services are direct charged to user programs. The Superblock also requests funding through the AD/DNT Office for the General Plant Projects (GPP) and Construction Line Item Funding. These funds, when approved, are generally used to upgrade safety structures, systems, and components (SSSCs) for the facilities.

DNT programmatic funding supports the ongoing facility operational needs including maintenance and surveillance activities, work authorization and control, and maintenance of facility documents. Programmatic funding also supports Security, the Materials Management Section (Materials Control and Accountability [MC\&A]), and the Criticality Safety Group efforts required for the Superblock.

G\&A funding and users' fees provide funding for MC\&A assurances for the Materials Management Section as well as support for MC\&A activities for legacy materials. Materials Management activities that directly support programs are direct charged to those programs.

Facility users' fees support the portion of the facility that cannot be identified directly with a single activity. These include the cost of security, MC\&A, Hazards Control, criticality safety, and other infrastructure activities and costs.

\subsection{Budget and Planning Process}

The NMT Program Leader conducts annual budget reviews for Superblock activities. The budget process is a continuous process through the fiscal year. Items related to facility staffing, maintenance, and upgrades are noted and brought up prior to the start of the next budget cycle, usually during the last quarter of the fiscal year. The facility budgets are developed by the Deputy Program Leader for Facility Operations, and are based on the safety resources needed and the expected work scope for the coming year with input from Facility Managers. Priority is given to items related to safety and maintenance work and balanced against support to programmatic users. The prioritized list is discussed with the NMT Program Leader and is balanced against other support organizations and facilities within the Superblock complex. The NMT Program Leader strives to achieve a balance between ES\&H issues, MC\&A, 'and security. Based on the input from the Superblock organizations, the NMT Program Leader prepares and submits a detailed budget plan and formal presentation to the AD/DNT, outlining the priority and rationale given for safety, security, and operational needs. (See Figure 2, next page.)

After the AD/DNT has been allocated funding for the fiscal year, budget targets and allocations are determined by balancing the needs of the DNT organization, including the Superblock. After the allocation is given to the NMT Program, the NMT Program Leader will review any pending issues and will provide the final allocation to the Superblock organizations, balancing 
ES\&H, MC\&A, and security needs. Each Superblock facility prioritizes the items that will meet the current year's activities and allocate a budget for each task. Costs are tracked and monitored according to the allocation on a monthly basis. Periodic reviews are held with the NMT Program Leader and the Deputy Program Leader for Facility Operations and the support organizations to ensure costs are tracking with work scopes and budgets.

\subsection{Roles and Responsibilities}

The AD/DNT is responsible for all programmatic, facility, and budgetary resources. Responsibility is assigned to the NMT Program Leader for the oversight and management of the Superblock resources. The NMT Program Leader ensures that there is balance achieved between ES\&H, Security, and Material Control and Accountability. Management for each of the Superblock support organizations and B332 are responsible for executing their facility mission and ensuring their programs meet milestones and objectives on budget.

\begin{tabular}{|c|c|c|}
\hline$\frac{\text { B332 ISMS Budget }}{\text { Process }}$ & $\frac{\text { NMT Program Budget }}{\text { Process }}$ & DNT Budget Process \\
\hline $\begin{array}{c}\text { Facility Budget Review } \\
\text { (Safety, maintenance, and } \\
\text { expected work scope for next } \\
\text { FY). }\end{array}$ & $\begin{array}{l}\text { NMT Program Leader reviews } \\
\text { all Superblock programs and } \\
\text { prioritizes against ES\&H, } \\
\text { Material Control and } \\
\text { Accountability, and Security } \\
\text { concerns. Negotiations of facility } \\
\text { user's fees for next FY. }\end{array}$ & $\begin{array}{l}\text { DNT Program Review for } \\
\text { next FY in Q4 (Guidance } \\
\text { and targets for program } \\
\text { leaders). }\end{array}$ \\
\hline $\begin{array}{l}\text { B332 Budget Allocation } \\
\text { Reviewed. } \\
\text { Allocations disbursed among } \\
\text { tasks for the facility based on } \\
\text { needs and priorities. }\end{array}$ & $\begin{array}{l}\text { NMT Program Budget } \\
\text { Allocations to Superblock } \\
\text { support organizations and } \\
\text { facilities. }\end{array}$ & $\begin{array}{l}\text { DNT Budget Allocations to } \\
\text { Programs in Q1. }\end{array}$ \\
\hline $\begin{array}{c}\text { Monthly reviews are } \\
\text { conducted to ensure } \\
\text { milestones and objectives are } \\
\text { being met. Input to NMT } \\
\text { Program for mid-FY review } \\
\text { and as needed. }\end{array}$ & $\begin{array}{l}\text { Mid-FY review of all Superblock } \\
\text { organizations and facilities. } \\
\text { Input provided to DNT mid-FY } \\
\text { review. }\end{array}$ & $\begin{array}{c}\text { DNT Mid-FY } \\
\text { Budget/Program Review in } \\
\text { Q3. }\end{array}$ \\
\hline $\begin{array}{l}\text { FY-End review of costs vs. } \\
\text { budgets and begin planning } \\
\text { for next FY. }\end{array}$ & $\begin{array}{l}\text { NMT Program Leader provides } \\
\text { input to DNT review from } \\
\text { Superblock organizations and } \\
\text { facilities. }\end{array}$ & $\begin{array}{c}\text { DNT Internal Program } \\
\text { Review of Current FY in } \\
\text { Q4. }\end{array}$ \\
\hline
\end{tabular}

Figure 2. Budget Process Chart. 


\subsection{STANDARDS AND REQUIREMENTS}

The B332 AA states: "The DNT Directorate and DOE/OAK acknowledge that the references cited in the SAR and the TSR documents as approved by DOE/OAK and any conditions of approval specified in the Safety Evaluation Report form the basis of the interim Work Smart Standards (WSS) for B332. These interim WSS will be superseded by the WSS applicable to B332 operations that will result from the reconciliation of the B332 interim WSS and the LLNL site-wide WSS." Attachment A to this Appendix is a current reconciliation between the Authorization Basis Standards and Orders and the WSS. The Superblock is in the process of evaluating and reconciling the interim WSS of the AA with the WSS approved site-wide. The final outcome, as described in Section 13.0 of the main body of this description, will be a revised AA for each Superblock facility that includes the site-wide WSS. 
This page intentionally left blank. 


\subsection{EVALUATING AND RESOLVING NON-COMPLIANCES}

After consensus between DOE/OAK and LLNL, noncompliances are acted upon at the institutional, facility, or activity level as operational priorities allow. Based on a graded approach, more serious noncompliances noted in LLNL's DefTrack system, as well as concerns and action items on the Facility's Master Action Database, are assigned priorities at the time of their entry into the systcm. Scc also Section 6.7 above for information on tracking and closing out noncompliances and other findings. PAAA noncompliances are tracked through the DefTrack system irrespective of their ES\&H significance. 
This page intentionally left blank. 


\subsection{FLOWDOWN OF REQUIREMENTS}

Consistent with the delineation of the flowdown of requirements (those contained in Appendix G of DOE/UC Contract 48 and nuclear safety rules) relevant to the Superblock level in the Superblock ISMS Description, B332 has developed facility-specific documentation to deal with these requirements. Table 6 presents this flowdown of requirements relevant to the B332 facility level and the corresponding B332 documentation. In the first column, those requirements relevant only to $B 332$ are listed. The second column lists LLNL documents and others that have been developed to be in compliance with the requirements. The last column lists the B332-specific implementing documents. Attachment A to this Appendix is a current reconciliation between the Authorization Basis Standards and Orders and the WSS. It identifies those areas where changes in the Authorization Basis will be required.

Table 6. B332-specific documents that implement LLNL documents and DOE and other Federal regulations.

\begin{tabular}{|c|c|c|}
\hline Requirements & $\begin{array}{l}\text { Relevant LLNL documents or } \\
\text { requirements the Superblock follows }\end{array}$ & Relevant B332 documents \\
\hline DOE Order 420.1, Facility Safety & $\begin{array}{l}\text { - LLNL ESEHM: } \\
\text {-Volume II, Part 8, "Ionizing, Non- } \\
\text { Ionizing Radiation" } \\
\text {-Volume II, Part } 10 \text { "Emergencies, } \\
\text { Earthquakes, Fire" } \\
\text { - LLNL Fire Protection Program, UCRL-MA } \\
\text { 116646 } \\
\text { - LLNL Fire Protection Engineering } \\
\text { Standards }\end{array}$ & $\begin{array}{l}\text { FSP Chaps. } 5 \text { and 9; } \\
\text { SRP B332-018 (SR 4.7.1.1); } \\
\text { SRP B332-019 (SR 4.7.1.2); } \\
\text { SRP B332-020 (SR 4.7.1.3); } \\
\text { SRP B332-021 (SR 4.7.1.4); } \\
\text { SRP B332-022 (SR 4.7.1.5); } \\
\text { SRP B332-023 (SR 4.3.3); } \\
\text { SRP B332-024 (SR 4.7.3.1); } \\
\text { SRP B332-025 (SR 4.7.3.2) }\end{array}$ \\
\hline $\begin{array}{l}\text { DOE Order 440.1A, Worker } \\
\text { Protection Management for DOE } \\
\text { Federal and Contractor Employees }\end{array}$ & $\begin{array}{l}\text { - LLNL ESEHM: } \\
\text {-Volume II, Part 2, "Chemical" } \\
\text {-Volume II, Part 12, "General Controls } \\
\text { - Procedures" } \\
\text {-Volume IV, Part 1, “Occupational } \\
\text { Health" } \\
\text {-Volume IV, Part 2, "Training" }\end{array}$ & FSP Sect. 5 \\
\hline $\begin{array}{l}\text { DOE Order 4330.4B, Maintenance } \\
\text { Management Program }\end{array}$ & $\begin{array}{l}\text { - LLNL Maintenance Implementation Plan } \\
\text { for Nonreactor Nuclear Facilities }\end{array}$ & $\begin{array}{l}\text { Plutonium Facility-Building } 332 \\
\text { Maintenance and Operations } \\
\text { Manual (MOM); WCM }\end{array}$ \\
\hline $\begin{array}{l}\text { DOE Order } 5400.1, \text { General } \\
\text { Environmental Protection } \\
\text { Program }\end{array}$ & - $L L N L$ ESEHM, Volume III & FSP Sect. 6 and $\Lambda$ pps. G and I \\
\hline $\begin{array}{l}\text { DOE Order 5480.1B (Ch. 5), } \\
\text { Environmental, Safety and Health } \\
\text { Program }\end{array}$ & - LLNL ESEHM & FSP Sect. 6 and Apps. G and I \\
\hline $\begin{array}{l}\text { DOE Order } 5480.3 \text {, Safety } \\
\text { Requirements for the Packaging } \\
\text { and Transportation of Hazardous } \\
\text { Materials }\end{array}$ & $\begin{array}{l}\text { - LLNL Onsite Hazardous Materials } \\
\text { Packaging and Transportation Safety } \\
\text { Manual }\end{array}$ & FSP App. H \\
\hline $\begin{array}{l}\text { DOE Order } 5480.4 \text { (Ch. } 4 \text { ), } \\
\text { Environmental Protection, Safety } \\
\text { and Health Protection Standards }\end{array}$ & - LLNL ESEHM & FSP Sect. 6 and Apps. G, H, and I \\
\hline $\begin{array}{l}\text { DOE Order } 5480.19 \text { (Ch. 1), } \\
\text { Conduct of Operations } \\
\text { Requirements for DOE Facilities }\end{array}$ & $\begin{array}{l}\text { - LLNL ESEHM, Volume 1, Part 2, "ES\&H } \\
\text { Management Requirements" }\end{array}$ & $\begin{array}{l}\text { TSR; FSP; QA Plan; ACPs; SRPs; } \\
\text { FOPs; B332 } 2.19 \text { Workbook; } \\
\text { MOM; OPs }\end{array}$ \\
\hline
\end{tabular}

(table continued next page) 
Table 6. B332-specific documents that implement LLNL documents and DOE and other Federal regulations. (continued)

\begin{tabular}{|c|c|c|}
\hline Requirements & $\begin{array}{l}\text { Relevant LLNL documents or } \\
\text { requirements the Superblock follows }\end{array}$ & Relevant B332 documents \\
\hline $\begin{array}{l}\text { DOE Order 5480.20A, Personnel } \\
\text { Selection, Qualification, and } \\
\text { Training Requirements for DOE } \\
\text { Nuclear Facilities }\end{array}$ & $\begin{array}{l}\text { - LLNL ESEHM: } \\
\text {-Volume 1, Part 2, "ES\&H } \\
\text { Management Requirements" } \\
\text { —Volume V, Part 1, "Personnel" } \\
\text { - LLNL Defense Systems/Nuclear Design } \\
\text { Directorate Training Plan } \\
\end{array}$ & $\begin{array}{l}\text { B332 Training Implementation } \\
\text { Matrix; LLNL Plutonium Facility } \\
\text { Personnel Selection, Qualification, } \\
\text { and Training Plan }\end{array}$ \\
\hline $\begin{array}{l}\text { DOE Order 5480.21, Unreviewed } \\
\text { Safety Questions }\end{array}$ & $\begin{array}{l}\text { - LLNL ESEHM: } \\
\text {-Volume 1, Part 2, "ES\&H } \\
\text { Management Requirements" } \\
\text {-Volume V, Part 2, "Procedures" }\end{array}$ & ACP-B332-011 \\
\hline $\begin{array}{l}\text { DOE Order } 5480.22 \text { (Ch. 1), } \\
\text { Technical Safety Requirements }\end{array}$ & $\begin{array}{l}\text { - LLNL ESEHM: } \\
\text {-Volume 1, Part 2, "ES\&H } \\
\text { Management Requirements" } \\
\text {-Volume V, Part 2, "Procedures" }\end{array}$ & $\begin{array}{l}\text { TSR; QA Plan; ACPs; SRPs; } \\
\text { FOPs; QIPs; QOPs }\end{array}$ \\
\hline $\begin{array}{l}\text { DOE Order } 5480.23(\mathrm{Ch} .1) \\
\text { Nuclear Safety Analysis Report }\end{array}$ & $\begin{array}{l}\text { - LLNL ESEHM: } \\
\text {-Volume 1, Part 2, "ES\&H } \\
\text { Management Requirements" } \\
\text {-Volume V, Part 2, "Procedures" } \\
\text { - DOE-STD-3009, Preparation Guide for } \\
\text { U.S. DOE Nonreactor Nuclear Facility } \\
\text { Safcty Analysis Reports, draft, 4/94 } \\
\text { - DOE-STD-1027, Guidance on Preliminary } \\
\text { Hazard Classification and Accident } \\
\text { Analysis Techniques for Compliance with } \\
\text { DOE 5430.23 Nuclear Safety Analysis } \\
\text { Report } \\
\text { - DOE-STD-1104, Guidance on Preliminary } \\
\text { Hazard Classification and Accident Review } \\
\text { and Approval of Nonreactor Nuclear } \\
\text { Facility Safety Analysis Report }\end{array}$ & Authorization Agreement \\
\hline $\begin{array}{l}\text { DOE Order } 5480.31 \text {, Startup and } \\
\text { Restart of Nuclear Facilities }\end{array}$ & $\begin{array}{l}\text { - LLNL ESEHM: } \\
\text {-Volume 1, Part 2, "ES\&H } \\
\text { Management Requirements" } \\
\text {-Volume V, Part 5, "Facilities" }\end{array}$ & ACP-B332-001, -005,-017; QIP 5 \\
\hline $\begin{array}{l}\text { DOE Order 5482.1B, Environment, } \\
\text { Safety, and Health Appraisal } \\
\text { Program }\end{array}$ & $\begin{array}{l}\text { - LLNL ESEHM: } \\
\text {-Volume 1, Part 2, "ES\&H } \\
\text { Management Requirements" } \\
\text {-Volume I, Part 5, "Feedback and } \\
\text { Improvement" } \\
\text {-Volume II, Part 12, "General Controls } \\
\text { - Procedures" } \\
\text { - DNT Environmental, Safety and Health } \\
\text { Self-Assessment Plan }\end{array}$ & NMTP FIP \\
\hline $\begin{array}{l}\text { DOE Order 5484.1, Environmental } \\
\text { Protection, Safety, and Health } \\
\text { Protection Information Reporting } \\
\text { Requirements }\end{array}$ & $\begin{array}{l}\text { - LLNL ESEHM: } \\
\text { - Volume I, Part 5, "Feedback and } \\
\text { Improvement" } \\
\text { - Volume II, Part 10, Emergencies, } \\
\text { Earthquakes, Fire" }\end{array}$ & NMTP FIP \\
\hline
\end{tabular}


Table 6. B332-specific documents that implement LLNL documents and DOE and other Federal regulations. (continued)

\begin{tabular}{|c|c|c|}
\hline Requirements & $\begin{array}{l}\text { Relevant LLNL documents or } \\
\text { requirements the Superblock follows }\end{array}$ & Relevant B332 documents \\
\hline $\begin{array}{l}\text { DOE Order 5820.2A, Radioactive } \\
\text { Waste Management }\end{array}$ & $\begin{array}{l}\text { - LLNL Waste Acceptance Criteria } \\
\text { - LLNL TRU Waste Program Certification } \\
\text { and Quality Assurance Plan } \\
\text { - LLNI. Low-Level Waste Program } \\
\text { Certification and Quality Assurance Plan } \\
\text { - LLNL Guidelines for Waste Accumulation } \\
\text { Area } \\
\text { - Defense E Nuclear Technologies Directorate } \\
\text { Waste Minimization and Pollution } \\
\text { Prevention Plan }\end{array}$ & $\begin{array}{l}\text { FSP Sect. } 6 \text { and Apps. D, G, H, } \\
\text { and I }\end{array}$ \\
\hline $\begin{array}{l}\text { 10 CFR 830.120, Quality Assurance } \\
\text { DOE Order 5700.6C, Quality } \\
\text { Assurance }\end{array}$ & $\begin{array}{l}\text { - Quality Assurance Plan for Nuclear } \\
\text { Facilities, Rev 4, and LLNL [PAAA] } \\
\text { Implementation Plan, Rev 4. } \\
\text { - LLNL Quality Assurance Program } \\
\text { - Defense and Nuclear Technologies } \\
\text { Directorate Quality Assurance Plan }\end{array}$ & $\begin{array}{l}\text { B332 QAP; QIPs; QOPs; } \\
\text { NMTP FIP }\end{array}$ \\
\hline $\begin{array}{l}\text { 10 CFR 835: Occupational } \\
\text { Radiation Protection } \\
\text { DOE Order } 5400.5 \text { (Ch. 2), } \\
\text { Radiation Protection of the Public } \\
\text { and the Fnvironment }\end{array}$ & $\begin{array}{l}\text { - LLNL ESEHM: } \\
\text {-Volume II, Part 8, "Ionizing, Non- } \\
\text { Ionizing Radiation" } \\
\text { —Volume II, Part 10, "Emergencies, } \\
\text { Earthquakes, Fire" }\end{array}$ & TSR; FSP Sect. 5; OSPs \\
\hline
\end{tabular}


This page intentionally left blank. 


\subsection{IMPLEMENTATION TASKS, SCHEDULE, AND MILESTONES}

Consistent with Section 14.0 of the Superblock ISM Description, the following tasks, schedule, and milestones have been established for B332:

- Complete corrective actions for B332 ISMSV. (December 1999)

- Performance Measures implemented. (December 1999)

- Reconciliation of Site-wide ISMS and Superblock Nuclear Facilities ISMS. (Superblock Management will provide reconciliation plan within three months after Site-wide Phase II Verification.)

- Complete full implementation of FOPs for safety-significant SSCs. (June 2000)

- Reconciliation of LLNL WSS and B332 interim WSS. (June 2000) 
This page intentionally left blank. 


\section{ATTACHMENT A}

\section{PLUTONIUM FACILITY WORK SMART STANDARDS RECONCILIATION}

\begin{tabular}{|c|c|c|c|c|}
\hline $\begin{array}{l}\text { B332 SAR Basis } \\
\text { [SAR Chapter \# in Brackets] }\end{array}$ & $\begin{array}{l}\text { Current } \\
\text { Status of } \\
\text { Each } \\
\text { Order, } \\
\text { Standard, } \\
\text { etc. }\end{array}$ & $\begin{array}{l}\text { If Order, } \\
\text { Standard, } \\
\text { etc., } \\
\text { Cancelled or } \\
\text { Superseded, } \\
\text { Replaced by }\end{array}$ & $\begin{array}{l}\text { Latest } \\
\text { Version In } \\
\text { LLNL } \\
\text { Contract/ } \\
\text { WSS? }\end{array}$ & $\begin{array}{l}\text { Auth. } \\
\text { Basis } \\
\text { Change? } \\
\text { Yes/No }\end{array}$ \\
\hline $\begin{array}{l}\text { DOE Order 1324.2A, Records Disposition (April 1992) } \\
{[7,14]}\end{array}$ & $\begin{array}{l}\text { Cancelled } \\
\text { by DOE }\end{array}$ & 21 CFR 1002 & Yes & Yes \\
\hline $\begin{array}{l}\text { DOE Order 1540.2, Hazardous Material Packaging for } \\
\text { Transport-Administrative Procedures (December 1988) [3] }\end{array}$ & $\begin{array}{l}\text { Cancelled } \\
\text { by DOE }\end{array}$ & $\begin{array}{l}\text { O } 460.2 \\
\text { Chg. } 1\end{array}$ & Yes & Yes \\
\hline $\begin{array}{l}\text { DOE Order 4330.4B, Maintenance Management Program } \\
\text { (May 1992) }[3,10,14,17]\end{array}$ & $\begin{array}{l}\text { Still } \\
\text { Current }\end{array}$ & & Yes & No \\
\hline $\begin{array}{l}\text { DOF Order 4700.1, Project Management System } \\
\text { (March 1987) [14] }\end{array}$ & Superseded & $\mathrm{O} 430.1 \mathrm{~A}$ & Yes & Yes \\
\hline $\begin{array}{l}\text { DOE Order 5000.3B, Ch. 1, Occurrence Reporting and } \\
\text { Processing Operations Information (July 1993) }[3,5,6,7,11 \text {, } \\
13,15,17]\end{array}$ & Superseded & O 232.1A & Yes & Yes \\
\hline $\begin{array}{l}\text { DOE Order 5400.1, General Environmental Protection } \\
\text { Program (June 1990) }[3,9]\end{array}$ & $\begin{array}{l}\text { Partially } \\
\text { Cancelled } \\
\text { by DOE }\end{array}$ & O 232.1A & Yes & Yes \\
\hline $\begin{array}{l}\text { DOE Order 5400.3A, Hazardous and Radioactive Mixed } \\
\text { Waste Program (February 1989) [16] }\end{array}$ & $\begin{array}{l}\text { Cancelled } \\
\text { by DOE }\end{array}$ & O 5820.2A & Yes & No \\
\hline $\begin{array}{l}\text { DOE Order 5400.5, Radiation Protection of the Public and } \\
\text { the Environment (Ch. 2, January 1993) }[1,2,3,7,16]\end{array}$ & $\begin{array}{l}\text { Partially } \\
\text { Cancelled } \\
\text { by DOE }\end{array}$ & $\begin{array}{l}\text { O } 232.1 \mathrm{~A} \\
\text { [O231.1 } \\
\text { Chg. } 1 \\
\text { removed } \\
\text { para } 1 \mathrm{a}(3) \text { of } \\
\text { Ch. II] }\end{array}$ & Yes & Yes \\
\hline $\begin{array}{l}\text { DOE Order 5480.1B, Environmental, Safety, and Health } \\
\text { Program (Ch. 5, May 1993) [3] }\end{array}$ & $\begin{array}{l}\text { Cancelled } \\
\text { by DOE }\end{array}$ & $?$ & No & No \\
\hline $\begin{array}{l}\text { DOE Order 5480.3, Safety Requirements for the Packaging } \\
\text { and Transportation of Hazardous Materials, Hazardous } \\
\text { Substances, and Hazardous Wastes (July 1985) }[3,16]\end{array}$ & $\begin{array}{l}\text { Cancelled } \\
\text { by DOE }\end{array}$ & $\begin{array}{l}\text { [Per O 232.1 } \\
\text { Chg. 1, } \\
\text { removed } \\
\text { para 9e] }\end{array}$ & No & No \\
\hline $\begin{array}{l}\text { DOE Order 5480.4, Environmental Protection, Safety and } \\
\text { Health Protection Standards (Ch. 4, December 1998) [1, 2,3, } \\
4,5,6,8,14,16] \\
\text { [Note: Per O 440.1, cancel Attach 2, para 2c, 2d(2)-(3), 2e(1)- } \\
\text { (8), and Attach 3, para 2c, 2d(2)-(3) and 2e(1)-(7)] }\end{array}$ & $\begin{array}{l}\text { Partially } \\
\text { Cancelled } \\
\text { by DOE }\end{array}$ & $\mathrm{O} 440.1 \mathrm{~A}$ & $\begin{array}{c}\text { Yes } \\
j\end{array}$ & Yes \\
\hline $\begin{array}{l}\text { DOE Order 5480.7 A, Fire Protection (February 1993) }[2,3,4 \text {, } \\
\text { 11] }\end{array}$ & $\begin{array}{l}\text { Cancelled } \\
\text { by DOE }\end{array}$ & $\begin{array}{l}\text { Part O 420.1 } \\
\text { Part } 440.1 \mathrm{~A}\end{array}$ & $\begin{array}{l}\text { Yes } \\
\text { Yes }\end{array}$ & $\begin{array}{l}\text { Yes } \\
\text { Yes }\end{array}$ \\
\hline $\begin{array}{l}\text { DOE Order 5480.8A, Ch. 1, Contractor Occupational } \\
\text { Medical Program (Óctober 1992) }[3,8]\end{array}$ & $\begin{array}{l}\text { Cancelled } \\
\text { by DOE }\end{array}$ & $\mathrm{O} 440.1 \mathrm{~A}$ & Yes & Yes \\
\hline
\end{tabular}




\begin{tabular}{|c|c|c|c|c|}
\hline $\begin{array}{l}\text { DOE Order 5480.10, Contractor Industrial Hygiene } \\
\text { Program (June 1985) }[3,6,8,11,15,16]\end{array}$ & $\begin{array}{l}\text { Cancelled } \\
\text { by DOE }\end{array}$ & $\mathrm{O} 440.1 \mathrm{~A}$ & Yes & Yes \\
\hline $\begin{array}{l}\text { DOE Order 5480.11, Radiation Protection for Occupational } \\
\text { Workers (June 1992) }[2,3,15,16]\end{array}$ & $\begin{array}{l}\text { Cancelled } \\
\text { by DOE }\end{array}$ & 10 CFR 835 & Yes & Yes \\
\hline $\begin{array}{l}\text { DOE Order 5480.15, DOE Laboratory Accreditation } \\
\text { Program for Personnel Dosimetry (December 1987) }[3,7]\end{array}$ & $\begin{array}{l}\text { Cancelled } \\
\text { by DOE }\end{array}$ & 10 CFR 835 & Yes & Yes \\
\hline $\begin{array}{l}\text { DOE Order 5480.19, Conduct of Operations Requirements } \\
\text { for DOE Facilities (May 1992) }[3,10,11,12,13,14,17]\end{array}$ & $\begin{array}{l}\text { Still } \\
\text { Current }\end{array}$ & $\begin{array}{l}\text { O } 5480.19 \\
\text { Ch: } 1\end{array}$ & Yes & Yes \\
\hline $\begin{array}{l}\text { DOE Order } 5480.20 A \text {, Personnel Selection, Qualification, } \\
\text { and Training Requirements for DOE Nuclear Pacilities } \\
\text { (September 1995) }[3,6,7,11,12,13,17]\end{array}$ & $\begin{array}{l}\text { Still } \\
\text { Current }\end{array}$ & & Yes & No \\
\hline $\begin{array}{l}\text { DOE Order 5480.21, Unreviewed Safety Questions } \\
\text { (November 1992) }[3,5,11,13,17]\end{array}$ & $\begin{array}{l}\text { Still } \\
\text { Current }\end{array}$ & & Yes & No \\
\hline $\begin{array}{l}\text { DOE Order 5480.22, Technical Safety Requirements (Ch. 1, } \\
\text { September 1992) }[3,5,6,10,11,12,13]\end{array}$ & Superseded & $\begin{array}{l}\text { O } 5480.22 \\
\text { Ch. } 2\end{array}$ & Yes & Yes \\
\hline $\begin{array}{l}\text { DOE Order 5480.23, Nuclear Safety Analysis Reports } \\
\text { (Ch. 1, April 1992) }[1,2,3,4,5,6,8,10,11,13]\end{array}$ & Superseded & $\begin{array}{l}\text { O } 5480.3 \\
\text { Ch. } 1\end{array}$ & Yes & Yes \\
\hline $\begin{array}{l}\text { DOE Order 5480.24, Nuclear Criticality Safety } \\
\text { (August 1992) }[3,4,5,6,11]\end{array}$ & $\begin{array}{l}\text { Cancelled } \\
\text { by DOE }\end{array}$ & O 420.1 & Yes & Yes \\
\hline $\begin{array}{l}\text { DOE Order 5480.28, Natural Phenomena Hazards } \\
\text { Mitigation (January 1993) }[1,3,5]\end{array}$ & $\begin{array}{l}\text { Cancelled } \\
\text { by DOE }\end{array}$ & O 420.1 & Yes & Yes \\
\hline $\begin{array}{l}\text { DOE Order 5480.31, Startup and Restart of Nuclear } \\
\text { Facilities (September 1993) }[3,5,11]\end{array}$ & $\begin{array}{l}\text { Cancelled } \\
\text { by DOE }\end{array}$ & $\mathrm{O} 425.1 \mathrm{~A}$ & Yes & Yes \\
\hline $\begin{array}{l}\text { DOE Order 5481.1B, Safety Analysis and Review } \\
\text { (May 1987) }[1,2]\end{array}$ & $\begin{array}{l}\text { Cancelled } \\
\text { by DOE }\end{array}$ & $\begin{array}{l}\text { Repl by SAN } \\
\text { MD 5481.1A }\end{array}$ & Yes & Yes \\
\hline $\begin{array}{l}\text { DOE Order 5482.1B, Environment, Safety, and Health } \\
\text { Appraisal Program (November 1992) [3] }\end{array}$ & $\begin{array}{l}\text { Cancelled } \\
\text { by DOE }\end{array}$ & & No & No \\
\hline $\begin{array}{l}\text { DOE Order 5483.1A, Occupational Safety and Health } \\
\text { Program for DOE Contractor Employees at Government- } \\
\text { Owned, Contractor-Operated Facilities (June 1983) [3] }\end{array}$ & $\begin{array}{l}\text { Cancelled } \\
\text { by DOE }\end{array}$ & $\mathrm{O} 440.1 \mathrm{~A}$ & Yes & Yes \\
\hline $\begin{array}{l}\text { DOE Order 5484.1, Environmental Protection, Safety, and } \\
\text { Health Protection Information Reporting Requirements } \\
\text { (October 1990) [3] }\end{array}$ & $\begin{array}{l}\text { Cancelled } \\
\text { by DOE }\end{array}$ & O $231.1 \mathrm{Ch} .2$ & Yes & Yes \\
\hline $\begin{array}{l}\text { DOE Order 5500.1B, Emergency Management System } \\
\text { (February 1992) }[3,11]\end{array}$ & $\begin{array}{l}\text { Cancelled } \\
\text { by DOE }\end{array}$ & O $151.1 \mathrm{Ch} .2$ & Yes & Yes \\
\hline $\begin{array}{l}\text { DOE Order 5500.2B, Emergency Categories, Classes, and } \\
\text { Notification and Reporting Requirements (February 1992) } \\
{[3,11,15]}\end{array}$ & $\begin{array}{l}\text { Cancelled } \\
\text { by DOE }\end{array}$ & O $151.1 \mathrm{Ch} .2$ & Yes & Yes \\
\hline $\begin{array}{l}\text { DOE Order 5500.3A, Planning and Preparedness for } \\
\text { Operational Emergencies (February 1992) }[3,11,15]\end{array}$ & $\begin{array}{l}\text { Cancelled } \\
\text { by DOE }\end{array}$ & O $151.1 \mathrm{Ch} .2$ & Yes & Yes \\
\hline $\begin{array}{l}\text { DOE Order 5500.4A, Public Affairs Policy and Planning } \\
\text { Requirements for Emergencies (June 1992) }[3,11,15]\end{array}$ & $\begin{array}{l}\text { Cancelled } \\
\text { by DOE }\end{array}$ & O $151.1 \mathrm{Ch} .2$ & Yes & Yes \\
\hline $\begin{array}{l}\text { DOE Order 5500.7B, Emergency Operating Records } \\
\text { Protection Program (July 1992) [11] }\end{array}$ & $\begin{array}{l}\text { Cancelled } \\
\text { by DOE }\end{array}$ & O $151.1 \mathrm{Ch} .2$ & Yes & Yes \\
\hline $\begin{array}{l}\text { DOE Order 5500.9A, Emergency Planning, Preparedness, } \\
\text { and Response to Continuity of Government Emergencies } \\
\text { (July 1992) [3] }\end{array}$ & $\begin{array}{l}\text { Cancelled } \\
\text { by DOE }\end{array}$ & O 151.1 Ch. 2 & Yes & Yes \\
\hline $\begin{array}{l}\text { DOE Order 5500.10, Emergency Readiness Assurance } \\
\text { Program (February 1992) [3, 11, 15] }\end{array}$ & $\begin{array}{l}\text { Cancelled } \\
\text { by DOE }\end{array}$ & O $151.1 \mathrm{Ch} .2$ & Yes & Yes \\
\hline $\begin{array}{l}\text { DOE Order 5530.3, Radiological Assistance Program } \\
\text { (January 1992) [3] }\end{array}$ & $\begin{array}{l}\text { Still } \\
\text { Current }\end{array}$ & & Yes & No \\
\hline
\end{tabular}


Appendix A: B332 ISMS

\begin{tabular}{|c|c|c|c|c|}
\hline $\begin{array}{l}\text { DOE Order 5530.5, Ch. 1, Federal Radiological and } \\
\text { Monitoring Assessment Center (December 1992) [3] }\end{array}$ & $\begin{array}{l}\text { Still } \\
\text { Current }\end{array}$ & & Yes & No \\
\hline $\begin{array}{l}\text { DOE Order 5610.1, Packaging and Transporting of Nuclear } \\
\text { Explosives, Nuclear Components, and Special Assemblies } \\
\text { (September 1979) [3] }\end{array}$ & $\begin{array}{l}\text { Cancelled } \\
\text { by DOE }\end{array}$ & $?$ & No & No \\
\hline $\begin{array}{l}\text { DOE Order 5632.8, Protection Program Operations: System } \\
\text { Performance Tests (February 1988) [15] }\end{array}$ & $\begin{array}{l}\text { Cancelled } \\
\text { by DOE }\end{array}$ & $?$ & No & No \\
\hline $\begin{array}{l}\text { DOE Order 5633.3A, Control and Accountability of Nuclear } \\
\text { Material (February 1993) }[3,15]\end{array}$ & Superseded & O $474.18 / 99$ & Yes & Yes \\
\hline $\begin{array}{l}\text { DOE Order } 5700.6 \mathrm{C} \text {, Quality Assurance (August 1991) }[2,3 \text {, } \\
4,9,11,14,17]\end{array}$ & $\begin{array}{l}\text { Same as } \\
10 \text { CFR } \\
830.120 \& \\
\text { O } 414.1\end{array}$ & $\begin{array}{l}\text { 10 CFR } \\
830.120\end{array}$ & Yes & Yes \\
\hline $\begin{array}{l}\text { DOE Order 5820.2A, Radioactive Waste Management } \\
\text { (September 1988) }[3,9,16]\end{array}$ & $\begin{array}{l}\text { Still } \\
\text { Current }\end{array}$ & & Yes & No \\
\hline $\begin{array}{l}\text { DOE Order } 6430.1 \mathrm{~A} \text {, General Design Criteria (April 1989) } \\
\text { (Will be rewritten into DOE MD.) }[1,2,3,4,5,7,11,13,14 \text {, } \\
\text { 16] }\end{array}$ & $\begin{array}{l}\text { Cancelled } \\
\text { except for } \\
\text { DNFSB } \\
\text { Facilities }\end{array}$ & & No & No \\
\hline \multicolumn{5}{|l|}{ DOE Standards \& Guidance } \\
\hline $\begin{array}{l}\text { DOE-STD-1004-92, Root Cause Analysis Guidance (1992) } \\
\text { [11] }\end{array}$ & $\begin{array}{c}\text { Still } \\
\text { Current }\end{array}$ & & No & No \\
\hline $\begin{array}{l}\text { DOE-STD-1020-94, "Natural Phenomena Hazards and } \\
\text { Evaluation Criteria for DOE Facilities" (April 1994) }[1,3,4 \text {, } \\
\text { 5] }\end{array}$ & Superseded & $\begin{array}{l}\text { STD } 1020-94 \\
\text { Ch. } 1\end{array}$ & Yes & Yes \\
\hline $\begin{array}{l}\text { DOE-STD-1021-93, "Performance Categorization Criteria } \\
\text { for Structures, Systems, and Components at DOE Facilities } \\
\text { Subjected to Natural Phenomena Hazards" (July 1993) [1, 4, } \\
\text { 5] }\end{array}$ & Superseded & $\begin{array}{l}\text { STD } 1021-93 \\
\text { Ch. } 1\end{array}$ & Yes & Yes \\
\hline $\begin{array}{l}\text { DOE-STD-1022-94, "Natural Phenomena Hazards Site } \\
\text { Characterization Criteria" (March 1994) [1] }\end{array}$ & Superseded & $\begin{array}{l}\text { STD } 1022-94 \\
\text { Ch. } 1\end{array}$ & Yes & Yes \\
\hline $\begin{array}{l}\text { DOE-STD-1024-92, "Guidelines for Use of Probabilistic } \\
\text { Seismic Hazard Curves at DOE Sites" (December 1992) [1] }\end{array}$ & $\begin{array}{l}\text { Still } \\
\text { Current }\end{array}$ & & No & No \\
\hline $\begin{array}{l}\text { DOE-STD-1027-92 Chg. } 1 \text { Hazard Categorization and } \\
\text { Accident Analysis Techniques for Compliance with DOE } \\
\text { Order 5480.23, Nuclear Salety Analysis Reports 1992 [3] }\end{array}$ & $\begin{array}{l}\text { Still } \\
\text { Current }\end{array}$ & & Yes & No \\
\hline $\begin{array}{l}\text { DOE-STD-3009-93, Draft, Preparation Guide for U.S. } \\
\text { Department of Energy Nonreactor Nuclear Facility Safety } \\
\text { Analysis Reports (March 1994) }[3,5,13]\end{array}$ & Superseded & STD-3009-95 & No & No \\
\hline $\begin{array}{l}\text { DOE-STD-3013-96 Criteria for Preparing and Packaging } \\
\text { Plutonium Metals and Oxides for Long-Term Storage }\end{array}$ & $\begin{array}{l}\text { Still } \\
\text { Current }\end{array}$ & & Yes & No \\
\hline $\begin{array}{l}\text { DOE-SAN MD 5481.1A, Safety Analysis and Review } \\
\text { System [2] }\end{array}$ & $\begin{array}{l}\text { Still } \\
\text { Current }\end{array}$ & & Yes & No \\
\hline $\begin{array}{l}\text { DOE/TP20-11, General Fire Fighting Guidance for Nuclear } \\
\text { Weapons [3] }\end{array}$ & $\begin{array}{l}\text { Still } \\
\text { Current }\end{array}$ & & No & No \\
\hline $\begin{array}{l}\text { DOE DP-62, Document of Example Technical Safety } \\
\text { Requirements, Rev. No. } 0 \text { (November, 1993) [5] }\end{array}$ & $\begin{array}{l}\text { Still } \\
\text { Current }\end{array}$ & & No & No \\
\hline $\begin{array}{l}\text { DOE DP-62 TSR, Interpretation Guide for the Document of } \\
\text { TSR Examples, draft (May 24, 1993) [5] }\end{array}$ & Superseded & $\begin{array}{l}\text { Draft of } \\
5 / 95, \text { R } 1\end{array}$ & No & No \\
\hline $\begin{array}{l}\text { DOE-DP-STD-3005-YR, Draft, Evaluation Guidelines for } \\
\text { Accident Analysis and Safety Structure, Systems, and } \\
\text { Components }(1994)[3,5,13]\end{array}$ & Superseded & $\begin{array}{l}\text { STD-3009-94, } \\
\text { App. A }\end{array}$ & No & No \\
\hline
\end{tabular}




\begin{tabular}{|c|c|c|c|c|}
\hline $\begin{array}{l}\text { DOE, Implementation Guidance for Use with Title } 10 \\
\text { CFR } 835 \text { (December 1993) [7] }\end{array}$ & $\begin{array}{l}\text { Still } \\
\text { Current }\end{array}$ & & No & No \\
\hline $\begin{array}{l}\text { DOE/EH-0256T (Rev. 1), U.S. DOE Radiological Control } \\
\text { Manual (April 1994) [7] }\end{array}$ & $\begin{array}{l}\text { Still } \\
\text { Current }\end{array}$ & & No & No \\
\hline $\begin{array}{l}\text { DOE/EV-0043, Standard on Fire Protection for Portable } \\
\text { Structures [3] }\end{array}$ & Superseded & STD-1088-95 & No & No \\
\hline $\begin{array}{l}\text { DOE/EV-005/1, "Electrical Safety Criteria for Research and } \\
\text { Development Activities" [11] }\end{array}$ & $\begin{array}{l}\text { Still } \\
\text { Current }\end{array}$ & & No & No \\
\hline $\begin{array}{l}\text { DOE/EV-1830-T5, A Guide to Reducing Radiation } \\
\text { Exposure to As Low As Reasonably Achievable (ALARA), } \\
\text { U.S. Department of Energy (1980) [7] }\end{array}$ & $\begin{array}{l}\text { Still } \\
\text { Current }\end{array}$ & & $\mathrm{C}$ & No \\
\hline $\begin{array}{l}\text { Nuclear STD NE F3-45T, Specifications for HEPA Filters } \\
\text { Used by DOE Contractors (August 1984) }[4,5]\end{array}$ & Superseded & STD-3020-97 & Yes & Yes \\
\hline \multicolumn{5}{|l|}{ DOE Emergency Management Guides } \\
\hline $\begin{array}{l}\text { Guidance for Emergency Readiness Assurance Plans (ERAP) } \\
(7 / 23 / 93) \text { [15] }\end{array}$ & $\begin{array}{l}\text { Still } \\
\text { Current }\end{array}$ & & No & No \\
\hline $\begin{array}{l}\text { Emergency Readiness Assurance Oversight Appraisal Criteria } \\
(12 / 9 / 91) \text { [15] }\end{array}$ & $\begin{array}{l}\text { Still } \\
\text { Current }\end{array}$ & & No & No \\
\hline $\begin{array}{l}\text { Guidance for Emergency Response Drills and Exercises } \\
(12 / 11 / 91)[15]\end{array}$ & Superseded & O $151.1 \mathrm{Ch} .2$ & Yes & Yes \\
\hline $\begin{array}{l}\text { Standard Format and Content for Emergency Plans }(12 / 11 / 91) \\
\text { [15] }\end{array}$ & Superseded & O $151.1 \mathrm{Ch} .2$ & Yes & Yes \\
\hline Emergency Exercise Evaluation Criteria $(12 / 11 / 91)[15]$ & Superseded & O $151.1 \mathrm{Ch} .2$ & Yes & Yes \\
\hline Program Administration (12/11/91) [15] & Superseded & O $151.1 \mathrm{Ch} .2$ & Yes & Yes \\
\hline Guidance for Hazards Assessment (6/26/92) [15] & Superseded & O $151.1 \mathrm{Ch} .2$ & Yes & Yes \\
\hline $\begin{array}{l}\text { Event Classification and Emergency Action Levels (6/26/92) } \\
\text { [15] }\end{array}$ & Superseded & O $151.1 \mathrm{Ch} .2$ & Yes & Yes \\
\hline $\begin{array}{l}\text { Interim Guidance for Emergency Medical Support }(6 / 26 / 92) \\
\text { [15] }\end{array}$ & Superseded & O $151.1 \mathrm{Ch} .2$ & Yes & Yes \\
\hline Consequence Assessment (7/28/92) [15] & Superseded & O $151.1 \mathrm{Ch} .2$ & Yes & Yes \\
\hline Interim Guidance for Notification (7/26/92) [15] & Superseded & O $151.1 \mathrm{Ch} .2$ & Yes & Yes \\
\hline $\begin{array}{l}\text { Interim Guidance for Emergency Management Training } \\
(7 / 26 / 92)[15]\end{array}$ & Superseded & O $151.1 \mathrm{Ch} .2$ & Yes & Yes \\
\hline Interim Guidance for Protective Actions (6/1/93) [15] & Superseded & O $151.1 \mathrm{Ch} .2$ & Yes & Yes \\
\hline Interim Guidance for Reentry and Recovery $(6 / 1 / 93)$ [15] & Superseded & O 151.1 Ch. 2 & Yes & Yes \\
\hline \multicolumn{5}{|l|}{ Federal Codes, Standards, and Regulations } \\
\hline $\begin{array}{l}10 \text { CFR } 20, N R C \text { Standards for Protection Against Radiation, } \\
\text { Nuclear Regulatory Commission }(.2003 \text { only) }[1,2,11]\end{array}$ & $\begin{array}{l}\text { Still } \\
\text { Current }\end{array}$ & & Yes & No \\
\hline $\begin{array}{l}\text { 10 CFR 71, Packaging of Radioactive Materials for Transport } \\
{[3,9]}\end{array}$ & $\begin{array}{l}\text { Still } \\
\text { Current }\end{array}$ & & Yes & No \\
\hline 10 CFR 100, NRC Reactor Siting Guide [1] & Superseded & Rev. 1/97 & No & No \\
\hline 10 CFR 830.120, Quality Assurance $[3,4,14]$ & $\begin{array}{l}\text { Still } \\
\text { Current }\end{array}$ & & Yes & No \\
\hline $\begin{array}{l}\text { 10 CFR 835, Radiation Protection for Occupational Workers } \\
{[1,3,4,5,7]}\end{array}$ & $\begin{array}{l}\text { Still } \\
\text { Current }\end{array}$ & & Yes & No \\
\hline
\end{tabular}


Appendix A: B332 ISMS

\begin{tabular}{|c|c|c|c|}
\hline 29 CFR 1910, OSHA Standards $[2,3,4,5,8,11]$ & $\begin{array}{l}\text { Still } \\
\text { Current }\end{array}$ & Yes & No \\
\hline $\begin{array}{l}29 \text { CFR 1960, Safety and Health Provisions for Federal } \\
\text { Employees [3] }\end{array}$ & $\begin{array}{c}\text { Still } \\
\text { Current }\end{array}$ & No & No \\
\hline $\begin{array}{l}40 \text { CFR 61, Subpart A, National Emission Standards for } \\
\text { Hazardous Air Pollutants (NESHAP) }[2,7]\end{array}$ & $\begin{array}{l}\text { Still } \\
\text { Current }\end{array}$ & Yes & No \\
\hline 40 CFR 260, Hazardous Waste Management System $[3,9]$ & $\begin{array}{l}\text { Still } \\
\text { Current }\end{array}$ & Yes & No \\
\hline $\begin{array}{l}49 \text { CFR 100-199, Department of Transportation Hazardous } \\
\text { Materials Regulations (DOT) [3] }\end{array}$ & $\begin{array}{l}\text { Still } \\
\text { Current }\end{array}$ & Yes & No \\
\hline $\begin{array}{l}49 \text { CFR } 172 \text { (latest revision) (Included in } 49 \text { CFR 100-199?) } \\
\text { [9] }\end{array}$ & $\begin{array}{l}\text { Still } \\
\text { Current }\end{array}$ & Yes & No \\
\hline $\begin{array}{l}49 \text { CFR } 173 \text { (latest revision) (Included in } 49 \text { CFR 100-199?) } \\
\text { [9] }\end{array}$ & $\begin{array}{l}\text { Still } \\
\text { Current }\end{array}$ & Yes & No \\
\hline 49 CFR 397, Hazardous Materials Regulations (DOT) [3] & $\begin{array}{l}\text { Still } \\
\text { Current }\end{array}$ & No & No \\
\hline 49 CFR 425 (c) (latest revision) [9] & $\begin{array}{l}\text { Still } \\
\text { Current }\end{array}$ & No & No \\
\hline NRC, Regulatory Guide 3.35 [2] & $\begin{array}{l}\text { Still } \\
\text { Current }\end{array}$ & No & No \\
\hline ERDA 76-21, Nuclear Air-Cleaning Handbook $[4,5,11]$ & $\begin{array}{l}\text { Still } \\
\text { Current }\end{array}$ & No & No \\
\hline Privacy Act of 1974, Title 5, U. S. Code 552, et seq. [7] & $\begin{array}{l}\text { Still } \\
\text { Current }\end{array}$ & No & No \\
\hline \multicolumn{4}{|l|}{ National Codes, Standards \& Guides } \\
\hline National Fire Codes (NFPA) $[2,3,5,11]$ & $\begin{array}{l}\text { Still } \\
\text { Current }\end{array}$ & Yes & No \\
\hline National Electrical Code (NFPA 70$)[2,3,4,5,11]$ & $\begin{array}{l}\text { Still } \\
\text { Current }\end{array}$ & Yes & No \\
\hline Uniform Building Code (UBC) [2] & $\begin{array}{l}\text { Still } \\
\text { Current }\end{array}$ & Yes & No \\
\hline ASME Boiler and Pressure Vessel Code $[2,3]$ & $\begin{array}{l}\text { Still } \\
\text { Current }\end{array}$ & Yes & No \\
\hline AISC, Manual of Steel Construction [2] & $\begin{array}{l}\text { Still } \\
\text { Current }\end{array}$ & No & No \\
\hline ASHRAE Handbook $[2,11]$ & $\begin{array}{l}\text { Still } \\
\text { Current }\end{array}$ & No & No \\
\hline $\begin{array}{l}\text { ANSI Z88.2, Practices for Respiratory Protection, } 1980[3,8 \text {, } \\
\text { 11] }\end{array}$ & $\begin{array}{l}\text { Still } \\
\text { Current }\end{array}$ & Yes & No \\
\hline $\begin{array}{l}\text { ANSI/ANS 8.1, Nuclear Criticality Safety in Operations with } \\
\text { Fissionable Materials Outside Reactors }[3,6]\end{array}$ & $\begin{array}{l}\text { Still } \\
\text { Current }\end{array}$ & Np & No \\
\hline ANSI/ ANS 8.3-1986, Nuclear Criticality Safety $[3,4,5,6,11]$ & $\begin{array}{l}\text { Still } \\
\text { Current }\end{array}$ & No & No \\
\hline $\begin{array}{l}\text { ANS/ANS8.5, Use of Borosilicate-Glass Raschig Rings as a } \\
\text { Neutron Absorber in Solutions of Fissile Material, } 1986[3,6]\end{array}$ & $\begin{array}{l}\text { Still } \\
\text { Current }\end{array}$ & No & No \\
\hline $\begin{array}{l}\text { ANSI / ANS 8.7, Guide for Nuclear Criticality Safety in the } \\
\text { Storage of Fissile Material [6] }\end{array}$ & $\begin{array}{l}\text { Still } \\
\text { Current }\end{array}$ & No & No \\
\hline
\end{tabular}




\begin{tabular}{|c|c|c|c|}
\hline $\begin{array}{l}\text { ANSI/ANS 8.15, Nuclear Criticality Control of Special } \\
\text { Actinide Elements, } 1981[3,6]\end{array}$ & $\begin{array}{l}\text { Still } \\
\text { Current }\end{array}$ & No & No \\
\hline $\begin{array}{l}\text { ANSI/ANS 8.19, Administrative Practices for Nuclear } \\
\text { Criticality Safety, } 1984[3,6]\end{array}$ & $\begin{array}{l}\text { Still } \\
\text { Current }\end{array}$ & No & No \\
\hline ANSI/ANS 8.20, Nuclear Criticality Safety Training [6] & $\begin{array}{l}\text { Still } \\
\text { Current }\end{array}$ & Yes & No \\
\hline $\begin{array}{l}\text { ANSI/ANS } 8.22, \text { Nuclear Criticality Safety Based on Limiting } \\
\text { and Controlling Moderators }[3,6]\end{array}$ & $\begin{array}{l}\text { Still } \\
\text { Current }\end{array}$ & Yes & No \\
\hline $\begin{array}{l}\text { ANSI/ASME N509, Nuclear Power Plant Air Cleaning Units } \\
\text { and Components }[4,5]\end{array}$ & $\begin{array}{l}\text { Still } \\
\text { Current }\end{array}$ & Yes & No \\
\hline $\begin{array}{l}\text { ANSI/ASME NQA-1, Quality Assurance Program } \\
\text { Requirement for Nuclear Facilities [5] }\end{array}$ & $\begin{array}{l}\text { Still } \\
\text { Current }\end{array}$ & No & No \\
\hline ANSI B30, Crane Safety [3] & $\begin{array}{l}\text { Still } \\
\text { Current }\end{array}$ & No & No \\
\hline ANSI C2, National Electrical Safety Code, 1993 [3] & $\begin{array}{c}\text { Still } \\
\text { Current }\end{array}$ & No & No \\
\hline $\begin{array}{l}\text { ANSI C95.1, Safety Levels with Respect to Human Exposure to } \\
\text { Radio Frequency Electromagnetic Fields, } 300 \mathrm{kHz} \text { to } 100 \mathrm{GHz} \text {, } \\
1982 \text { [3] }\end{array}$ & $\begin{array}{l}\text { Still } \\
\text { Current }\end{array}$ & Yes & No \\
\hline $\begin{array}{l}\text { ANSI/IEEE 344, Recommended Practices for Seismic } \\
\text { Qualification of Class I Electrical Equipment for Nuclear Power } \\
\text { Generating Stations }[4,5]\end{array}$ & $\begin{array}{l}\text { Still } \\
\text { Current }\end{array}$ & No & No \\
\hline $\begin{array}{l}\text { ANSI/IEEE 488.1, IEEE Standard Digital Interface for } \\
\text { Programmable Instrumentation }[4,5]\end{array}$ & $\begin{array}{l}\text { Still } \\
\text { Current }\end{array}$ & No & No \\
\hline $\begin{array}{l}\text { ANSI/ISA S5.1, Instrumentation Symbols and Identification } \\
{[4,5]}\end{array}$ & $\begin{array}{l}\text { Still } \\
\text { Current }\end{array}$ & No & No \\
\hline $\begin{array}{l}\text { ANSI N 13.1-1969, Guide to Sampling Airborne Radioactive } \\
\text { Materials in Nuclear Facilities (1969) [7] }\end{array}$ & $\begin{array}{l}\text { Still } \\
\text { Current }\end{array}$ & Yes & No \\
\hline $\begin{array}{l}\text { ANSI N 13.5, Performance Specifications for Direct Reading and } \\
\text { Indirect Reading Pocket Dosimeters for X and Gamma Radiation, } \\
1972 \text { [3] }\end{array}$ & $\begin{array}{l}\text { Still } \\
\text { Current }\end{array}$ & No & No \\
\hline $\begin{array}{l}\text { ANSI N13.6-1966, Practice for Occupational Radiation } \\
\text { Exposure Records Systems (1972) [7] }\end{array}$ & $\begin{array}{l}\text { Still } \\
\text { Current }\end{array}$ & No & No \\
\hline $\begin{array}{l}\text { ANSI N 42.18, Specifications and Performance of Onsite } \\
\text { Instrumentation for Continuously Monitoring Radioactivity in } \\
\text { Effluents, } 1978 \text { [3] }\end{array}$ & $\begin{array}{l}\text { Still } \\
\text { Current }\end{array}$ & No & No \\
\hline $\begin{array}{l}\text { ANSI N 43.2, Radiation Safety for X-ray Diffraction and } \\
\text { Fluorescence Analysis Equipment, } 1977 \text { [3] }\end{array}$ & $\begin{array}{l}\text { Still } \\
\text { Current }\end{array}$ & No & No \\
\hline $\begin{array}{l}\text { ANSI N 317, Performance Criteria for Instrumentation Used for } \\
\text { Implant Plutonium Monitoring, } 1980 \text { [3] }\end{array}$ & $\begin{array}{l}\text { Still } \\
\text { Current }\end{array}$ & No & No \\
\hline $\begin{array}{l}\text { ANSI N 319, Personnel Neutron Dosimeters (Neutron Energies } \\
\text { Less Than } 20 \mathrm{MeV} \text { ), } 1976 \text { [3] }\end{array}$ & $\begin{array}{l}\text { Still } \\
\text { Current }\end{array}$ & No & No \\
\hline $\begin{array}{l}\text { ANSI N 322, Inspection and Test Specifications for Direct and } \\
\text { Indirect Reading Quartz Fiber Pocket Dosimeters, } 1975[3,7]\end{array}$ & $\begin{array}{c}\text { Still } \\
\text { Current }\end{array}$ & No & No \\
\hline $\begin{array}{l}\text { ANSI N 323, Radiation Protection Instrumentation Test and } \\
\text { Calibration, } 1978[3,7]\end{array}$ & $\begin{array}{c}\text { Still } \\
\text { Current }\end{array}$ & No & No \\
\hline $\begin{array}{l}\text { ANSI N 543, General Safety Standard for Installations Using } \\
\text { Non-medical X-ray and Sealed Gamma-Ray Sources, } 1974 \text { [3] }\end{array}$ & $\begin{array}{c}\text { Still } \\
\text { Current }\end{array}$ & No & No \\
\hline $\begin{array}{l}\text { ANSI Y14.1, Engineering Drawing and Related Documentation } \\
\text { Practices }[4,5]\end{array}$ & $\begin{array}{l}\text { Still } \\
\text { Current }\end{array}$ & No & No \\
\hline
\end{tabular}


Appendix A: B332 ISMS

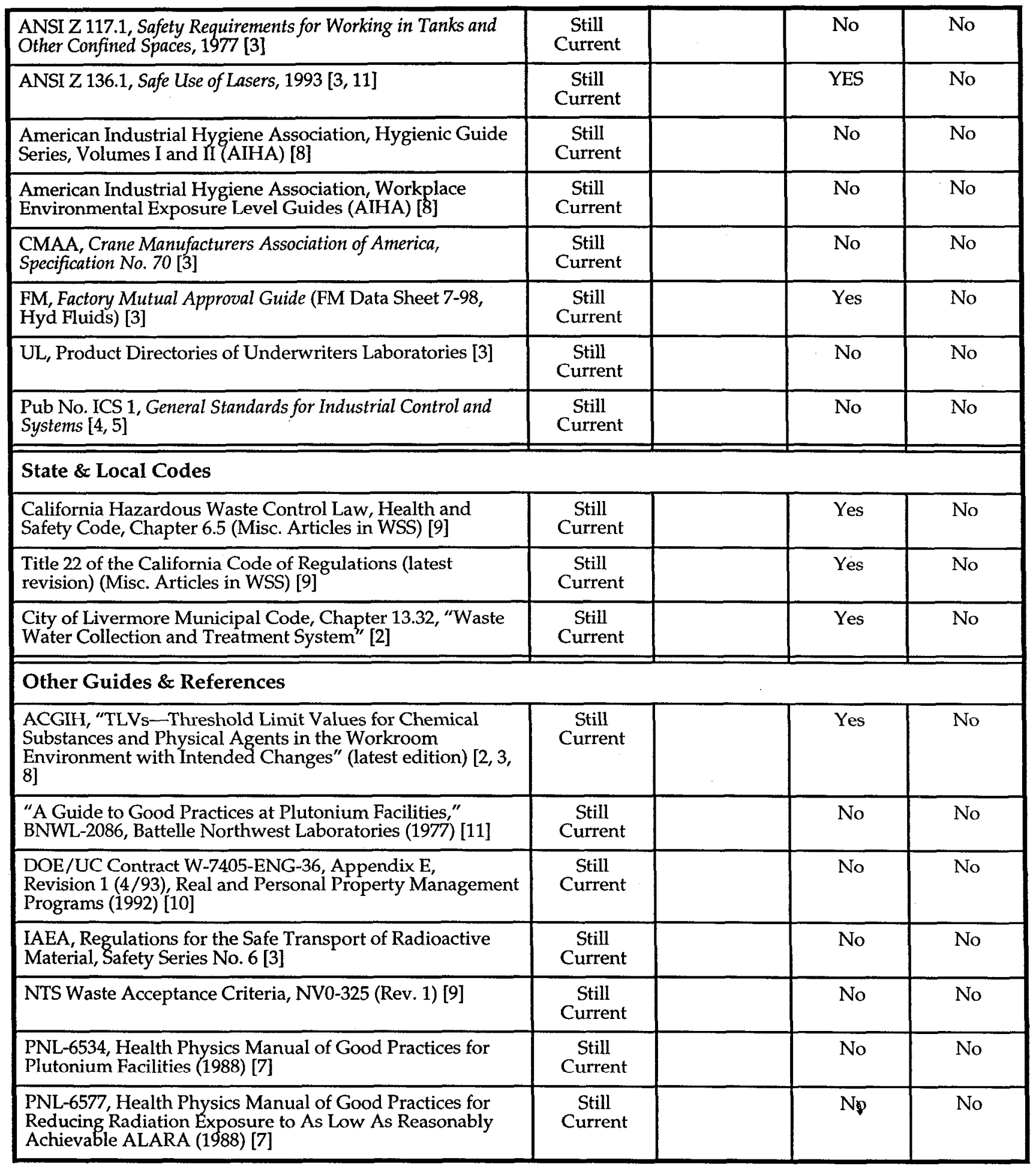


This page intentionally left blank. 


\section{APPENDIX B}

\section{Integrated Safety Management System (ISMS) \\ for \\ Building 331}

October 1999

Rev. 2 


\section{About This Appendix}

Sections 1.0 through 5.0, 8.0,12.0, and 13.0 of the Superblock Integrated Safety Management System Description, of which this appendix forms a part, covers the topics of those sections sufficiently for B331 as to make their further inclusion in this appendix redundant. This appendix, then, is composed of Sections 6.0,7.0, 9.0, 10.0, 11.0, and 14.0, corresponding to those sections of the main document but providing details specific to B331. It also includes Attachment A, Tritium Facility Work Smart Standards Reconciliation, which provides a comparison between those that are derived from the B331 SAR and the LLNL Work Smart Standards per the UC/DOE Contract Appendix G.

This document is to be used concurrently with the LLNL ISM System Description (Version 2.0, dated October 1, 1999), and the Work Smart Standards (from Contract 48 Appendix G). The Facility's Orders and Standards per the current Authorization Agreement and Work Smart Standards set as stated herein will match the institutional set with the issuance of the institution's associated implementing manuals and guidance after the reconciliation process. 


\section{TABLE OF CONTENTS}

6.0 Safety Management System Mechanisms ……………................................................ B-5

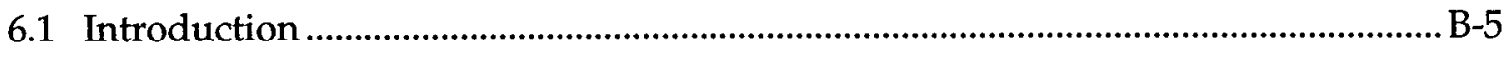

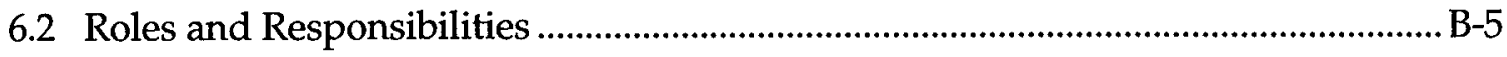

6.2.1 Line Management Responsibility for Safety ………................................... B-6

6.2.2 Clear Roles and Responsibilities............................................................ B-6

6.2.3 Competence Commensurate with Responsibilities ........................................ B-8

6.3 Work Planning and Prioritization ......................................................................... B-8

6.3.1 Define the Scope of Work......................................................................... B-8

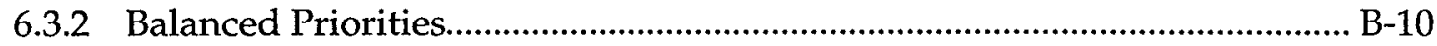

6.4 Hazards Analysis........................................................................................ B-10

6.4.1 Identify and Analyze Hazards ................................................................ B-11

6.4.2 Categorize Hazards .................................................................................... B-11

6.5 Hazard Mitigation and Control ............................................................................ B-12

6.5.1 Develop and Implement Hazard Controls ................................................. B-12

6.5.2 Identification of Safety Standards and Requirements .................................. B-13

6.5.3 Hazard Controls Tailored to Work Being Performed..................................... B-13

6.6 Work Authorization and Execution ................................................................... B-14

6.6.1 Confirm Readiness ................................................................................. B-14

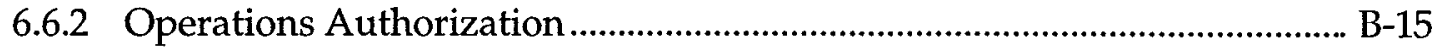

6.6.3 Perform Work Safely............................................................................ B-15

6.6.4 Performance Measures ......................................................................... B-15

6.7 Performance Monitoring and Improvement....................................................... B-16

6.7.1 Collect Feedback Information ……….......................................................... B-16

6.7.2 Identify Improvement Opportunities and Make Changes to Improve...... B-17

6.7.3 Oversight and Enforcement....................................................................... B-17

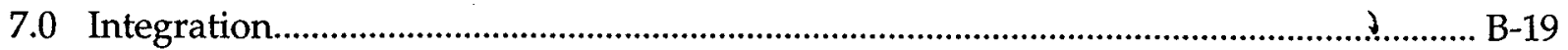

9.0 Standards and Requirements................................................................................ B-23

10.0 Evaluating and Resolving Non-Compliances ……..................................................... B-25

11.0 Flowdown of Requirements ............................................................................... B-27

14.0 Implementation Tasks, Schedule, and Milestones ...................................................... B-31

Attachment A Tritium Facility Work Smart Standards Reconciliation ................................. B-33 
This page intentionally left blank. 


\subsection{SAFETY MANAGEMENT SYSTEM MECHANISMS}

\subsection{Introduction}

This appendix-prepared by the Tritium Facility-Building 331 (B331) -is consistent with the Superblock Integrated Safety Management System (ISMS) Description and provides further specific details at the facility level and activity level. This section describes the mechanisms in place to implement an ISMS in B331, within LLNL's Superblock.

The LLNL Tritium Facility operates under the authority of an Authorization Agreement (AA) between LLNL's Associate Director for Defense \& Nuclear Technologies (AD/DNT) and the DOE Oakland Operations Manager, signed January 28, 1999. As a Nuclear Hazard Category 3 facility, B331 requires a less rigorous and detailed safety description than, for example, Building 332, a Category 2 facility. The B331 safety documents include the following:

- At the institutional level, the LLNL Environmental, Safety and Health Manual (ES\&HM).

- At the facility level, the Tritium Facility-B331 Facility Safety Plan (FSP), the B331 Safety Analysis Report (SAR), and the B331 Technical Safety Requirements (TSR).

- At the activity level, the FSP, Operational Safety Plans (OSPs), the Radiological Work Permits (RWPs), and the Hazard Assessment and Control Forms (HACs).

The ES\&HM establishes general ES\&H requirements. The SAR, the TSR, and the FSP establish specific safety basis and safety controls for the facility. The OSPs, RWPs, and HACs assess the responsibilities, hazards, and controls for each operation at the activity level. These safety practices at various levels are integrated to form the ISMS.

As described in Section 7.2 of the Superblock Integrated Safety Management System Description, the five core functions of the ISMS are implemented at all levels: from the Superblock level, to the facility level, to the activity level. The key information, processes, and requirements associated with the implementation of each core function at these three levels are depicted in Figure 4 in Section 7.2 of the main body of this Description. It should be emphasized that workers' participation at the activity level is the key to the successful implementation of the ISMS.

A matrix portraying a crosswalk of the programs, systems, and procedures in place to meet ISMS functions and principles in B331 is provided in Section 7.0, Integration.

\subsection{Roles and Responsibilities}

Line Management Responsibility for Safety (Guiding Principle 1)

Clear Roles and Responsibilities (Guiding Principle 2)

Competence Commensurate with Responsibility (Guiding Principle 3) 


\subsubsection{Line Management Responsibility for Safety}

B331 is managed by a Facility Manager (FM) with the support of a Facility Staff. The Facility Manager is also the Tritium Program Manager (PM) in the facility. Therefore, throughout this Appendix, reference to line management and roles and responsibilities in the Tritium Facility specify only the FM for both facility and programmatic responsibilities. The organization chart for B331 is shown in Figure 1. The AD/DNT, through the Nuclear Materials Technology (NMT) Program Leader and his deputies for Programs and Facility Operations, has delegated to the B331 FM the authority for, and holds the FM responsible for, operating the Facility and ensuring that the Facility meets Laboratory Environmental, Safety and Health (ES\&H) requirements. The LLNL ES\&HM, Volume I, Part 2, discusses the general ES\&H responsibilitics for an FM. The specific ES\&H responsibilities for the B331 FM are detailed in Section 2 of the FSP, the Nuclear Materials Technology Program Management Plan, and in Chapter 17 of the SAR. These responsibilities are briefly summarized as follows:

- Ensure that all activities in the facility are conducted safely.

- Maintain a current Emergency Response Plan and conduct training exercises as required in the Plan.

- Ensure that the Training Implementation Matrix/Training Program (TIM/TP) is implemented for facility workers.

- Ensure that facility ES\&H documents such as the SAR, TSR, FSP, and OSPs are reviewed on a timely basis to maintain them in current status.

- Implement the Quality Assurance program.

- Establish systems to ensure continuous feedback and improvement based on lessons learned.

- Require that personnel conform to the facility's TIM through constant assessment by the NMTP Training Manager that the required training is current.

\subsubsection{Clear Roles and Responsibilities}

The general roles and responsibilities related to safety of personnel working in B331 are delineated in the ES\&HM, Volume I, Part 2. The B331-specific details (including the Deputy FM, the Facility Coordinator, supervisors, and workers) are described in Section 2 of the FSP and Section 17.3.2.1 of the SAR. The responsibilities of all persons, including LLNL employees, contractor employees, and visitors (where appropriate), in B331 are briefly summarized as follows:

- Obtaining FM's review. Prior to beginning a new operation, the individual must obtain a review by the FM to determine if the activity is within the Facility's authorization basis and the FM's approval to proceed with activities after he/she has determined they are acceptable. This is accomplished through the use of the Facility's USQ Determination process.

- Participating in required training.

- Taking all reasonable precautions to prevent exposure to, or release of, radioactive and hazardous materials, and to prevent damage or loss of property. 
- Immediately reporting any injuries, incidents, and occurrences to their supervisor, Hazards Control Department, or the FM.

- Stopping work they believe cannot be done safely, per the ES\&HM, Volume I, Part 2. Correcting ES\&H-related problems immediately, or informing the supervisor or FM of the problem.

- Maintaining general housekeeping in the room they use, and the proper maintenance of the equipment they use.

- Conducting facility and programmatic activities in accordance with and within the controls of approved plans.

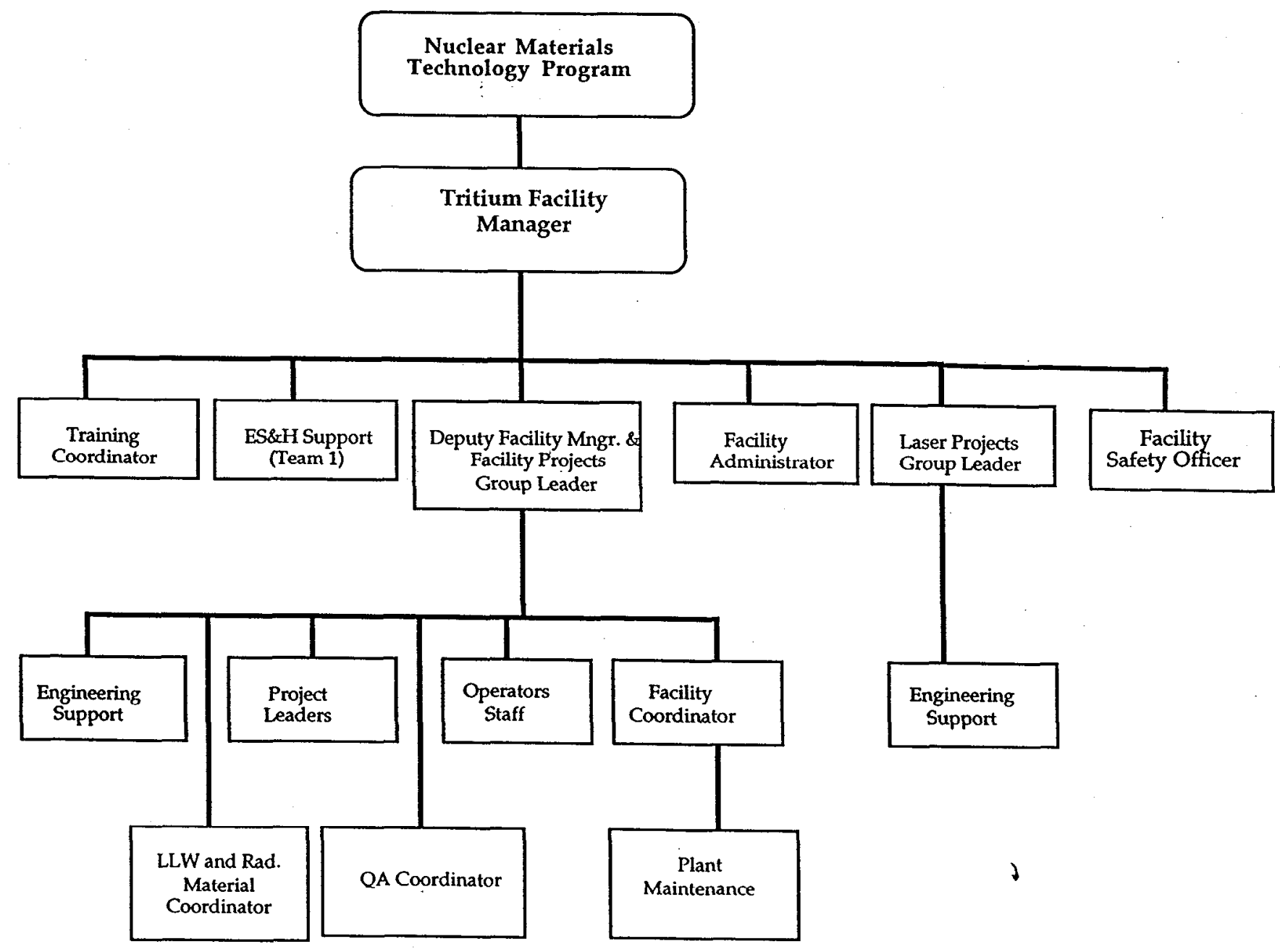

Figure 1. Tritium Facility-B331 Organization Chart. 


\title{
6.2.3 Competence Commensurate with Responsibilities
}

Programs to establish and maintain competency for B331 personnel are prescribed in the ES\&HM, Volume 5, Part 1, "Personnel," and are described in the SAR (particularly in Section 12.4) and the FSP, Section 5. Facility-specific training and qualification requirements for B331 personnel are specified in the DOE-approved B331 Training Implementation Matrix (TIM) and in the B331 Training Manual. Specific training requirements at the activity level are described in the training section of the OSP for a given activity or operation. Course requirements for Radioactive Materials Area (RMA) workers can be found on the Superblock Server (available to B331 staff), and are updated as requirements change. Training requirements may be established by payroll, facility, and program organizations. Payroll organizations establish general requirements, such as basic competency and general safety courses. The Facility establishes Facility-specific training requirements, such as safely handling radioactive gases, on-the-job training, and training on Facility-specific safety documents such as its SAR, FSP, etc. The program may establish training requirements necessary to meet programmatic or research and development needs as part of an OSP. The Facility also assists program users in developing and reviewing OSP, RWP, and HAC training at the activity level. All workers regularly doing tritium work in the RMA must be fluent in their safety responsibilities and the Facility's safety basis documents, including the FSP. All personnel requiring routine, unescorted access to the RMA (such as tritium workers, electrical technicians, etc.) must view the Facility Safety Video and pass a written test. The FM is responsible for ensuring and documenting that all personnel have completed the required training before work is performed in B331. The LLNL's Livermore Training Records and Information Network (LTRAIN) program and the NMTP Training Office monitor the training required for and accomplished by B331 employees.

Worker participation in safety planning and implementation is ensured through a number of mechanisms, including FSP briefings, pre-job planning, etc., which invite input from workers at all levels.

\subsection{Work Planning and Prioritization}

\author{
Define the Scope of Work (Core Function 1) \\ Balanced Priorities (Guiding Principle 4)
}

\subsubsection{Define the Scope of Work}

The Tritium Facility's mission is to provide a state-of-the-art, Category 3 nuclear facility with tritium research and development capability, focusing in the near term on tritium system design and tritium recovery and decontamination projects, and serving to maintain and nurture LLNL tritium expertise. The Facility will support low-inventory tritium operations and host compatible non-tritium activities.

Currently, B331 supports the mission by the following work activities:

- Designing, building, and operating tritium-handling systems supporting various DOE and DoD projects. 
- Conducting tritium-related research and development (R\&D) in support of surplus facility decontamination and decommissioning (D\&D), stockpile stewardship, and tritium supply.

- Recovering and recycling "waste" tritium.

- Assessing and repackaging tritiated legacy waste.

In translating the mission into work activities, ES\&H considerations are of top priority so that the mission is safely accomplished while protecting the public, the workers, and the environment. All work performed in B331 must be contained within the safety envelope approved by DOE/OAK as defined in the B331 SAR and TSR documents. These documents and the DOE Safety Evaluation Report, as documented in the Authorization Agreement (AA) approved January 28, 1999, establish the DOE safety authorization basis. The AA between the Associate Director for DNT and DOE/OAK establishes and defines authorized operations. Specific operations and controls encompassed by the SAR and the TSR, respectively, are further described by the FSP at the facility level and the OSPS at the activity level. The FSP and the OSPs define the controls applicable for operations based upon the hazards assessment. A B331 Work Control/Design Change Control Manual (Work Control Manual or WCM) provides directions on the Facility's procedures for new work and work controls. The FM is the first contact for programmatic representatives desiring to use any part of the Facility. The primary mechanism in the WCM that creates and implements the ISMS is the five-step process described in Section 2.0. The WCM takes into account all work in the Facility, rated from Category A through Category $C$, on the basis of their potential hazards and level of complexity. Formal approvals by the FM or his designee are required throughout the process. The WCM includes requirements for Unreviewed Safety Question (USQ) determinations to ensure the activities remain within the terms of the $A A$.

It should be noted that work performed in B331 includes both programmatic activities and Facility-related maintenance work. Maintenance activities in B331 are performed for the purpose of ensuring reliable operations and maintaining the safety envelope and consist of a balance of both corrective and preventive work. As described in the ES\&HM, Volume I, Part 2, and LLNL's Maintenance Implementation Plan (MIP) of March 1995, B331 implements the MIP and executes a maintenance planning cycle for all Facility equipment. This includes equipment that directly supports programmatic work. The five identifiable phases in the planning cycle are: conception, design/plan, production/procurement, operation, and termination/disposal. For Facility operations equipment, these processes are inherent within the building, while others may involve extensive interface with other program personnel.

At the facility level, Facility status meetings are held as needed, normally weekly. These meetings are attended by B331 personnel including workers, ES\&H Team 1 safety professionals, and invited guest experts. The meeting is chaired by the FM or designee, and the following items are generally discussed in the meeting:

- Facility status and review of safety awareness items.

- Review of work performed during the past week(s) and schedule of work to be performed in the coming week(s). Topics include work status, safety issues, special needs, and others.

- Review of facility trends, such as environmental effluents, personnel exposures, and contamination control. 
- Feedback and comments from attending staff.

- Other items, such as personnel assignment, lessons learned, etc.

At the activity level, for both programmatic and Facility maintenance activities, the work planning process in the WCM requires the responsible individual (RI) (in many cases, the RI is the worker who performs the work) to critically evaluate ES\&H issues in consultation with the FM by using the process described in the ES\&HM, Volume I, Part 2, and the WCM. In this process, the RI may use the services of the ES\&H specialists available in LLNL's ES\&H Team 1 in preparing the OSP, RWP, and HAC. The resulting ES\&H evaluation is submitted to the FM for approval. The FM may authorize the activity if it is within the authorization basis and conforms with existing Facility plans (FSP or OSPs, existing permits, etc.). The FM also may direct the preparation of additional safety analyses, changes to the FSP, OSPs, RWPs, operating plans, or other documentation, including USQ documentation. The FM may require the RI to present the activity to a Design Review Committee for further analysis by Facility management and technical and ES\&H Team 1 safety experts, as required to give appropriate consideration to safety needs. Additional detail describing thresholds for various types of authorizations and approvals is in the WCM.

\subsubsection{Balanced Priorities}

B331 complies with the LLNL policy to perform work in a manner that protects the health and safety of employees and the public, preserves the quality of the environment, and prevents property damage. ES\&H matters are priority considerations in the planning and execution of all work. Safe methods will be established by the FM with the assistance of the ES\&H Team 1 for the work to be accomplished according to the needs of the programs or the FM will not authorize the activity to commence. The WCM establishes the standards for review for operations and activities to ensure safety and environmental protection prior to authorization, and all Facility personnel know that unauthorized work will not be done.

Funding for operations and maintenance in B331 relies on two basic sources: DNT programmatic funding and "user fees" from other programmatic projects. DNT funding is determined by the AD/DNT based upon annual budget plans provided by the NMT Program Leader. User fees are assessed on the basis of contract size for facility services and facility space use. Requests for additional funding (e.g., for emergency use) are considered on a case-by-case basis and provided according to justification and needs by the NMT Program Leader, programmatic managers, and the AD/DNT. Emergency facility maintenance requirements would be provided by the AD/DNT through the NMT Program Leader.

Before each fiscal year, the FM submits a work plan to the NMT Program Leader listing prioritized improvements above the minimum estimate to maintain B331 and proyide support and services to the users. Included in the services provided to the facility is the funding of ES\&H Team 1 for the Tritium Facility activities as documented in the B331 ES\&H Team Action Plan. The priorities are agreed upon and approved depending on the amount of additional funding actually realized through the year.

\subsection{Hazards Analysis}

Analyze the Hazards (Core Function 2) 


\subsubsection{Identify and Analyze Hazards}

All activities conducted in B331 require a critical evaluation of the hazards prior to conducting work. The determination of the hazards analysis techniques to be used and the rigor to be applied is based on the hazards identified with the work to be performed. The B331 Safety Analysis Report (SAR) identifies and analyzes the hazards for the building. The SAR's hazard analysis is the most rigorous and completely documented determination of hazards and risks to Facility workers, the public, and the environment. SAR hazards analyses are performed by Subject Matter Experts (SMEs) in concert with Facility personnel and workers acquainted with operations and activities, using "failure mode and effects analysis" in accordance with DOE STD 3009 and DOE Order 5480.23. New proposed activity and equipment installation, major changes to existing activities, and major equipment modifications must go through a formal USQ process for hazard analyses as described in Appendix G of the FSP. Hazard analyses described in Section 4 of the B331 FSP include the following:

- Chemicals.

- Cryogens.

- Electrical.

- Fire.

- Earthquakes.

- Material handling.

- Pressure.

- Ionizing radiation, including tritium as a gas or in tritiated materials.

This list provides general bounds for the variety of hazardous operations that are performed in $\mathrm{B} 331$ and that have been the basis for establishing the SAR bases. This variety requires a flexible, or graded, approach in analyzing the hazards to establish controls to achieve an acceptable level of risk. At the activity level, the RI (in many cases, the RI is the worker who performs the work), working with the FM and supplemented as needed by ES\&H Team 1 SMEs, determines at what levels an evaluation shall be performed per the WCM. The evaluation also takes into consideration the lessons learned from previous B331 experiences and from other facilities, including those outside LLNL. The resulting hazards are described in the OSPs and summarized in the Radiological Work Permits (RWPs) or the Hazard Assessment Control Forms (HACs) for Category B or C work as required by the WCM.

Based upon identified hazards, the FSP (Section 4) defines the process for which operations will be authorized and under what controls. Beyond those bounds, additional reviews and analyses are required, resulting in defined safety controls that must be met to be consistent with the SAR and TSR.

\subsubsection{Categorize Hazards}

Building 331 is categorized as a Nuclear Hazard Category 3 nonreactor nuclear facility using the methodology set forth in DOE-STD-1027-92 and as determined in the DOE-approved SAR. 
Non-nuclear hazards within B331 are further categorized to be low (under DOE Order 5481.1B) as stated in the B331 SAR.

Activities in B331 are assessed routinely during the planning phases of an activity as prescribed in the WCM. As the planning of the activity progresses, the following steps are prescribed:

(1) Identify the safety and health hazards and the environmental concerns of the activity (conducted by all participants, including workers).

(2) Evaluate the risk of conducting the operation within the Facility's authorization basis per the Facility's Unreviewed Safety Questions (USQ) process.

(3) Identify the controls necessary to conduct the operations safely and in compliance with accepted standards and regulations.

(4) Identify and prepare documents necessary to conduct the operation and implement the controls. These documents may include OSPs, operating procedures, permits, or other documentation such as decontamination and disposition plans, and Quality Assurance plans.

A comprehensive system to tailor the controls as an enhancement to the ES\&HM, Volume I, Part 2, is in development, called the "CHOOSE" (Controls/Hazards Operations-Oriented Safety Envelope) database. It describes a technique to use a graded approach for achieving an acceptable level of risk. The graded approach identifies the level of effort that would be cost effective or commensurate with the hazards involved.

\title{
6.5 Hazard Mitigation and Control
}

\author{
Develop and Implement Hazard Controls (Core Function 3) \\ Identification of Safety Standards and Requirements (Guiding Principle 5) \\ Hazard Controls Tailored to Work Being Performed (Guiding Principle 6)
}

\subsubsection{Develop and Implement Hazard Controls}

The B331 SAR was prepared and is reviewed annually by the FM with assistance from staff, workers, and appropriate safety experts. It provides the basis for hazard and accident analyses that are used to develop controls for preventing or mitigating hazard events. These controls include engineered controls (structures, systems, and components) and administrative controls. As described in the SAR, B331 does not present an exposure risk to off-site personnel; therefore, there are no safety-class structures, systems, and components (SSCs) in B331. Gloveboxes are the only safety-significant SSCs in B331; these are judged necessary for the protection of Facility workers and collocated workers. Derivations of detailed Technical Safety Requirements (TSRs) are described in Chapter 5 of the SAR and documented in the B331 Technical Safety Requirements (UCRL-AR-132403). The specific TSRs for B331 appear in Table 5.2 of the TSR and consist exclusively of administrative controls that set the inventory limits and ensure that gloveboxes are operable. Other engineering safety features and administrative safety programs (including safety plans) are also discussed in the SAR in Chapter 3 and Chapters 7 through 17 and in the TSR. These features and programs provide defense-in-depth, ensure that TSRs are enforced, and relate to management, training, reviews and audits, quality assurance, and others to ensure 
safe operation of B331. The B331 FSP specifies operating practices, access controls and requirements, and general building rules.

The FM is the key person responsible for seeing that the workers implement the B331 hazard controls.

At the facility and activity levels, specific hazard controls applied to activities in B331 are assessed and developed routinely during the planning phases of an activity as prescribed in the ES\&HM, Volume I, Part 2. As the planning of the activity progresses, the following steps are prescribed:

- An evaluation to identify the safety and health hazards and the environmental concerns of the activity is conducted by all participants, including workers.

- The controls necessary to conduct the operations safely and in compliance with accepted standards and regulations are identified:

- Documents necessary to conduct the operation and implement the controls are identified and prepared. These documents may include OSPs, operating plans, permits, or other documentation.

A graded approach is used in B331 to develop the controls as suggested in the ES\&HM, Volume I, Part 2. The graded approach identifies the level of effort that would be cost effective and commensurate with the hazards involved.

To further protect the public, employees, and property, B331 has a formalized emergency preparedness program, described in the Self-Help Plan for Zone 8 Superblock (UCRL-AR-135652), in Chapter 15 of the SAR, and in Section 7 of the FSP.

\subsubsection{Identification of Safety Standards and Requirements}

B331 operation conforms to all applicable laws, statutes, Federal rules, and DOE directives; uses DOE guides and technical standards; and provides for DOE/OAK review and concurrence. The current safety-related administrative and reporting requirements are specified in the DOEapproved B331 AA and the Facility's SAR and TSR documents. Attachment A to this Appendix is a current reconciliation between the Authorization Basis Standards and Orders and the WSS. It identifies those areas where changes in the Authorization Basis will be required.

\subsubsection{Hazard Controls Tailored to Work Being Performed}

The Facility has established three levels of controls for programmatic operations - the FSP, the OSPs, and the Radiological Work Permits (RWPs) or the Hazard Assessment and Control Forms (HACs). These three levels of controls, the requirements for which are detailed in the WCM, are all tailored to the work performed in B331.

The FSP at the facility level implements the TSRs and safety programs of the SAR, describes the ES\&H controls, and specifies operating practices, access controls, and general building rules. The FSP applies to all facility-standard practices and for long-term activities and, per the ES\&HM, Volume I, Part 4, is valid for a maximum of three years. It may be revised more often if deemed necessary. B331 has also initiated an effort to systematically evaluate the importance 
of Human Factors Engineering in facility and programmatic operations. This program has been established to enhance facility safety and is documented within the SAR. It encompasses design, operations, training, documentation, staff, management, hazards, health, safety, and quality control.

Again per the ES\&HM, Volume I, Part 4, OSPs, at the activity level, describe controls for individual, limited-term activities and are valid for a maximum of one year. They will be revised or supplemented more often if activities change. Also at the activity level, the RWP considers radiological and industrial hazards, and the HAC addresses chemical and physical hazards. These permits document the hazards, job monitoring requirements, and operational controls associated with the job. The work permit system is described in Appendix I of the FSP. It should be noted that the OSPs, RWPS, and HACs are prepared by the responsible individual (RI) of the activity (in many cases, the RI is the worker who performs the work), working with the FM and supplemented as needed by ES\&H Team 1.

In addition, LLNL work permits are required for welding, burning, or other hazardous operations (see the ES\&HM, Volume II, Part 10). A B331 Work Control Package is required for specific facility and programmatic maintenance and operations to ensure that potential hazards are identified and necessary precautions are in place before beginning work in the Facility.

\subsection{Work Authorization and Execution}

Perform Work within Controls (Core Function 4)

Operations Authorization (Guiding Principle 7)

\subsubsection{Confirm Readiness}

After verifying that work is within the AA safety envelope, the B331 FM is responsible for ensuring that it complies with the requirements of the ES\&HM, Volume I, Part 2, for conducting pre-start and readiness reviews, and Volume V, Part 5, for startup and restart of facility and programmatic activities and readiness of new or revised operations. The formality and rigor of the review follow a graded approach depending on the complexity and potential hazards involved but will at a minimum be documented by an approved work permit. Prestart reviews ensure that:

- Hardware and tools are available, the facility is operable, and the equipment is tested.

- The required safety systems are correctly installed and tested and the appropriate personnel are trained in the use of these systems.

- The activities and/or experiments are ready, plans are complete, maintenance of safety systems is scheduled, ES\&H documentation is complete, and permits are issued as required.

- Personnel know their responsibilities and are trained or certified as required for the operations.

All work is subjected to the USQ process to verify that it is within the AA safety envelope. 
The WCM provides step-by-step directions for gaining authorization to proceed in Section 2.0. Personnel performing the work have been trained in the requirements, and the FM has additional cognizant staff to assist in preventing unauthorized work from occurring. Key documents for authorization include the Work Request/Feedback Form (WRFF), Radiological Work Permit (RWP), and Hazard Assessment and Control Form (HAC). These forms, using a graded approach, plus the weekly facility status meetings and pre-job briefings, keep the FM apprised of activities and provide opportunities for halting the work before it starts if deemed advisable.

\subsubsection{Operations Authorization}

Within the terms of the AA, detailed in the SAR and TSR, the FSP is approved by the AD/DNT, authorizing the stated activities. Each OSP (level B), RWP, or HAC is approved by the FM to indicate authorized work and activities. The work control process for all other work is described in the WCM and Sections 3 and 4 and Appendix I of the FSP.

\subsubsection{Perform Work Safely}

Safety requirements are incorporated into the FSP, OSPs, RWPs, and HACs as required. These documents implement a broad range of guidance and requirements from the ES\&HM for both facility operations and job-specific tasks. B331 has implemented the requirements of the ES\&HM, Volume I, Part 2. Facility maintenance is conducted in accordance with an approved LLNL Maintenance Implementation Plan (MIP). The WCM defines procedures to control work activities. It provides requirements for management and workers for the use of procedures, including detailed checklists, outlines of tasks, and skill of the craft when no written procedure is required. As stated in Section 6.2.2, above, workers understand under LLNL and Facility procedures that they have the right and responsibility to stop potentially unsafe work and report unsafe situations.

The B331 Work Authorization process ensures that the proposed work has received an adequate level of review, that appropriate detail in plans is available, and that personal protective equipment, contamination, and operational safety controls have been reviewed and agreed

upon by management and workers and are adequate for the proposed work. The Work Authorization process is described in greater detail in the WCM. Section 2 details the first four steps of the five-step process required to accomplish work in B331 (the fifth step regards providing feedback after the job is completed).

At the activity level, the key factor to performing work safely is the safety awareness and training/qualification of the workers. Section 6.2.3 of this Appendix provides a detailed description of workers' training. A pre-job briefing, including the review of the ASP, RWP, or $\mathrm{HAC}$, is conducted to address the safety concerns of the proposed work.

\subsubsection{Performance Measures}

Consistent with Section 6.7.1.3 of the LLNL ISMS Description and Section 6.6.4 of the Superblock ISMS Description, Building 331 will contribute to the institutional performance objectives, criteria, and measures (POCMs). Seven specific areas have been identified as relating to the Contract 48 Appendix F performance measures: 
- Implementing the five core functions of Integrated Safety Management based on this ISMS Description (App. F, Part II-2, Criteria 1.4).

- Maintaining zero toxic material and physical agent exposure (App. F, Part I-2, Criteria 1.4.d).

- Maintaining zero incidence of environmental regulatory violations and releases (App. F, Part II-2, Criteria 1.4.h).

- Setting and maintaining ALARA goals for the facility workers (App. F, Part II-2, Criteria 1.4.a).

- Reducing standard occupational safety and health injury and illness rates to a level that is at or below the mean rate for the DOE complex. We propose to accomplish this by raising worker consciousness through improved communication of accident- and injuryprevention strategies (App. F, Part II-2, Criteria 1.4.e).

- Reducing the generation of low-level, mixed, and hazardous wastes to meet DOE's stated pollution-prevention goals for the year (App. F, Part II-2, Criteria 1.4.g).

- Reducing safety-related occurrences, also through raising worker consciousness, similarly to the occupational injury and illness item above.

The annual institutional performance assessment by the Laboratory, University of California, and DOE/OAK will reflect the contributions of Building 331 to the Laboratory's overall performance in accordance with Contract 48.

\subsection{Performance Monitoring and Improvement}

Provide Feedback and Continuous Improvement (Core Function 5)

\subsubsection{Collect Feedback Information}

B331 fully utilizes the Superblock established feedback process (see Superblock ISMS Description, Section 6.7.1) to collect feedback information, which includes:

- DNT ES\&H Self-Assessment Plan (DNT-SA.4), which includes the monitoring and tracking of corrective actions using the LLNL Deficiency Tracking (DefTrack) system.

- NMTP Feedback and Improvement Program (FIP), which includes systems for identifying deficiencies and providing lessons learned.

- Other internal assessments, such as Laboratory audits, LLNL Lessons Learned Program (e.g., HCD "Lessons Learned" newsletter), Occurrence Reports, and Incident Analysis Findings.

- External assessment, such as DOE and other agencies' audits, DNFSB trip reports, DOE Lessons Learned Program (e.g., DOE Operating Experience Weekly Summary), and others.

Furthermore, at the facility level, the B331 weekly facility status meeting, attended by B331 staff, collects general feedback from attendees, including supervisors and workers. Ideas for implementing areas for improvement are discussed and documented in meeting minutes. 
At the activity level, workers' feedback on operations is expected and encouraged at every opportunity. The Work Control Packages include a safety feedback section to collect feedback on safety issues from supervisors and workers. Corrective actions required for reportable occurrences are determined through formal Root Cause Analysis by the NMT Program Leader, with assistance from his deputies. Identification of potentially serious safety-related trends based on DefTrack data is included in the Annual ES\&H Report by the AD/DNT Assurance Manager. The FM determines the causes of those trends as they relate to activities in B331. Because of the relatively small number of building residents and workers, B331 personnel are also personally encouraged to provide feedback to the FM directly. Because of the importance placed by the AD/DNT, the NMT Program Leader, and the FM, included in the stop-work empowerment is the assurance that employees who use it will be heeded without question or restraint. The facility maintains an internal Corrective Action Request (CAR) system for documenting feedback and tracking closure. CAR items may include problems mentioned at the weekly facility status meeting. The NMTP FIP Master Action Database (MAD) consolidates and tracks to closure DefTrack deficiencies, CAR items, and any other concerns identified by the FM.

\subsubsection{Identify Improvement Opportunities and Make Changes to Improve}

As stated above, B331 uses DefTrack to track the status of ES\&H deficiencies resulting from assessments conducted per the DNT Self-Assessment Plan and from all formal internal and external assessments. Additionally, corrective actions resulting from occurrence reports, incident analysis findings, and Price-Anderson Amendments Act issues are entered and tracked through DefTrack per DNT policy. The DefTrack system is the primary tool for identifying trends, improvement opportunities and for tracking deficiencies to closure.

In addition, B331 maintains a facility Corrective Action Reporting (CAR) system that tracks the status and closures of all the ES\&H feedback such as: feedback collected from the weekly facility status meetings, information identified in the feedback section of the Work Control Package, and feedback from other sources. The facility CAR system also includes and tracks for closure those deficiencies and issues resulting from informal internal assessments and determined not to warrant entry into the DefTrack system. The facility CAR system provides an additional tool for identifying improvement opportunities and for tracking closure. NMTP policy also requires lesser concerns and commitments to be tracked in the MAD, which includes sorting capabilities to assist in identifying areas of concern on a macro basis (such as compliance effectiveness and ISMS implementation) as well as the micro basis typical of a database. The DefTrack, CAR, and MAD systems track and document deficiencies and feedback for closure when corrective actions are completed. These processes ensure that improvements will be made from information identified through assessment, feedback, lessons learned, and other sources. The FM is responsible for evaluating and implementing the improvements.

\subsubsection{Oversight and Enforcement}

Section 2 of the FSP defines the responsibility and authority of Facility Management with regard to oversight and enforcement. In general terms, for programmatic work, Facility Management provides oversight, and program line managers have enforcement responsibility. The Program Manager for tritium activities is the Facility Manager. The FM has the responsibility for assessing the adequacy of operations, equipment, and plans, while the line manager has the responsibility for making corrections to the FM's satisfaction. For the Facility operating systems 
and Facility-led programs, the FM has the responsibility for both oversight and enforcement of adequate operations, equipment, and plans. Additional oversight is provided at the next higher level by the NMT Program Leader, and by DOE/OAK through the continuous presence in the Facility of a resident Facility Representative. 


\subsection{INTEGRATION}

The integration of the functions and principles of ISMS in Building 331 are summarized in a matrix shown in Tables 1 through 5 . The documents listed establish and implement the Facility standards pertaining to the Core Functions and Guiding Principles.

The following abbreviations are used in Tables 1 through 5:

AA - Authorization Agreement

DNT Policy - ES\&H Policy for the DNT Directorate, AD letter dated 2/2/96

ES\&HM - LLNL ES\&H Manual

FDRC - Facility Design Review Committee

FIP - NMTP Feedback and Improvement Program

FSP - Facility Safety Plan

N/A - Not Applicable

OSP - Operational Safety Plan

SAP - DNT Self-Assessment Plan (DNT-SA.4)

SAR - Safety Analysis Report

SER - Safety Evaluation Report

TIM - Training Implementation Matrix

TSR - Technical Safety Requirement

WCM - Work Control Manual

WP - Work Permit, such as Radiological Work Permit (RWP) or Hazard Assessment and

Control Form (HAC)

Table 1. Define the Scope of Work (Core Function 1) Crosswalk.

\begin{tabular}{|c|c|c|c|c|c|c|}
\hline $\begin{array}{c}\text { Line } \\
\text { Management } \\
\text { Responsibility } \\
\text { for Safety }\end{array}$ & $\begin{array}{c}\text { Clear Roles } \\
\text { and } \\
\text { Responsibilities }\end{array}$ & $\begin{array}{c}\text { Competence } \\
\text { Commensurate } \\
\text { with } \\
\text { Responsibilities }\end{array}$ & $\begin{array}{l}\text { Balanced } \\
\text { Priorities }\end{array}$ & $\begin{array}{l}\text { Identification } \\
\text { of Safety } \\
\text { Standards } \\
\text { and } \\
\text { Requirements }\end{array}$ & $\begin{array}{l}\text { Hazard } \\
\text { Controls } \\
\text { Tailored } \\
\text { to Work } \\
\text { Being } \\
\text { Performed }\end{array}$ & $\begin{array}{l}\text { Operations } \\
\text { Authorization }\end{array}$ \\
\hline $\begin{array}{l}\text { - ES\&HM } \\
\text { Vol. I, Part } 2 \\
\text { - DNT Policy } \\
\text { - SAR, } \\
\text { Sect. } 17.3 .2 \\
\text { - FSP, Sect. } 2 \\
\text { - WCM }\end{array}$ & $\begin{array}{l}\text { - ES\&HM } \\
\text { Vol. I, Part } 2 \\
\text { - DNT Policy } \\
\text { - SAR, } \\
\text { Sect. } 17.3 .2 \\
\text { - FSP, Sect. } 2 \\
\text { - WCM }\end{array}$ & $\begin{array}{l}\text { - ES\&HM } \\
\text { Vol. I, Part 2, } \\
\text { and Vol. IV, } \\
\text { Part } 2 \\
\text { - SAR, Sect. } \\
\text { 12.4 } \\
\text { - FSP, Sect. } 5\end{array}$ & $\begin{array}{l}\text { - ES\&HM } \\
\text { Vol. I, } \\
\text { Part } 2 \\
\text { DNT } \\
\text { Policy } \\
\text { - WCM }\end{array}$ & $N / A$ & $\mathrm{~N} / \mathrm{A}$ & $\mathrm{N} / \mathrm{A}$ \\
\hline
\end{tabular}


Table 2. Analyze the Hazards (Core Function 2) Crosswalk.

\begin{tabular}{|c|c|c|c|c|c|c|}
\hline $\begin{array}{c}\text { Line } \\
\text { Management } \\
\text { Responsibility } \\
\text { for Safety }\end{array}$ & $\begin{array}{c}\text { Clear Roles } \\
\text { and } \\
\text { Responsibilities }\end{array}$ & $\begin{array}{c}\text { Competence } \\
\text { Commensurate } \\
\text { with } \\
\text { Responsibilities }\end{array}$ & $\begin{array}{l}\text { Balanced } \\
\text { Priorities }\end{array}$ & $\begin{array}{l}\text { Identification } \\
\text { of Safety } \\
\text { Standards } \\
\text { and } \\
\text { Requirements }\end{array}$ & $\begin{array}{c}\text { Hazard } \\
\text { Controls } \\
\text { Tailored } \\
\text { to Work } \\
\text { Being } \\
\text { Performed }\end{array}$ & $\begin{array}{l}\text { Operations } \\
\text { Authorization }\end{array}$ \\
\hline $\begin{array}{l}\text { - } \text { AA } \\
\text { - ES\&HM } \\
\text { Vol. I, Part } 2 \\
\text { - DNT Policy } \\
\text { - SAR, } \\
\text { Sect. 17.3.2 } \\
\text { - FSP, Sect. } 2 \\
\text { - OSPs } \\
\text { - WPs } \\
\text { - WCM }\end{array}$ & $\begin{array}{l}\text { - AA } \\
\text { - ES\&HM } \\
\text { Vol. I, Part 2, } \\
\text { and Vol. I, } \\
\text { Part 4 } \\
\text { - DNT Policy } \\
\text { - SAR, } \\
\text { Sect. 17.3.2 } \\
\text { - FSP, Sect. } 2 \\
\text { - OSPS } \\
\text { - WPs } \\
\text { - WCM }\end{array}$ & $\begin{array}{l}\text { - AA } \\
\text { - ES\&HM } \\
\text { Vol. I, Part 2, } \\
\text { and Vol. IV, } \\
\text { Part } 2 \\
\text { - SAR, Sect. } \\
12.4 \\
\text { - FSP, Sect. } 5\end{array}$ & N/A & N/A & N/A & N/A \\
\hline
\end{tabular}

Table 3. Develop and Implement Hazard Controls (Core Function 3) Crosswalk.

\begin{tabular}{|c|c|c|c|c|c|c|}
\hline $\begin{array}{c}\text { Line } \\
\text { Management } \\
\text { Responsibility } \\
\text { for Safety }\end{array}$ & $\begin{array}{c}\text { Clear Roles } \\
\text { and } \\
\text { Responsibilities }\end{array}$ & $\begin{array}{l}\text { Competence } \\
\text { Commensurate } \\
\text { with } \\
\text { Responsibilities }\end{array}$ & $\begin{array}{l}\text { Balanced } \\
\text { Priorities }\end{array}$ & $\begin{array}{l}\text { Identification } \\
\text { of Safety } \\
\text { Standards } \\
\text { and } \\
\text { Requirements }\end{array}$ & $\begin{array}{l}\text { Hazard } \\
\text { Controls } \\
\text { Tailored } \\
\text { to Work } \\
\text { Being } \\
\text { Performed }\end{array}$ & $\begin{array}{l}\text { Operations } \\
\text { Authorization }\end{array}$ \\
\hline $\begin{array}{l}\text { - AA } \\
\text { - ES\&HM } \\
\text { Vol. I, Part } 2 \\
\text { - DNT Policy } \\
\text { - SAR, } \\
\text { Sect. } 17.3 .2 \\
\text { - FSP, Sect. } 2 \\
\text { - OSPs } \\
\text { - WCM } \\
\text { - WPs }\end{array}$ & $\begin{array}{l}\text { - AA } \\
\text { - ES\&HM } \\
\text { Vol. I, Part 2, } \\
\text { and Vol. I, } \\
\text { Part 4 } \\
\text { - DNT Policy } \\
\text { - SAR, } \\
\text { Sect. } 17.3 .2 \\
\text { - FSP, Sect. } 2 \\
\text { - OSPs } \\
\text { - WCM } \\
\text { - WPs }\end{array}$ & $\begin{array}{l}\text { - ES\&HM } \\
\text { Vol. I, Part 2, } \\
\text { and Vol. I, } \\
\text { Part 4, and } \\
\text { Vol. V, Part } 1 \\
\text { - SAR, } \\
\text { Sect. } 12.4 \\
\text { - FSP, Sect. } 5 \\
\text { - TIM }\end{array}$ & $\mathrm{N} / \mathrm{A}$ & $\begin{array}{l}\text { - } \text { AA } \\
\text { - ES\&HM } \\
\text { Vol. I, } \\
\text { Part } 2 \\
\text { - SAR } \\
\text { - WCM }\end{array}$ & $\begin{array}{l}\text { - ES\&HM } \\
\text { Vol. I, } \\
\text { Part } 2 \\
\text { - SAR, } \\
\text { Chap. } 4 \\
\text { \& } 5 \\
\text { - TSR } \\
\text { - FSP, } \\
\text { Sect. } 3 \\
\text { \& } 4 \\
\text { - OSPs } \\
\text { - WCM } \\
\text { - WPs }\end{array}$ & $\mathrm{N} / \mathrm{A}$ \\
\hline
\end{tabular}

Table 4. Perform Work within Controls(Core Function 4) Crosswalk.

\begin{tabular}{|c|c|c|c|c|c|c|}
\hline $\begin{array}{c}\text { Line } \\
\text { Management } \\
\text { Responsibility } \\
\text { for Safety }\end{array}$ & $\begin{array}{l}\text { Clear Roles and } \\
\text { Responsibilities }\end{array}$ & $\begin{array}{c}\text { Competence } \\
\text { Commensurate } \\
\text { with } \\
\text { Responsibilities }\end{array}$ & $\begin{array}{l}\text { Balanced } \\
\text { Priorities }\end{array}$ & $\begin{array}{l}\text { Identification } \\
\text { of Safety } \\
\text { Standards } \\
\text { and } \\
\text { Requirements }\end{array}$ & $\begin{array}{l}\text { Hazard } \\
\text { Controls } \\
\text { Tailored } \\
\text { to Work } \\
\text { Being } \\
\text { Performed }\end{array}$ & $\begin{array}{l}\text { Operations } \\
\text { Authorization }\end{array}$ \\
\hline $\begin{array}{l}\text { - AA } \\
\text { - ES\&HM } \\
\text { Vol. I, Part } 2 \\
\text { - DNT Policy } \\
\text { - SAR, } \\
\text { Sect. } 17.3 .2 \\
\text { - FSP, Sect. } 2 \\
\text { - OSPs } \\
\text { - WCM } \\
\text { - WPs } \\
\end{array}$ & $\begin{array}{l}\text { - AA } \\
\text { - ES\&HM } \\
\text { Vol. I, Part } 2 \\
\text { - DNT Policy } \\
\text { - SAR, } \\
\text { Sect. } 17.3 .2 \\
\text { - FSP, Sect. } 2 \\
\text { - OSPs } \\
\text { - WPs }\end{array}$ & $\begin{array}{l}\text { - ES\&HM } \\
\text { Vol. I, Part 2, } \\
\text { and Vol. IV, } \\
\text { Part } 2 \\
\text { - SAR, } \\
\text { Sect. } 12.4 \\
\text { - FSP, Sect. } 5 \\
\text { - TIM }\end{array}$ & $\mathrm{N} / \mathrm{A}$ & $\mathrm{N} / \mathrm{A}$ & $\mathrm{N} / \mathrm{A}$ & $\begin{array}{l}\text { - AA } \\
\text { - ES\&HM } \\
\text { Vol. I, Part 2, } \\
\text { and Vol. V, } \\
\text { Part } 5 \\
\text { - OSPs } \\
\text { - WCM } \\
\text { - WPs }\end{array}$ \\
\hline
\end{tabular}


Table 5. Provide Feedback and Continuous Improvement (Core Function 5) C Crosswalk.

\begin{tabular}{|c|c|c|c|c|c|c|}
\hline $\begin{array}{c}\text { Line } \\
\text { Management } \\
\text { Responsibility } \\
\text { for Safety }\end{array}$ & $\begin{array}{l}\text { Clear Roles and } \\
\text { Responsibilities }\end{array}$ & $\begin{array}{c}\text { Competence } \\
\text { Commensurate } \\
\text { with } \\
\text { Responsibilities }\end{array}$ & $\begin{array}{l}\text { Balanced } \\
\text { Priorities }\end{array}$ & $\begin{array}{l}\text { Identification } \\
\text { of Safety } \\
\text { Standards } \\
\text { and } \\
\text { Requirements }\end{array}$ & $\begin{array}{c}\text { Hazard } \\
\text { Controls } \\
\text { Tailored } \\
\text { to Work } \\
\text { Being } \\
\text { Performed }\end{array}$ & $\begin{array}{l}\text { Operations } \\
\text { Authorization }\end{array}$ \\
\hline $\begin{array}{l}\text { - AA } \\
\text { - ES\&HM } \\
\text { Vol. I, Part } 2 \\
\text { - DNT Policy } \\
\text { - SAP } \\
\text { - SAR, } \\
\text { Sect. } 17.3 .2 \\
\text { - FSP, Sect. } 2 \\
\text { - FIP }\end{array}$ & $\begin{array}{l}\text { - AA } \\
\text { - ES\&HM } \\
\text { Vol. I, Part 2, } \\
\text { and Vol. 1, } \\
\text { Part } 5 \\
\text { - DNT Policy } \\
\text { - SAP } \\
\text { - SAR, } \\
\text { Sect. } 17.3 .2 \\
\text { - FSP, Sect. } 2 \\
\text { - WCM } \\
\text { - FIP } \\
\end{array}$ & $\begin{array}{l}\text { - ES\&HM } \\
\text { Vol. I, Part 2, } \\
\text { and Vol. I, } \\
\text { Part 5, and } \\
\text { Vol. IV, } \\
\text { Part } 2 \\
\text { - SAP } \\
\text { - SAR, } \\
\text { Sect. } 12.4 \\
\text { - FSP, Sect. } 5\end{array}$ & $\mathrm{~N} / \mathrm{A}$ & $\mathrm{N} / \mathrm{A}$ & $\mathrm{N} / \mathrm{A}$ & $\mathrm{N} / \mathrm{A}$ \\
\hline
\end{tabular}


This page intentionally left blank. 


\subsection{STANDARDS AND REQUIREMENTS}

The B331 AA states: "The DNT Directorate and DOE/OAK acknowledge that the references cited in the SAR and the TSR documents as approved by DOE/OAK and any conditions of approval specified in the Safety Evaluation Report form the basis of the interim Work Smart Standards (WSS) for B331. These interim WSS will be superseded by the WSS applicable to B331 operations that will result from the reconciliation of the B331 interim WSS and the LLNL site-wide WSS." Attachment A to this Appendix is a current reconciliation between the Authorization Basis Standards and Orders and the WSS. The Superblock is in the process of evaluating and reconciling the interim WSS of the AA with the WSS approved site-wide. The final outcome, as described in Section 13.0 of the main body of this description, will be a revised AA for each Superblock facility that includes the site-wide WSS. 
This page intentionally left blank. 


\subsection{EVALUATING AND RESOLVING NON-COMPLIANCES}

After consensus between DOE/OAK and LLNL, noncompliances are acted upon at the institutional, facility, or activity level as operational priorities allow. Based on a graded approach, more serious noncompliances noted in LLNL's DefTrack system, as well as concerns and action items on the Facility's Corrective Action Reporting (CAR) system, are assigned priorities at the time of their entry into the system. See also Section 6.7 above for information on tracking and closing out noncompliances and other findings. Price-Anderson Amendments Act noncompliances are tracked through the DefTrack system irrespective of their ES\&H significance. 
This page intentionally left blank. 


\subsection{FLOWDOWN OF REQUIREMENTS}

Consistent with the delineation of the flowdown of requirements (those contained in Appendix G of DOE/UC Contract 48 and nuclear safety rules) relevant to the Superblock level in the Superblock ISMS Description, B331 has developed facility-specific documentation to deal with these requirements. Table 6 presents this flowdown of requirements relevant to the B331 facility level and the corresponding B331 documentation. In the first column, those relevant requirements to $B 331$ are listed. The second column lists LLNL documents and others that have been developed to be in compliance with the requirements. The last column lists the B331specific implementing documents. Attachment $A$ to this Appendix is a current reconciliation between the Authorization Basis Standards and Orders and the WSS. It identifies those areas where changes in the Authorization Basis will be required.

Table 6. B331-specific documents that implement LLNL documents and DOE and other Federal regulations.

\begin{tabular}{|c|c|c|}
\hline Requirements & $\begin{array}{l}\text { Relevant LLNL documents or requirements } \\
\text { the Superblock follows }\end{array}$ & Relevant B331 documents \\
\hline DOE Order 420.1, Facility Safety & $\begin{array}{l}\text { - LLNL ESEHM: } \\
\text {-Volume II, Part 8, "Ionizing, Non- } \\
\text { Ionizing Radiation" } \\
\text {-Volume II, Part } 10 \text { "Emergencies, } \\
\text { Earthquakes, Fire" } \\
\text { - LLNL Fire Protection Program, UCRL-MA } \\
\text { 116646 } \\
\text { - LLNL Fire Protection Engineering Standards }\end{array}$ & FSP Chap. 7 \\
\hline $\begin{array}{l}\text { DOE Order 440.1A, Worker } \\
\text { Protection Management for DOE } \\
\text { Federal and Contractor Employees }\end{array}$ & $\begin{array}{l}\text { - LLNL ESEHM: } \\
\text {-Volume II, Part 2, "Chemical" } \\
\text { —Volume II, Part 12, "General Controls - } \\
\text { Procedures" } \\
\text { —Volume IV, Part 1, "Occupational } \\
\text { Health" } \\
\text {-Volume IV, Part 2, "Training" } \\
\end{array}$ & FSP Chap. 4 and 7 \\
\hline $\begin{array}{l}\text { DOE Order 4330.4B, Maintenance } \\
\text { Management Program }\end{array}$ & $\begin{array}{l}\text { - LLNL Maintenance Implementation Plan for } \\
\text { Nonreactor Nuclear Facilities }\end{array}$ & WCM \\
\hline $\begin{array}{l}\text { DOE Order 5400.1, General } \\
\text { Environmental Protection Program }\end{array}$ & - LLNL ESEHM, Volume III & FSP \\
\hline $\begin{array}{l}\text { DOE Order 5480.1B (Ch. 5), } \\
\text { Environmental, Safety and Health } \\
\text { Program }\end{array}$ & - LLNL ESEHM & FSP \\
\hline $\begin{array}{l}\text { DOE Order } 5480.3 \text {, Safety } \\
\text { Requirements for the Packaging and } \\
\text { Transportation of Hazardous } \\
\text { Materials }\end{array}$ & $\begin{array}{l}\text { - LLNL Onsite Hazardous Materials Packaging } \\
\text { and Transportation Safety Manual }\end{array}$ & $\begin{array}{r}\text { FSP App. L } \\
\\
\end{array}$ \\
\hline $\begin{array}{l}\text { DOE Order } 5480.4 \text { (Ch. } 4 \text { ), } \\
\text { Environmental Protection, Safety } \\
\text { and Health Protection Standards }\end{array}$ & - LLNL ESEHM & FSP \\
\hline $\begin{array}{l}\text { DOE Order } 5480.19 \text { (Ch. 1), Conduct } \\
\text { of Operations Requirements for DOE } \\
\text { Facilities }\end{array}$ & $\begin{array}{l}\text { - LLNL ESEHM, Volume 1, Part 2, "ES\&H } \\
\text { Management Requirements" }\end{array}$ & TSR; FSP; QA Plan; WCM \\
\hline
\end{tabular}

(table continued next page) 
Table 6. B331-specific documents that implement LLNL documents and DOE and other Federal regulations. (continued)

\begin{tabular}{|c|c|c|}
\hline Requirements & $\begin{array}{l}\text { Relevant LLNL documents or } \\
\text { requirements the Superblock follows }\end{array}$ & Relevant B331 documents \\
\hline $\begin{array}{l}\text { DOE Order 5480.20A, Personnel } \\
\text { Selection, Qualification, and } \\
\text { Training Requirements for DOE } \\
\text { Nuclear Facilities }\end{array}$ & $\begin{array}{l}\text { - LLNL ES\&HM: } \\
\text {-Volume 1, Part 2, "ES\&H } \\
\text { Management Requirements" } \\
\text { —Volume V, Part 1, "Personnel" } \\
\text { - LLNL Defense Systems/Nuclear Design } \\
\text { Directorate Training Plan }\end{array}$ & $\begin{array}{l}\text { B331 Training Implementation } \\
\text { Matrix; B331 Training Plan }\end{array}$ \\
\hline $\begin{array}{l}\text { DOE Order 5480.21, Unreviewed } \\
\text { Safety Questions }\end{array}$ & $\begin{array}{l}\text { - LLNL ESEHM: } \\
\text {-Volume 1, Part 2, "ES\&H } \\
\text { Management Requirements" } \\
\text {-Volume V, Part 2, "Procedures" }\end{array}$ & FSP App. G; WCM \\
\hline $\begin{array}{l}\text { DOE Order } 5480.22 \text {, Technical } \\
\text { Safety Requirements }\end{array}$ & $\begin{array}{l}\text { - LLNL ESEHM: } \\
\text {-Volume 1, Part 2, "ES\&H } \\
\text { Management Requirements" } \\
\text {-Volume V, Part 2, "Procedures" }\end{array}$ & TSR; QA Plan \\
\hline $\begin{array}{l}\text { DOE Order } 5480.23 \text { (Ch. 1), } \\
\text { Nuclear Safety Analysis Report }\end{array}$ & $\begin{array}{l}\text { - LLNL ESEHM: } \\
\text {-Volume 1, Part 2, "ES\&H } \\
\text { Management Requirements" } \\
\text {-Volume V, Part 2, "Procedures" } \\
\text { - DOE-STD-3009, Preparation Guide for } \\
\text { U.S. DOE Nonreactor Nuclear Facility } \\
\text { Safety Analysis Reports, draft, 4/94 } \\
\text { - DOE-STD-1027, Guidance on Preliminary } \\
\text { Hazard Classification and Accident } \\
\text { Analysis Techniques for Compliance with } \\
\text { DOE 5430.23 Nuclear Safety Analysis } \\
\text { Report } \\
\text { - DOE-STD-1104, Guidance on Preliminary } \\
\text { Hazard Classification and Accident Review } \\
\text { and Approval of Nonreactor Nuclear } \\
\text { Facility Safety Analysis Report }\end{array}$ & Authorization Agreement \\
\hline $\begin{array}{l}\text { DOE Order 5480.31, Startup and } \\
\text { Restart of Nuclear Facilities }\end{array}$ & $\begin{array}{l}\text { - LLNL ESEHM: } \\
\text {-Volume 1, Part 2, "ES\&H } \\
\text { Management Requirements" } \\
\text {-Volume V, Part 5, "Facilities" } \\
\end{array}$ & FSP \\
\hline $\begin{array}{l}\text { DOE Order 5484.1, Environmental } \\
\text { Protection, Safety, and Health } \\
\text { Protection Information Reporting } \\
\text { Requirements }\end{array}$ & $\begin{array}{l}\text { - LLNL ESEHM: } \\
\text { - Volume I, Part 5, "Feedback and } \\
\text { Improvement" } \\
\text {-Volume II, Part 10, Emergencies, } \\
\text { Earthquakes, Fire" }\end{array}$ & FSP \\
\hline $\begin{array}{l}\text { DOE Order } 5820.2 A \text {, Radioactive } \\
\text { Waste Management }\end{array}$ & $\begin{array}{l}\text { - LLNL Waste Acceptance Criteria } \\
\text { - LLNL TRU Waste Program Certification } \\
\text { and Quality Assurance Plan } \\
\text { - LLNL Low-Level Waste Program } \\
\text { Certification and Quality Assurance Plan } \\
\text { - LLNL Guidelines for Waste Accumulation } \\
\text { Area } \\
\text { - Defense \& Nuclear Technologies Directorate } \\
\text { Waste Minimization and Pollution } \\
\text { Prevention Plan }\end{array}$ & FSP App. L \\
\hline
\end{tabular}


Table 6. B331-specific documents that implement LLNL documents and DOE and other Federal regulations. (continued)

\begin{tabular}{|c|c|c|}
\hline Requirements & $\begin{array}{l}\text { Relevant LLNL documents or } \\
\text { requirements the Superblock follows }\end{array}$ & Relevant B331 documents \\
\hline $\begin{array}{l}10 \text { CFR } 830.120 \text { Quality Assurance } \\
\text { DOE Order } 5700.6 \mathrm{C} \text {, Quality } \\
\text { Assurance }\end{array}$ & $\begin{array}{l}\text { - Quality Assurance Plan for Nuclear } \\
\text { Facilities, Rev. 4, and LLNL [PAAA] } \\
\text { Implementation Plan, Rev. } 4 . \\
\text { - LLNL Quality Assurance Program } \\
\text { - Defense and Nuclear Technologies } \\
\text { Directorate Quality Assurance Plan }\end{array}$ & QA Plan \\
\hline $\begin{array}{l}\text { 10 CFR 835: Occupational } \\
\text { Radiation Protection } \\
\text { DOE Order 5400.5 (Ch. 2), } \\
\text { Radiation Protection of the Public } \\
\text { and the Environment }\end{array}$ & $\begin{array}{l}\text { - LLNL ES\&HM: } \\
\text {-Volume II, Part 8, “Ionizing, Non- } \\
\text { Ionizing Radiation" } \\
\text {-Volume II, Part 10, "Emergencies, } \\
\text { Earthquakes, Fire" }\end{array}$ & FSP; OSPs \\
\hline
\end{tabular}

Based on the above table, a simplified representation of the hierarchy of LLNL/B331 documents is presented in Figure 2 on the following page. 


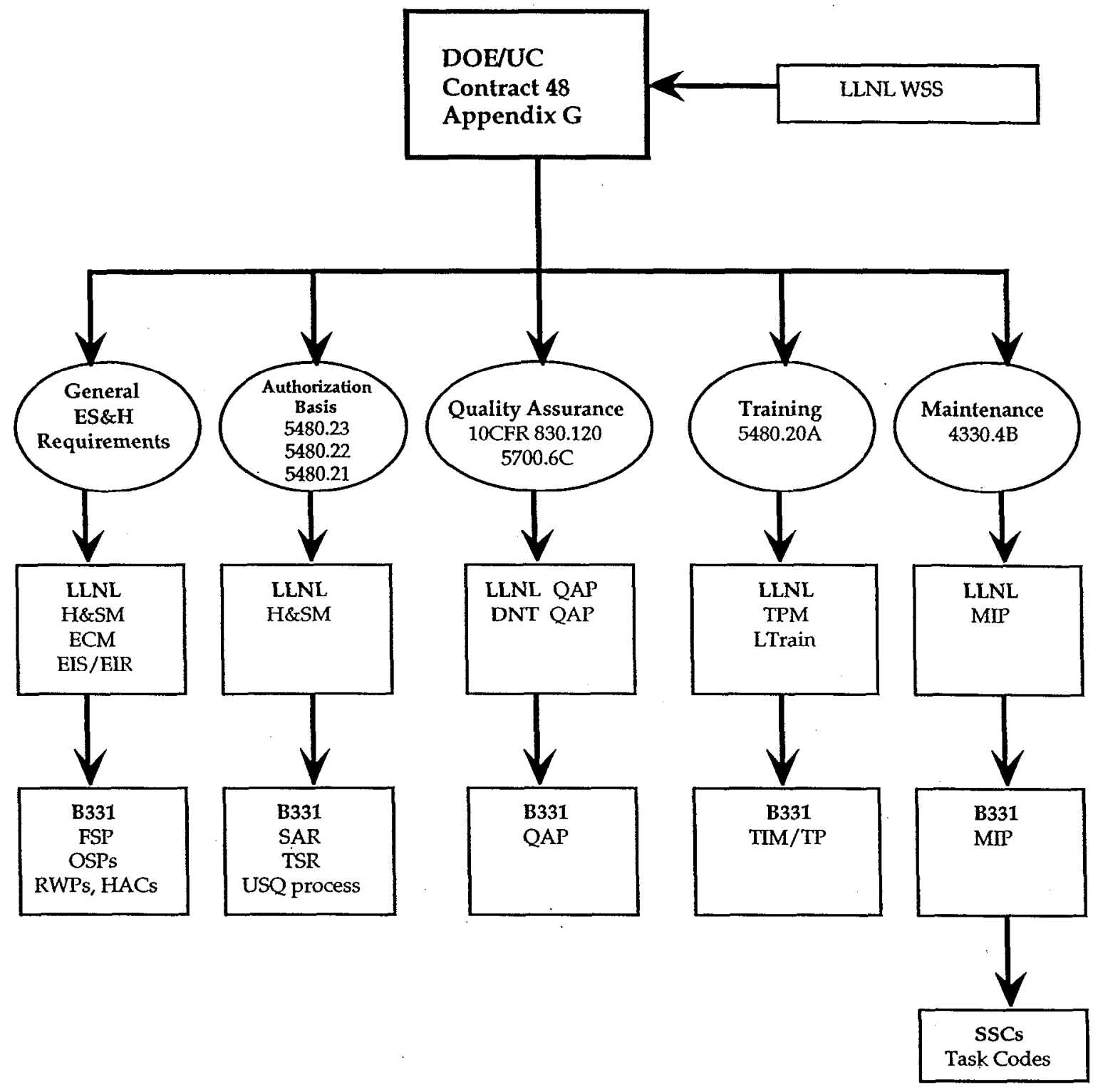

\begin{tabular}{ll} 
& \multicolumn{1}{c}{ Legend } \\
EIS/EIR: & Environmental Impact Statement/Environmental Impact Report \\
ES\&HM & LLNL ES\&H Manual \\
FSP: & Facility Safety Plan \\
HAC: & Hazard Assessment and Control Form \\
LTRAIN: & Livermore Training Records and Information Network \\
MIP: & Maintenance Implementation Plan \\
OSP: & Operational Safety Plan \\
QAP: & Quality Assurance Plan \\
RWP: & Radiological Work Permit \\
SAR: & Safety Analysis Report \\
SSCs & Structures, Systems, and Components \\
TIM/TP: & Training Implementation Matrix and Training Program \\
TPM: & Training Program Manual \\
TSR: & Technical Safety Requirement \\
USQ: & Unreviewed Safety Question
\end{tabular}

Figure 2. Simplified LLNL/B331 ES\&H document tree. 


\subsection{IMPLEMENTATION TASKS, SCHEDULE, AND MILESTONES}

Consistent with Section 14.0 of the Superblock ISMS Description, the following tasks, schedule, and milestones have been established for B331:

- Revise B331 Facility Safety Plan. (November 1999)

- Complete corrective actions for B331 ISMSV. (December 1999)

- Performance Measures implemented. (December 1999)

- Reconciliation of Site-wide ISMS and B331 ISMS. (Superblock Management will provide reconciliation plan within three months after Site-wide Phase II Verification.)

- Reconciliation of LLNL WSS and B331 interim WSS. (June 2000) 
This page intentionally left blank. 


\section{ATTACHMENT A}

\section{TRITIUM FACILITY WORK SMART STANDARDS RECONCILIATION}

\begin{tabular}{|c|c|c|c|c|}
\hline $\begin{array}{l}\text { B331 SAR Basis } \\
\text { [SAR Chapter \# in Brackets] }\end{array}$ & $\begin{array}{l}\text { Current } \\
\text { Status of } \\
\text { Each } \\
\text { Order, } \\
\text { Standard, } \\
\text { etc. }\end{array}$ & $\begin{array}{l}\text { If Order, } \\
\text { Standard, } \\
\text { etc., } \\
\text { Cancelled or } \\
\text { Superseded, } \\
\text { Replaced by }\end{array}$ & $\begin{array}{l}\text { Latest } \\
\text { Version } \\
\text { In LLNL } \\
\text { Contract/ } \\
\text { WSS? }\end{array}$ & $\begin{array}{l}\text { Auth. } \\
\text { Basis } \\
\text { Change? } \\
\text { Yes/No }\end{array}$ \\
\hline $\begin{array}{l}\text { DOE Order 232.1A, Occurrence Reporting and Processing } \\
\text { of Operations Information (September 1995) }[3,5,7,13,15 \text {, } \\
\text { 17] }\end{array}$ & $\begin{array}{l}\text { Still } \\
\text { Current }\end{array}$ & & Yes & No \\
\hline DOE Order 420.1, Facility Safety & $\begin{array}{l}\text { Still } \\
\text { Current }\end{array}$ & & Yes & No \\
\hline $\begin{array}{l}\text { DOE Order 440.1A, Worker Protection Management for } \\
\text { DOE Federal and Contractor Employees }\end{array}$ & $\begin{array}{l}\text { Still } \\
\text { Current }\end{array}$ & & Yes & No \\
\hline $\begin{array}{l}\text { DOE Order 1324.2A, Records Disposition (September } \\
\text { 1998) }[7,14]\end{array}$ & Superseded & $\begin{array}{l}21 \text { CFR } 1002 \\
\& \text { O } 1324.5 B \\
\text { (Imple } 36 \\
\text { CFR XII, } \\
\text { Subch. B) }\end{array}$ & $\begin{array}{l}\text { Yes } \\
21 \text { CFR } \\
1002\end{array}$ & Yes \\
\hline $\begin{array}{l}\text { DOE Order 1540.2, Hazardous Material Packaging for } \\
\text { Transport - Administrative Procedures (12/19/88) [3] }\end{array}$ & Superseded & $\mathrm{O} 460.1 \mathrm{~A}$ & No & No \\
\hline $\begin{array}{l}\text { DOE Order } 4330.4 B \text {, Maintenance Management Program } \\
\text { (May 1992) }[3,10,12,14,17]\end{array}$ & $\begin{array}{l}\text { Still } \\
\text { Current }\end{array}$ & & Yes & No \\
\hline $\begin{array}{l}\text { DOE Order 4700.1, Project Management System } \\
\text { (March 1987) [14] }\end{array}$ & Superseded & $\mathrm{O} 430.1 \mathrm{~A}$ & Yes & Yes \\
\hline $\begin{array}{l}\text { DOE Order 5400.1, General Environmental Protection } \\
\text { Program (Ch. 1) (June 1990) [9] }\end{array}$ & $\begin{array}{l}\text { Partially } \\
\text { Cancelled } \\
\text { by DOE }\end{array}$ & $\mathrm{O} 232.1 \mathrm{~A}$ & Yes & Yes \\
\hline $\begin{array}{l}\text { DOE Order 5400.3A, Hazardous and Radioactive Mixed } \\
\text { Waste Program (February 1989) [16] }\end{array}$ & $\begin{array}{l}\text { Cancelled } \\
\text { by DOE }\end{array}$ & O 5820.2A & Yes & No \\
\hline $\begin{array}{l}\text { DOE Order 5400.5, Radiation Protection of the Public and } \\
\text { the Environment (Ch. 2, January 1993) }[1,2,3,7,16]\end{array}$ & $\begin{array}{l}\text { Partially } \\
\text { Cancelled } \\
\text { by DOE }\end{array}$ & $\mathrm{O} 232.1 \mathrm{~A}$ & Yes & Yes \\
\hline $\begin{array}{l}\text { DOE Order 5480.1B, Environmental, Safety, and Health } \\
\text { Program (Ch. 5, May 1993) [3] }\end{array}$ & $\begin{array}{l}\text { Cancelled } \\
\text { by DOE }\end{array}$ & $?$ & No & No \\
\hline $\begin{array}{l}\text { DOE Order } 5480.3 \text {, Safety Requirements for the Packaging } \\
\text { and Transportation of Hazardous Materials, Hazardous } \\
\text { Substances, and Hazardous Wastes (July 1985) }[3,16]\end{array}$ & $\begin{array}{l}\text { Cancelled } \\
\text { by DOE }\end{array}$ & $\mathrm{O} 460.1 \mathrm{~A}$ & No & No \\
\hline $\begin{array}{l}\text { DOE Order 5480.4, Environmental Protection, Safety and } \\
\text { Health Protection Standards (Ch 4, December 1998) [1, 2, } \\
3,4,5,14,16] \\
\text { [Note: Per O 440.1, cancel Attach 2, para 2c, 2d(2)-(3), } \\
\text { 2e(1)-(8), and Attach 3, para 2c, 2d(2)-(3) and 2e(1)-(7)] }\end{array}$ & $\begin{array}{l}\text { Partially } \\
\text { Cancelled } \\
\text { by DOE }\end{array}$ & $\mathrm{O} 440.1 \mathrm{~A}$ & Yes & Yes \\
\hline
\end{tabular}




\begin{tabular}{|c|c|c|c|c|}
\hline $\begin{array}{l}\text { DOE Order 5480.7A, Fire Protection (February 1993) [1, } 2 \text {, } \\
3,4,11]\end{array}$ & $\begin{array}{l}\text { Cancelled } \\
\text { by DOE }\end{array}$ & $\begin{array}{l}\text { Part O } 420.1 \\
\text { Part } 440.1 \mathrm{~A}\end{array}$ & $\begin{array}{l}\text { Yes } \\
\text { Yes }\end{array}$ & $\begin{array}{l}\text { Yes } \\
\text { Yes }\end{array}$ \\
\hline $\begin{array}{l}\text { DOE Order 5480.8A, Ch. 1, Contractor Occupational } \\
\text { Medical Program (October 1992) [8] }\end{array}$ & $\begin{array}{l}\text { Cancelled } \\
\text { by DOE }\end{array}$ & $\mathrm{O} 440.1 \mathrm{~A}$ & Yes & Yes \\
\hline $\begin{array}{l}\text { DOE Order 5480.10, Contractor Industrial I Iygiene } \\
\text { Program (June 1985) }[3,8,11,16]\end{array}$ & $\begin{array}{l}\text { Cancelled } \\
\text { by DOE }\end{array}$ & $\mathrm{O} 440.1 \mathrm{~A}$ & Yes & Yes \\
\hline $\begin{array}{l}\text { DOE Order 5480.11, Radiation Protection for Occupational } \\
\text { Workers (June 1992) }[3,16]\end{array}$ & $\begin{array}{l}\text { Cancelled } \\
\text { by DOE }\end{array}$ & 10 CFR 835 & Yes & Yes \\
\hline $\begin{array}{l}\text { DOE Order 5480.15, DOE Laboratory Accreditation } \\
\text { Program for Personnel Dosimetry (December 1987) [3] }\end{array}$ & $\begin{array}{l}\text { Cancelled } \\
\text { by DOE }\end{array}$ & 10 CFR 835 & Yes & Yes \\
\hline $\begin{array}{l}\text { DOE Order 5480.19, Conduct of Operations Requirements } \\
\text { for DOE Facilities (May 1992) }[3,10,11,12,13,14,17]\end{array}$ & $\begin{array}{l}\text { Still } \\
\text { Current }\end{array}$ & $\begin{array}{l}\mathrm{O} 5480.19 \mathrm{Ch} \\
1\end{array}$ & Yes & Yes \\
\hline $\begin{array}{l}\text { DOE Order 5480.20A, Personnel Selection, Qualification, } \\
\text { and Training Requirements for DOE Nuclear Facilities } \\
\text { (September 1995) }[7,11,12,13,17]\end{array}$ & $\begin{array}{l}\text { Still } \\
\text { Current }\end{array}$ & & Yes & No \\
\hline $\begin{array}{l}\text { DOE Order 5480.21, Unreviewed Safety Questions } \\
\text { (November 1992) }[2,4,5,11,12,13,17]\end{array}$ & $\begin{array}{l}\text { Still } \\
\text { Current }\end{array}$ & & Yes & No \\
\hline $\begin{array}{l}\text { DOE Order 5480.22, Technical Safety Requirements (Ch. } 1 \text {, } \\
\text { September 1992) }[4,5,10,13]\end{array}$ & Superseded & $\begin{array}{l}\text { O } 5480.22 \\
\text { Ch. } 2\end{array}$ & Yes & Yes \\
\hline $\begin{array}{l}\text { DOE Order } 5480.23 \text {, Nuclear Safety Analysis Reports } \\
\text { (Ch. 1, April 1992) }[1,2,3,4,5,8,10,11,13]\end{array}$ & Superseded & $\begin{array}{l}\text { O } 5480.3 \\
\text { Ch. } 1\end{array}$ & Yes & Yes \\
\hline $\begin{array}{l}\text { DOE Order 5480.28, Natural Phenomena Hazards } \\
\text { Mitigation (January 1993) }[1,2,4,5]\end{array}$ & $\begin{array}{l}\text { Cancelled } \\
\text { by DOE }\end{array}$ & O 420.1 & Yes & Yes \\
\hline $\begin{array}{l}\text { DOE Order 5480.31, Startup and Restart of Nuclear } \\
\text { Facilities (September 1993) [5] }\end{array}$ & $\begin{array}{l}\text { Cancelled } \\
\text { by DOE }\end{array}$ & $\mathrm{O} 425.1 \mathrm{~A}$ & Yes & Yes \\
\hline $\begin{array}{l}\text { DOE Order 5482.1B, Environment, Safety, and Health } \\
\text { Appraisal Program (November 1992) [3] }\end{array}$ & $\begin{array}{l}\text { Cancelled } \\
\text { by DOE }\end{array}$ & & No & No \\
\hline $\begin{array}{l}\text { DOE Order 5483.1A, Occupational Safety and Health } \\
\text { Program for DOE Contractor Employees at Government- } \\
\text { Owned, Contractor-Operated Facilities (June 1983) [3] }\end{array}$ & $\begin{array}{l}\text { Cancelled } \\
\text { by DOE }\end{array}$ & $\mathrm{O} 440.1 \mathrm{~A}$ & Yes & Yes \\
\hline $\begin{array}{l}\text { DOE Order 5484.1, Environmental Protection, Safety, and } \\
\text { I lealth Protection Information Reporting Requirements } \\
\text { (October 1990) [3] }\end{array}$ & $\begin{array}{l}\text { Cancelled } \\
\text { by DOE }\end{array}$ & O $231.1 \mathrm{Ch} .2$ & Yes & Yes \\
\hline $\begin{array}{l}\text { DOE Order 5500.1B, Emergency Management System } \\
\text { (February 1992) [11] }\end{array}$ & $\begin{array}{l}\text { Cancelled } \\
\text { by DOE }\end{array}$ & O 151.1 Ch. 2 & Yes & Yes \\
\hline $\begin{array}{l}\text { DOE Order 5500.2B, Emergency Categories, Classes, and } \\
\text { Notification and Reporting Requirements (February 1992) } \\
{[3,11]}\end{array}$ & $\begin{array}{l}\text { Cancelled } \\
\text { by DOE }\end{array}$ & O 151.1 Ch. 2 & Yes & Yes \\
\hline $\begin{array}{l}\text { DOE Order 5500.3A, Planning and Preparedness for } \\
\text { Operational Emergencies (February 1992) }[11,15]\end{array}$ & $\begin{array}{l}\text { Cancelled } \\
\text { by DOE }\end{array}$ & O $151.1 \mathrm{Ch} .2$ & Yes & Yes \\
\hline $\begin{array}{l}\text { DOE Order 5500.7B, Emergency Operating Records } \\
\text { Protection Program (July 1992) [11] }\end{array}$ & $\begin{array}{l}\text { Cancelled } \\
\text { by DOE }\end{array}$ & O $151.1 \mathrm{Ch} .2$ & Yes & Yes \\
\hline $\begin{array}{l}\text { DOE Order 5500.10, Emergency Readiness Assurance } \\
\text { Program (February 1992) [11] }\end{array}$ & $\begin{array}{l}\text { Cancelled } \\
\text { by DOE }\end{array}$ & O $151.1 \mathrm{Ch} .2$ & Yes & Yes \\
\hline $\begin{array}{l}\text { DOE Order 5530.3, Radiological Assistance Program } \\
\text { (January 1992) [3] }\end{array}$ & $\begin{array}{l}\text { Still } \\
\text { Current }\end{array}$ & & Yes & No \\
\hline $\begin{array}{l}\text { DOE Order 5530.5, Ch. 1, Federal Radiological and } \\
\text { Monitoring Assessment Center (December 1992) [3] }\end{array}$ & $\begin{array}{l}\text { Still } \\
\text { Current }\end{array}$ & & Yes & No \\
\hline
\end{tabular}




\begin{tabular}{|l|c|c|c|}
\hline DOE Order 5700.6C, Quality Assurance (August 1991) & $\begin{array}{c}\text { Same as } \\
10 \text { CFR } \\
830.120 \& \\
\text { O } 414.1\end{array}$ & Yes & Yes \\
\hline $\begin{array}{l}\text { DOE Order 5820.2A, Radioactive Waste Management } \\
\text { (September 1988) [9, 16] }\end{array}$ & $\begin{array}{c}\text { Still } \\
\text { Current }\end{array}$ & Yes & No \\
\hline $\begin{array}{l}\text { DOE Order 6430.1A, General Design Criteria (April 1989) } \\
\text { (Will be rewritten into DOE MD.) }[1,2,4,5,11,13,14,16]\end{array}$ & $\begin{array}{c}\text { Cancelled } \\
\text { except for } \\
\text { DNFSB } \\
\text { Facilities }\end{array}$ & No & No \\
\hline \hline
\end{tabular}

\section{DOE Standards \& Guidance}

\begin{tabular}{|c|c|c|c|c|}
\hline $\begin{array}{l}\text { DOE-STD-1004-92, Root Cause Analysis Guidance (1992) } \\
\text { [11] }\end{array}$ & $\begin{array}{l}\text { Still } \\
\text { Current }\end{array}$ & & No & No \\
\hline $\begin{array}{l}\text { DOE-STD-1020-94, "Natural Phenomena Hazards and } \\
\text { Evaluation Criteria for DOE Facilities" (April 1994) [1, } 4 \text {, } \\
\text { 5] }\end{array}$ & Superseded & $\begin{array}{l}\text { STD 1020-94 } \\
\text { Ch. } 1\end{array}$ & Yes & Yes \\
\hline $\begin{array}{l}\text { DOE-STD-1021-93, "Performance Categorization Criteria } \\
\text { for Structures, Systems, and Components at DOE } \\
\text { Facilities Subjected to Natural Phenomena Hazards" } \\
\text { (July 1993) }[1,4,5]\end{array}$ & Superseded & $\begin{array}{l}\text { STD 1021-93 } \\
\text { Ch. } 1\end{array}$ & Yes & Yes \\
\hline $\begin{array}{l}\text { DOE-STD-1022-94, "Natural Phenomena Hazards Site } \\
\text { Characterization Criteria" (March 1994) [1] }\end{array}$ & Superseded & $\begin{array}{l}\text { STD 1022-94 } \\
\text { Ch. } 1\end{array}$ & Yes & Yes \\
\hline $\begin{array}{l}\text { DOE-STD-1024-92, "Guidelines for Use of Probabilistic } \\
\text { Seismic Hazard Curves at DOE Sites" (December 1992) [1] }\end{array}$ & $\begin{array}{l}\text { Still } \\
\text { Current }\end{array}$ & & No & No \\
\hline $\begin{array}{l}\text { DOE-STD-1027-92 Chg. } 1 \text { Hazard Categorization and } \\
\text { Accident Analysis Techniques for Compliance with DOE } \\
\text { Order 5480.23, Nuclear Safety Analysis Reports } 1992 \text { [3] }\end{array}$ & $\begin{array}{l}\text { Still } \\
\text { Current }\end{array}$ & & Yes & No \\
\hline $\begin{array}{l}\text { DOE-STD-1074-95, Guidelines for Evaluation of Nuclear } \\
\text { Facility Training Programs (January 1995) [12] }\end{array}$ & $\begin{array}{l}\text { Still } \\
\text { Current }\end{array}$ & & No & No \\
\hline $\begin{array}{l}\text { DOE-STD-3005-94, DOE Standard Evaluation Guidelines } \\
\text { for Accident Analysis and Safety Structures } \\
\text { (February 1994) [13] }\end{array}$ & $?$ & & No & No \\
\hline $\begin{array}{l}\text { DOE-STD-3009-94, Preparation Guide for U.S. } \\
\text { Department of Energy Nonreactor Nuclear Facility Safety } \\
\text { Analysis Reports (March 1994) }[3,5,13]\end{array}$ & Superseded & STD-3009-95 & No & No \\
\hline $\begin{array}{l}\text { DOE DP-62, Document of Example Technical Safety } \\
\text { Requirements, Rev. No. } 0 \text { (November, 1993) [5] }\end{array}$ & $\begin{array}{l}\text { Still } \\
\text { Current }\end{array}$ & & No & No \\
\hline $\begin{array}{l}\text { DOE DP-62 TSR, Interpretation Guide for the Document } \\
\text { of TSR Examples, draft (May 24, 1993) [5] }\end{array}$ & Superseded & $\begin{array}{l}\text { Draft of } \\
5 / 95, \mathrm{R} 1\end{array}$ & No & No \\
\hline $\begin{array}{l}\text { DOE/EV-005/1, "Electrical Safety Criteria for Rescarch } \\
\text { and Development Activities" [11] }\end{array}$ & $\begin{array}{l}\text { Still } \\
\text { Current }\end{array}$ & & No & No \\
\hline $\begin{array}{l}\text { DOE/EV-1830-T5, A Guide to Reducing Radiation } \\
\text { Exposure to As Low As Reasonably Achievable (ALARA), } \\
\text { U.S. Department of Energy (1980) [7] }\end{array}$ & $\begin{array}{l}\text { Still } \\
\text { Current }\end{array}$ & & No & No \\
\hline $\begin{array}{l}\text { Nuclear STD NE F3-45T, Specifications for HEPA Filters } \\
\text { Used by DOE Contractors (August 1984) [5] }\end{array}$ & Superseded & STD-3020-97 & Yes & Yes \\
\hline
\end{tabular}

Federal Codes, Standards, and Regulations

10 CFR 20, NRC Standards for Protection Against Radiation, Nuclear Regulatory Commission (>2003 only) $[1,2,11]$

10 CFR 71, Packaging of Radioactive Materials for Transport [9]

\begin{tabular}{|c|c|c|c|}
\hline $\begin{array}{c}\text { Still } \\
\text { Current }\end{array}$ & Yes & No \\
\hline $\begin{array}{c}\text { Still } \\
\text { Current }\end{array}$ & & Yes & No \\
\hline
\end{tabular}




\begin{tabular}{|c|c|c|c|c|}
\hline 10 CFR 830.120, Quality Assurance $[2,4,5,9,11,14,17]$ & $\begin{array}{l}\text { Still } \\
\text { Current }\end{array}$ & & Yes & No \\
\hline $\begin{array}{l}10 \text { CFR } 835, \text { Radiation Protection for Occupational Workers }[2, \\
3,4,5,7]\end{array}$ & $\begin{array}{l}\text { Still } \\
\text { Current }\end{array}$ & & Yes & No \\
\hline 29 CFR 1910, OSHA Standards $[2,3,4,5,8,11]$ & $\begin{array}{l}\text { Still } \\
\text { Current }\end{array}$ & & Yes & No \\
\hline $\begin{array}{l}29 \text { CFR 1960, Safety and Health Provisions for Federal } \\
\text { Employees [3] }\end{array}$ & $\begin{array}{l}\text { Still } \\
\text { Current }\end{array}$ & & No & No \\
\hline $\begin{array}{l}40 \text { CFR 61, Subpart A, National Emission Standards for } \\
\text { Hazardous Air Pollutants (NESHAP) }[2,7,9]\end{array}$ & $\begin{array}{l}\text { Still } \\
\text { Current }\end{array}$ & & Yes & No \\
\hline 40 CFR 260, Hazardous Waste Management System [9] & $\begin{array}{l}\text { Still } \\
\text { Current }\end{array}$ & & Yes & No \\
\hline $\begin{array}{l}49 \text { CFR } 172 \text { (latest revision) (Included in } 49 \text { CFR 100-199?) } \\
\text { [9] }\end{array}$ & $\begin{array}{l}\text { Still } \\
\text { Current }\end{array}$ & & Yes & No \\
\hline $\begin{array}{l}49 \text { CFR } 173 \text { (latest revision) (Included in } 49 \text { CFR 100-199?) } \\
\text { [9] }\end{array}$ & $\begin{array}{l}\text { Still } \\
\text { Current }\end{array}$ & & Yes & No \\
\hline 49 CFR 425 (c) (latest revision) [9] & $\begin{array}{l}\text { Still } \\
\text { Current }\end{array}$ & & No & No \\
\hline NRC, Regulatory Guide 3.35 [2] & $\begin{array}{l}\text { Still } \\
\text { Current }\end{array}$ & & No & No \\
\hline ERDA 76-21, Nuclear Air-Cleaning Handbook $[5,11]$ & $\begin{array}{l}\text { Still } \\
\text { Current }\end{array}$ & & No & No \\
\hline Privacy Act of 1974, Title 5, U. S. Code 552, et seq. [7] & $\begin{array}{l}\text { Still } \\
\text { Current } \\
\end{array}$ & & No & No \\
\hline \multicolumn{5}{|l|}{ National Codes, Standards \& Guides } \\
\hline National Fire Codes (NFPA) $[1,2,5,11]$ & $\begin{array}{l}\text { Still } \\
\text { Current }\end{array}$ & & Yes & No \\
\hline National Electrical Code (NFPA 70$)[2,3,4,5,11]$ & $\begin{array}{l}\text { Still } \\
\text { Current }\end{array}$ & & Yes & No \\
\hline Uniform Building Code (UBC) [2] & $\begin{array}{l}\text { Still } \\
\text { Current }\end{array}$ & & Yes & No \\
\hline ASME Boiler and Pressure Vessel Code [2] & $\begin{array}{l}\text { Still } \\
\text { Current }\end{array}$ & & Yes & $\mathrm{No}$ \\
\hline AISC, Manual of Steel Construction [2] & $\begin{array}{l}\text { Still } \\
\text { Current }\end{array}$ & & No & No \\
\hline ASHRAE Handbook $[2,11]$ & $\begin{array}{l}\text { Still } \\
\text { Current }\end{array}$ & & No & No \\
\hline ANSI/ANS 8.3-1986, Nuclear Criticality Safety [5] & $\begin{array}{l}\text { Still } \\
\text { Current }\end{array}$ & & No & No \\
\hline $\begin{array}{l}\text { ANSI/ASME N509, Nuclear Power Plant Air Cleaning Units } \\
\text { and Components [5] }\end{array}$ & $\begin{array}{l}\text { Still } \\
\text { Current }\end{array}$ & & Yes & No \\
\hline $\begin{array}{l}\text { ANSI/ASME NQA-1, Quality Assurance Program } \\
\text { Requirement for Nuclear Facilities [5] }\end{array}$ & $\begin{array}{l}\text { Still } \\
\text { Current }\end{array}$ & & No & No \\
\hline $\begin{array}{l}\text { ANSI/IEEE 344, Recommended Practices for Seismic } \\
\text { Qualification of Class I Electrical Equipment for Nuclear Power } \\
\text { Generating Stations }[4,5]\end{array}$ & $\begin{array}{l}\text { Still } \\
\text { Current }\end{array}$ & & No & No \\
\hline $\begin{array}{l}\text { ANSI/IEEE 488.1, IEEE Standard Digital Interface for } \\
\text { Programmable Instrumentation [5] }\end{array}$ & $\begin{array}{l}\text { Still } \\
\text { Current }\end{array}$ & & No & No \\
\hline
\end{tabular}




\begin{tabular}{|c|c|c|c|}
\hline $\begin{array}{l}\text { ANSI/ISA S5.1, Instrumentation Symbols and Identification } \\
\text { [5] }\end{array}$ & $\begin{array}{l}\text { Still } \\
\text { Current }\end{array}$ & No & No \\
\hline $\begin{array}{l}\text { ANSI N13.6-1966, Practice for Occupational Radiation } \\
\text { Exposure Records Systems (1972) [7] }\end{array}$ & $\begin{array}{l}\text { Still } \\
\text { Current }\end{array}$ & No & No \\
\hline $\begin{array}{l}\text { ANSI N 323, Radiation Protection Instrumentation Test and } \\
\text { Calibration (1978) [7] }\end{array}$ & $\begin{array}{l}\text { Still } \\
\text { Current }\end{array}$ & No & No \\
\hline $\begin{array}{l}\text { ANSI Y14.1, Engineering Drawing and Related } \\
\text { Documentation Practices }[4,5]\end{array}$ & $\begin{array}{l}\text { Still } \\
\text { Current }\end{array}$ & No & No \\
\hline $\begin{array}{l}\text { American Industrial Hygiene Association, Hygienic } \\
\text { Guide Series, Volumes I and II (AIHA) [8] }\end{array}$ & $\begin{array}{l}\text { Still } \\
\text { Current }\end{array}$ & No & No \\
\hline $\begin{array}{l}\text { American Industrial Hygiene Association, Workplace } \\
\text { Environmental Exposure Level Guides (AIHA) [8] }\end{array}$ & $\begin{array}{l}\text { Still } \\
\text { Current }\end{array}$ & No & No \\
\hline $\begin{array}{l}\text { Pub No. ICS 1, General Standards for Industrial Control and } \\
\text { Systems }[4,5]\end{array}$ & $\begin{array}{l}\text { Still } \\
\text { Current }\end{array}$ & No & No \\
\hline \multicolumn{4}{|l|}{ State \& Local Codes } \\
\hline $\begin{array}{l}\text { California Hazardous Waste Control Law, Health and } \\
\text { Safety Code, Chapter } 6.5 \text { (Misc. Articles in WSS) [9] }\end{array}$ & $\begin{array}{l}\text { Still } \\
\text { Current }\end{array}$ & Yes & No \\
\hline $\begin{array}{l}\text { Title } 22 \text { of the California Code of Regulations (latest } \\
\text { revision) (Misc. Articles in WSS) [9] }\end{array}$ & $\begin{array}{l}\text { Still } \\
\text { Current }\end{array}$ & Yes & No \\
\hline $\begin{array}{l}\text { City of Livermore Municipal Code, Chapter 13.32, "Waste } \\
\text { Water Collection and Treatment System" [2] }\end{array}$ & $\begin{array}{l}\text { Still } \\
\text { Current }\end{array}$ & Yes & No \\
\hline \multicolumn{4}{|l|}{ Other Guides \& References } \\
\hline $\begin{array}{l}\text { ACGIH, "TLVs-Threshold Limit Values for Chemical } \\
\text { Substances and Physical Agents in the Workroom } \\
\text { Environment with Intended Changes" (latest edition) } \\
{[2,8]}\end{array}$ & $\begin{array}{l}\text { Still } \\
\text { Current }\end{array}$ & Yes & No \\
\hline NTS Waste Acceptance Criteria, NV0-325 (Rev. 1) [9] & $\begin{array}{l}\text { Still } \\
\text { Current }\end{array}$ & No & No \\
\hline $\begin{array}{l}\text { PNL-6577, Health Physics Manual of Good Practices for } \\
\text { Reducing Radiation Exposure to As Low As Reasonably } \\
\text { Achievable ALARA (1988) [7] }\end{array}$ & $\begin{array}{l}\text { Still } \\
\text { Current }\end{array}$ & No & No \\
\hline
\end{tabular}


This page intentionally left blank. 


\section{APPENDIX C}

\section{Integrated Safety Management System (ISMS) for \\ Building 334}

October 1999

Rev. 2 


\section{About This Appendix}

Sections 1.0 through 5.0, 8.0, 12.0, and 13.0 of the Superblock Integrated Safety Management System Description, of which this appendix forms a part, covers the topics of those sections sufficiently for B334 as to make their further inclusion in this appendix redundant. This appendix, then, is composed of Sections 6.0,7.0,9.0,10.0,11.0, and 14.0, corresponding to those sections of the main document but providing details specific to B334. It also includes Attachment A, Building 334 Work Smart Standards Reconciliation, which shows Orders and Standards, derived from the B334 SAR, for comparison to the LLNL Work Smart Standards per the UC/DOE Contract Appendix G.

This document is to be used concurrently with the LLNL ISM System Description (Version 2.0, dated October 1, 1999), and the Work Smart Standards (from Contract 48 Appendix G). The Facility's Orders and Standards per the current Authorization Agreement and Work Smart Standards set as stated herein will match the institutional set with the issuance of the institution's associated implementing manuals and guidance after the reconciliation process. 


\section{TABLE OF CONTENTS}

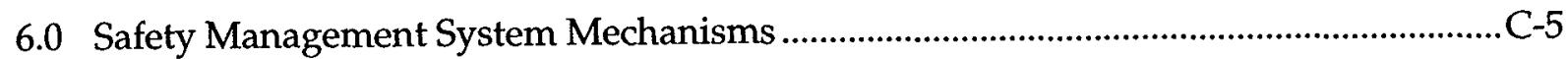

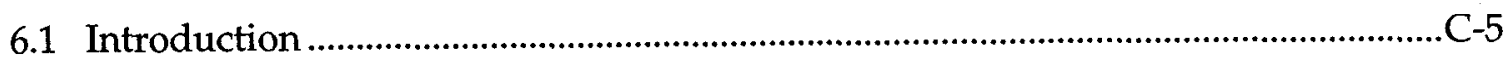

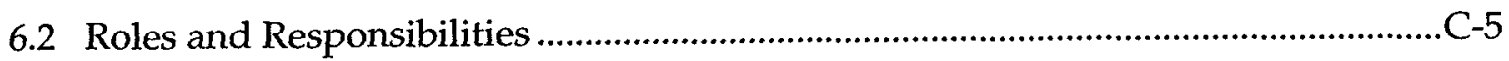

6.2.1 Line Management Responsibility for Safety ……….................................. -6

6.2.2 Clear Roles and Responsibilities.................................................................

6.2.3 Competence Commensurate with Responsibilities ......................................... -8

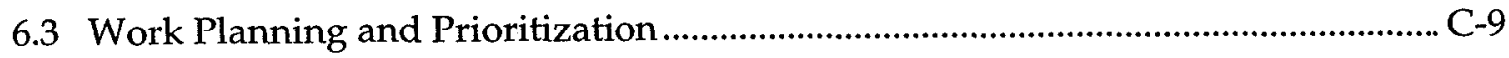

6.3.1 Define the Scope of Work ............................................................................

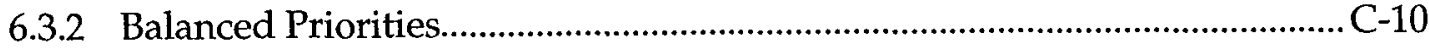

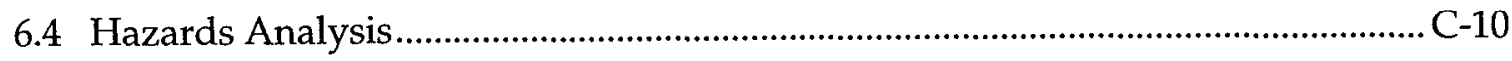

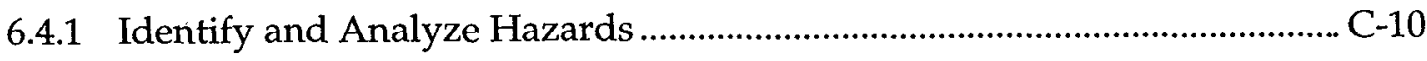

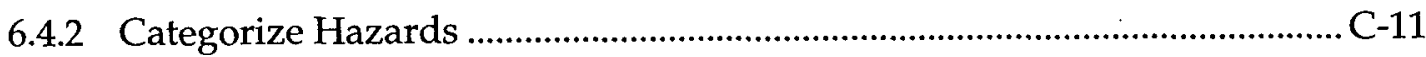

6.5 Hazard Mitigation and Control.........................................................................

6.5.1 Develop and Implement Hazard Controls …………................................... C-11

6.5.2 Identification of Safety Standards and Requirements .................................... -12

6.5.3 Hazard Controls Tailored to Work Being Performed.......................................

6.6 Work Authorization and Execution ………………..............................................

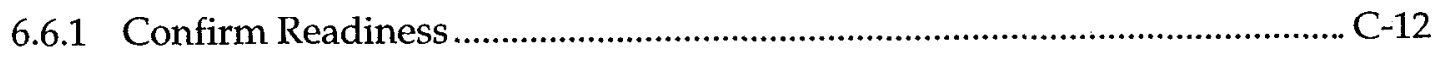

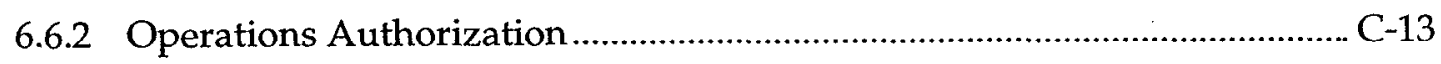

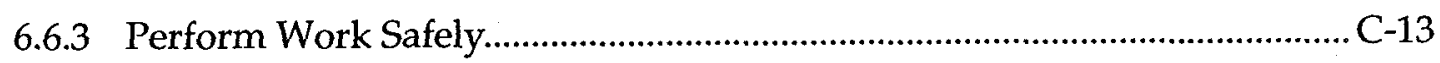

6.6.4 Performance Measures .................................................................................. -13

6.7 Performance Monitoring and Improvement.............................................................. -14

6.7.1 Collect Feedback Information ..................................................................... -14

6.7.2 Identify Improvement Opportunities and Make Changes to Improve........ -15

6.7.3 Oversight and Enforcement.......................................................................... -15

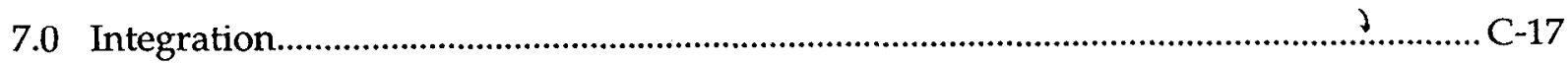

9.0 Standards and Requirements.................................................................................

10.0 Evaluating and Resolving Non-Compliances …………….......................................... C-21

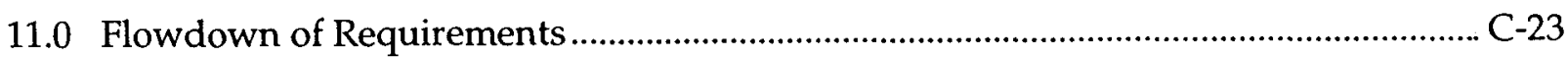

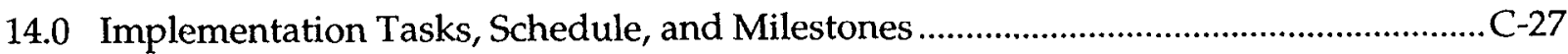

Attachment A Building 334 Work Smart Standards Reconciliation........................................ -29 
This page intentionally left blank. 


\subsection{SAFETY MANAGEMENT SYSTEM MECHANISMS}

\subsection{Introduction}

This appendix-prepared by Building 334 (B334) —is consistent with the Superblock Integrated Safety Management System (ISMS) Description and provides further specific details at the facility level and activity level. This section describes the mechanisms in place to implement an ISMS in B334, within LLNL's Superblock.

B334 is designed to provide a facility for intrinsic radiation studies and environmental testing of weapon components. The activities allowed within the facility are those involving components that contain mock explosives with mock Special Nuclear Material (SNM), SNM, or mock explosives with SNM.

B334 operates under the authority of an Authorization Agreement (AA) between LLNL's Associate Director for Defense \& Nuclear Technologies (AD/DNT) and the DOE Oakland Operations Manager, signed January 28, 1999. As a Nuclear Hazard Category 3 facility, B334 requires a less rigorous and detailed safety description than, for example, Building 332, a Category 2 facility. The B334 safety documents include the following:

- At the institutional level, the LLNL Environmental, Safety and Health Manual (ES\&HM).

- At the facility level, the B334 Facility Safety Plan (FSP), the B334 Safety Analysis Report (SAR), and the B334 Technical Safety Requirements (TSR).

- At the activity level, the FSP, Operational Safety Plans (OSPs) and Work Permits (WPs).

The ES\&HM establishes general ES\&H requirements. The SAR, the TSR, and the FSP establish the specific safety basis and safety controls for the facility. The OSPs and WPs assess the responsibilities, hazards, and controls for each operation at the activity level. These safety practices at various levels are integrated to form the ISMS.

As described in Section 7.2 of the Superblock Integrated Safety Management System Description, the five core functions of the ISMS are implemented at all levels: from the Superblock level, to the facility level, to the activity level. The key information, processes, and requirements associated with the implementation of each core function at these three levels are depicted in Figure 4 in Section 7.2 of the main body of this Description.

A matrix portraying a crosswalk of the programs, systems, and procedures in place to meet ISMS functions and principles in B334 is provided in Section 7.0, Integration.

\subsection{Roles and Responsibilities}

Line Management Responsibility for Safety (Guiding Principle 1)

Clear Roles and Responsibilities (Guiding Principle 2) 
Competence Commensurate with Responsibility (Guiding Principle 3)

\subsubsection{Line Management Responsibility for Safety}

B334 is managed by a Facility Manager (FM) with the support of a Facility Staff. The Facility Manager is also the Program Manager (PM) in the facility. Therefore, throughout this Appendix, reference to line management and roles and responsibilities in B334 specify only the FM for both facility and programmatic responsibilities. The Facility organization chart is shown in Figure 1. The AD/DNT, through the Nuclear Material Technologies (NMT) Program Leader and his deputies for Programs and Facility Operations, has delegated to the FM the authority for, and holds him responsible for, operating the Facility and ensuring that the Facility meets Laboratory Environmental, Safety and Health (ES\&H) requirements. The FM's general ES\&H responsibilities are detailed in the ES\&HM, Volume I, Part 2, while B334-specific responsibilities are detailed in Section 2 of the FSP, the Nuclear Materials Technology Program Management Plan, and Chapter 5 of the SAR. These responsibilities are summarized as follows:

- Ensure that all activities in the Facility are conducted safely.

- Maintain a current Emergency Response Plan and conduct training exercises as required in the Plan.

- Ensure that the Training Implementation Matrix/Training Program (TIM/TP) is implemented for Facility workers.

- Ensure that the Facility ES\&H documents such as the SAR, TSR, FSP, and OSPs are reviewed on a timely basis.

- Implement the Quality Assurance program.

- Establish systems to ensure continuous feedback and improvement based on lessons learned.

- Require that personnel conform to the facility's TIM through constant assessment by the NMTP Training Manager that the required training is current.

\subsubsection{Clear Roles and Responsibilities}

Additional responsibilities for the B334 organization are discussed in Chapter 6 of the B334 Safety Analysis Report (SAR) and in Section 2 of the B334 Facility Safety Plan (FSP). Appendix A of the B334 FSP further details the safety responsibility chain for B334. The responsibilities of the B334 FM, Responsible Individuals, Building Coordinator, employees, and contract personnel are summarized below.

\section{Facility Manager}

The FM is responsible for the safe operation of the facility through implementation of and compliance with the applicable elements of the "Conduct of Operations" as required by the ES\&HM, Volume I, Part 2, the FSP, OSPs, and Laboratory manuals (e.g., Health \& Safety Manual, Environmental Compliance Manual). The FM implements the ES\&H program for B334 and ensures that ES\&H deficiencies are corrected, and develops and implements emergency response and self-help plans and procedures. Additional facility-related responsibilities may be 


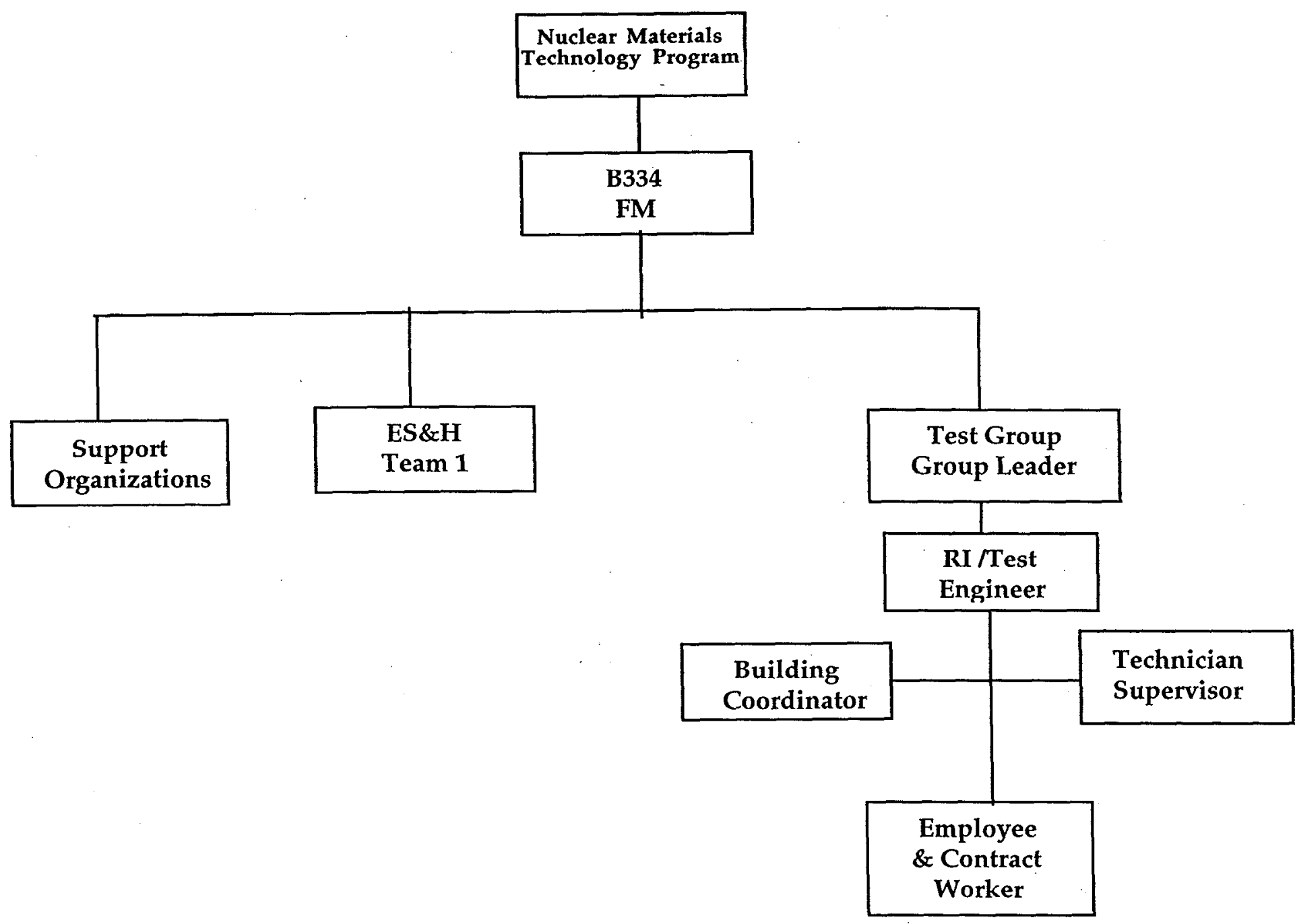

Figure 1. B334 Organization Chart. 
assigned by the Associate Director for Defense \& Nuclear Technologies through the NMT Program Leader and his deputies.

\section{Responsible Individuals}

Responsible Individuals (RIs) are test engineers, project leaders, experiment leaders, area supervisors, resident technicians, etc. As line management, these persons have been assigned the responsibility from their programmatic $A D$ to ensure that anyone working or visiting in their area, including non-LLNL personnel, is properly trained, supervised, or escorted and to ensure that requirements of the FSP, the ES\&HM, and all applicable OSPs are understood and adhered to. They ensure that all personnel regularly working in the area have read the FSP, that they take reasonable precautions to protect themselves, and that they perform only those tasks that can be accomplished safely. They are responsible for maintaining work areas according to prescribed standards and monitoring work activities (ES\&HM, Volume I, Part 2).

\section{Building Coordinator}

The Building Coordinator is responsible for coordinating all activities involving crafts, contractors, and Safeguards and Security within the building, and serving as the primary contact for support organizations. The Building Coordinator is responsible to the FM for confirming that the support (e.g., maintenance) programmatic personnel have implemented ES\&H requirements and controls in accordance with the Facility FSP and OSPs.

\section{Employees and Contract Personnel}

Employees and contract personnel working in the facility are responsible for performing their work and attending and completing all assigned ES\&H training courses required to perform their tasks in a responsible, safe, and environmentally sound manner. They are also responsible for reading and following the requirements of the FSP, applicable OSPs, the ES\&HM, and other applicable ES\&H documents in performing their work. In addition, under the requirements of the ES\&HM, Volume I, Part 2, "all employees are responsible for...requesting that work be stopped if they observe others performing an operation (or are in a situation) that is perceived to be imminently dangerous to health, safety, or the environment...."

\subsubsection{Competence Commensurate with Responsibilities}

Programs to establish and maintain competency for B334 personnel are prescribed in the ES\&HM, Volume V, Part 1, "Personnel," and are described in Section 6.5 of the B334 SAR and Section 5 of the FSP. Training requirements may be established by payroll or support programs and facility organizations. Payroll and support organizations establish general requirements, such as basic competency and general safety courses, and are responsible for their employees completing institutional training requirements. Facility-specific training and qualification are listed in Section 5 of the B334 FSP. To monitor the training required for and accomplished by B334 employees, the FM utilizes the LLNL's Livermore Training Records and Information Network (LTRAIN) program. The (LTRAIN) program is a software tool that aids supervisors in establishing required employee training and tracks the training required for and accomplished by employees. 
Worker participation in safety planning and implementation is ensured through a number of mechanisms, including FSP briefings, pre-job planning, etc., which invite input from workers at all levels.

\subsection{Work Planning and Prioritization}

Define the Scope of Work (Core Function 1)

Balanced Priorities (Guiding Principle 4)

\subsubsection{Define the Scope of Work}

Currently, B334 supports the DNT mission by:

- Conducting dynamic and thermal tests on weapon components in the Engineering Test Bay (ETB) section of the Facility.

- Conducting Intrinsic Radiation Measurements of various components in the Radiation Measurement section of the Facility.

The Authorization Agreement (AA) between the AD/DNT and DOE/OAK establishes and defines authorized operations in B334. In translating the mission into work activities, ES\&H considerations are integrated into the work planning activity to ensure that the work is accomplished while protecting the workers, the public, and the environment. All work performed in B334 must be within the safety envelope defined in the B334 Authorization Agreement (AA), which includes the SAR and TSR documents as approved by DOE/OAK. The FSP and the OSPs further describe specific controls for operations to ensure they are within the bounds of the SAR. The FSP and the OSPs define the controls applicable for operations based upon the hazards assessment performed for each activity. A B334 Work Control/Design Change Control Manual (Work Control Manual or WCM) provides directions on the Facility's procedures for new work and work controls. The FM is the first contact for programmatic representatives desiring to use any part of the facility. The WCM includes requirements for Unreviewed Safety Question (USQ) determinations to ensure the activities remain within the terms of the AA.

In translating this mission into work activity per the WCM, the programmatic sponsors define activity work scopes. The program RI submits the work request to the DNT (for radiation measurements) or DTED (for others) Test Engineer, who reviews the request with the FM to ensure that the work is within the scope of the AA-authorized operations in the B334 FSP. The Test Engineer then submits the written test plans and schedule for approval by the FM and the cognizant group leader. All activities that are not covered by the FSP but still are within the B334 SAR safety envelope, as determined by the FM with the assistance of the ES\&H Team 1 safety experts, require an OSP. The FM is the primary source of assistance in coordinating any new activities requiring an OSP. The Criticality Safety Engineer (CSE) also reviews any activity containing SNM, and the test plan is approved only if the CSE certifies that a criticality is not a credible event.

In addition to the programmatic work activities, the WCM provides standards for Facilityrelated maintenance work activities in B334. Maintenance activities in B334 are performed for 
the purpose of ensuring reliable operations and maintaining the safety envelope, and consist of preventive and corrective work.

\subsubsection{Balanced Priorities}

B334 complies with the LLNL policy of performing work in a manner that protects the health and safety of employees and the public, preserves the quality of the environment, and prevents property damage. ES\&H matters are priority considerations in the planning and execution of all work. Safe methods are established by the FM with the assistance of the ES\&H Team 1 for the work to be accomplished according to the needs of the programs and within the budget established, or the FM will not approve the activity to commence.

Funding for operations and maintenance in B334 comes from DNT programmatic funding. The allocation of DNT programmatic funding is determined by the AD/DNT based upon annual budget plans provided by the Program Managers and NMT Program Leader. Requests for additional funding (e.g., for emergency use) are considered on a case-by-case basis and provided according to justification and needs by the NMT Program Leader, programmatic managers, and the AD/DNT. Emergency facility maintenance requirements would be provided by the AD/DNT through the NMT Program Leader.

Budgeting and spending generally are directly programmatic based. Programmatic personnel charge their time directly to programmatic accounts. They usually are not B334 residents, although technicians and machinists may be both resident and dedicated to a program. Facility personnel include the FM and resident technicians.

\subsection{Hazards Analysis}

Analyze Hazards (Core Function 2)

\subsubsection{Identify and Analyze Hazards}

The B334 Safety Analysis Report (SAR) identifies and analyzes the hazards for the building. The SAR addresses bounding accidents as well as the hazards associated with hazardous materials used within the building. The SAR and its hazard analysis techniques utilize great rigor to evaluate the hazards and establish controls to minimize risks to the facility. workers, the public, and the environment. SAR hazards analyses are performed by Subject Matter Experts (SMEs) in concert with Facility personnel and workers acquainted with operations and activities, using "failure mode and effects analysis" in accordance with DOE STD 3009 and DOE O 5480.23.

Normal operations in B334 are limited to general industrial and low-level radiation hazards. Industrial hazards are controlled through the Industrial Hygiene, Fire Protection, and Industrial Safety Programs, and radiation hazards are controlled though the Radiation Protection programs. These programs are derived from guidelines defined in the ES\&HM, the FSP, and OSPs. RIs, working in concert with workers, Facility Management, and ES\&H Team 1, determine at what levels a documented evaluation shall be performed. New proposed activities and equipment installations, major changes to existing activities, equipment modifications, and maintenance and other work activities are screened, analyzed, and authorized through meeting the requirements in the WCM. This manual provides guidance and requirements for hazards 
identification and assessment; establishment of appropriate controls and implementation of those controls; and the methods and requirements to authorize the work to be accomplished. Controls identified by this process that are not already covered in the FSP are delineated in Work Permits (for Facility Operations work) or OSPs (for programmatic work).

Based upon potential hazards, the FSP (Section 4) defines which operations will be authorized and under what controls. Beyond those bounds, additional reviews, analyses, OSPs, etc., are required, resulting in defined safety controls that must be met.

\subsubsection{Categorize Hazards}

B334 is categorized as a Nuclear Hazard Category 3-nonreactor nuclear facility using the methodology set forth in DOE-STD-1027-92 and determined in the DOE-approved SAR. Nonnuclear hazards within B334 are further categorized to be low (under DOE Order 5481.1B) as stated in the B334 SAR.

Activities in B334 are assessed routinely during the planning phases of an activity as prescribed in the WCM. As the planning of the activity progresses, the following steps are prescribed:

(1) Identify the safety and health hazards and the environmental concerns of the activity (conducted by all participants, including workers).

(2) Evaluate the risk of conducting the operation within the Facility's authorization basis per the Facility's Unreviewed Safety Questions (USQ) process.

(3) Identify the controls necessary to conduct the operations safely and in compliance with accepted standards and regulations.

(4) Identify and prepare documents necessary to conduct the operation and implement the controls. These documents may include OSPs, operating procedures, permits, or other documentation such as decontamination and disposition plans and Quality Assurance plans.

A comprehensive system to tailor the controls as an enhancement to the ES\&HM, Volume I, Part 2, is in development, called the "CHOOSE" (Controls/Hazards Opcrations-Oriented Safety Envelope) database. It describes a technique to use a graded approach for achieving an acceptable level of risk. The graded approach identifies the level of effort that would be cost effective or commensurate with the hazards involved.

\subsection{Hazard Mitigation and Control}

Develop and Implement Hazard Controls (Core Function 3)

Identification of Safety Standards and Requirements (Guiding Principle 5)

Hazard Controls Tailored to Work Being Performed (Guiding Principle 6)

\subsubsection{Develop and Implement Hazard Controls}

The B334 SAR was prepared and is reviewed annually by the FM with assistance from appropriate safety experts. It identifies hazards and accident scenarios, the potential 
occurrences of which are controlled through engineered and administrative controls. In support of these controls, the Facility has a formally established set of Technical Safety Requirements (TSRs) and operating practices. The B334 FSP specifies operating practices, access controls and requirements, and general building rules. Chapters 4 through 6 of the SAR describe the various B334 safety programs. The following subsections (6.5.2 and 6.5.3) describe how the controls are established.

\subsubsection{Identification of Safety Standards and Requirements}

B334 operations conform to all applicable State and Federal laws, statutes, rules, and DOE directives. B334 uses appropriate national consensus standards and DOE Guides and technical standards, and provides for DOE/OAK review and concurrence. The current safety-related administrative and reporting requirements are specified in the DOE-approved B334 AA and the Facility's SAR and TSR documents. Attachment A to this Appendix is a current reconciliation between the Authorization Basis Standards and Orders and the WSS. It identifies those areas where changes in the Authorization Basis will be required.

\subsubsection{Hazard Controls Tailored to Work Being Performed}

Activities in B334 are assessed during the planning phases of an activity as prescribed in the ES\&HM, Volume I, Part 2. The controls are tailored as suggested in the ES\&HM, which describes a technique for using a graded approach to achieve an acceptable level of risk. The graded approach identifies the level of effort that would be cost effective or commensurate with the hazard involved. As the planning of the activity progresses, the FM ensures that each the following steps is followed:

(1) The program RI and the FM conduct an evaluation of the hazard of conducting the operation safely and in compliance with the FSP scope of work. ES\&H Team 1 or other appropriate safety experts are consulted as needed.

(2) The controls necessary to conduct the operations safely and in compliance with accepted standards and regulations are identified.

(3) Documents necessary to conduct the operation and implement the controls are identified and prepared. These documents may include test plans, OSPs, operating procedures, and/or work permits.

(4) The activity document is reviewed by and approved by the FM and the cognizant group leader.

\subsection{Work Authorization and Execution}

Perform Work within Controls (Core Function 4)

Operations Authorization (Guiding Principle 7)

\subsubsection{Confirm Readiness}

After verifying that the work is within the AA safety envelope, the B334 FM utilizes the ES\&HM, Volume I, Part 2, as the guide for conducting readiness reviews for new or revised 
operations, and Volume 5, Part 5, for the startup or restart of facility and programmatic activities. The reviews ensure that:

- Hardware and tools are available, the facility is operable, and the equipment is tested and calibrated.

- The required safety systems are correctly installed and tested and the appropriate personnel are trained in the use of these systems.

- The tests and/or activities are ready, test plans are complete, maintenance of safety systems is scheduled, ES\&H documentation is complete, and work permits are issued as required.

- Personnel know their responsibilities and are trained or certified as required for the operations.

All work is subjected to the USQ process to verify that it is within the AA safety envelope.

\subsubsection{Operations Authorization}

The B334 FSP is approved by the AD/DNT, authorizing the stated activities. Test plans/activities are approved by the FM and the appropriate group leader. All other activities are approved by the FM and the Program Manager, if applicable.

\subsubsection{Perform Work Safely}

Safety requirements are incorporated into the FSP, OSPs, and operating procedures as required. B334 has implemented the requirements of the ES\&HM, Volume I, Part 2. Facility maintenance is conducted in accordance with an approved LLNI. maintenance implementation plan (MIP). The WCM describes the process for review by management and workers and determination of appropriate controls. As stated in Section 6.2.2, above, workers understand under LLNL and Facility procedures that they have the right and responsibility to stop potentially unsafe work and report unsafe situations.

Maintenance activities such as welding, burning, or other hazardous operations (see the ES\&HM, Volume II, Part 10) require LLNL work permits to ensure that personal and operational safety controls are adequate for the proposed work and that the work has specific written approval.

\subsubsection{Performance Measures}

Consistent with Section 6.6.4 of the Superblock ISMS Description, Building 334, as part of the Superblock, will contribute to the institutional performance objectives, criteria, and measures (POCMs). ES\&H self-assessment is performed regularly by the Facility staff in accordance with the DNT ES\&H Self-Assessment Plan to identify areas of improvement. Independent assessment and oversight are provided by the DNT Assurance Manager and the LLNL Assurance Review Office. External assessment and oversight are performed by DOE. Assessment information, occurrence reporting data, and incident analysis/accident investigation findings are taken from across the Laboratory. This information is used to arrive 
at performance measurement goals set by the University of California and the DOE annually. The goals of individual LLNL facilities support these performance measures.

B334 performance goals that support the current performance measures include:

- Implementing the five core functions of Integrated Safety Management based on this ISMS Description (App. F, Part II-2, Criteria 1.4).

- Maintaining zero toxic material and physical agent exposure (App. F, Part I-2, Criteria 1.4.d).

- Maintaining zero incidence of environmental regulatory violations and releases (App. F, Part II-2, Criteria 1.4.h).

- Reducing standard occupational safety and health injury rates to a level that is at or below the mean rate for the DOE complex. We propose to accomplish this by raising worker consciousness through improved communication of accident- and injuryprevention strategies (App. F, Part II-2, Criteria 1.4.e).

- Reducing the generation of low-level, mixed, and hazardous wastes to meet DOE's pollution-prevention goals for the year 2000 (App. F, Part II-2, Criteria 1.4.g).

- Reducing safety--related occurrences, also through raising worker consciousness, similarly to the occupational injury and illness item above.

Quarterly, the Facility Management will collect the required data from occurrence reports, injury and lost time reports, and surveys of programmatic feedback to compile an Objective Performance Measures Report. Annually, this information will be reported to the AD/DNT. The annual institutional performance assessment by the Laboratory, University of California, and DOE/OAK will reflect the contributions of B334 to the Laboratories overall performance in accordance with UC/DOE Contract 48.

\subsection{Performance Monitoring and Improvement}

Provide Feedback and Continuous Improvement (Core Function 5)

\subsubsection{Collect Feedback Information}

LLNL has a documented hierarchy of assessments that provide data and information for the feedback process. As for all facilities within the Superblock, B334 uses the following process to collect feedback information:

- DNT Self-Assessment Plan (DNT-SA.4), which includes the monitoring and tracking of corrective actions using the LLNL Deficiency Tracking (DefTrack) system.

- NMTP Feedback and Improvement Program (FIP), which includes systems for identifying deficiencies and providing lessons learned (see also Sections 6.7 in both the main document and Appendix A for more detail).

- Internal assessment, such as Laboratory audits, LLNL Lessons Learned Program, Occurrence Reports, Incident Analysis findings.

- External assessments conducted by organizations outside of DNT. 
Corrective actions required for reportable occurrences are determined through formal Root Cause Analysis by the NMT Program Leader, with assistance from his deputies. Identification of potentially serious safety-related trends based on DefTrack data is included in the Annual ES\&H Report by the AD/DNT Assurance Manager. The FM determines the causes of those trends as they relate to activities conducted in B334. Because of the relatively small number of building residents and workers, B334 personnel are also personally encouraged to provide feedback to the FM directly. Because of the importance placed by the AD/DNT, NMT Program Leader, and FM, included in the stop work empowerment is the assurance that employees who use it will be heeded without question or restraint. The facility maintains an internal Corrective Action Request (CAR) system for documenting feedback and tracking closure. The NMTP FIP Master Action Database (MAD) consolidates and tracks to closure DefTrack deficiencies, CAR items and any other concerns identified by the FM.

\subsubsection{Identify Improvement Opportunities and Make Changes to Improve}

As stated above, B334 uses DefTrack to track the status of ES\&H deficiencies resulting from assessments conducted per the DNT Self-Assessment Plan and from all formal internal and external assessments. Additionally, corrective actions resulting from Occurrence Reports, Incident Analysis findings, and Price-Anderson Amendment Act issues are entered and tracked through DefTrack per DNT policy. The DefTrack system is the primary tool for identifying trends indicative of improvement opportunities and for tracking deficiencies to closure. NMTP policy also requires lesser concerns and commitments to be tracked in the MAD, which includes sorting capabilities to assist in identifying areas of concern on a macro basis (such as compliance effectiveness and ISMS implementation) as well as the micro basis typical of a database.

The DefTrack and MAD systems track and document deficiencies and feedback for closure when corrective actions are completed. These processes ensure that improvements will be made from information identified through assessment, feedback, lessons learned, and other sources. The FM is responsible for evaluating and implementing the improvements.

\subsubsection{Oversight and Enforcement}

Chapter 2 of the FSP defines the responsibility and authority of Facility Management with regard to oversight and enforcement. In general terms, for programmatic work, Facility Management provides oversight, and program line managers have enforcement responsibility. The FM performs the role of Program Manager for activities in B334. The FM has the responsibility for assessing the adequacy of operations, equipment, and procedures, while the line manager has the responsibility for making corrections to the FM's satisfaction. For the Facility operating systems, the FM has the responsibility for both oversight and enforcement of adequate operations, equipment, and procedures. Additional oversight is provided at the next higher level by the NMT Program Leader, and by DOE/OAK through the continuous presence in the Superblock of a resident Facility Representative. 
This page intentionally left blank. 


\subsection{INTEGRATION}

The integration of the functions and principles of ISMS in Building 334 are summarized in a matrix shown in Tables 1 through 5. The documents listed establish and implement the Facility standards pertaining to the Core Functions and Guiding Principles for operations and programmatic activities.

The following abbreviations are used in Tables 1 through 5:

AA - Authorization Agreement

DNT Policy - ES\&H Policy for the DNT Directorate, AD letter dated 2/2/96

ES\&HM - LLNL Environmental, Safety and Health Manual

FIP - NMTP Feedback and Improvement Program

FSP - Facility Safety Plan

N/A - Not Applicable

OSP - Operational Safety Plan

SAP - DNT Self-Assessment Plan (DNT-SA.4)

SAR - Safety Analysis Report

TIM - Training Implementation Matrix

TSR - Technical Safety Requirement

WCM - Work Control Manual

WP - Work Permit

Table 1. Define the Scope of Work (Core Function 1) Crosswalk.

\begin{tabular}{|c|c|c|c|c|c|c|}
\hline $\begin{array}{c}\text { Line } \\
\text { Management } \\
\text { Responsibility } \\
\text { for Safety }\end{array}$ & $\begin{array}{c}\text { Clear Roles } \\
\text { and } \\
\text { Responsibilities }\end{array}$ & $\begin{array}{c}\text { Competence } \\
\text { Commensurate } \\
\text { with } \\
\text { Responsibilities }\end{array}$ & $\begin{array}{l}\text { Balanced } \\
\text { Priorities }\end{array}$ & $\begin{array}{l}\text { Identification } \\
\text { of Safety } \\
\text { Standards } \\
\text { and } \\
\text { Requirements }\end{array}$ & $\begin{array}{l}\text { Hazard } \\
\text { Controls } \\
\text { Tailored } \\
\text { to Work } \\
\text { Being } \\
\text { Performed }\end{array}$ & $\begin{array}{l}\text { Operations } \\
\text { Authorization }\end{array}$ \\
\hline $\begin{array}{l}\text { - ES\&HM } \\
\text { Vol. I, Part } 2 \\
\text { - DNT Policy } \\
\text { - FSP, Sect. } 3 \\
\text { - SAR, } \\
\text { Sect. } 2.3 .2 \\
\text { - WCM }\end{array}$ & $\begin{array}{l}\text { - ES\&HM } \\
\text { Vol. I, Part } 2 \\
\text { - DNT Policy } \\
\text { - FSP, Sect. 2, } \\
3, \& 4 \\
\text { - SAR, } \\
\text { Sect. } 2.3 .2 \\
\text { - WCM }\end{array}$ & $\begin{array}{l}\text { ES\&HM } \\
\text { Vol. I, Part 2, } \\
\text { and Vol. IV, } \\
\text { Part } 2 \\
\text { TIM }\end{array}$ & $\begin{array}{l}\text { - ES\&HM } \\
\text { Vol. I, } \\
\text { Part } 2 \\
\text { - DNT } \\
\text { Policy } \\
\text { - WCM }\end{array}$ & $\mathrm{N} / \mathrm{A}$ & $\mathrm{N} / \mathrm{A}$ & $\mathrm{N} / \mathrm{A}$ \\
\hline
\end{tabular}

Table 2. Analyze the Hazards (Core Function 2) Crosswalk.

\begin{tabular}{|c|c|c|c|c|c|c|}
\hline $\begin{array}{c}\text { Line } \\
\text { Management } \\
\text { Responsibility } \\
\text { for Safety }\end{array}$ & $\begin{array}{c}\text { Clear Roles } \\
\text { and } \\
\text { Responsibilities }\end{array}$ & $\begin{array}{c}\text { Competence } \\
\text { Commensurate } \\
\text { with } \\
\text { Responsibilities }\end{array}$ & $\begin{array}{l}\text { Balanced } \\
\text { Priorities }\end{array}$ & $\begin{array}{l}\text { Identification } \\
\text { of Safety } \\
\text { Standards } \\
\text { and } \\
\text { Requirements }\end{array}$ & $\begin{array}{c}\text { Hazard } \\
\text { Controls } \\
\text { Tailored } \\
\text { to Work } \\
\text { Being J } \\
\text { Performed }\end{array}$ & $\begin{array}{l}\text { Operations } \\
\text { Authorization }\end{array}$ \\
\hline $\begin{array}{l}\text { - } \text { AA } \\
\text { - ES\&HM } \\
\text { Vol. I, Part } 2 \\
\text { - FSP, Sect. } 3 \\
\text { - DNT Policy } \\
\text { - OSPs } \\
\text { - WCM }\end{array}$ & $\begin{array}{l}\text { - AA } \\
\text { - ES\&HM } \\
\text { Vol. I, Part 2, } \\
\text { and Vol. I, } \\
\text { Part } 4 \\
\text { - DNT Policy } \\
\text { - FSP, Sect. } 3 \text { \& } \\
5 \\
\text { - OSPs } \\
\text { - WCM }\end{array}$ & $\begin{array}{l}\text { - AA } \\
\text { - ES\&HM } \\
\text { Vol. I, Part 2, } \\
\text { and Vol. IV, } \\
\text { Part } 2 \\
\text { - TSR } \\
\text { - TIM }\end{array}$ & $\mathrm{N} / \mathrm{A}$ & $N / A$ & $\mathrm{~N} / \mathrm{A}$ & $\mathrm{N} / \mathrm{A}$ \\
\hline
\end{tabular}


Table 3. Develop and Implement Hazard Controls （Core Function 3) Crosswalk.

\begin{tabular}{|c|c|c|c|c|c|c|}
\hline $\begin{array}{c}\text { Line } \\
\text { Management } \\
\text { Responsibility } \\
\text { for Safety }\end{array}$ & $\begin{array}{c}\text { Clear Roles } \\
\text { and } \\
\text { Responsibilities }\end{array}$ & $\begin{array}{c}\text { Competence } \\
\text { Commensurate } \\
\text { with } \\
\text { Responsibilities }\end{array}$ & $\begin{array}{l}\text { Balanced } \\
\text { Priorities }\end{array}$ & $\begin{array}{c}\text { Identification } \\
\text { of Safety } \\
\text { Standards } \\
\text { and } \\
\text { Requirements }\end{array}$ & $\begin{array}{l}\text { Hazard } \\
\text { Controls } \\
\text { Tailored } \\
\text { to Work } \\
\text { Being } \\
\text { Performed }\end{array}$ & $\begin{array}{l}\text { Operations } \\
\text { Authorization }\end{array}$ \\
\hline $\begin{array}{l}\text { - AA } \\
\text { - ES\&HM } \\
\text { Vol. I, Part } 2 \\
\text { - DNT Policy } \\
\text { - FSP, Sect. } 3 \\
\text { - WCM }\end{array}$ & $\begin{array}{l}\text { - AA } \\
\text { - ES\&HM } \\
\text { Vol. I, Part 2, } \\
\text { and Vol. I, } \\
\text { Part } 4 \\
\text { - DNT Policy } \\
\text { - FSP, Sect. } 3 \text { \& } \\
5 \\
\text { - OSPS } \\
\text { - WCM }\end{array}$ & $\begin{array}{l}\text { - ES\&HM } \\
\text { Vol. I, Part 2, } \\
\text { and Vol. I, } \\
\text { Part 4, and } \\
\text { Vol. V, Part } 1 \\
\text { - TIM }\end{array}$ & $\mathrm{N} / \mathrm{A}$ & $\begin{array}{l}\text { - AA } \\
\text { - ES\&HM } \\
\text { Vol. I } \\
\text { Part } 2 \\
\text { - SAR } \\
\text { - WCM }\end{array}$ & $\begin{array}{l}\text { - ES\&HM } \\
\text { Vol. I, } \\
\text { Part } 2 \\
\text { - SAR } \\
\text { - FSP } \\
\text { - OSPs } \\
\text { - WCM }\end{array}$ & $\mathrm{N} / \mathrm{A}$ \\
\hline
\end{tabular}

Table 4. Perform Work within Controls (Core Function 4) Crosswalk.

\begin{tabular}{|c|c|c|c|c|c|c|}
\hline $\begin{array}{c}\text { Line } \\
\text { Management } \\
\text { Responsibility } \\
\text { for Safety }\end{array}$ & $\begin{array}{l}\text { Clear Roles and } \\
\text { Responsibilities }\end{array}$ & $\begin{array}{c}\text { Competence } \\
\text { Commensurate } \\
\text { with } \\
\text { Responsibilities }\end{array}$ & $\begin{array}{l}\text { Balanced } \\
\text { Priorities }\end{array}$ & $\begin{array}{c}\text { Identification } \\
\text { of Safety } \\
\text { Standards } \\
\text { and } \\
\text { Requirements }\end{array}$ & $\begin{array}{l}\text { Hazard } \\
\text { Controls } \\
\text { Tailored } \\
\text { to Work } \\
\text { Being } \\
\text { Performed }\end{array}$ & $\begin{array}{l}\text { Operations } \\
\text { Authorization }\end{array}$ \\
\hline $\begin{array}{l}\text { - AA } \\
\text { - ES\&HM } \\
\text { Vol. I, Part } 2 \\
\text { - DNT Policy } \\
\text { - WCM }\end{array}$ & $\begin{array}{l}\text { - AA } \\
\text { - ES\&HM } \\
\text { Vol. I, Part } 2 \\
\text { - DNT Policy } \\
\text { - FSP, Sect. } 3 \\
\text { - OSPs } \\
\text { - WCM }\end{array}$ & $\begin{array}{l}\text { - ES\&HM } \\
\text { Vol. I, Part 2, } \\
\text { and Vol. IV, } \\
\text { Part } 2 \\
\text { - TIM }\end{array}$ & $\mathrm{N} / \mathrm{A}$ & $\mathrm{N} / \mathrm{A}$ & $\mathrm{N} / \mathrm{A}$ & $\begin{array}{l}\text { - AA } \\
\text { - ES\&HM } \\
\text { Vol. I, Part 2, } \\
\text { and Vol. V, } \\
\text { Part } 5 \\
\text { - FSP, Sect. } 2 \\
\text { - WP } \\
\text { - WCM } \\
\end{array}$ \\
\hline
\end{tabular}

Table 5. Provide Feedback and Continuous Improvement (Core Function 5)

Crosswalk.

\begin{tabular}{|c|c|c|c|c|c|c|}
\hline $\begin{array}{c}\text { Line } \\
\text { Management } \\
\text { Responsibility } \\
\text { for Safety }\end{array}$ & $\begin{array}{l}\text { Clear Roles and } \\
\text { Responsibilities }\end{array}$ & $\begin{array}{c}\text { Competence } \\
\text { Commensurate } \\
\text { with } \\
\text { Responsibilities }\end{array}$ & $\begin{array}{l}\text { Balanced } \\
\text { Priorities }\end{array}$ & $\begin{array}{l}\text { Identification } \\
\text { of Safety } \\
\text { Standards } \\
\text { and } \\
\text { Requirements }\end{array}$ & $\begin{array}{l}\text { Hazard } \\
\text { Controls } \\
\text { Tailored } \\
\text { to Work } \\
\text { Being } \\
\text { Performed }\end{array}$ & $\begin{array}{l}\text { Operations } \\
\text { Authorization }\end{array}$ \\
\hline $\begin{array}{l}\text { - AA } \\
\text { - ES\&HM } \\
\text { Vol. I, Part } 2 \\
\text { - DNT Policy } \\
\text { - SAP } \\
\text { - FIP }\end{array}$ & $\begin{array}{l}\text { - AA } \\
\text { - ES\&HM } \\
\text { Vol. I, Part 2, } \\
\text { and Vol. I, } \\
\text { Part } 5 \\
\text { - DNT Policy } \\
\text { - SAP } \\
\text { - WCM } \\
\text { - FIP }\end{array}$ & $\begin{array}{l}\text { ES\&HM } \\
\text { Vol. I, Part 2, } \\
\text { and Vol. I, } \\
\text { Part 5, and } \\
\text { Vol. IV, } \\
\text { Part 2 }\end{array}$ & $N / A$ & $\mathrm{~N} / \mathrm{A}$ & $\mathrm{N} / \mathrm{A}$ & $\mathrm{N} / \mathrm{A}$ \\
\hline
\end{tabular}




\subsection{STANDARDS AND REQUIREMENTS}

The B334 AA states: "The DNT Directorate and DOE/OAK acknowledge that the references cited in the SAR and the TSR documents as approved by DOE/OAK and any conditions of approval specified in the Safety Evaluation Report form the basis of the interim Work Smart Standards (WSS) for B334. These interim WSS will be superseded by the WSS applicable to B334 operations that will result from the reconciliation of the B334 interim WSS and the LLNL site-wide WSS." Attachment A to this Appendix is a current reconciliation between the Authorization Basis Standards and Orders and the WSS. The Superblock is in the process of evaluating and reconciling the interim WSS of the AA with the WSS approved site-wide. The final outcome, as described in Section 13.0 of the main body of this description, will be a revised AA for each Superblock facility that includes the site-wide WSS. 
This page intentionally left blank. 


\subsection{EVALUATING AND RESOLVING NON-COMPLIANCES}

After consensus between DOE/OAK and LLNL, noncompliances are acted upon at the institutional, facility, or activity level as operational priorities allow. Based on a graded approach, more serious noncompliances noted in LLNL's DefTrack system are assigned

priorities at the time of their entry into the system. See also Section 6.7 above for information on tracking and closing out noncompliances and other findings. Price-Anderson Amendments Act noncompliances are tracked through the DefTrack system irrespective of their ES\&H significance. 
This page intentionally left blank. 


\subsection{FLOWDOWN OF REQUIREMENTS}

The Superblock ISMS description lists the flowdown of requirements at the Superblock level to meet the DOE/UC Contract 48, State and local laws. This section presents this flowdown of requirements relevant to the $\mathrm{B} 334$ facility level and the corresponding B334 documentation in Table 6. In the first column, those relevant requirements to B334 are listed. The second column lists LLNL documents and others that have been developed to be in compliance with the requirements. The last column lists the B334-specific implementing documents. Attachment $\mathrm{A}$ to this Appendix is a current reconciliation between the Authorization Basis Standards and Orders and the WSS. It identifies those areas where changes in the Authorization Basis will be required.

Table 6. B334-specific documents that implement LLNL documents and DOE and other Federal regulations.

\begin{tabular}{|c|c|c|}
\hline Requirements & $\begin{array}{l}\text { Relevant LLNL documents or requirements } \\
\text { the Superblock follows }\end{array}$ & Relevant B334 documents \\
\hline $\begin{array}{l}\text { DOE Order } 420.1 \text { (Ch. 2), Facility } \\
\text { Safety }\end{array}$ & $\begin{array}{l}\text { - IIINI. FSEHM: } \\
\text {-Volume II, Part 8, "Ionizing, Non- } \\
\text { Ionizing Radiation" } \\
\text {-Volume II, Part } 10 \text { "Emergencies, } \\
\text { Earthquakes, Fire" } \\
\text { - LLNL Fire Protection Program, UCRL-MA } \\
\text { 116646 } \\
\text { - LLNL Fire Protection Engineering } \\
\text { Standards }\end{array}$ & FSP \\
\hline $\begin{array}{l}\text { DOE Order } 4330.4 \mathrm{~B}, \text { Maintenance } \\
\text { Management Program }\end{array}$ & $\begin{array}{l}\text { - LLNL Maintenance Implementation Plan for } \\
\text { Nonreactor Nuclear Facilities }\end{array}$ & WCM \\
\hline $\begin{array}{l}\text { DOE Order 5400.1, General } \\
\text { Environmental Protection Program }\end{array}$ & - LLNL ESEHM, Volume III & FSP Sect. 4 \\
\hline $\begin{array}{l}\text { DOE Order } 5480.1 \mathrm{~B}(\mathrm{Ch} .5), \\
\text { Environmental, Safety and Health } \\
\text { Program }\end{array}$ & - LLNL ESEHM & FSP \\
\hline $\begin{array}{l}\text { DOE Order } 5480.3 \text {, Safety } \\
\text { Requirements for the Packaging and } \\
\text { Transportation of Hazardous } \\
\text { Materials }\end{array}$ & $\begin{array}{l}\text { - LLNL Onsite Hazardous Materials Packaging } \\
\text { and Transportation Safety Manual }\end{array}$ & FSP Sect. 4.9 \\
\hline $\begin{array}{l}\text { DOE Order } 5480.4 \text { (Ch. 4), } \\
\text { Environmental Protection, Safety } \\
\text { and Health Protection Standards }\end{array}$ & - LLNL ESEHM & FSP \\
\hline $\begin{array}{l}\text { DOE Order } 5480.19 \text { (Ch. 1), Conduct } \\
\text { of Operations Requirements for } \\
\text { DOE Facilities }\end{array}$ & $\begin{array}{l}\text { - LLNL ESEHM, Volume 1, Part 2, "ES\&H } \\
\text { Management Requirements" }\end{array}$ & TSR; FSP; QA Plan; WCM \\
\hline $\begin{array}{l}\text { DOE Order } 5480.20 \mathrm{~A}, \text { Personnel } \\
\text { Selection, Qualification, and } \\
\text { Training Requircments for DOE } \\
\text { Nuclear Facilities }\end{array}$ & $\begin{array}{l}\text { - LLNL ESEHM: } \\
\text {-Volume 1, Part 2, "ES\&H Management } \\
\text { Requirements" } \\
\text {-Volume V, Part 1, "Personnel" } \\
\text { - LLNL Defense Systems/Nuclear Design } \\
\text { Directorate Training Plan }\end{array}$ & $\begin{array}{c}\text { FSP Sect. 5; TIM } \\
\end{array}$ \\
\hline $\begin{array}{l}\text { DOE Order 5480.21, Unreviewed } \\
\text { Safety Questions }\end{array}$ & $\begin{array}{l}\text { - LLNL ES\&HM: } \\
\text {-Volume 1, Part 2, "ES\&H Management } \\
\text { Requirements" } \\
\text {-Volume V, Part 2, "Procedures" }\end{array}$ & WCM \\
\hline
\end{tabular}

(table continued next page) 
Table 6. B334-specific documents that implement LLNL documents and DOE and other Federal regulations. (continued)

\begin{tabular}{|c|c|c|}
\hline Requirements & $\begin{array}{l}\text { Relevant LLNL documents or requirements } \\
\text { the Superblock follows }\end{array}$ & Relevant B334 documents \\
\hline $\begin{array}{l}\text { DOE Order } 5480.22 \text { (Ch. 1), } \\
\text { Technical Safety Requirements }\end{array}$ & $\begin{array}{l}\text { - LLNL ESEHM: } \\
\text {-Volume 1, Part 2, "ES\&H Management } \\
\text { Requirements" } \\
\text {-Volume V, Part 2, "Procedures" }\end{array}$ & TSR \\
\hline $\begin{array}{l}\text { DOE Order } 5480.23 \text { (Ch. 1), Nuclear } \\
\text { Safety Analysis Report }\end{array}$ & $\begin{array}{l}\text { - LLNL ESEHM: } \\
\text { —Volume 1, Part 2, "ES\&H Management } \\
\text { Requirements" } \\
\text {-Volume V, Part 2, "Procedures" } \\
\text { - DOE-STD-3009, Preparation Guide for U.S. } \\
\text { DOE Nonreactor Nuclear Facility Safety } \\
\text { Analysis Reports, draft, 4/94 } \\
\text { - DOE-STD-1027, Guidance on Preliminary } \\
\text { Hazard Classification and Accident Analysis } \\
\text { Techniques for Compliance with DOE } \\
\text { 5430.23 Nuclear Safety Analysis Report } \\
\text { - DOE-STD-1104, Guidance on Preliminary } \\
\text { Hazard Classification and Accident Review } \\
\text { and Approval of Nonreactor Nuclear Facility } \\
\text { Safety Analysis Report }\end{array}$ & Authorization Agreement \\
\hline $\begin{array}{l}\text { DOE Order } 5480.31 \text {, Startup and } \\
\text { Restart of Nuclear Facilities }\end{array}$ & $\begin{array}{l}\text { - LLNL ESEHM: } \\
\text {-Volume 1, Part 2, "ES\&H Management } \\
\text { Requirements" } \\
\text {-Volume V, Part 5, "Facilities" }\end{array}$ & $\overline{F S P}$ \\
\hline $\begin{array}{l}\text { DOE Order 5484.1, Environmental } \\
\text { Protection, Safety, and Health } \\
\text { Prutection Information Reporting } \\
\text { Requirements }\end{array}$ & $\begin{array}{l}\text { - LLNL ESEHM: } \\
\text {-Volume I, Part 5, "Feedback and } \\
\text { Improvement" } \\
\text {-Volume II, Part 10, Emergencies, } \\
\text { Earthquakes, Fire" }\end{array}$ & FSP Sect. 3 \\
\hline $\begin{array}{l}\text { DOE Order 5820.2A, Radioactive } \\
\text { Waste Management }\end{array}$ & $\begin{array}{l}\text { - LLNL Waste Acceptance Criteria } \\
\text { - LLNI. TRU Waste Program Certification and } \\
\text { Quality Assurance Plan } \\
\text { - LLNL Low-Level Waste Program Certification } \\
\text { and Quality Assurance Plan } \\
\text { - LLNL Guidelines for Waste Accumulation } \\
\text { Area } \\
\text { - Defense \& Nuclear Technologies Directorate } \\
\text { Waste Minimization and Pollution Prevention } \\
\text { Plan }\end{array}$ & FSP \\
\hline $\begin{array}{l}10 \text { CFR } 830.120 \text { Quality Assurance } \\
\text { DOE Order } 5700.6 \mathrm{C}, \text { Quality } \\
\text { Assurance }\end{array}$ & $\begin{array}{l}\text { Quality Assurance Plan for Nuclear } \\
\text { Facilities, Rev. 4, and LLNL [PAAA] } \\
\text { Implementation Plan, Rev. 4. }\end{array}$ & QA Plan \\
\hline $\begin{array}{l}\text { 10 CFR 835: Occupational Radiation } \\
\text { Protection } \\
\text { DOE Order 5400.5 (Ch. 2), Radiation } \\
\text { Protection of the I'ublic and the } \\
\text { Environment }\end{array}$ & $\begin{array}{l}\text { - LLNL ESEHM } \\
\text { - Volume II, Part 8, "Ionizing, Non- } \\
\text { Ionizing Radiation" } \\
\text {-Volume II, Part 10, "Emergencies, } \\
\text { Earthquakes, Fire" }\end{array}$ & FSP; OSPS \\
\hline
\end{tabular}

Based on the above table, a simplified representation of the hierarchy of LLNL/B334 documents is presented in Figure 2 on the following page. 


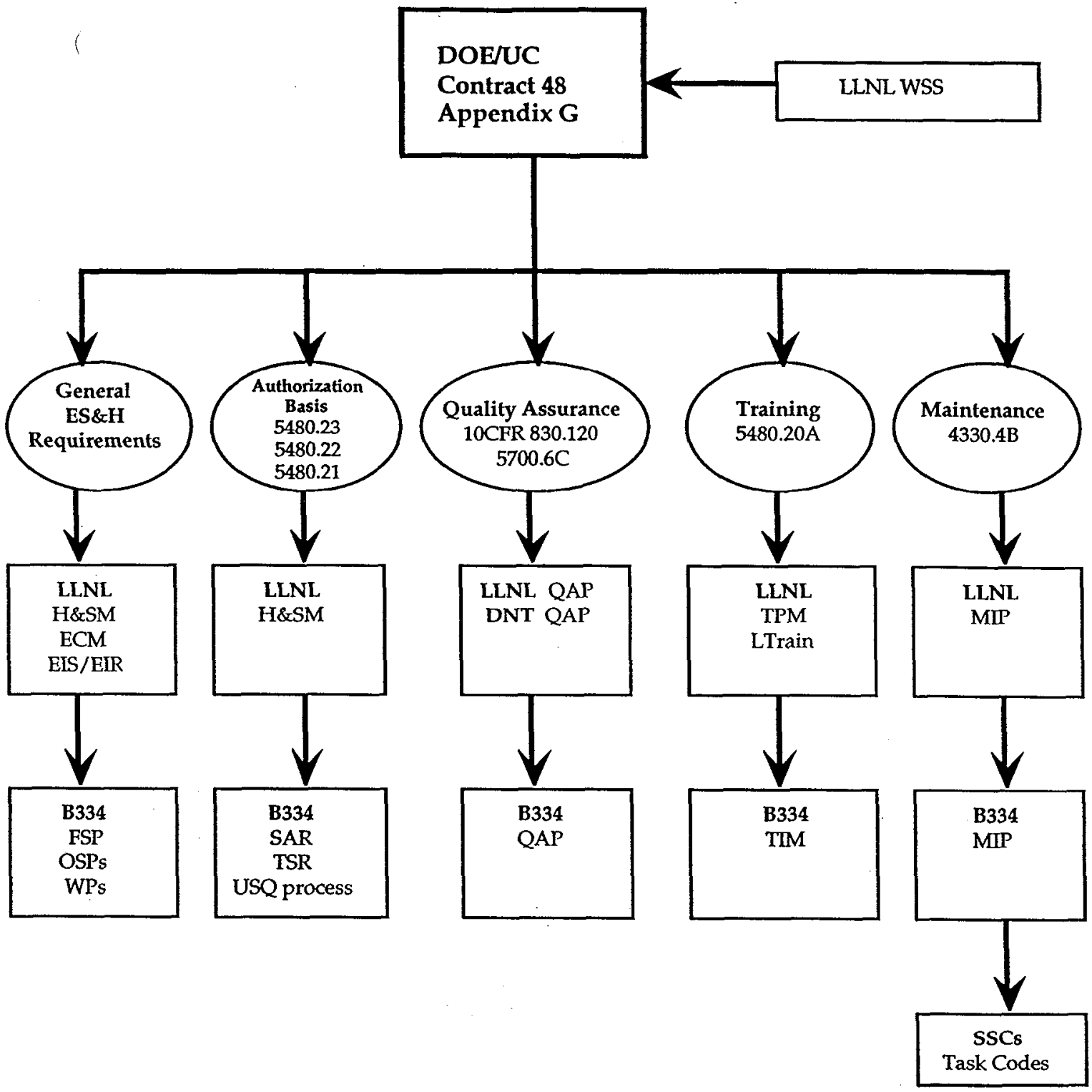

\section{Legend}

EIS/EIR: Environmental Impact Statement/Environmental Impact Report

ES\&HM LLNL Environmental, Safety and Health Manual

FSP: $\quad$ Facility Safety Plan

LTRAIN: Livermore Training Records and Information Network

MIP: $\quad$ Maintenance Implementation Plan

OSPs: Operational Safety Plans

QAP: $\quad$ Quality Assurance Plan

SAR: $\quad$ Safety Analysis Report

SSCs Structures, Systems, and Components

TIM: $\quad$ Training Implementation Matrix

TPM: $\quad$ Training Program Manual

TSR: $\quad$ Technical Safety Requirement

USQ: $\quad$ Unreviewed Safety Question

WPs: Work Permits

Figure 2. Simplified LLNL/B334 ES\&H document tree. 
This page intentionally left blank. 


\subsection{IMPLEMENTATION TASKS, SCHEDULE, AND MILESTONES}

Consistent with Section 14.0 of the Superblock ISMS Description, the following tasks, schedule, and milestones have been established for B334:

- Complete corrective actions for B334 ISMSV. (December 1999)

- Performance Measures implemented. (December 1999

- Reconciliation of Site-wide ISMS and B334 ISMS. (Superblock Management will provide reconciliation plan within three months after Site-wide Phase II Verification.)

- Reconciliation of LLNL WSS and B334 interim WSS. (June 2000) 
This page intentionally left blank. 
ATTACHMENT A

\section{BUILDING 334 WORK SMART STANDARDS RECONCILIATION}

\begin{tabular}{|c|c|c|c|c|}
\hline B334 SAR Basis & $\begin{array}{l}\text { Current } \\
\text { Status of } \\
\text { Each } \\
\text { Order, } \\
\text { Standard, } \\
\text { etc. }\end{array}$ & $\begin{array}{l}\text { If Order, } \\
\text { Standard, } \\
\text { etc., } \\
\text { Cancelled or } \\
\text { Superseded, } \\
\text { Replaced by }\end{array}$ & $\begin{array}{l}\text { Latest } \\
\text { Version In } \\
\text { LLNL } \\
\text { Contract/ } \\
\text { WSS? }\end{array}$ & $\begin{array}{l}\text { Auth. Basis } \\
\text { Change? } \\
\text { Yes/No }\end{array}$ \\
\hline $\begin{array}{l}\text { DOE Order 1540.2, Hazardous Material Packaging for } \\
\text { Transport-Administrative Procedures (December 1988) }\end{array}$ & $\begin{array}{l}\text { Cancelled } \\
\text { by DOE }\end{array}$ & $\mathrm{O} 460.1 \mathrm{~A}$ & Yes & Yes \\
\hline $\begin{array}{l}\text { DOE Order 4330.4B, Maintenance Management Program } \\
\text { (May 1992) }\end{array}$ & $\begin{array}{l}\text { Still } \\
\text { Current }\end{array}$ & & Yes & No \\
\hline $\begin{array}{l}\text { DOE Order 4700.1, Project Management System (March } \\
\text { 1987) }\end{array}$ & Superseded & $\mathrm{O} 430.1 \mathrm{~A}$ & Yes & Yes \\
\hline $\begin{array}{l}\text { DOE Order 5000.3B, Ch. 1, Occurrence Reporting and } \\
\text { Processing Operations Information (July 1993) }\end{array}$ & Superseded & O 232.1A & Yes & Yes \\
\hline $\begin{array}{l}\text { DOE Order 5400.1, General Environmental Protection } \\
\text { Program (June 1990) }\end{array}$ & $\begin{array}{l}\text { Partially } \\
\text { Cancelled } \\
\text { by DOE }\end{array}$ & O 232.1A & Yes & Yes \\
\hline $\begin{array}{l}\text { DOE Order 5400.3A, Hazardous and Radioactive Mixed } \\
\text { Waste Program (February 1989) }\end{array}$ & $\begin{array}{l}\text { Cancelled } \\
\text { by DOE }\end{array}$ & O 5820.2A & Yes & No \\
\hline $\begin{array}{l}\text { DOE Order 5400.4, Comprehensive Environmental } \\
\text { Response Compensation Liability Act Requirements }\end{array}$ & $\begin{array}{l}\text { Cancelled } \\
\text { by DOE }\end{array}$ & O 251.6 & No & No \\
\hline $\begin{array}{l}\text { DOE Order 5400.5, Radiation Protection of the Public and } \\
\text { the Environment (Ch. 2, January 1993) }\end{array}$ & $\begin{array}{l}\text { Partially } \\
\text { Cancelled } \\
\text { by DOE }\end{array}$ & O 232.1A & Yes & Yes \\
\hline $\begin{array}{l}\text { DOE Order 5440.1E, National Environmental Policy Act } \\
\text { Compliance Programs (November 1992) }\end{array}$ & $\begin{array}{l}\text { Cancelled } \\
\text { by DOE }\end{array}$ & O 231.1 & Yes & Yes \\
\hline $\begin{array}{l}\text { DOE Order 5480.1B, Environmental, Safety, and Health } \\
\text { Program (Ch. 5, May 1993) }\end{array}$ & $\begin{array}{l}\text { Cancelled } \\
\text { by DOE }\end{array}$ & O 251.4 & No & No \\
\hline $\begin{array}{l}\text { DOE Order } 5480.3, \text { Safety Requirements for the Packaging } \\
\text { and Transportation of Hazardous Materials, Hazardous } \\
\text { Substances, and Hazardous Wastes (July 1985) }\end{array}$ & $\begin{array}{l}\text { Cancelled } \\
\text { by DOE }\end{array}$ & $\mathrm{O} 460.1 \mathrm{~A}$ & No & No \\
\hline $\begin{array}{l}\text { DOE Order 5480.4, Environmental Protection, Safety and } \\
\text { Health Protection Standards (Ch. 4, December 1998) } \\
\text { [Note: Per O 440.1, cancel Attach 2, para 2c, 2d(2)-(3), } \\
\text { 2e(1)-(8), and Attach 3, para 2c, 2d(2)-(3) and 2e(1)-(7)] }\end{array}$ & $\begin{array}{l}\text { Partially } \\
\text { Cancelled } \\
\text { by DOE }\end{array}$ & $\mathrm{O} 440.1 \mathrm{~A}$ & Yes & Yes \\
\hline DOE Order 5480.7A, Fire Protection (February 1993) & $\begin{array}{l}\text { Cancelled } \\
\text { by DOE }\end{array}$ & $\begin{array}{l}\text { Part O } 420.1 \\
\text { Part } 440.1 \mathrm{~A}\end{array}$ & $\begin{array}{l}\text { Yes } \\
\text { Yes }\end{array}$ & $\begin{array}{l}\text { Yes } \\
\text { Yes }\end{array}$ \\
\hline $\begin{array}{l}\text { DOE Order 5480.8A, Ch. 1, Contractor Occupational } \\
\text { Medical Program (October 1992) }\end{array}$ & $\begin{array}{l}\text { Cancelled } \\
\text { by DOE }\end{array}$ & $\mathrm{O} 440.1 \mathrm{~A}$ & Yes & Yes \\
\hline $\begin{array}{l}\text { DOE Order 5480.9, Construction Safety and Health } \\
\text { Program (November 1987) }\end{array}$ & $\begin{array}{l}\text { Cancelled } \\
\text { by DOE }\end{array}$ & $\mathrm{O} 440.1 \mathrm{~A}$ & Yes & Yes \\
\hline
\end{tabular}




\begin{tabular}{|c|c|c|c|c|}
\hline $\begin{array}{l}\text { DOE Order 5480.10, Contractor Industrial Hygiene } \\
\text { Program (June 1985) }\end{array}$ & $\begin{array}{l}\text { Cancelled } \\
\text { by DOE }\end{array}$ & $\mathrm{O} 440.1 \mathrm{~A}$ & Yes & Yes \\
\hline $\begin{array}{l}\text { DOE Order 5480.19, Conduct of Operations Requirements } \\
\text { for DOE Facilities (May 1992) }\end{array}$ & $\begin{array}{l}\text { Still } \\
\text { Current }\end{array}$ & $\begin{array}{l}\text { O } 5480.19 \\
\text { Ch. } 1\end{array}$ & Yes & Yes \\
\hline $\begin{array}{l}\text { DOE Order 5480.21, Unreviewed Safety Questions } \\
\text { (November 1992) }\end{array}$ & $\begin{array}{l}\text { Still } \\
\text { Current }\end{array}$ & & Yes & No \\
\hline $\begin{array}{l}\text { DOE Order 5480.23, Nuclear Safety Analysis Reports } \\
\text { (Ch. 1, April 1992) }\end{array}$ & Superseded & $\begin{array}{l}\text { O } 5480.3 \\
\text { Ch. } 1\end{array}$ & Yes & Yes \\
\hline $\begin{array}{l}\text { DOE Order 5480.30, Nuclear Reactor Safety Design } \\
\text { Criteria (January 1993) }\end{array}$ & $\begin{array}{l}\text { Still } \\
\text { Current }\end{array}$ & & No & No \\
\hline $\begin{array}{l}\text { DOE Order 5481.1B, Safety Analysis and Review } \\
\text { (May 1987) }\end{array}$ & $\begin{array}{l}\text { Cancelled } \\
\text { by DOE }\end{array}$ & $\begin{array}{l}\text { Repl by SAN } \\
\text { MD } 5481.1 \mathrm{~A}\end{array}$ & Yes & Yes \\
\hline $\begin{array}{l}\text { DOE Order 5482.1B, Environment, Safety, and Health } \\
\text { Appraisal Program (November 1992) }\end{array}$ & $\begin{array}{l}\text { Cancelled } \\
\text { by DOE }\end{array}$ & & No & No \\
\hline $\begin{array}{l}\text { DOE Order 5483.1A, Occupational Safety and Health } \\
\text { Program for DOE Contractor Employees at Government- } \\
\text { Owned, Contractor-Operated Facilities (June 1983) }\end{array}$ & $\begin{array}{l}\text { Cancelled } \\
\text { by DOE }\end{array}$ & $\mathrm{O} 440.1 \mathrm{~A}$ & Yes & Yes \\
\hline $\begin{array}{l}\text { DOE Order 5484.1, Environmental Protection, Safety, and } \\
\text { Health Protection Information Reporting Requirements } \\
\text { (October 1990) }\end{array}$ & $\begin{array}{l}\text { Cancelled } \\
\text { by DOE }\end{array}$ & O 231.1 Ch. 2 & Yes & Yes \\
\hline $\begin{array}{l}\text { DOE Order 5500.1B, Emergency Management System } \\
\text { (February 1992) }\end{array}$ & $\begin{array}{l}\text { Cancelled } \\
\text { by DOE }\end{array}$ & O $151.1 \mathrm{Ch} .2$ & Yes & Yes \\
\hline $\begin{array}{l}\text { DOE Order 5500.2B, Emergency Categories, Classes, and } \\
\text { Notification and Reporting Requirements (February 1992) }\end{array}$ & $\begin{array}{l}\text { Cancelled } \\
\text { by DOE }\end{array}$ & O $151.1 \mathrm{Ch} .2$ & Yes & Yes \\
\hline $\begin{array}{l}\text { DOE Order 5500.3A, Planning and Preparedness for } \\
\text { Operational Emergencies (February 1992) }\end{array}$ & $\begin{array}{l}\text { Cancelled } \\
\text { by DOE }\end{array}$ & O $151.1 \mathrm{Ch} .2$ & Yes & Yes \\
\hline $\begin{array}{l}\text { DOE Order 5500.4A, Public Affairs Policy and Planning } \\
\text { Requirements for Emergencies (June 1992) }\end{array}$ & $\begin{array}{l}\text { Cancelled } \\
\text { by DOE }\end{array}$ & O $151.1 \mathrm{Ch} .2$ & Yes & Yes \\
\hline $\begin{array}{l}\text { DOE Order 5500.9A, Emergency Planning, Preparedness, } \\
\text { and Response to Continuity of Government Emergencies } \\
\text { (July 1992) }\end{array}$ & $\begin{array}{l}\text { Cancelled } \\
\text { by DOE }\end{array}$ & O $151.1 \mathrm{Ch} .2$ & Yes & Yes \\
\hline $\begin{array}{l}\text { DOE Order 5500.10, Emergency Readiness Assurance } \\
\text { Program (February 1992) }\end{array}$ & $\begin{array}{l}\text { Cancelled } \\
\text { by DOE }\end{array}$ & O $151.1 \mathrm{Ch} .2$ & Yes & Yes \\
\hline $\begin{array}{l}\text { DOE Order 5530.3, Radiological Assistance Program } \\
\text { (January 1992) }\end{array}$ & $\begin{array}{l}\text { Still } \\
\text { Current }\end{array}$ & & Yes & No \\
\hline $\begin{array}{l}\text { DOE Order 5530.5, Ch. 1, Federal Radiological and } \\
\text { Monitoring Assessment Center (December 1992) }\end{array}$ & $\begin{array}{l}\text { Still } \\
\text { Current }\end{array}$ & & Yes & No \\
\hline $\begin{array}{l}\text { DOE Order 5633.3A, Control and Accountability of } \\
\text { Nuclear Material (February 1993) }\end{array}$ & Superseded & O $474.18 / 99$ & Yes & Yes \\
\hline DOE Order 5700.6C, Quality Assurance (August 1991) & $\begin{array}{l}\text { Same as } \\
10 \text { CFR } \\
830.120 \& \\
0414.1\end{array}$ & $\begin{array}{l}\text { 10 CFR } \\
830.120\end{array}$ & Yes & Yes \\
\hline $\begin{array}{l}\text { DOE Order 6430.1A, General Design Criteria (April 1989) } \\
\text { (Will be rewritten into DOE MD.) }\end{array}$ & $\begin{array}{l}\text { Cancelled } \\
\text { except for } \\
\text { DNFSB } \\
\text { Facilities }\end{array}$ & & No & No \\
\hline $\begin{array}{l}\text { DOE Order N5400.12, Extension of DOE O N5400.9, } \\
\text { Sealed Radioactive Source Accountability (December } \\
\text { 1993) }\end{array}$ & $\begin{array}{l}\text { Expired } \\
12 / 95\end{array}$ & & No & No \\
\hline
\end{tabular}


Appendix C: B334 ISMS

\begin{tabular}{|c|c|c|c|c|}
\hline $\begin{array}{l}\text { DOE Order 5480.8, Radiological Health and Safety Policy } \\
\text { (June 1993) }\end{array}$ & Superseded & O 251.4 & No & No \\
\hline $\begin{array}{l}\text { DOE Order N5480.10, Extension of N5480.6, Radiological } \\
\text { Control Manual (July 1994) }\end{array}$ & Superseded & O 251.4 & No & No \\
\hline \multicolumn{5}{|l|}{ DOE Standards \& Guidance } \\
\hline $\begin{array}{l}\text { DOE-STD-1020-94, "Natural Phenomena Hazards and } \\
\text { Evaluation Criteria for DOE Facilities" (April 1994) }\end{array}$ & Superseded & $\begin{array}{l}\text { STD } 1020-94 \\
\text { Ch .1 }\end{array}$ & Yes & Yes \\
\hline $\begin{array}{l}\text { DOE-STD-1027-92 Chg. } 1 \text { Hazard Categorization and } \\
\text { Accident Analysis Techniques for Compliance with DOE } \\
\text { Order 5480.23, Nuclear Safety Analysis Reports } 1992\end{array}$ & $\begin{array}{l}\text { Still } \\
\text { Current }\end{array}$ & & Yes & No \\
\hline $\begin{array}{l}\text { DOE-STD-3009-94, Draft, Preparation Guide for U.S. } \\
\text { Department of Energy Nonreactor Nuclear Facility Safety } \\
\text { Analysis Reports (March 1994) }\end{array}$ & Superseded & STD-3009-95 & No & No \\
\hline $\begin{array}{l}\text { DOE/TP20-11, General Fire Fighting Guidance for } \\
\text { Nuclear Weapons }\end{array}$ & $\begin{array}{l}\text { Still } \\
\text { Current }\end{array}$ & & No & No \\
\hline
\end{tabular}

Federal Codes, Standards, and Regulations

\begin{tabular}{|l|c|c|c|}
\hline 10 CFR 71, Packaging of Radioactive Materials for Transport & $\begin{array}{c}\text { Still } \\
\text { Current }\end{array}$ & Yes & No \\
\hline 10 CFR 830.120, Quality Assurance & $\begin{array}{c}\text { Still } \\
\text { Current }\end{array}$ & Yes & No \\
\hline 10 CFR 835, Radiation Protection for Occupational Workers & $\begin{array}{c}\text { Still } \\
\text { Current }\end{array}$ & Yes & No \\
\hline 29 CFR 1910, OSHA Standards & $\begin{array}{c}\text { Still } \\
\text { Current }\end{array}$ & Yes & No \\
\hline $\begin{array}{l}\text { 29 CFR 1960, Safety and Health Provisions for Federal } \\
\text { Employees }\end{array}$ & & No & No \\
\hline 40 CFR 302.4, Environmental Protection Agency & $\begin{array}{c}\text { Still } \\
\text { Current }\end{array}$ & & No \\
\hline $\begin{array}{l}\text { 49 CFR 100-199, Department of Transportation Hazardous } \\
\text { Materials Regulations (DOT) }\end{array}$ & Yurrent & & No \\
\hline 49 CFR 397, Hazardous Materials Regulations (DOT) & & No & No \\
\hline
\end{tabular}

National Codes, Standards \& Guides

\begin{tabular}{|c|c|c|c|}
\hline National Fire Codes (NFPA) & $\begin{array}{l}\text { Still } \\
\text { Current }\end{array}$ & Yes & No \\
\hline National Electrical Code (NFPA 70) & $\begin{array}{l}\text { Still } \\
\text { Current }\end{array}$ & Yes & No \\
\hline ASME Boiler and Pressure Vessel Code & $\begin{array}{l}\text { Still } \\
\text { Current }\end{array}$ & Yes & No \\
\hline ANSI Z88.2, Practices for Respiratory Protection, 1980 & $\begin{array}{l}\text { Still } \\
\text { Current }\end{array}$ & Yes J & No \\
\hline $\begin{array}{l}\text { ANSI/ANS 8.15, Nuclear Criticality Control of Special } \\
\text { Actinide Elements, } 1981\end{array}$ & $\begin{array}{l}\text { Still } \\
\text { Current }\end{array}$ & No & No \\
\hline $\begin{array}{l}\text { ANSI/ANS 8.19, Administrative Practices for Nuclear } \\
\text { Criticality Safety, } 1984\end{array}$ & $\begin{array}{l}\text { Still } \\
\text { Current }\end{array}$ & No & No \\
\hline ANSI B30, Crane Safety & $\begin{array}{l}\text { Still } \\
\text { Current }\end{array}$ & No & No \\
\hline
\end{tabular}




\begin{tabular}{|c|c|c|c|}
\hline ANSI C2, National Electrical Safety Code, 1993 & $\begin{array}{l}\text { Still } \\
\text { Current }\end{array}$ & No & No \\
\hline $\begin{array}{l}\text { ANSI N 13.5, Performance Specifications for Direct Reading } \\
\text { and Indirect Reading Pocket Dosimeters for X and Gamma } \\
\text { Radiation, } 1972\end{array}$ & $\begin{array}{l}\text { Still } \\
\text { Current }\end{array}$ & No & No \\
\hline $\begin{array}{l}\text { ANSI N 322, Inspection and Test Specifications for Direct and } \\
\text { Indirect Reading Quartz Fiber Pocket Dosimeters, } 1975\end{array}$ & $\begin{array}{l}\text { Still } \\
\text { Current }\end{array}$ & No & No \\
\hline $\begin{array}{l}\text { ANSI N 323, Radiation Protection Instrumentation Test and } \\
\text { Calibration, } 1978\end{array}$ & $\begin{array}{l}\text { Still } \\
\text { Current }\end{array}$ & No & No \\
\hline $\begin{array}{l}\text { CMAA, Crane Manufacturers Association of America, } \\
\text { Specification No. } 70\end{array}$ & $\begin{array}{l}\text { Still } \\
\text { Current }\end{array}$ & No & No \\
\hline $\begin{array}{l}\text { FM, Factory Mutual Approval Guide (FM Data Sheet 7-98, } \\
\text { Hyd Fluids) }\end{array}$ & $\begin{array}{l}\text { Still } \\
\text { Current }\end{array}$ & Yes & No \\
\hline UL, Product Directories of Underwriters Laboratories & $\begin{array}{l}\text { Still } \\
\text { Current }\end{array}$ & No & No \\
\hline \multicolumn{4}{|l|}{ State \& Local Codes } \\
\hline $\begin{array}{l}\text { California Hazardous Waste Control Law, Health and } \\
\text { Safety Code, Chapter } 6.5 \text { (Misc. Articles in WSS) }\end{array}$ & $\begin{array}{l}\text { Still } \\
\text { Current }\end{array}$ & Yes & No \\
\hline $\begin{array}{l}\text { Title } 22 \text { of the California Code of Regulations (latest } \\
\text { revision) (Misc. Articles in WSS) }\end{array}$ & $\begin{array}{l}\text { Still } \\
\text { Current }\end{array}$ & Yes & No \\
\hline $\begin{array}{l}\text { City of Livermore Municipal Code, Chapter 13.32, "Waste } \\
\text { Water Collection and Treatment System" }\end{array}$ & $\begin{array}{l}\text { Still } \\
\text { Current }\end{array}$ & Yes & No \\
\hline \multicolumn{4}{|l|}{ Other Guides \& References } \\
\hline $\begin{array}{l}\text { ACGIH, "TLVs-Threshold Limit Values for Chemical } \\
\text { Substances and Physical Agents in the Workroom } \\
\text { Environment with Intended Changes" (latest edition) }\end{array}$ & $\begin{array}{l}\text { Still } \\
\text { Current }\end{array}$ & Yes & No \\
\hline $\begin{array}{l}\text { IAEA, Regulations for the Safe Transport of Radioactive } \\
\text { Material, Safety Series No. } 6\end{array}$ & $\begin{array}{l}\text { Still } \\
\text { Current }\end{array}$ & No & No \\
\hline
\end{tabular}

